\title{
Compositional and functional shifts in belowground fungal communities in tropical land-use systems
}

\author{
Dissertation \\ for the award of the degree \\ “Doctor rerum naturalium" (Dr. rer. nat.) \\ of the Georg-August-Universität Göttingen
}

within the doctoral program „Grundprogramm Biologie“

of the Georg-August University School of Science (GAUSS)

submitted by

Johannes Ballauff

born in Marburg

Göttingen, 2020 


\section{Thesis Committee}

Prof. Dr. Andrea Polle (Forest Botany and Tree Physiology, Büsgen-Institute)

Prof. Dr. Stefan Scheu (Animal Ecology, J.F. Blumenbach Institute of Zoology and Anthropology)

Members of the Examination Board

Reviewer: Prof. Dr. Andrea Polle (Forest Botany and Tree Physiology, Büsgen-Institute)

Second Reviewer: Prof. Dr. Stefan Scheu (Animal Ecology, J.F. Blumenbach Institute of Zoology and Anthropology)

Further members of the Examination Board:

Prof. Dr. Rolf Daniel (Genomic and Applied Microbiology, Institute of Microbiology and Genetics)

Prof. Dr. Oliver Gailing (Forest Genetics and Forest Tree Breeding, Büsgen-Institute)

Prof. Dr. Christian Ammer (Silviculture and Forest Ecology of the Temperate Zones)

Prof. Dr. Christoph Leuschner (Plant Ecology and Ecosystem Research, Albrecht-von-Haller-Institute for Plant Sciences)

Date of the oral examiniation: 09.06.2020 


\section{Table of Contents}

Summary

1 General Introduction. 1

1.1 Land conversion of tropical rainforests in South East Asia ............................... 1

1.2 The root-fungal continuum ............................................................................. 5

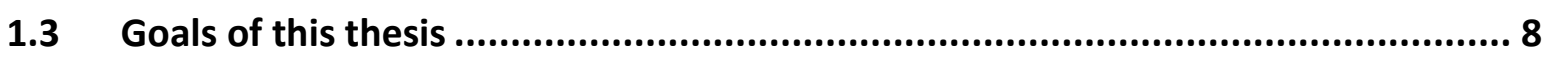

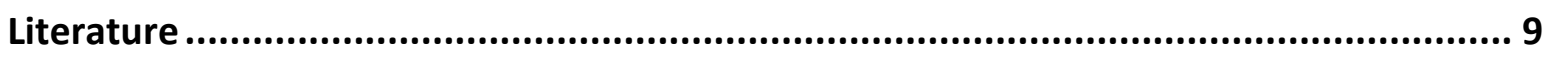

2 Research Chapters ................................................ 15

2.1 Land-use intensity drives diversity, abundance and community composition of arbuscular mycorrhizal fungi across tropical land-use systems ................................... 15

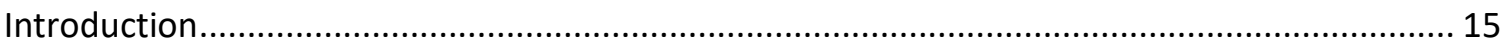

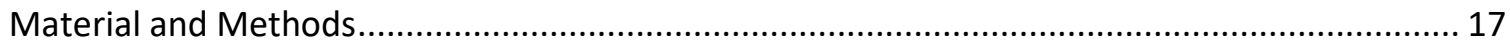

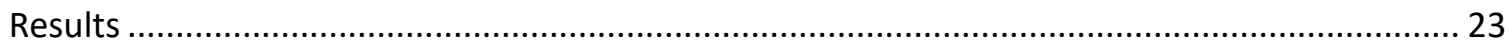

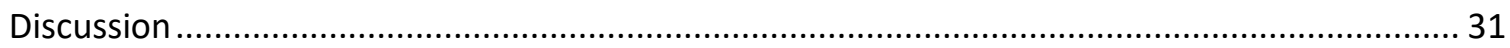

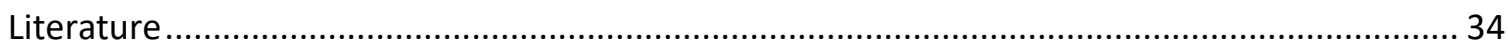

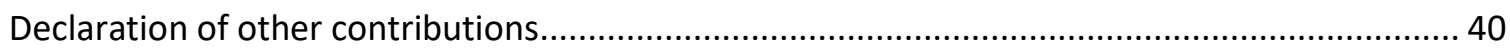

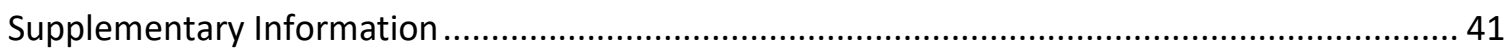

2.2 Bottom-up effects of roots on belowground fungal communities in tropical land-

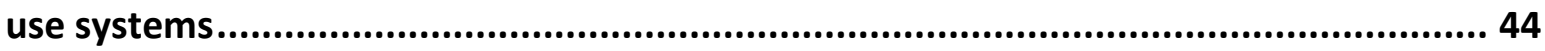

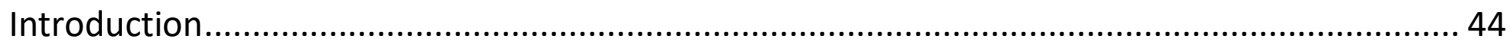

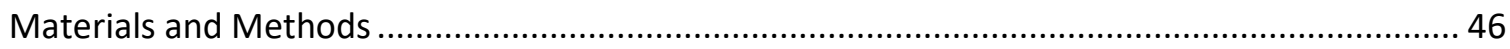

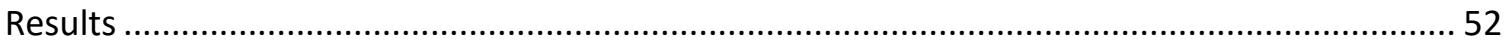

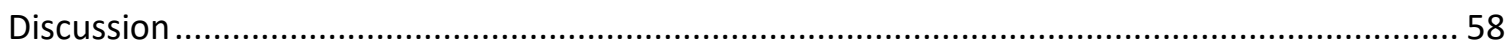

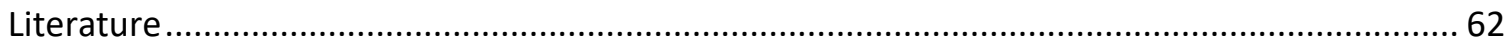

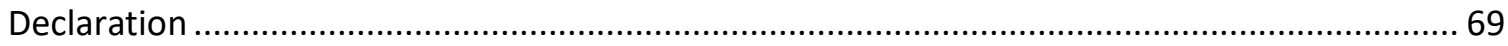

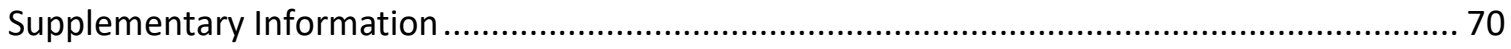

2.3 Soil conditions and stochasticity, not tree diversity drive the soil fungal community in a newly-established biodiversity enriched oil palm plantation .............. 75

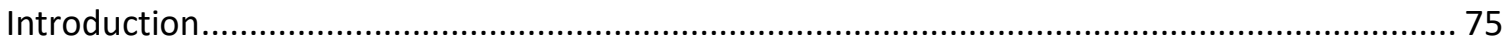

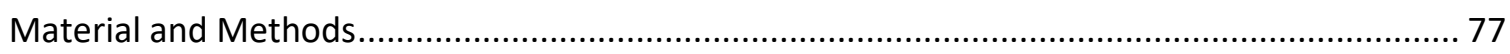

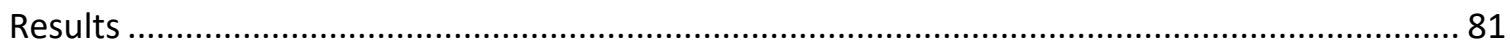

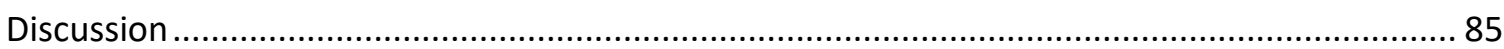

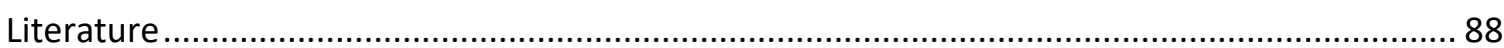

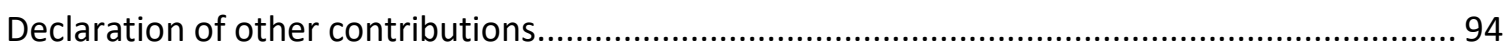

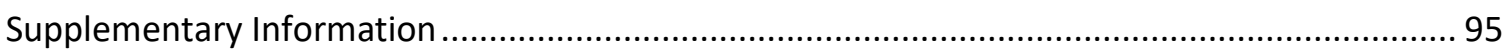

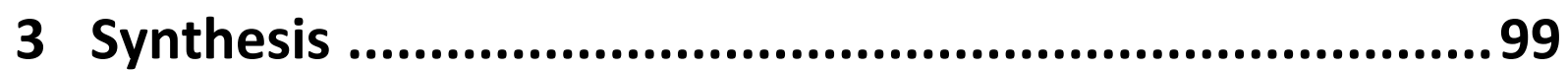

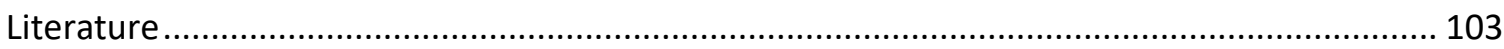


Acknowledgements.

Appendix 1: Sampling and export Permission.

Appendix 2: Intensive tropical land use massively shifts soil fungal communities .108

Eidestattliche Erklärung .138

Curriculum Vitae .139 


\section{Summary}

Tropical low-land rainforests are one of the most diverse ecosystems in the world and provide valuable ecosystem services such as climate change mitigation. They are immensely threatened by expanding human land-use. Especially in South-East Asia, deforestation and replacement with cash crop monoculture plantations such as rubber (Hevea brasiliensis) and oil palm (Elaeis guineensis) have led to drastic losses in biodiversity and to ecosystem degradation. Recently, the research focus has increasingly extended to belowground demonstrating strong structuring effects of human landuse on soil microbial communities. Fungi fulfill various ecological functions and their interaction with plants include efficient degradation of dead plant material (saprotrophs), mutualistic mycorrhizal interactions with roots, essential for the nutrient uptake in a majority of land plants, and structuring effects on plant communities (pathogens). Thereby, fungi are often tightly associated with the plant community as a key group of organisms facilitating the flow of nutrients between the below- and aboveground biome. Conversion of tropical lowland rainforests plantations leads to drastic changes in fungal community structures. The magnitude of structuring effects by changes in root or soil properties on the composition of trophic groups (mycorrhiza, saprotrophs and pathogens) remains unknown. The present thesis, conducted on Sumatra (Indonesia), analyses the structuring effects of human land-use in tropical ecosystems on this important group of microorganisms using next generation sequencing methods and root and soil properties. The work is structured into three major research chapters.

In the first research chapter, I analyzed the effect of land-use intensity on root associated arbuscular mycorrhizal fungi (AM). Anthropogenic land-use severely affects the AM communities in grasslands but tropical forest transformation systems have rarely been studied. I hypothesized that increased land-use intensities negatively affect AM abundance and diversity because of impaired plant fungus interactions at the roots. I further hypothesized that increases in land-use intensity drive the composition of the AM community, causing decline in naturally occurring AM fungi. A land-use intensity index (LUI) based on yield, chemical input and plant richness across four major land-use systems (forest, jungle rubber, rubber and oil palm plantations) was developed and the effect of LUI on AM molecular richness and abundance as well as AM spore abundance and root colonization was tested. Indicator species analysis was used to investigate significant associations between AM species and land-use types. LUI structured the root associated AM community and negatively affected AM diversity and abundance but positively affected AM spore abundance in soil. Distinct land-use types harbored distinct AM communities; however, forest harbored a higher number of indicator species. In conclusion, land-use intensity strongly altered AM communities across land-use systems reducing 
specialized OTUs. Extensive management practices may help sustain a diverse and abundant AM community.

Local soil and root associated fungal communities often differ considerably. Likely, this is caused by varying magnitude of structuring effects by the plant root community (biotic environmental filter) and edaphic conditions (abiotic environmental filter). However, few studies analyzed the effects of those environmental drivers on root versus soil associated fungal communities across different landuse types. In chapter 2, I tested the hypothesis that root associated fungi respond to changes in root properties more strongly than to changes in soil properties, due to their strong dependence on the root community. In turn, the soil fungal community provides a species pool from which the root community is recruited and this pool is structured mainly by changes in soil properties and stochastic fluctuations. Shifts of different ecological groups of soil and root inhabiting fungi in response to spatial distance as well as changes in soil and root chemistry across different land-use systems (as above, including riparian sites) were investigated. Overall, environmental filters had a stronger effect on the fungal community composition than geographic distance. Unexpectedly, high turnover and low nestedness between local root and soil communities was found. Additionally to a strong structuring effect of soil $\mathrm{pH}$, root chemistry, especially root $\mathrm{C} / \mathrm{N}$ strongly affected the composition of the root-associated fungal assemblages, while root vitality also affected shifts in soil-residing fungal communities. Root and soil chemistry changes drove divergent turnover of different functional groups (saprotroph, mycorrhiza and plant pathoges) in soil and roots. An important novel result was that assemblages root associated fungal communities were promoted by changes of root chemistry largely independent of the surrounding soil community. Therefore, recovering chemical root traits in intensively managed systems may stabilize the fungal communities against human land-use.

The results of the previous chapters raised the question, whether enrichment of oil palm plantations with other tree species can help to reverse the strong structuring effects of human land-use and partly recover the mycorrhizal community. To address this question, I analyzed the effect of tree species enrichment islands in an intensively managed oil palm plantation on the soil fungal community composition. Islands of native tree species (Parkia speciosa, Archidendron pauciflorum, Durio zibethinus, Peronema canescens, Shorea leprosula, Dyera polyphylla) were planted in an oil palm monoculture and further management was stopped within the islands to allow for natural undergrowth succession. After three years of enrichment cultivation, I tested the hypothesis that tree enrichment alters the taxonomic and functional soil fungal community composition in comparison with that in the soil of intensely managed oil palm plantations. However, no significant effects of tree species richness, or presence of individual tree species on the fungal community composition were found. A small proportion of community variation $(<10 \%)$ was explained by soil 
abiotic conditions $(\mathrm{N}, \mathrm{C} / \mathrm{N}$ and $\mathrm{P})$ and the majority of variation remained unexplained. These results suggest that abiotic filters as the result of intensively managed land-use constitute a legacy to fungal communities, overruling structuring effects of the vegetation on soil fungal communities within the first years after stopping management.

This thesis demonstrated a severe structuring impact of anthropogenic land-use on the fungal community structures. Soil abiotic properties were a main driver of fungal community composition in roots and soil. For the first time, changes in root chemical traits were linked to changes in the root and soil fungal communities. The results of this thesis underpin that the observed community shifts may result in loss of ecosystem services such as tree nutrient provision and tree health because of impaired AM root colonization. Links between shifts in the fungal community and plant root vitality suggest negative plant soil feedbacks driven by fungal community shifts. Strong bottom-up regulatory effects by root chemical traits especially on the root associated fungal community was demonstrated. However, no structuring effects of three years of plant succession on soil fungal communities in a biodiversity enriched oil palm plantations was found. Time series are required to investigate long term structuring effects of plant top-down regulation of soil fungal communities and the spatial scale at which root traits can affect local soil fungal communities. In summary, this thesis provides valuable new insights in the fungal community assembly processes under human land-use and highlights important areas of future research. 


\section{General Introduction}

\subsection{Land conversion of tropical rainforests in South East Asia}

Tropical evergreen rain forests are the naturally occurring vegetation in regions near the equator with monthly mean temperatures from 24 to $30^{\circ} \mathrm{C}$, high annual precipitation (2000-4000 mm) and very short or absent dry periods (Whitmore, 1998). Large regions of tropical rain forest are located in the Amazon Basin of South America, the Congo Basin of Central Africa and the Indo-Malayan Archipelago (Olson et al., 2001). Together they make up less than five percent of the earth surface, however, harbor nearly two thirds of the world's flora and fauna diversity with a large proportion endemic species (Bierregaard, Lovejoy, Kapos, Santos, \& Hutchings, 1992; DeFries, Hansen, Newton, \& Hansen, 2005; DeFries et al., 2005; Kier et al., 2009). Tropical forest growth makes up roughly $33 \%$ of the world's terrestrial net primary productivity (Field, Behrenfeld, Randerson, \& Falkowski, 1998). Thereby, tropical forests significantly contribute to the world's carbon balance and thus, are critical for the mitigation of global climate change (Baccini et al., 2012; Bebber \& Butt, 2017; Bonan, 2008; Mitchard, 2018). Further, the forest's evapotranspiration can account for up to $50 \%$ of the regional rainfall and even actively initiate cloud and wind formation (Wright et al., 2017). Because of their enormous biodiversity, high species endemism, and significant contribution to the climate, tropical rain forests are of highest nature conservation interest (Brooks et al., 2006; Brooks et al., 2002; Freudenberger et al., 2013). Myers et al. (2000) located 9 of the 25 outstanding biodiversity hotspots - ecosystems with the worldwide highest proportion of endemic plant and vertebrate species, highest species to area ratios and large proportions of habitat loss - in tropical forest ecosystems. Human land-use caused these unique and valuable forests to rapidly disappear in the past decades (Achard et al., 2002; Gibbs et al., 2010; Laurance, 1999) and due to the world's population growth and increasing demand for resources, deforestation rates are likely to continue (Barlow et al., 2018; Taubert et al., 2018; Vieilledent, Grinand, \& Vaudry, 2013). This deforestation led to mass species extinctions (Alroy, 2017; Barlow et al., 2018; Haddad et al., 2015; Whitmore, 1998), can be linked to severe droughts and wildfires (Cochrane, 2003; Zhang et al., 2007), and contributes approximately 10 $\%$ of the man-made climate gas emissions (Achard et al., 2014; Baccini et al., 2012; Csillik, Kumar, Mascaro, O’Shea, \& Asner, 2019).

The rain forest of South East Asia makes up roughly 15\% of the world's tropical forests (Estoque et al., 2019; Stibig, Achard, Carboni, Raši, \& Miettinen, 2014) and includes four of the above noted biodiversity hotspots (Myers et al., 2000). In the past decade these South East Asian forests experienced the highest deforestation rates, habitat loss, and decline of biodiversity among all 
tropical rain forest ecosystems (Miettinen, Shi, \& Liew, 2011; Sodhi, Koh, Brook, \& Ng, 2004; Stibig et al., 2014). In particular, Indonesia experienced unprecedented deforestation until today (Estoque et al., 2019; Margono, Potapov, Turubanova, Stolle, \& Hansen, 2014). Intensive logging of Indonesia's forests started in the mid $20^{\text {th }}$ century and was usually followed by conversion into profitable permanent monoculture plantations such as rubber (Hevea brasiliensis) and oil palm (Elaeis guineensis) (Drescher et al., 2016; Koh, 2007; Tsujino, Yumoto, Kitamura, Djamaluddin, \& Darnaedi, 2016). Rubber is native to Brazil and was introduced to Indonesia around 1910. The product - natural rubber - is harvested from the tree latex, dried and further refined into its elastic form. The material found application in wide range of products, particularly in the production of car tires (Priyadarshan, 2017). Synthetitical alternatives were developed during rubber shortages in World War II, but most rubber based products still contain $50-100 \%$ natural rubber today (Priyadarshan, 2017). In Indonesia, rubber trees were initially planted within natural tree vegetation ("jungle rubber"), comprising low-input agroforestry systems (Figure 1.1.1 B). Soon after however, these cultivation forms were largely replaced by more productive and less labor intensive rubber monocultures (Priyadarshan, 2017, Figure 1.1.1 C). Today Indonesia is the second biggest rubber exporter in the world according to data from the Observatory of Economic Complexity (OEC: https://oec.world/en/profile/hs92/4001/, April 2020; Simones \& Hidalgo, 2011).

The oil palm (Elaeis guineensis), native to West Africa, is the main species grown for the commercial production of palm oil (Corley \& Tinker, 2015). The oil content of the fruit's fleshy mesocarp and hardened endocarp is exceptionally high (approximately $85 \%$ and $50 \%$ of dry mass, respectively) compared to other oil producing crops (Corley \& Tinker, 2015; Dussert et al., 2013). While oil from the mesocarp is mainly used in the food industry, the palm kernel oil finds applications in the technical industry, cosmetics, and soap (Corley \& Tinker, 2015). With an average of 3 (and potentially more than 8) tons of fruits per hectar and year, oil palm is the most efficient crop in terms of oil productivity per land area and year compared to other crops such as soy, oil seed rape or sunflower (Euler, Krishna, Schwarze, Siregar, \& Qaim, 2017; Woittiez, van Wijk, Slingerland, van Noordwijk, \& Giller, 2017). Oil palms were first introduced to Indonesia as early as 1848 and first cultivation efforts were made around 1910. However, with interruptions during World War II, South East Asia's oil palm industry only grew slowly until the early 80 's when it experienced a massive boom particularly in Malaysia and Indonesia (Corley \& Tinker, 2015). In the beginning of the new millennia oil palm cultivation was one of the world's most rapidly expanding agricultural industries (Carrasco, Larrosa, Milner-Gulland, \& Edwards, 2014; Koh, 2007). Currently, Indonesia is the biggest exporter of palm oil, satisfying 55\% of the worldwide demand (OEC: https://oec.world/en/profile/hs92/1511/, April 2020, Simones \& Hidalgo, 2011). Due to the high economic yields in relation to labor input, a significant proportion of Indonesia's arable land was converted to oil palm plantations and has lead to 
economical upraise of many smallholder farmers (Euler et al., 2017; Euler, Schwarze, Siregar, \& Qaim, 2016; Kubitza, Krishna, Alamsyah, \& Qaim, 2018). At the same time, the increasing demand on oil led to ongoing conversion of pristine forest into plantations. In fact, palm oil cultivation was one of the main drivers of deforestation during the past two decades (Stibig et al., 2014; Vijay, Pimm, Jenkins, \& Smith, 2016). As a consequence vast areas of Indonesia's landscape are now dominated by intensively managed oil palm monocultures (Figure 1.1.1 D). The clash of environmental destruction on the one hand and high yield efficiency, strong demand and economic benefits on the other hand, urgently require scientifically advised strategies to guide a sustainable, ecosystem-friendly palm oil industry with minimized economic losses. For example, plant diversity enriched agroforestry systems could help to mediate the negative ecological effects of oil palm cultivation on the ecosystem (Zemp, Ehbrecht, et al., 2019; Zemp, Gérard, et al., 2019). The project for Ecological and Socioeconomic Functions of Tropical Lowland Rainforest Transformation Systems (EFForTS) is a German-Indoneasian research project with the goal to identify major ecological as well as social and economic consequences of palm oil cultivation (https://www.uni-goettingen.de/en/310995.html, April 2020). The project includes over 160 researchers from a wide range of disciplines including ecology, agriculture, forestry, economics, human geography and cultural anthropology. Research plots covering natural rainforest sites as well as common land-use systems (jungle - rubber, rubber and oil palm monocultures) were established in 2012 in central Sumatra (Figure 1.1.2). Further, empirical field studies are complemented by a large scale field experiment, to test the effect of tree diversity enrichment in oil palm plantations on stand structural complexity, multitrophic diversity and ecosystem functions (Figure 1.1.2). The study presented here was carried out within the broader framework of the EFForTS project. I specifically investigated diversity and composition of fungal communities in soil and associated with roots in land-transformation systems and in the tree species enrichment experiment. 

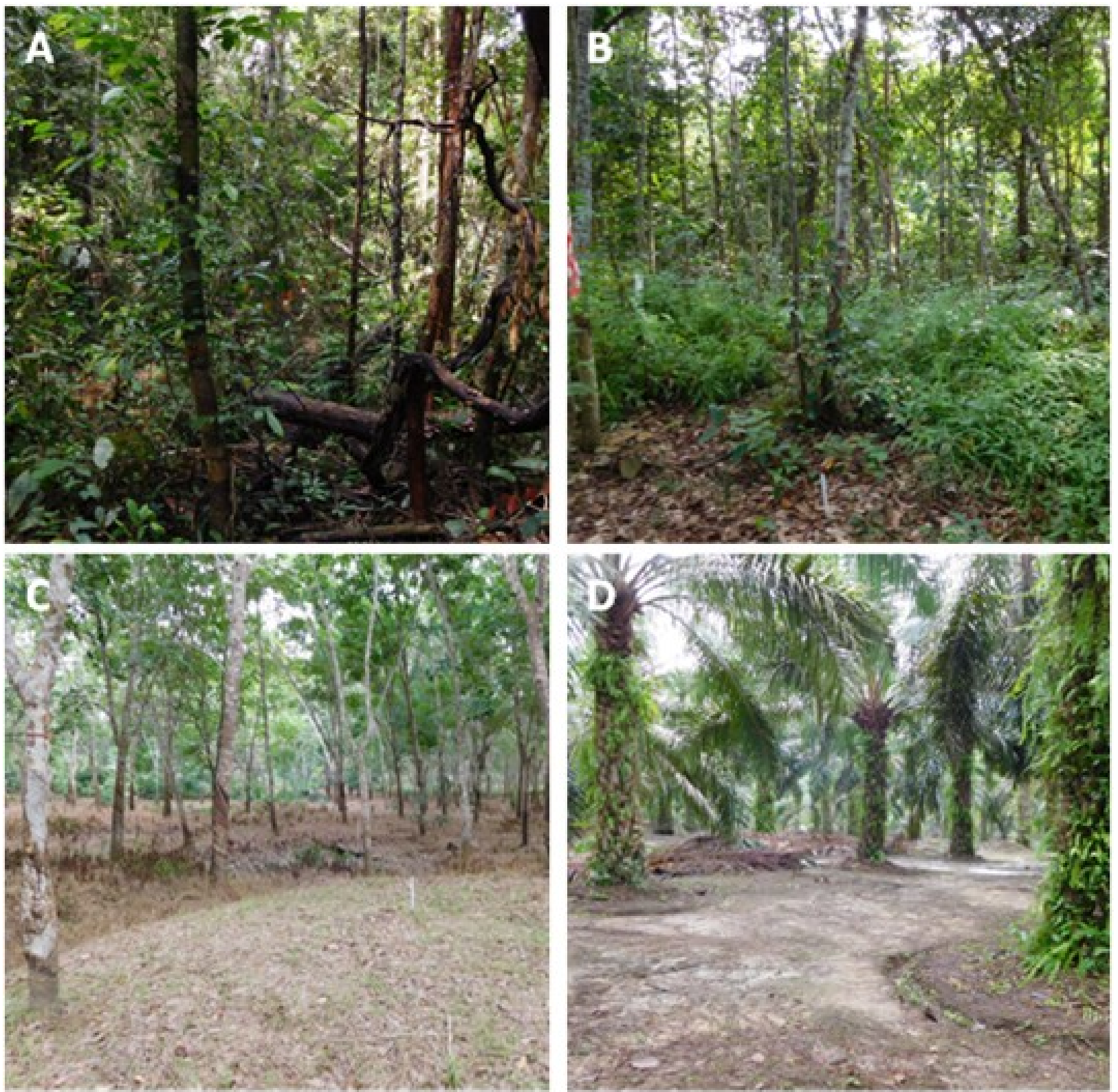

Figure 1.1.1 Impressions from the research sites in October 2016 representing important land-use systems on Sumatra (Indonesia): Diverse and structurally rich tropical rain forest (A), extensively managed jungle rubber (B), monoculture rubber plantation (C) and monoculture oil palm plantation (D). 


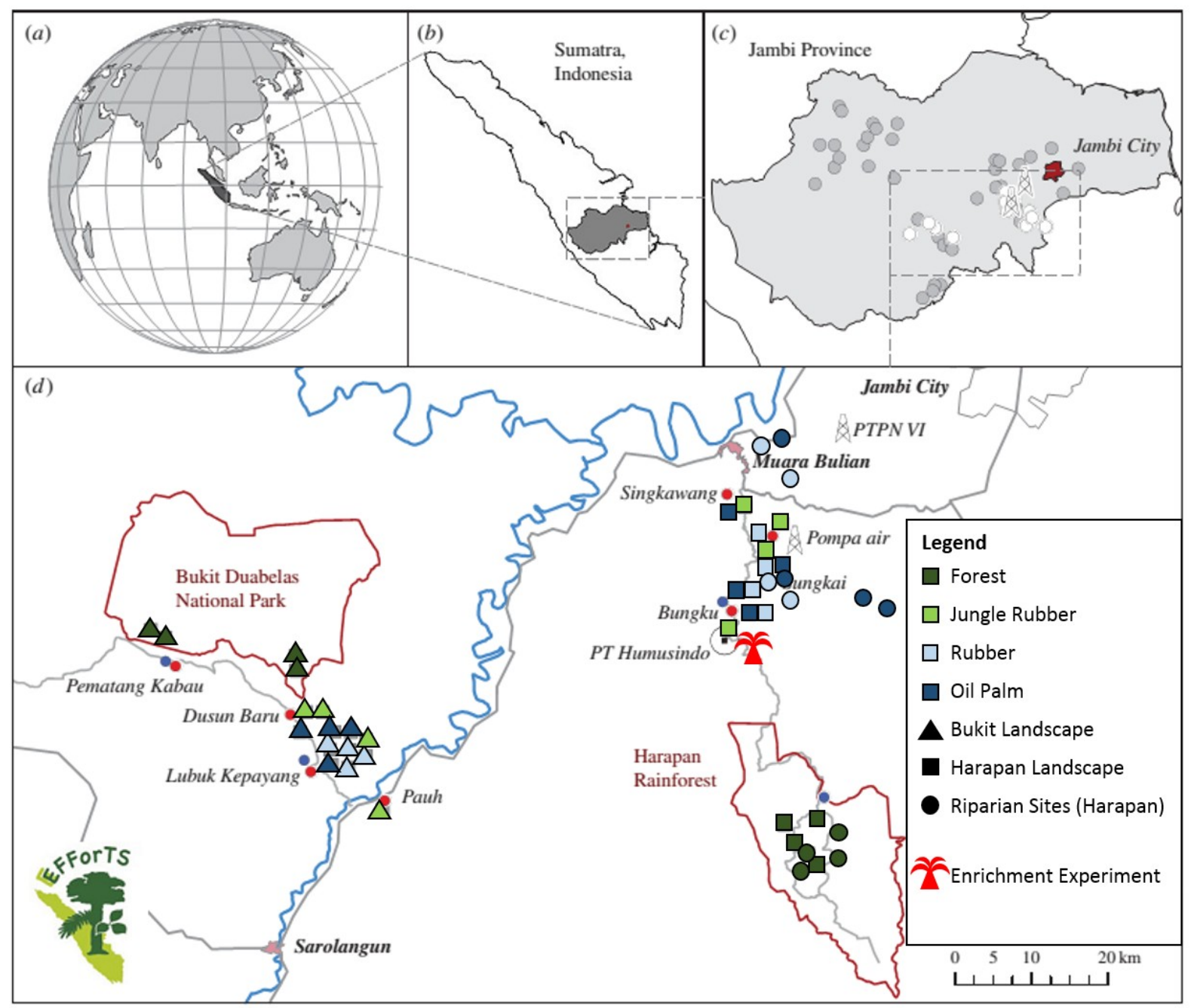

Figure 1.1.2 Location of the research plots of the EFForTS project in Sumatra $(a, b)$, Jambi province (c, d) - adapted from Drescher et al. (2016).

\subsection{The root-fungal continuum}

Fungi are heterotrophic, eukaryotic microorganisms. They are present in all soils and play a key role in nutrient and carbon flow of terrestrial ecosystems (Frąc, Hannula, Bełka, \& Jędryczka, 2018; Johnson, Angelard, Sanders, \& Kiers, 2013; Rillig, 2004; Tedersoo, Bahram, \& Dickie, 2014; van der Heijden, Bardgett, \& van Straalen, 2008). They exist either as unicellular organisms (yeasts) or as microscopic cell filaments (hyphae), which in some species form complex macroscopic structures such as fruiting bodies (sporocarp) or large sclerotia (Webster \& Weber, 2007). Many species can also switch between growth forms and are capable of asexual (anamorph) as well as sexual (teleomorph) reproduction (Webster \& Weber, 2007). The global fungal species richness remains under debate but estimates range from 1.5 to as high as 10 million species (Blackwell, 2011; Hawksworth, 1991; Hawksworth \& Lücking, 2017; O’Brien, Parrent, Jackson, Moncalvo, \& Vilgalys, 2005). The biology and life style of many species, especially from tropical regions, remains unknown 
(Fierer, 2017; Nguyen et al., 2016). However, a large proportion of fungal species is interacting with plants (Philippot, Raaijmakers, Lemanceau, \& van der Putten, 2013; van der Heijden, Dombrowski, \& Schlaeppi, 2017). Vegetation and fungal communities, including those associated with plant roots are often tightly linked (Peay, Baraloto, \& Fine, 2013; Rodríguez-Echeverría et al., 2017; Šmilauer, Košnar, Kotilínek, \& Šmilauerová, 2020; Yang et al., 2019; Yang, Dou, Huang, \& An, 2017). Interactions between plants and fungi can be classified into broad functional groups (symbiotroph, saprothroph, pathotroph) according to their feeding strategy (Nguyen et al., 2016). A majority of soil fungi has a saprotrophic live style and can efficiently degrade a vast range of substrates including complex organic macromolecules such as lignin or cellulose (Webster \& Weber, 2007). Thus, they are a key component in degradation of litter and plant roots, regulating carbon flow between atmosphere and biosphere and distribute nutrients across the soil biome (Prescott \& Grayston, 2013; Six, Frey, Thiet, \& Batten, 2006; Treseder \& Lennon, 2015). Many other fungi are plant pathogens that can cause severe diseases and pests. Fungal plant pathogens occur in a multitude of taxonomic clades. They range from obligate biotroph to nectrotroph and can be highly host specific or opportunistically colonize a wide range of plant species (Fisher et al., 2012; James et al., 2006; Lo Presti et al., 2015; Möller \& Stukenbrock, 2017). Plant pathogenic fungi can strongly alter the plant community and in agricultural systems, including oil palm plantations, they cause severe economic losses (Hushiarian, Yusof, \& Dutse, 2013; Paterson, 2019; Pilotti, 2005). A third group of important fungi are mycorrhiza. Approximately $80-90 \%$ of all plant species form a mutualistic symbiosis with mycorrhizal fungi (Smith \& Read, 2008). These fungi colonize the plant roots and provide their host with mineral nutrients, mainly nitrogen and phosphorous, in exchange for carbon. Further they can mitigate drought stress and protect the plant roots from pathogens (Egerton-Warburton, Querejeta, \& Allen, 2007; Jung, Martinez-Medina, Lopez-Raez, \& Pozo, 2012; Peña, Echeverría, Putten, Freitas, \& Moens, 2006; Smith \& Read, 2008). Mycorrhiza can be divided into several groups according to their ecology, taxonomy and plant hosts but the two most common ones are ectomycorrhiza and arbuscular mycorrhiza (Smith \& Read, 2008). While these groups have functional similarities they widely differ in their evolutionary origin as well as interaction strategies and morphology (Smith \& Read, 2008). Ectomycorrhizal fungi (EM) are dominant in boreal and temperate forests commonly associated with Fagaceae, Pinaceae and Salicaceae. However, they also occur in tropical forests of South East Asia mainly associated with trees specie from Fabaceae and Dipterocarpaceae (Soudzilovskaia et al., 2019; Steidinger et al., 2019). They grow dense hyphal structures around the roots of their plant hosts (mantle) and surround the root cortex cells with an extracellular hyphal network (Hartig net), where resource exchange takes place (Smith \& Read, 2008). Typically, EM form big mycelial networks (extraradical mycelia) in the surrounding soil and litter layer (Agerer, 2001; Smith \& Read, 2008). Some EM species are host specific while EM plants typically interact with multiple EM fungal species. 
The interaction most likely evolved multiple times in various saprotrophic clades of Asco- and Basidiomycota (Hibbett, Gilbert, \& Donoghue, 2000; Tedersoo, May, \& Smith, 2010) and a large number of EM species exists, compared to the relatively small number of EM forming plant hosts (van der Heijden, Martin, Selosse, \& Sanders, 2015; Werner \& Kiers, 2015). In contrast, arbuscular mycorrhizal fungi (AM) are a monophyletic group in the clade of Glomeromycota (Smith \& Read, 2008). All species within this basal group of fungi form an obligate symbiosis with plants. They most likely evolved together with the first land plants and a majority of plant species today still form AM (Bonfante \& Genre, 2008; Selosse, Strullu-Derrien, Martin, Kamoun, \& Kenrick, 2015; Strullu-Derrien et al., 2014). Thus, AM fungi are dominant in all grassland ecosystems, many tropical forests as well as in agricultural crop plantations (Smith \& Read, 2008; Steidinger et al., 2019). Typically, AM grow as extracellular hyphae between the plants cortex cells. At location of interaction they benetrate the cortex cell walls and cause invagination of the plasma membrane, forming prominent, multiple branched interaction structures (arbuscle) (Smith \& Read, 2008). The extraradical mycelia are typically restricted to short, single hyphal filament. Many AM species form prominent, thick walled, multinucleate spores in the soil (Smith \& Read, 2008). Those are frequently used to estimate abundance and morphological diversity of AM in soil (Guadarrama \& Álvarez-Sánchez, 1999; Johnson et al., 2013; Oehl et al., 2010, 2003). Global AM species richness is small compared to the number of host plant species and AM show little host specificity as well as low global endemism (Davison, Öpik, Daniell, Moora, \& Zobel, 2011; Engelmoer \& Kiers, 2015).

The fungal community strongly contributes to plant health and drives plant soil feedbacks (Clemmensen et al., 2013; Frąc et al., 2018; García-Guzmán \& Heil, 2014; Lance, Carrino-Kyker, Burke, \& Burns, 2020; Martin, Selosse, \& Sanders, 2015; van der Heijden et al., 2017). Therefore, it is important to understand the structuring effects that influence the fungal community assembly. Anthropogenic land-use, especially deforestation and conversion to plantations, represents one of the strongest ecological gradients worldwide (Newbold et al., 2015) and strongly affects soil microbial community composition and functionality (Bachelot et al., 2016; Lauber, Strickland, Bradford, \& Fierer, 2008; Sepp, Jairus, Vasar, Zobel, \& Öpik, 2018; Tian et al., 2017; Vályi, Rillig, \& Hempel, 2015). In oil palm plantations those changes were associated with reduced AM abundance and impaired chemical root traits (Brinkmann et al., 2019, cf. Appendix 1; Sahner et al., 2015). Changes in the plant community, increased land-use intensity, and edaphic conditions likely govern the shifts of fungal communities between tropical land-use systems; however their relative importance in structuring fungal community composition and functionality in tropical land-use systems is poorly understood. Furthermore, root associated and soil fungal communities have not been studied independently in those systems. 


\subsection{Goals of this thesis}

The present study aims to advance our understanding how tropical land transformation and land-use intensity affect the fungal diversity, community composition, and functionality and which environmental drivers facilitate these processes. Thereby, this research can help to develop sustainable management strategies to boost plant beneficial functions of the soil fungal community. This study is divided into three research chapters.

In the first chapter, the effects of land-use intensity across important land-use systems (rainforest, jungle rubber, rubber plantations and oil palm plantations) on the root-associated AM community were analyzed. A land-use intensity index (LUI) was calculated for all studied plots and used to test the following hypotheses:

- LUI negatively affects AM diversity and abundance across different land-use systems

- AM community shifts are driven by LUI and intensive land-use favors generalist AM fungi

The second chapter compares the relative importance of biotic plant-related and abiotic soil-related filters on the assembly of fungal communities in soil and associated with plant roots. Changes of soil chemical properties and chemical plant root traits across different land use systems were studied and their effects on changes in the soil- and root-associated fungal saprotrophic, pathotrophic and mycorrhizal communities were analyzed. The following hypotheses were tested:

- The root fungal community (RFC) is depending on plant root traits and, therefore, the turnover of RFC responds to changes in root properties more strongly than to changes to soil properties

- The soil fungal community (SFC) provides the pool from which the root fungi are recruited; the turnover of the SFC is mainly determined by changes in soil properties and stochastic fluctuations

- Assembly processes of all fungal groups are driven by soil chemistry but the community structure of saprotrophs, pathogens and mycorrhizal fungi on roots underlie additional, divergent controls by root traits.

Finally, the third chapter addresses the effect of enrichment of an oil palm monoculture with indigenous tree species as a management strategy to counteract changes in the soil fungal community composition.

- Tree diversity enrichment and natural plant succession alter soil fungal communities and promote the abundance of mycorrhizal fungi in soil 
- Individual tree host species contribute differently to the taxonomic and functional composition of the soil fungal community

\section{Literature}

Achard, F., Beuchle, R., Mayaux, P., Stibig, H.-J., Bodart, C., Brink, A., Carboni, S., Desclée, B., Donnay, F., Eva, H. D., Lupi, A., Raši, R., Seliger, R., \& Simonetti, D. (2014). Determination of tropical deforestation rates and related carbon losses from 1990 to 2010. Global Change Biology, 20(8), 2540-2554. doi: 10.1111/gcb.12605

Achard, F., Eva, H. D., Stibig, H.-J., Mayaux, P., Gallego, J., Richards, T., \& Malingreau, J.-P. (2002). Determination of deforestation rates of the world's humid tropical forests. Science, 297(5583), 9991002. doi: $10.1126 /$ science. 1070656

Agerer, R. (2001). Exploration types of ectomycorrhizae. Mycorrhiza, 11(2), 107-114. doi: $10.1007 / \mathrm{s} 005720100108$

Alroy, J. (2017). Effects of habitat disturbance on tropical forest biodiversity. Proceedings of the National Academy of Sciences, 114(23), 6056-6061. doi: 10.1073/pnas.1611855114

Baccini, A., Goetz, S. J., Walker, W. S., Laporte, N. T., Sun, M., Sulla-Menashe, D., Hackler, J., Beck, P. S. A., Dubayah, R., Friedl, M. A., Samanta, S., \& Houghton, R. A. (2012). Estimated carbon dioxide emissions from tropical deforestation improved by carbon-density maps. Nature Climate Change, 2(3), 182-185. doi: $10.1038 /$ nclimate1354

Bachelot, B., Uriarte, M., Zimmerman, J. K., Thompson, J., Leff, J. W., Asiaii, A., Koshner, J., \& McGuire, K. (2016). Long-lasting effects of land use history on soil fungal communities in second-growth tropical rain forests. Ecological Applications, 26(6), 1881-1895. doi: 10.1890/15-1397.1

Barlow, J., França, F., Gardner, T. A., Hicks, C. C., Lennox, G. D., Berenguer, E., Castello, L., Economo, E. P., Ferreira, J., Guénard, B., Gontijo Leal, C., Isaac, V., Lees, A. L., Wilson, S. K., Young, P. J., \& Graham, N. A. J. (2018). The future of hyperdiverse tropical ecosystems. Nature, 559(7715), 517-526. doi: 10.1038/s41586-018-0301-1

Bebber, D. P., \& Butt, N. (2017). Tropical protected areas reduced deforestation carbon emissions by one third from 2000-2012. Scientific Reports, 7(1), 1-7. doi: 10.1038/s41598-017-14467-w

Bierregaard, R. O., Lovejoy, T. E., Kapos, V., Santos, A. A. dos, \& Hutchings, R. W. (1992). The biological dynamics of tropical rainforest fragments. BioScience, 42(11), 859-866. doi: 10.2307/1312085

Blackwell, M. (2011). The Fungi: 1, 2, 3 ... 5.1 million species? American Journal of Botany, 98(3), 426-438. doi: 10.3732/ajb.1000298

Bonan, G. B. (2008). Forests and climate change: Forcings, feedbacks, and the climate benefits of forests. Science, 320(5882), 1444-1449. doi: 10.1126/science.1155121

Bonfante, P., \& Genre, A. (2008). Plants and arbuscular mycorrhizal fungi: An evolutionary-developmental perspective. Trends in Plant Science, 13(9), 492-498. doi: 10.1016/j.tplants.2008.07.001

Brinkmann, N., Schneider, D., Sahner, J., Ballauff, J., Edy, N., Barus, H., Irawan, B., Budi, S. W., Qaim, M., Daniel, R., \& Polle, A. (2019). Intensive tropical land use massively shifts soil fungal communities. Scientific Reports, 9(1), 3403. doi: 10.1038/s41598-019-39829-4

Brooks, T. M., Mittermeier, R. A., da Fonseca, G. A. B., Gerlach, J., Hoffmann, M., Lamoreux, J. F., Mittermeier, C. G., Pilgrim, J. D., \& Rodrigues, A. S. L. (2006). Global biodiversity conservation priorities. Science, 313(5783), 58-61. doi: 10.1126/science.1127609

Brooks, Thomas M., Mittermeier, R. A., Mittermeier, C. G., da Fonseca, G. A., Anthony, R. B., Konstant, W. R., Flick, P., \& Hilton-Taylor, C. (2002). Habitat loss and extinction in the hotspots of biodiversity. Conservation Biology, 16(4), 909-923.

Carrasco, L. R., Larrosa, C., Milner-Gulland, E. J., \& Edwards, D. P. (2014). A double-edged sword for tropical forests. Science, 346(6205), 38-40. doi: 10.1126/science.1256685

Cochrane, M. A. (2003). Fire science for rainforests. Nature, 421(6926), 913-919. doi: 10.1038/nature01437

Corley, R. H. V., \& Tinker, P. B. H. (2015). The oil palm (5th Edition). Hoboken, USA: Wiley-Blackwell. 
Csillik, O., Kumar, P., Mascaro, J., O’Shea, T., \& Asner, G. P. (2019). Monitoring tropical forest carbon stocks and emissions using Planet satellite data. Scientific Reports, 9(1), 1-12. doi: 10.1038/s41598-019-54386-6

Davison, J., Öpik, M., Daniell, T. J., Moora, M., \& Zobel, M. (2011). Arbuscular mycorrhizal fungal communities in plant roots are not random assemblages. FEMS Microbiology Ecology, 78(1), 103-115. doi: 10.1111/j.1574-6941.2011.01103.x

Defries, R., Hansen, A., Newton, A. C., \& Hansen, M. C. (2005). Increasing isolation of protected areas in tropical forests over the past twenty years. Ecological Applications, 15(1), 19-26. doi: 10.1890/035258

Drescher, J., Rembold, K., Allen, K., Beckschäfer, P., Buchori, D., Clough, Y., Faust, H., Fauzi, A. M., Gunawan, D., \& Hertel, D. (2016). Ecological and socio-economic functions across tropical land use systems after rainforest conversion. Phil. Trans. R. Soc. B, 371(1694), 20150275.

Dussert, S., Guerin, C., Andersson, M., Joët, T., Tranbarger, T. J., Pizot, M., Sarah, G., Omore, A., DurandGasselin, T., \& Morcillo, F. (2013). Comparative transcriptome analysis of three oil palm fruit and seed tissues that differ in oil content and fatty acid composition ${ }^{1[\mathrm{C}][\mathrm{W}][\mathrm{OA}]}$. Plant Physiology, 162(3), 13371358. doi: 10.1104/pp.113.220525

Egerton-Warburton, L. M., Querejeta, J. I., \& Allen, M. F. (2007). Common mycorrhizal networks provide a potential pathway for the transfer of hydraulically lifted water between plants. Journal of Experimental Botany, 58(6), 1473-1483. doi: 10.1093/jxb/erm009

Engelmoer, D. J. P., \& Kiers, E. T. (2015). Host diversity affects the abundance of the extraradical arbuscular mycorrhizal network. New Phytologist, 205(4), 1485-1491. doi: 10.1111/nph.13086

Estoque, R. C., Ooba, M., Avitabile, V., Hijioka, Y., DasGupta, R., Togawa, T., \& Murayama, Y. (2019). The future of Southeast Asia's forests. Nature Communications, 10(1), 1-12. doi: 10.1038/s41467-019-09646-4

Euler, M., Krishna, V., Schwarze, S., Siregar, H., \& Qaim, M. (2017). Oil palm adoption, household welfare, and nutrition among smallholder farmers in Indonesia. World Development, 93, 219-235. doi: 10.1016/j.worlddev.2016.12.019

Euler, M., Schwarze, S., Siregar, H., \& Qaim, M. (2016). Oil palm expansion among smallholder farmers in Sumatra, Indonesia. Journal of Agricultural Economics, 67(3), 658-676. doi: 10.1111/1477-9552.12163

Field, C. B., Behrenfeld, M. J., Randerson, J. T., \& Falkowski, P. (1998). Primary production of the biosphere: Integrating terrestrial and oceanic components. Science, 281(5374), 237-240. doi: 10.1126/science.281.5374.237

Fierer, N. (2017). Embracing the unknown: Disentangling the complexities of the soil microbiome. Nature Reviews Microbiology, 15(10), 579-590. doi: 10.1038/nrmicro.2017.87

Fisher, M. C., Henk, Daniel. A., Briggs, C. J., Brownstein, J. S., Madoff, L. C., McCraw, S. L., \& Gurr, S. J. (2012). Emerging fungal threats to animal, plant and ecosystem health. Nature, 484(7393). doi: 10.1038 /nature10947

Frąc, M., Hannula, S. E., Bełka, M., \& Jędryczka, M. (2018). Fungal biodiversity and their role in soil health. Frontiers in Microbiology, 9. doi: 10.3389/fmicb.2018.00707

Freudenberger, L., Hobson, P., Schluck, M., Kreft, S., Vohland, K., Sommer, H., Reichle, S., Nowicki, C., Barthlott, W., \& Ibisch, P. L. (2013). Nature conservation: Priority-setting needs a global change. Biodiversity and Conservation, 22(5), 1255-1281. doi: 10.1007/s10531-012-0428-6

García-Guzmán, G., \& Heil, M. (2014). Life histories of hosts and pathogens predict patterns in tropical fungal plant diseases. New Phytologist, 201(4), 1106-1120. doi: 10.1111/nph.12562

Gibbs, H. K., Ruesch, A. S., Achard, F., Clayton, M. K., Holmgren, P., Ramankutty, N., \& Foley, J. A. (2010). Tropical forests were the primary sources of new agricultural land in the 1980s and 1990s. Proceedings of the National Academy of Sciences, 107(38), 16732-16737.

Guadarrama, P., \& Álvarez-Sánchez, F. J. (1999). Abundance of arbuscular mycorrhizal fungi spores in different environments in a tropical rain forest, Veracruz, Mexico. Mycorrhiza, 8(5), 267-270. doi: 10.1007/s005720050244

Haddad, N. M., Brudvig, L. A., Clobert, J., Davies, K. F., Gonzalez, A., Holt, R. D., Lovejoy, T. E., Sexton, J. O., Austin, M. P., Collins, C. D., Cook, W. M., Damschen, E. I., Ewers, R. M., Foster, B. L., Jenkins, C. N., King, A. J., Laurance, W. F., Levey, D. J., Margules, C. R., Melbourne, B. A., Nicholls, A. O., Orrock, J. L., Song, D.-X., \& Townshend, J. R. (2015). Habitat fragmentation and its lasting impact on Earth's ecosystems. Science Advances, 1(2), e1500052. doi: 10.1126/sciadv.1500052 
Hawksworth, D. L. (1991). The fungal dimension of biodiversity: Magnitude, significance, and conservation. Mycological Research, 95(6), 641-655.

Hawksworth, D. L., \& Lücking, R. (2017). Fungal diversity revisited: 2.2 to 3.8 million species. Microbiol Spectrum 5(4). doi: 10.0.4.104/microbiolspec.FUNK-0052-2016

Hibbett, D. S., Gilbert, L.-B., \& Donoghue, M. J. (2000). Evolutionary instability of ectomycorrhizal symbioses in basidiomycetes. Nature, 407(6803), 506-508. doi: 10.1038/35035065

Hushiarian, R., Yusof, N. A., \& Dutse, S. W. (2013). Detection and control of Ganoderma boninense: Strategies and perspectives. SpringerPlus, 2. doi: 10.1186/2193-1801-2-555

James, T. Y., Kauff, F., Schoch, C. L., Matheny, P. B., Hofstetter, V., Cox C. J., Celio, G., Gueidan, C., Fraker, E., Miadlikowska, J., Lumbsch H., T., Rauhut, A., Reeb, V., Arnold, A. E., Amtoft, A., Stajich, J. E., Hosaka, K., Sung, G.-H., Johnson, D., O’Rourke, B., Crockett, M., Binder, M., Curtis, J. M., Slot J. C., Wang, Z., Wilson A. W., Schüßler, A., Longcore J. E., O’Donnell, K., Mozley-Standridge, S., Porter, D., Letcher, P. M., Powell, M. J., Taylor J. W., White, M. M., Griffith, G. W., Davies, D. R., Humber, R. A., Morton, J. B., Sugiyama, J., Rossman, A. Y., Rogers, J. D, Pfister, D. H., Hewitt, D., Hansen, K., Hambleton, S., Shoemaker, R. A., Kohlmeyer, J., Volkmann-Kohlmeyer, B., Spotts, R. A., Serdani, M., Crous, P. W., Hughes, K. W., Matsuura, K., Langer, E., Langer, G., Untereiner, W. A., Lücking, R., Büdel, B., Geiser, D. M., Aptroot, A., Diederich, P., Schmitt, I., Schultz, M., Yahr, R., Hibbett, D. S., Lutzoni, F., McLaughlin, D. J., Spatafora, J. W., \& Vilgalys, R. (2006). Reconstructing the early evolution of Fungi using a six-gene phylogeny. Nature, 443(7113), 818-822. doi: 10.1038/nature05110

Johnson, N. C., Angelard, C., Sanders, I. R., \& Kiers, E. T. (2013). Predicting community and ecosystem outcomes of mycorrhizal responses to global change. Ecology Letters, 16(s1), 140-153. doi: 10.1111/ele.12085

Jung, S. C., Martinez-Medina, A., Lopez-Raez, J. A., \& Pozo, M. J. (2012). Mycorrhiza-induced resistance and priming of plant defenses. Journal of Chemical Ecology, 38(6), 651-664. doi: 10.1007/s10886-0120134-6

Kier, G., Kreft, H., Lee, T. M., Jetz, W., Ibisch, P. L., Nowicki, C., Mutke J., \& Barthlott, W. (2009). A global assessment of endemism and species richness across island and mainland regions. Proceedings of the National Academy of Sciences, 106(23), 9322-9327. doi: 10.1073/pnas.0810306106

Koh, L. P. (2007). Impending disaster or sliver of hope for Southeast Asian forests? The devil may lie in the details. Biodiversity and Conservation, 16(13), 3935-3938. doi: 10.1007/s10531-007-9177-3

Kubitza, C., Krishna, V. V., Alamsyah, Z., \& Qaim, M. (2018). The economics behind an ecological crisis: Livelihood effects of oil palm expansion in Sumatra, Indonesia. Human Ecology, 46(1), 107-116. doi: 10.1007/s10745-017-9965-7

Lance, A. C., Carrino-Kyker, S. R., Burke, D. J., \& Burns, J. H. (2020). Individual plant-soil feedback effects influence tree growth and rhizosphere fungal communities in a temperate forest restoration experiment. Frontiers in Ecology and Evolution, 7. doi: 10.3389/fevo.2019.00500

Lauber, C. L., Strickland, M. S., Bradford, M. A., \& Fierer, N. (2008). The influence of soil properties on the structure of bacterial and fungal communities across land-use types. Soil Biology and Biochemistry, 40(9), 2407-2415. doi: 10.1016/j.soilbio.2008.05.021

Laurance, W. F. (1999). Reflections on the tropical deforestation crisis. Biological Conservation, 91(2), $109-117$. doi: 10.1016/S0006-3207(99)00088-9

Lo Presti, L., Lanver, D., Schweizer, G., Tanaka, S., Liang, L., Tollot, M., Zuccaro, A., Reissmann, S., \& Kahmann, R. (2015). Fungal effectors and plant susceptibility. Annual Review of Plant Biology, 66(1), 513-545. doi: 10.1146/annurev-arplant-043014-114623

Margono, B. A., Potapov, P. V., Turubanova, S., Stolle, F., \& Hansen, M. C. (2014). Primary forest cover loss in Indonesia over 2000-2012. Nature Climate Change, 4(8), 730-735. doi: 10.1038/nclimate2277

Miettinen, J., Shi, C., \& Liew, S. C. (2011). Deforestation rates in insular Southeast Asia between 2000 and 2010. Global Change Biology, 17(7), 2261-2270. doi: 10.1111/j.1365-2486.2011.02398.x

Mitchard, E. T. A. (2018). The tropical forest carbon cycle and climate change. Nature, 559(7715), 527-534. doi: 10.1038/s41586-018-0300-2

Möller, M., \& Stukenbrock, E. H. (2017). Evolution and genome architecture in fungal plant pathogens. Nature Reviews Microbiology, 15(12), 756-771. doi: 10.1038/nrmicro.2017.76

Myers, N., Mittermeier, R. A., Mittermeier, C. G., Da Fonseca, G. A., \& Kent, J. (2000). Biodiversity hotspots for conservation priorities. Nature, 403(6772), 853-858. 
Newbold, T., Hudson, L. N., Hill, S. L. L., Contu, S., , Lysenko, I., Senior, R. A., Börger, L., Bennett, D. J., Choimes, A., Collen B., Day, J., de Palma, A., Díaz, S., Echeverria-Londoño, S., Edgar, M. J., Feldman, A., Garon, M., Harrison M. L. K., Alhusseini, T., Ingram, D. J., Itescu, Y., Kattge, J., Kemp, V., Kirkpatrick, L., Kleyer, M., Correia, D. L. P., Martin, C. D., Meiri, S., Novosolov, M., Pan, Y., Phillips, H. R. P., Purves, D. W., Robinson, A., Simpson, J., Tuck, S. L., Weiher, E., White, H. J., Ewers, R. M., Mace, G. M., Scharlemann, J. P. W., \& Purvis, A. (2015). Global effects of land use on local terrestrial biodiversity. Nature, 520(7545), 45-50. doi: 10.1038/nature14324

Nguyen, N. H., Song, Z., Bates, S. T., Branco, S., Tedersoo, L., Menke, J., Schilling, J. S., \& Kennedy, P. G. (2016). FUNGuild: An open annotation tool for parsing fungal community datasets by ecological guild. Fungal Ecology, 20, 241-248. doi: 10.1016/j.funeco.2015.06.006

O'Brien, H. E., Parrent, J. L., Jackson, J. A., Moncalvo, J.-M., \& Vilgalys, R. (2005). Fungal community analysis by large-scale sequencing of environmental samples. Applied and Environmental Microbiology, 71(9), 5544-5550. doi: 10.1128/AEM.71.9.5544-5550.2005

Oehl, F., Laczko, E., Bogenrieder, A., Stahr, K., Bösch, R., van der Heijden, M., \& Sieverding, E. (2010). Soil type and land use intensity determine the composition of arbuscular mycorrhizal fungal communities. Soil Biology and Biochemistry, 42(5), 724-738. doi: 10.1016/j.soilbio.2010.01.006

Oehl, F., Sieverding, E., Ineichen, K., Mäder, P., Boller, T., \& Wiemken, A. (2003). Impact of land use intensity on the species diversity of arbuscular mycorrhizal fungi in agroecosystems of central Europe. Applied and Environmental Microbiology, 69(5), 2816-2824. doi: 10.1128/AEM.69.5.2816-2824.2003

Olson, D. M., Dinerstein, E., Wikramanayake, E. D., Burgess, N. D., Powell, G. V. N., Underwood, E. C., D'amico, J. A., Itoup, I., Strand, H. E., Morrison, J. C., Loucks, C. J., Allnutt, T. F., Ricketts, T. H., Kura, Y., Lamoreux, J. F., Wettengel, W. W., Hedao, P., \& Kassem, K. R. (2001). Terrestrial ecoregions of the world: A new map of life on Earth. A new global map of terrestrial ecoregions provides an innovative tool for conserving biodiversity. BioScience, 51(11), 933-938.

Paterson, R. R. M. (2019). Ganoderma boninense disease of oil palm to significantly reduce production after 2050 in Sumatra if projected climate change occurs. Microorganisms, 7(1). doi: 10.3390/microorganisms7010024

Peay, K. G., Baraloto, C., \& Fine, P. V. (2013). Strong coupling of plant and fungal community structure across western Amazonian rainforests. The ISME Journal, 7(9), 1852-1861.

Peña, E. D. L., Echeverría, S. R., Putten, W. H. V. D., Freitas, H., \& Moens, M. (2006). Mechanism of control of root-feeding nematodes by mycorrhizal fungi in the dune grass Ammophila arenaria. New Phytologist, 169(4), 829-840. doi: 10.1111/j.1469-8137.2005.01602.x

Philippot, L., Raaijmakers, J. M., Lemanceau, P., \& van der Putten, W. H. (2013). Going back to the roots: The microbial ecology of the rhizosphere. Nature Reviews Microbiology, 11(11), 789-799. doi: 10.1038/nrmicro3109

Pilotti, C. A. (2005). Stem rots of oil palm caused by Ganoderma boninense: Pathogen biology and epidemiology. Mycopathologia, 159(1), 129-137. doi: 10.1007/s11046-004-4435-3

Prescott, C. E., \& Grayston, S. J. (2013). Tree species influence on microbial communities in litter and soil: Current knowledge and research needs. Forest Ecology and Management, 309, 19-27. doi: 10.1016/j.foreco.2013.02.034

Priyadarshan, P. M. (2017). Biology of Hevea rubber. Berlin, Germany: Springer

Rillig, M. C. (2004). Arbuscular mycorrhizae and terrestrial ecosystem processes. Ecology Letters, 7(8), 740-754. doi: 10.1111/j.1461-0248.2004.00620.x

Rodríguez-Echeverría, S., Teixeira, H., Correia, M., Timóteo, S., Heleno, R., Öpik, M., \& Moora, M. (2017). Arbuscular mycorrhizal fungi communities from tropical Africa reveal strong ecological structure. New Phytologist, 213(1), 380-390. doi: 10.1111/nph.14122

Sahner, J., Budi, S. W., Barus, H., Edy, N., Meyer, M., Corre, M. D., \& Polle, A. (2015). Degradation of root community traits as indicator for transformation of tropical lowland rain forests into oil palm and rubber plantations. PLOS ONE, 10(9), e0138077. doi: 10.1371/journal.pone.0138077

Selosse, M.-A., Strullu-Derrien, C., Martin, F. M., Kamoun, S., \& Kenrick, P. (2015). Plants, fungi and oomycetes: A 400-million year affair that shapes the biosphere. New Phytologist, 206(2), 501-506. doi: 10.1111/nph.13371 
Sepp, S.-K., Jairus, T., Vasar, M., Zobel, M., \& Öpik, M. (2018). Effects of land use on arbuscular mycorrhizal fungal communities in Estonia. Mycorrhiza, 28(3), 259-268. doi: 10.1007/s00572-018-0822-3

Simones, A. J. G., \& Hidalgo, C. A. (2011). The Economic Complexity Observatory: An Analytical Tool for Understanding the Dynamics of Economic Development. Workshops at the Twenty-Fifth AAAI Conference on Artificial Intelligence.

Six, J., Frey, S. D., Thiet, R. K., \& Batten, K. M. (2006). Bacterial and fungal contributions to carbon sequestration in agroecosystems. Soil Science Society of America Journal, 70(2), 555. doi: 10.2136/sssaj2004.0347

Šmilauer, P., Košnar, J., Kotilínek, M., \& Šmilauerová, M. (2020). Contrasting effects of host identity, plant community, and local species pool on the composition and colonization levels of arbuscular mycorrhizal fungal community in a temperate grassland. New Phytologist, 225(1), 461-473. doi: 10.1111/nph.16112

Smith, S. E., \& Read, D. (2008). Mycorrhizal symbiosis. doi: 10.1016/B978-0-12-370526-6.X5001-6

Sodhi, N. S., Koh, L. P., Brook, B. W., \& Ng, P. K. L. (2004). Southeast Asian biodiversity: An impending disaster. Trends in Ecology \& Evolution, 19(12), 654-660. doi: 10.1016/j.tree.2004.09.006

Soudzilovskaia, N. A., Bodegom, P. M. van, Terrer, C., Zelfde, M. van't, McCallum, I., McCormack, M. L., Fisher, J. B., Brundrett, M. C., de Sá, N. C., \& Tedersoo, L. (2019). Global mycorrhizal plant distribution linked to terrestrial carbon stocks. Nature Communications, 10(1), 1-10. doi: 10.1038/s41467-019-13019-2

Steidinger, B. S., Crowther, T. W., Liang, J., Nuland, M. E. V., Werner, G. D. A., Reich, P. B., Nabuurs, G. J., de Miguel, S., Zhou, M., Picard, N., Herault, B., Zhao, X., Zhang, C., Routh, D., \& Peay, K. G. (2019). Climatic controls of decomposition drive the global biogeography of forest-tree symbioses. Nature, 569(7756), 404-408. doi: 10.1038/s41586-019-1128-0

Stibig, H.-J., Achard, F., Carboni, S., Raši, R., \& Miettinen, J. (2014). Change in tropical forest cover of Southeast Asia from 1990 to 2010. Biogeosciences, 11(2), 247-258. doi: 10.5194/bg-11-247-2014

Strullu-Derrien, C., Kenrick, P., Pressel, S., Duckett, J. G., Rioult, J.-P., \& Strullu, D.-G. (2014). Fungal associations in Horneophyton ligneri from the Rhynie Chert (c. 407 million year old) closely resemble those in extant lower land plants: Novel insights into ancestral plant-fungus symbioses. New Phytologist, 203(3), 964-979. doi: 10.1111/nph.12805

Taubert, F., Fischer, R., Groeneveld, J., Lehmann, S., Müller, M. S., Rödig, E., Wiegand, T., Huth, A. (2018). Global patterns of tropical forest fragmentation. Nature, 554(7693), 519-522. doi: 10.1038/nature25508

Tedersoo, L., Bahram, M., \& Dickie, I. A. (2014). Does host plant richness explain diversity of ectomycorrhizal fungi? Re-evaluation of Gao et al. (2013) data sets reveals sampling effects. Molecular Ecology, 23(5), 992-995.

Tedersoo, L., May, T. W., \& Smith, M. E. (2010). Ectomycorrhizal lifestyle in fungi: Global diversity, distribution, and evolution of phylogenetic lineages. Mycorrhiza, 20(4), 217-263. doi: 10.1007/s00572-009-0274-x

Tian, Q., Taniguchi, T., Shi, W.-Y., Li, G., Yamanaka, N., \& Du, S. (2017). Land-use types and soil chemical properties influence soil microbial communities in the semiarid Loess Plateau region in China. Scientific Reports, 7, 45289. doi: 10.1038/srep45289

Treseder, K. K., \& Lennon, J. T. (2015). Fungal traits that drive ecosystem dynamics on land. Microbiology and Molecular Biology Reviews, 79(2), 243-262. doi: 10.1128/MMBR.00001-15

Tsujino, R., Yumoto, T., Kitamura, S., Djamaluddin, I., \& Darnaedi, D. (2016). History of forest loss and degradation in Indonesia. Land Use Policy, 57, 335-347. doi: 10.1016/j.landusepol.2016.05.034

Vályi, K., Rillig, M. C., \& Hempel, S. (2015). Land-use intensity and host plant identity interactively shape communities of arbuscular mycorrhizal fungi in roots of grassland plants. New Phytologist, 205(4), 1577-1586. doi: 10.1111/nph.13236

van der Heijden, M. G. A., Bardgett, R. D., \& van Straalen, N. M. (2008). The unseen majority: Soil microbes as drivers of plant diversity and productivity in terrestrial ecosystems. Ecology Letters, 11(3), 296-310. doi: 10.1111/j.1461-0248.2007.01139.x

van der Heijden, M. G. A., Dombrowski, N., \& Schlaeppi, K. (2017). Continuum of root-fungal symbioses for plant nutrition. Proceedings of the National Academy of Sciences, 114(44), 11574-11576. doi: 10.1073/pnas.1716329114 
van der Heijden, M. G. A. van der, Martin, F. M., Selosse, M.-A., \& Sanders, I. R. (2015). Mycorrhizal ecology and evolution: The past, the present, and the future. New Phytologist, 205(4), 1406-1423. doi: 10.1111/nph.13288

Vieilledent, G., Grinand, C., \& Vaudry, R. (2013). Forecasting deforestation and carbon emissions in tropical developing countries facing demographic expansion: A case study in Madagascar. Ecology and Evolution, 3(6), 1702-1716. doi: 10.1002/ece3.550

Vijay, V., Pimm, S. L., Jenkins, C. N., \& Smith, S. J. (2016). The impacts of oil palm on recent deforestation and biodiversity loss. PLOS ONE, 11(7). doi: 10.1371/journal.pone.0159668

Webster, J., \& Weber, R. (2007). Introduction to fungi. Cambridge University Press.

Werner, G. D. A., \& Kiers, E. T. (2015). Partner selection in the mycorrhizal mutualism. New Phytologist, 205(4), 1437-1442. doi: 10.1111/nph.13113

Whitmore, T. C. (1998). An introduction to tropical rain forests (Second Edition). Oxford, New York: Oxford University Press.

Woittiez, L. S., van Wijk, M. T., Slingerland, M., van Noordwijk, M., \& Giller, K. E. (2017). Yield gaps in oil palm: A quantitative review of contributing factors. European Journal of Agronomy, 83, 57-77. doi: 10.1016/j.eja.2016.11.002

Wright, J. S., Fu, R., Worden, J. R., Chakraborty, S., Clinton, N. E., Risi, C., Sun, Y., \& Yin, L. (2017). Rainforestinitiated wet season onset over the southern Amazon. Proceedings of the National Academy of Sciences, 114(32), 8481-8486. doi: 10.1073/pnas.1621516114

Yang, T., Tedersoo, L., Soltis, P. S., Soltis, D. E., Gilbert, J. A., Sun, M., Shi, Y., Wang, H., Li, Y., Zhang, J., Chen, Z., Lin, H., Zhao, Y., Fu, C., \& Chu, H. (2019). Phylogenetic imprint of woody plants on the soil mycobiome in natural mountain forests of eastern China. The ISME Journal, 13(3), 686-697. doi: 10.1038/s41396018-0303-x

Yang, Y., Dou, Y., Huang, Y., \& An, S. (2017). Links between soil fungal diversity and plant and soil properties on the loess plateau. Frontiers in Microbiology, 8. doi: 10.3389/fmicb.2017.02198

Zemp, D. C., Ehbrecht, M., Seidel, D., Ammer, C., Craven, D., Erkelenz, J., Irawan , B., Sundawati, L., Hölscher, D., \& Kreft, H. (2019). Mixed-species tree plantings enhance structural complexity in oil palm plantations. Agriculture, Ecosystems \& Environment, 283, 106564. doi: 10.1016/j.agee.2019.06.003

Zemp, D. C., Gérard, A., Hölscher, D., Ammer, C., Irawan, B., Sundawati, L., Teuscher, M., \& Kreft, H. (2019). Tree performance in a biodiversity enrichment experiment in an oil palm landscape. Journal of Applied Ecology, 56(10), 2340-2352. doi: 10.1111/1365-2664.13460

Zhang, X., Zwiers, F. W., Hegerl, G. C., Lambert, F. H., Gillett, N. P., Solomon, S., Stott, P. A., \& Nozawa, T. (2007). Detection of human influence on twentieth-century precipitation trends. Nature, 448(7152), 461-465. doi: 10.1038/nature06025 


\section{Research Chapters}

\subsection{Land-use intensity drives diversity, abundance and community composition of arbuscular mycorrhizal fungi across tropical land-use systems}

\section{Introduction}

Arbuscular mycorrhizal fungi (Glomeromycota, AM) are the most common mutualistic plant symbionts in a majority of terrestrial ecosystems (Smith \& Read, 2008). They significantly improve plant access to soil nutrients in exchange for carbon and can further elevate plant drought and pathogen resistance (Egerton-Warburton, Querejeta, \& Allen, 2007; Jung, Martinez-Medina, LopezRaez, \& Pozo, 2012; Peña, Echeverría, Putten, Freitas, \& Moens, 2006; Smith \& Read, 2008). Thus, they can promote plant productivity and structure the plant community (Begum et al., 2019; Klironomos et al., 2011). Further, they improve the soil structure (Wilson, Rice, Rillig, Springer, \& Hartnett, 2009) and facilitate a range of fundamental ecosystem processes such as nitrogen, carbon and phosphorous cycling (Hodge \& Storer, 2015; Treseder, 2016; van der Heijden, Martin, Selosse, \& Sanders, 2015). Therefore, identifying the processes that drive AM diversity and community composition is important to understand changes in plant health and ecosystem nutrient cycling. While early studies on the AM community were mostly based on their macrospores in soil (Guadarrama \& Álvarez-Sánchez, 1999; Johnson, 1993; Oehl et al., 2010, 2003), advancement of next generation sequencing methods has enabled a much finer taxonomic resolution of the communities and the possibility to investigate basic ecologic concepts (Peay, Kennedy, \& Bruns, 2008; van der Heijden et al., 2015). Most AM show low global endemism (Davison et al., 2015) and can inhabit a wide range of host plants (Engelmoer \& Kiers, 2015). However, considerable differences in AM communities were found between grassland and forest AM communities on a global scale (Kivlin et al. 2011). Because AM inhabit two belowground habitats - plant roots and soil - their communities can be structured by soil abiotic drivers (Hazard et al., 2013) as well as vegetation structure and host plant identity (Rodríguez-Echeverría et al., 2017; Zobel \& Öpik, 2014).

Human land-use is an important driver of local biodiversity and community composition and can lead to biotic homogenization in a wide range of taxa, including the belowground microbiome (Epp Schmidt et al., 2017; Gossner et al., 2016; Newbold et al., 2015; Rodrigues et al., 2013, cf. chapter 2.2). Strong structuring effects of land-use on the AM community composition were frequently 
demonstrated for crop fields, pastures as well as temperate and savanna grasslands in soil and root associated communities (de León, Davison, et al., 2018; Moora et al., 2014; Sepp, Jairus, Vasar, Zobel, \& Öpik, 2018; Soka \& Ritchie, 2018; Tchabi et al., 2008; Vályi, Rillig, \& Hempel, 2015a). Molecular AM diversity is often reduced in intensively managed sites (Lumini, Orgiazzi, Borriello, Bonfante, \& Bianciotto, 2010; Moora et al., 2014; Verbruggen, van der Heijden, Weedon, Kowalchuk, \& Röling, 2012; Xiang et al., 2014). However, other studies showed no effects or even elevated AM diversity under management (Dai, Bainard, Hamel, Gan, \& Lynch, 2013; de León, Davison, et al., 2018; Sepp et al., 2018; Vályi et al., 2015). Compositional changes of the AM community were linked with management practices like fertilizer input (Borriello, Lumini, Girlanda, Bonfante, \& Bianciotto, 2012), usage of herbicides (Druille, Omacini, Golluscio, \& Cabello, 2013) and mechanical disturbance (de Pontes et al., 2017) in agricultural soils. AM fungi are usually dominant in tropical ecosystems (Steidinger et al., 2019) but studies investigating the effect of land transformation on the AM community in tropical forest systems are less frequent and the effects of land transformation remain understudied. Studies based on soil borne AM spores demonstrated significant compositional AM community changes between tropical old growth forests and agroforestry systems as well as pastures (Leal, Siqueira, \& Stürmer, 2013; Stürmer \& Siqueira, 2011). In contrast to those results, high resilience against forest slash and burn and conversion to pastures has recently been demonstrated for the spore and molecular AM community in soil (Carrillo-Saucedo, Gavito, \& Siddique, 2018; de León, Neuenkamp, et al., 2018). Thus, further research is required to characterize the effects of intensified tropical land-use on AM communities.

In South East Asia low-land rainforest has often been converted into mixed, disturbed agroforestry systems such as jungle rubber or replaced by long rotation monocultures such as oil palm (Elaeis guineensis) and rubber (Hevea brasiliensis). This land-use conversion in tropical forest ecosystems is responsible for a major proportion of forest loss (Vijay, Pimm, Jenkins, \& Smith, 2016). As a consequence, the vegetation structure is drastically altered since plantations only harbor a small fraction of the natural occurring plant and animal biodiversity (Barnes et al., 2017; Grass et al., 2020; Rembold, Mangopo, Tjitrosoedirdjo, \& Kreft, 2017). Land transformation also causes severe compositional changes in the soil fungal communities with reduced AM abundance (Brinkmann et al., 2019; Kerfahi, Tripathi, Dong, Go, \& Adams, 2016; McGuire et al., 2015). However, responses of soil borne and root associated AM communities to ecological drivers can differ because their recource allocation to intra- and extraradical structures (such as spores) may change between the soil an root habitat compartment (Stevens et al., 2020). For example, in oil palm plantations elevated spore abundance but reduced mycorrhizal colonization rates of roots were observed (Sahner et al., 2015). Studies investigating the effects of tropical land transformation on the root associated AM community are currently lacking. 
In the present study we used DNA sequencing, AM spore counts and mycorrhizal colonization of plant roots to access the root-associated AM diversity, abundance and community composition in jungle rubber, rubber and oil palm monocultures in comparison to low-land rainforest in Sumatra (Indonesia). We sampled these four land-use systems in two landscapes and in two sampling years $(2013,2016)$. For each land use system per landscape, we calculated a land-use intensity (LUI) index following the approach of Blüthgen et al. (2012). LUI incorporates fertilization, herbicide application, weeding, and plant diversity. Further, we used indicator species analysis to investigate the habitat specificity of AM. We hypothesized that (i) intensively managed sites show lower AM diversity and abundance because of a negative influence of LUI on root colonization. (ii) Land-use systems have a stronger structuring effect on the AM community than sampling year and landscape. (iii) The number of indicator species is higher in rain forest and jungle rubber than in rubber or oil palm plantations because of homogenization effects due to high LUI.

\section{Material and Methods}

\section{Study area}

The study area was located in the Indonesian province Jambi with a humid tropical climate (mean annual temperature $26.7^{\circ} \mathrm{C}$, mean annual precipitation $2235 \mathrm{~mm}$, short dry period usually from July to August). Large areas of naturally occurring rain forests in this region were subject to severe logging and replaced by rubber (Hevea brasiliensis) and oil palm (Elaeis guineensis) (Margono, Potapov, Turubanova, Stolle, \& Hansen, 2014; Rembold et al., 2017). Eight research plots (50x50 m) were established in each of four land-use systems: Protected rain forest $(F)$, rubber, planted in disturbed secondary forest referred to as jungle rubber $(\mathrm{J})$, monocultures of rubber $(\mathrm{R})$ or oil palm $(\mathrm{O})$. Four plots of each land-use type were located in each of two landscapes: Sarolangun Regency west of Jambi City, here referred to as "Bukit Landscape (B)" and Muaro Jambi Regency, south of Jambi City, here referred to as "Harapan Landscape $(\mathrm{H})$ ". Forest plots were located in the "PT Restorasi Ekosistem Indonesia" forest restoration project (Muaro Jambi Regency, Harapan landscape) and National Park Bukit Duabelas (Sarolangun Regency, Bukit landscape). All plots are located on tropical Acrisol soil but Bukit landscape is dominated by clay Acrisol, while Harapan is dominated by loamy Acrisol with lower organic carbon and total nitrogen content (Allen, Corre, Tjoa, \& Veldkamp, 2015). The plots were established in 2012 as part of the long term research project "Ecological and Socioeconomic Functions of Tropical Lowland Rainforest Transformation Systems" (EFForTS, www.uni-goettingen.de/EFForTS). For more detailed descriptions of the investigated sites, including geographic locations, climatic variation and vegetation see for example Drescher et al. (2016) and Rembold et al. (2017). 


\section{Root sampling}

Sampling took place in October to November in the years 2013 and 2016 preceding the yearly rainfall peaks in central Sumatra (Drescher et al., 2016). Because the plots BJ1, BJ2, and BO1 were replaced between the two sampling campaigns, those data were excluded from this study. In each plot three $5 \times 5 \mathrm{~m}$ subplots with a minimum distance of $15 \mathrm{~m}$ apart from each other were installed. Within each subplot five soil cores (15 $\mathrm{cm}$ depth and $4 \mathrm{~cm}$ diameter) were extracted after removing the surface litter. The five cores were pooled, resulting in a total of three samples per plot. Samples were sieved (50 x $50 \mathrm{~mm}$ mesh), roots were separated from soil and washed. Coarse roots were separated from fine roots ( $<2 \mathrm{~mm}$ diameter) and fine roots were immediately freeze dried (VirTis Bench Top K, SP Industries, Warminster, USA) and exported to University of Göttingen (Germany) for molecular analysis.

\section{Land-use intensity}

For each land-use system plot a land-use intensity index (LUI) was calculated following the approach of (Blüthgen et al., 2012; Sahner, 2016). The index represents the sum of several standardized components of LUI. Here we adapted the index originally designed for grasslands to account for four components: yield $(\mathrm{Y})$ in tons per ha and year, applied fertilizer $(\mathrm{F})$ in $\mathrm{kg}$ per ha and year, applied herbicides $(\mathrm{H})$, applied mechanical weeding (W) and plant species richness (S). Vascular plant species richness, recorded between 2013 and 2014, for each plot was obtained from Rembold et al. (2017). More recent data were not available at the time of this study but we did not assume significant plant community change within the plots over the course of two years. Management data ( $Y, F, H$, and $W$ ) were derived from monthly farmer inquiries between the years $2013-2016$ provided by the Central Scientific Service Group (Z02) of the EFForTS project (www.uni-goettingen.de/en/412114.html) and summed for each year. Estimated components can be found in Supplementary Table S 2.1.1. The equation for calculating the LUI is provided in Table 2.1.1 and LUI values for each plot for the years 2013 - 2016 can be found in Supplementary Table S 2.1.2. All components were standardized by dividing with its maximum value in each year ( $\mathrm{y}$ ) and landscape (I), thus giving each component a value between zero and one (Herzog et al., 2006). For yield, the maximum value of the respective crop (c) (rubber or oil palm) was used. Farmers applied a variety of different fertilizers and herbicides. Therefore, components $\mathrm{F}$ and $\mathrm{H}$ were divided into several subcomponents (F1 - F6 and $\mathrm{H} 1-\mathrm{H} 3$ ), classified according to substance groups. A definition of all components is given in Table 2.1.1. The sum of applied subcomponents was devided by the number of subcomponents to avoid giving higher weight to components with more subcomponents. While farmers stated the concentration of applied pesticide $[\mathrm{ml} / \mathrm{I}]$ in the questionnaires, total amount of applied pesticide was oftentimes unknown. Therefore, we counted the yearly number of pesticide applications and weighted each count with the given concentration. We also counted the number of occasions when 
mechanical weeding was applied. LUI components, in particular application of chemicals, are strongly depending on the individual financial situation of smallholder farmers as well as current market price. Thus, they vary strongly between years (Supplementary Table S 2.1.2). Mean LUI of the years 2013 and 2014 as well as 2015 and 2016 were therefore used, to better represent overall management intensity. Zero management was assumed for all forest plots and therefore, their LUI is only defined by plant diversity (Supplementary Table S 2.1.2)

Table 2.1.1 Equation to calculate land use intensity (LUI) for each plot and specification of measured LUI components

\begin{tabular}{|c|c|c|c|}
\hline & $\begin{array}{l}L U I_{i} \\
=\frac{Y_{i}}{\max \left(\left\{Y_{y, l, c}\right\}\right)} \\
+\frac{F 1_{i}}{\max \left(\left\{F 1_{y, l}\right\}\right)}\end{array}$ & $\frac{F 2_{i}}{\max \left(\left\{F 2_{y, l}\right\}\right)}+\frac{F 3_{i}}{\max \left(\left\{F 3_{y, l}\right\}\right)}$ & $\left.-\frac{F 4_{i}}{\max \left(\left\{F 4_{y, l}\right\}\right)}+\frac{F 5_{i}}{\max \left(\left\{F 5_{y, l}\right\}\right)}+\frac{F 6_{i}}{\max \left(\left\{F 6_{y, l}\right\}\right)}\right)$ \\
\hline & $+\underline{\left(\frac{H 1_{i}}{\max \left(\left\{H 1_{y, l}\right\}\right)}\right)}$ & $\frac{-\frac{H 2_{i}}{\max \left(\left\{H 2_{y, l}\right\}\right)}+\frac{H 3_{i}}{\max \left(\left\{H 3_{y, l}\right\}\right)}}{3}$ & $\frac{)^{6}}{6}+\frac{W_{i}}{\max \left(\left\{W_{y, l}\right\}\right)}+\left(1-\frac{S_{i}}{\max \left(\left\{S_{y, l}\right\}\right)}\right)$ \\
\hline & Type & Unit & Specification or Product \\
\hline $\mathrm{Y}$ & Yield & $\mathrm{kg} \mathrm{ha}^{-1} \mathrm{y}^{-1}$ & Fruit bunches or rubber latex \\
\hline F1 & Cow manure & $\mathrm{kg} \mathrm{ha} a^{-1} y^{-1}$ & - \\
\hline $\mathrm{F} 2$ & Urea & $k g h a^{-1} y^{-1}$ & - \\
\hline F3 & NPK & $\mathrm{kg} \mathrm{ha}^{-1} \mathrm{y}^{-1}$ & $16-16-16$ or ratio unknown \\
\hline F4 & Phosphate & $\mathrm{kg} \mathrm{ha}^{-1} \mathrm{y}^{-1}$ & $\begin{array}{l}\text { Rock phosphate; Triple Super Phosphate (TSP); Super } \\
\text { phosphate (SP-36) or product specification unknown }\end{array}$ \\
\hline F5 & $\mathrm{KCl}$ & $k g h a^{-1} y^{-1}$ & - \\
\hline F6 & Dolomite & $\mathrm{kg} \mathrm{ha}^{-1} \mathrm{y}^{-1}$ & $\mathrm{CaCO}_{3}(50-60 \%), \mathrm{MgCO}_{3}(35-40 \%)$ \\
\hline $\mathrm{H} 1$ & Gramoxone & $\mathrm{n}$ applications $*$ conc $\mathrm{y}^{-1}$ & $\begin{array}{l}\text { Active ingredient: Paraquat, Dichlorid; Company: } \\
\text { Syngenta (Basel, Switzerland) }\end{array}$ \\
\hline $\mathrm{H} 2$ & Gylphosate & $\mathrm{n}$ applications $*$ conc $\mathrm{y}^{-1}$ & $\begin{array}{l}\text { Active ingredient: Glyphosate; } \\
\text { Products: Roundup (Bayer, Leverkusen, Germany), } \\
\text { Babalss } 490 \text { SL (Sari Kersna Kimia, Jakarta, Indonsia) or } \\
\text { unspecified }\end{array}$ \\
\hline H3 & Ally & $\mathrm{n}$ applications $*$ conc $\mathrm{y}^{-1}$ & $\begin{array}{l}\text { Active ingredient: Methsulfuron - Methyl ; Company: } \\
\text { DuoPont (Wilmington, USA) }\end{array}$ \\
\hline W & weeding & $\mathrm{n}$ applications $\mathrm{y}^{-1}$ & mechanical \\
\hline $\mathrm{S}$ & Plant richness & per Plot & Data from Rembold et al. (2017) \\
\hline
\end{tabular}

$c=$ crop,$I=$ landscape,$y=$ year 


\section{Arbuscular mycorrhizal spores}

Soil samples from each subplot were send to the Institute Pertanian Bogor (Java, Indonesia) to analyze the arbuscular mycorrhizal spore abundance. Spores were isolated following the method of Gerdemann \& Nicolson (1963). In short, $20 \mathrm{~g}$ of soil was suspended in $500 \mathrm{ml}$ tap water and stirred for 10 minutes. Subsequently, the suspension was passed to three sieves $(250 \mu \mathrm{m}, 125 \mu \mathrm{m}$ and 63 $\mu \mathrm{m})$. Sieved material was centrifuged in a $50 \%$ water-sucrose solution at $900 \times \mathrm{g}$ for 2 minutes. The supernatant was rinsed on a $63 \mu \mathrm{m}$ sieve for 3 minutes and the filtrate was placed on gridded filter paper in a $90 \mathrm{~mm}$ Petri dish. AM spores were identified by morphologic features and counted under a binocular stereomicroscope (Olympus SZ61, Osaka, Japan). Spore counts per plot and sampling year are given in Supplementary Table S 2.1.2.

\section{Arbuscular mycorrhizal colonization rate}

About 25 fine root fragments (length of $1-2 \mathrm{~cm}$ ) were placed in $70 \%$ ethanol (Eppendorf micro tube $2 \mathrm{ml}$, Sarstedt, Nümbrecht, Germany) and exported to the University of Göttingen (Germany). The root segments were stained following the method of Vierheilig et al. (1998): Washed roots were briefly surface dried with tissue paper and subsequently bleached in $2 \mathrm{ml} 10 \%$ potassium hydroxide solution for $90 \mathrm{~min}$ at $90^{\circ} \mathrm{C}$. This step was repeated for very dark pigmented roots, if they were not sufficiently bleached after the first step. Subsequently roots were washed and stained in a vinegarink solution (10\% acetic acid, black ink (Sheaffer Skrip, Shelton, USA) and deionized water, $1: 1: 8$ ) for approximately 45 minutes at room temperature. Superfluous ink solution was washed off with deionized water and root fragments of $10 \mathrm{~mm}$ length were stored in lacto glycerol $(86 \%$ glycerol (Carl Roth, Karlsruhe, Germany), 80 \% lactic acid (Carl Roth, Karlsruhe, Germany) and deionized water, $1: 1: 1$ ) up to several weeks. For microscopic analysis, fragments were placed on slides with a drop of lacto glycerol and gently pressed with cover slides. Cover slides were sealed with colorless nail polish. Three slides containig a total of $10-20$ root fragments were prepared per sample. To determine mycorrhizal colonization of the roots the gridline intersection method was used (McGonigle et al. 1990). Slides were placed under a compound microscope (Axio Observer Z.1, Zeiss, Jena, Germany) at $400 \times$ magnification and a $100 \mu \mathrm{m}$ grid was created using the software AxioVision LE (Zeiss, Jena, Germany). Presence or absence of AM hyphae, arbuscules and vesicles was recorded for 120 - 200 grids per sample. The AM colonization was calculated as:

$$
\text { AM colonization }[\%]=\frac{\text { colonized } \text { intersects }}{\text { total intersects }} * 100
$$

The AM root colonization data for 2013 were obtained from Sahner et al., (2015). Data for each plot and both years are given in Supplementary Table S 2.1.2. 


\section{Arbuscular mycorrhizal community}

The molecular fungal community was accessed by amplification and sequencing if the fungal internal transcript spacer gene region 1 (ITS1). DNA was extracted from freeze dried root material and the ITS1 region was amplified using the primers ITS1f-KYO2 (Toju, Tanabe, Yamamoto, \& Sato, 2012) and ITS2 (White, Bruns, Lee, \& Taylor, 1990) with specific overhang adapters for Illumina sequencing (Nextera Transposase Adapter sequences, document number 1000000002694 v01, Illumina Inc., San Diego, USA). Identical procedures were performed for the 2013 and 2016 samples and the detailed reaction protocols are presented in the methods part of chapter 2.2 in this study as well as in Sahner (2016).

MiSeq Illumina sequencing with the MiSeq Reagent Kit v3 (Illumina Inc., San Diego, USA) was performed in the Göttingen Genomics Laboratory. Raw sequence reads from the sampling years 2013 and 2016 were combinded for the bioinformatic processing. The bioinformatic processing pipline resulting in the full OTU community matrix is explained in detail in the methods part of chapter 2.2.

The number of reads per OTU of the three subplots was aggregated to represent the plot community and only OTUs classified as fungi were retained in the dataset. The OTU table was normalized using the $g m p r$ () function of the package GMPR (Chen et al., 2018) in the statistical software R v. 3.6.1 (R Core Team, 2019) prior to further analysis. The normalized community matrix resulted in a total of approximately 4.8 million reads with 7003 OTUs (Supplementary Table S 2.1.3). A total of 190,080 reads (3.96 \%) with 550 OTUs $(7.85 \%)$ were assigned to Glomeromycota and resulted in the final community matrix (Supplementary Table S 2.1.4). For comparative analysis of OTU richness the nonnormalized data were rarified instead, as recommended by Chen et al., (2018). The minimum read number of 6099 was chosen and rarefaction was applied using the rrarfy() of the R package vegan v.2.5.6 (Oksanen et al., 2019). Approximatley 372,000 reads and 4470 fungal OTUs remained in the rarfied dataset (Supplementary Table S 2.1.5). In this data set, 16,702 reads (4.49\%) with 436 OTUs $(9.75 \%)$ were assigned to Glomeromycota. OTU richness of Glomermycota was calculated from this data for each plot (Supplementary Table S 2.1.2).

\section{Statistical analysis}

All statistical analyses were performed using the statistic software R v.3.6.1 (R Core Team, 2019). Effects of land-use systems (forest, junglerubber, rubber, oil palm) on AM richness (OTUs) was tested using a generalized linear model (GLM), assuming a negative binomial distribution, as implemented by the function $\mathrm{g} / \mathrm{m} . \mathrm{nb}($ ) from the package MASS (Venables \& Ripley, 2002). Landscape (Bukit, Harapan) was included as fixed effect. Two separate models were constructed for the years 2013 and 2016 to avoid pseudo replication. In each model we tested the effect of landscape and land-use on 
the AM diversity using the Anova() function of the package car (Fox \& Weisberg, 2019). P-values < 0.05 were considered significant. The same models were applied for AM molecular abundance (read counts) and AM spore abundance (counts). The effect of land use system on AM mycorrhization in roots (colonized vs. non-colonized grid cells) was tested using a GLM with a binomial distribution as implemented in the $\mathrm{g} / \mathrm{m}()$ function of the stats package (R Core Team, 2019). Individual effects of each land-use system for all models were compared using post-hoc pair wise comparisons as implemented in the glht() function of the multcomp package (Hothorn et al. 2008).

GLMs were constructed to analyze the relation between LUI and AM diversity, abundance, spores as well as root mycorrhization. Again, separate models were constructed for the years 2013 and 2016 and landscape was included as fixed effect in all models.

Effects of land-use system on the AM community composition was analyzed by calculating pair wise Bray-Curtis community dissimilarity and applying non-metric multidimensional scaling (NMDS) as implemented in the function metaMDS() of the vegan package (Oksanen et al. 2019). Vegan's envfit() function with 999 permutations was used to test the correlation of LUI with NMDS axis. Permutation was restricted to sampling year. Significant effect of land-use system on the community composition was tested for both years seperately using PERMANOVA with 999 permutations as implemented in vegan's adonis() function. Permutation was restricted to landscape using the strata argument.

Association of individual glomeromycete OTUs with land-use systems was visualized using a bipartite networks as implemented in the function plotweb() of the bipartite package (Dormann, Fründ, Blüthgen, \& Gruber, 2009). Networks were plotted for each sampling year separately. Numbers of reads per OTU in each land-use system were considered as abundance and only OTUs with a total relative abundance $>0.1 \%$ of all AM reads were used. To identify OTUs significantly associated with one of the land-use systems, indicator species analysis (Dufrene \& Legendre, 1997) was performed, using function multipatt() with 9999 permutations as implemented in indicspecies (de Cáceres \& Legendre, 2009). All p-values were corrected for multiple comparisons using False Discovery Rate (Benjamini \& Hochberg, 1995). 


\section{Results}

Rarfied OTU richness ranged from 0 - 99 across all research plots and both sampling times (Table 2.1.2). We found a roughly tenfold higher abundance of $A M$ reads as well as $A M$ spores in sampling year 2016 than in 2013 (Table 2.1.2). However, the effects of land-use systems on OTU richness, abundance, AM spore abundance and AM root colonization were similar in both years (Table 2.1.2, Figure 2.1.1). AM richness in jungle rubber was similar to that in forest roots (Figure 2.1.1 A, B). The roots in rubber plantations showed reduced species richness compared to forest roots in 2013 but no significant difference was observed in 2016 (Figure 2.1.1 A, B). AM richness was lower in oil palm roots compared to forest roots in both years (Figure 2.1.1 A, B). Similarly, AM abundance was higher in forest and jungle rubber roots than in monocultures. Notably, AM abundance was lower in roots of oil palm than in roots of rubber plantations (Figure 2.1.1 C, D), a reversed trend was observed in AM spore abundances, which were higher in the plantations than in forest soils (Figure 2.1.1 E, F). Fine root AM mycorrhization was reduced in oil palm plantations compared to all other land use systems (Figure 2.1.1 G, H).

Table 2.1.2 Generalized linear model (GLM) fits for AM richness, abundance (reads), spore counts and root colonization (\%) in relation to landscape and land-use system using $\chi^{2}$ - test. Range of measured variables in the sampling years 2013 and 2016 is given. $\mathbf{N}=$ sample size, $\mathbf{d f}=$ degrees of freedom, $\chi^{2}=$ Chi-square statistic, $p=p$-value

\begin{tabular}{|c|c|c|c|c|c|c|c|c|c|c|c|}
\hline \multirow[b]{2}{*}{ Response } & \multirow[b]{2}{*}{ Predictor } & \multicolumn{5}{|c|}{2013} & \multicolumn{5}{|c|}{2016} \\
\hline & & $\mathrm{N}$ & $d f$ & $\chi^{2}$ & $p$ & range & $\mathrm{N}$ & $d f$ & $\chi^{2}$ & $p$ & range \\
\hline \multirow{2}{*}{$\begin{array}{l}\text { OTU } \\
\text { richness }\end{array}$} & Landscape & 29 & 1 & 1.01 & 0.316 & \multirow{2}{*}{$0-67$} & 32 & 1 & 3.56 & 0.059 & \multirow{2}{*}{$29-99$} \\
\hline & land-use & 29 & 3 & 11.58 & 0.009 & & 32 & 3 & 27.25 & $<0.001$ & \\
\hline \multirow{2}{*}{$\begin{array}{l}\text { OTU } \\
\text { abundance }\end{array}$} & Landscape & 29 & 1 & 0.02 & 0.898 & $0-$ & 32 & 1 & 9.00 & 0.003 & $605-$ \\
\hline & land-use & 29 & 3 & 9.65 & 0.022 & 1616 & 32 & 3 & 39.03 & $<0.001$ & 13371 \\
\hline \multirow{2}{*}{ AM spores } & Landscape & 27 & 1 & 0.17 & 0.685 & \multirow{2}{*}{$3-108$} & 32 & 1 & 0.46 & 0.498 & $88-$ \\
\hline & land-use & 27 & 3 & 54.04 & $<0.001$ & & 32 & 3 & 23.16 & $<0.001$ & 1220 \\
\hline AM & Landscape & 27 & 1 & 13.68 & $<0.001$ & $40-93$ & 29 & 1 & 3.54 & 0.059 & $32-80$ \\
\hline colonization & land-use & 27 & 3 & 68.41 & $<0.001$ & $\%$ & 29 & 3 & 437.8 & $<0.001$ & $\%$ \\
\hline
\end{tabular}



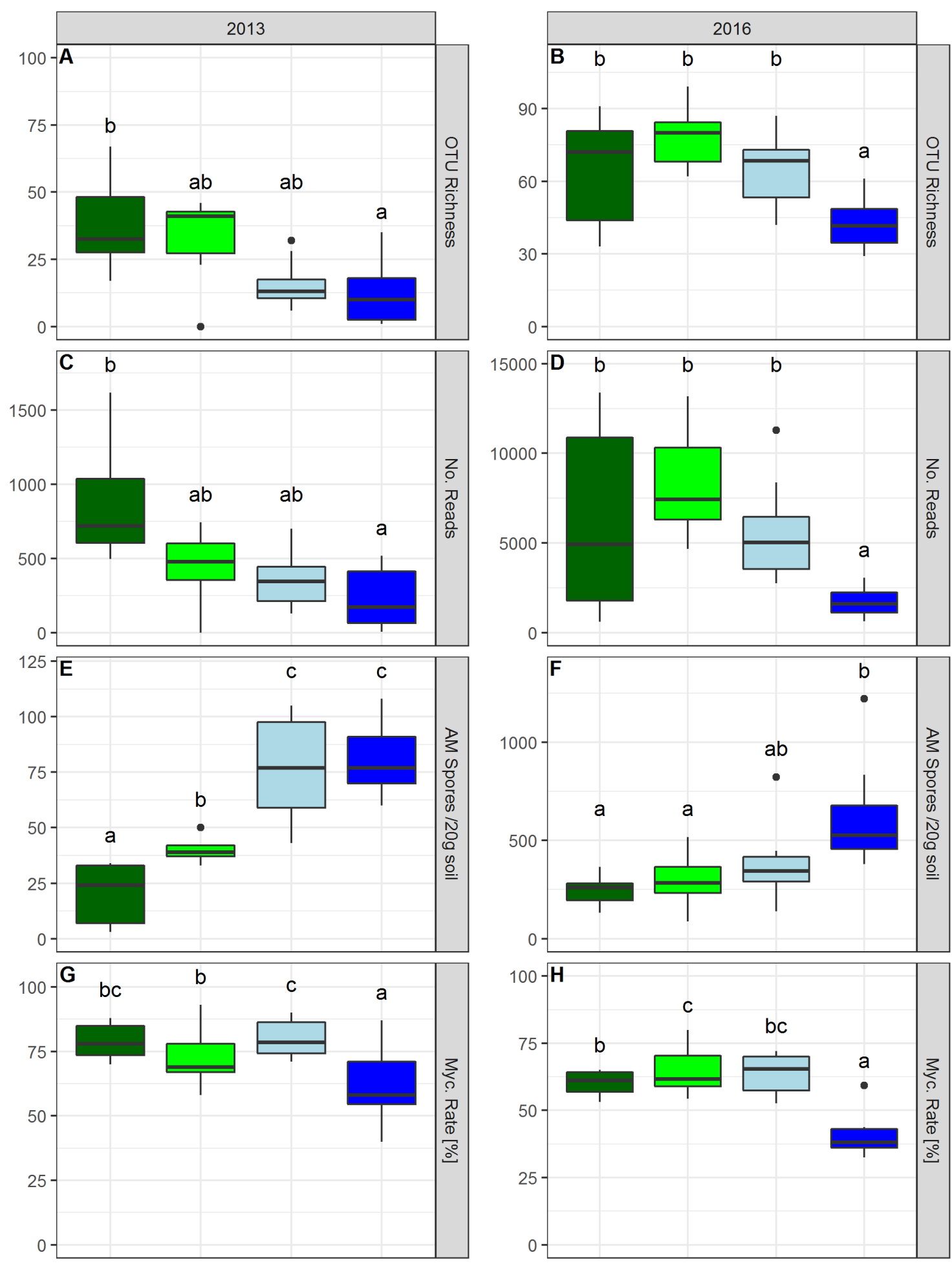

forest

oilpalm

Figure 2.1.1 OTU richness (A, B), number of reads $(C, D)$, spore numbers $(E, F)$ and mycorrhizal root colonization (G, H) of arbuscular mycorrhizal fungi (AM) in the years 2013 (left) and 2016 (right). The effect of land-use systems was tested using generalized linear models and significant Tukey contrasts of multiple comparisons at $p<0.05$ are denoted by letters a - c. 
Generalized linear models (GLM) were constructed to estimate the effect of LUI on AM richness, abundance, spore abundance and root colonization (Table 2.1.3, Figure 2.1.2). GLMs revealed a strong negative effect of LUI on AM richness and abundance in both sampling years (Figure 2.1.2 A D). Spore abundance was increased with higher LUI (Figure 2.1.2 E, F), while root mycorrhiza colonization decreased (Figure 2.1.2 G, H).

Table 2.1.3 Generalized linear models (GLM) showing the effect of land-use intensity (LUI) and plant diversity on arbuscular mycorrhizal fungi OTU richness, abundance, spore abundance and root mycorrhization rate. Landscape was included as fixed effect. Coefficient estimates (Est.) significantly differing from zero are highlighted. $S E=$ standart error of the estimate, $Z=z$-score, $p=$ p-value

\begin{tabular}{|c|c|c|c|c|c|c|c|c|c|}
\hline \multirow[b]{2}{*}{ Response } & \multirow[b]{2}{*}{ Predictor } & \multicolumn{4}{|c|}{2013} & \multicolumn{4}{|c|}{2016} \\
\hline & & Est. & SE & Z & $\mathrm{p}$ & Est. & SE & Z & $\mathrm{p}$ \\
\hline OTU & landscape & -0.187 & 0.288 & -0.65 & 0.516 & 0.109 & 0.099 & 1.11 & 0.268 \\
\hline Richness & LUI & -0.337 & 0.132 & -2.85 & 0.011 & -0.203 & 0.060 & -3.37 & $<0.001$ \\
\hline OTU & landscape & 0.059 & 0.348 & 0.17 & 0.865 & 0.314 & 0.234 & 1.34 & 0.180 \\
\hline Reads & LUI & -0.346 & 0.158 & -2.19 & 0.029 & -0.550 & 0.141 & -3.89 & $<0.001$ \\
\hline \multirow[t]{2}{*}{ Spores } & Landscape & -0.237 & 0.204 & -1.16 & 0.246 & 0.222 & 0.090 & 1.49 & 0.135 \\
\hline & LUI & 0.392 & 0.090 & 4.33 & $<0.001$ & 0.435 & 0.435 & 4.85 & $<0.001$ \\
\hline \multirow[t]{2}{*}{ Myc. Rate } & Landscape & -0.275 & 0.091 & -3.02 & 0.003 & -0.217 & 0.041 & -5.21 & $<0.001$ \\
\hline & LUI & -0.196 & 0.039 & -4.99 & $<0.001$ & -0.365 & 0.025 & -14.48 & $<0.001$ \\
\hline
\end{tabular}



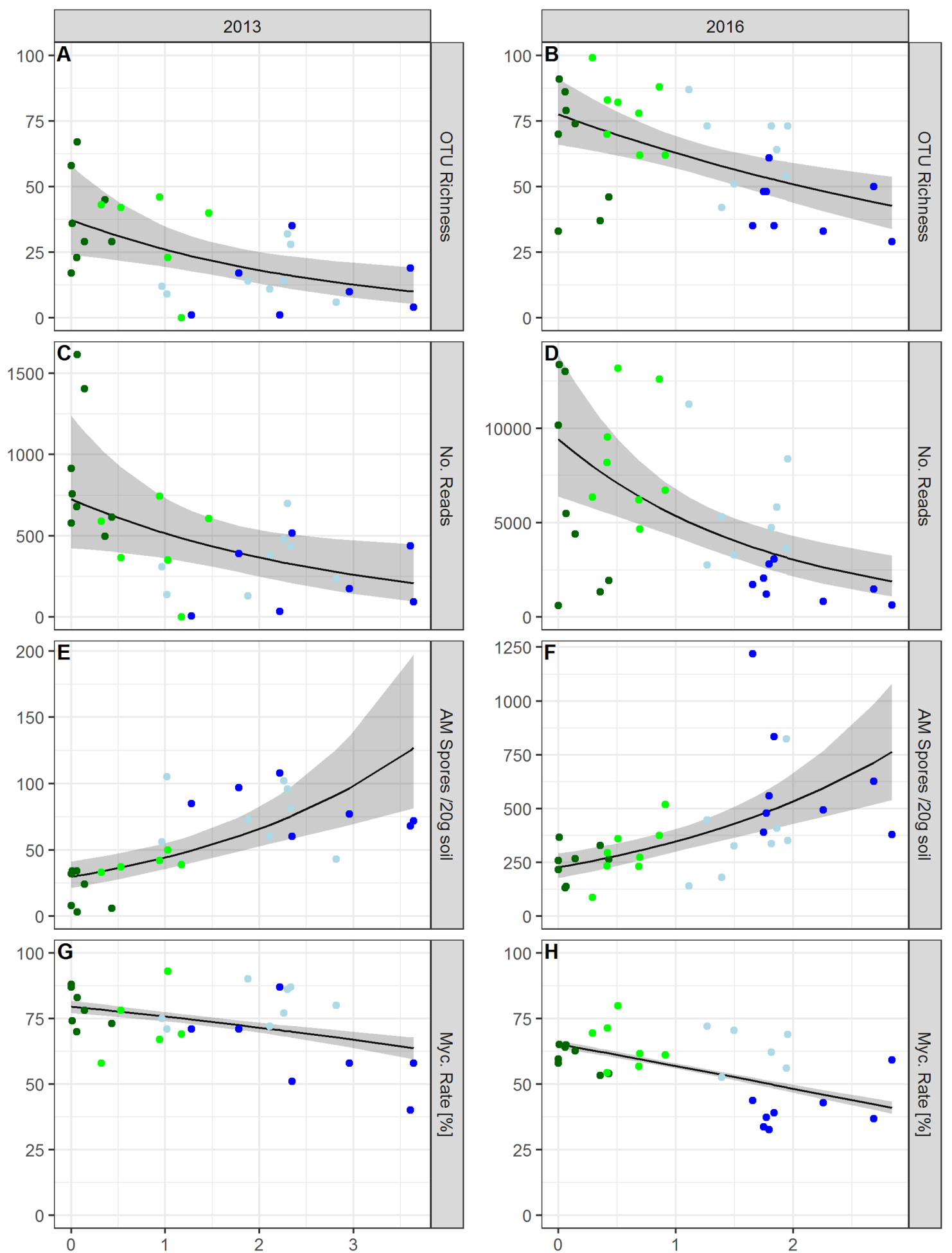

forest junglerubber

Figure 2.1.2 OTU richness $(A, B)$, read abundance $(C, D)$, spore numbers $(E, F)$ and mycorrhizal root colonization (G, H) of arbuscular mycorrhizal fungi (AM) in the years $2013(A, C, E, G)$ and 2016 $(B, D, F, H)$ in relation to land-use intensity (LUI). Black lines represent generalized linear model fits with $95 \%$ confidence intervals (grey area). 
We found considerable compositional differences between the AM communities sampled in 2013 and 2016 (PERMANOVA: pseudo- $F_{1,58}=7.85, p<0.001, R^{2}=0.12$ ). However, in both years we found strong structuring effects by land-use system on the AM community composition (PERMANOVA 2013: pseudo- $F_{3,23}=2.804, p<0.001, R^{2}=0.257 ; 2016:$ pseudo- $\left.F_{3,27}=3.261, p<0.001, R^{2}=0.297\right)$. The effects were confirmed by ordination of the community data matrix using non-metric multidimensional scaling (NMDS). Ordination axes were significantly correlated with LUI (Figure 2.1.3).

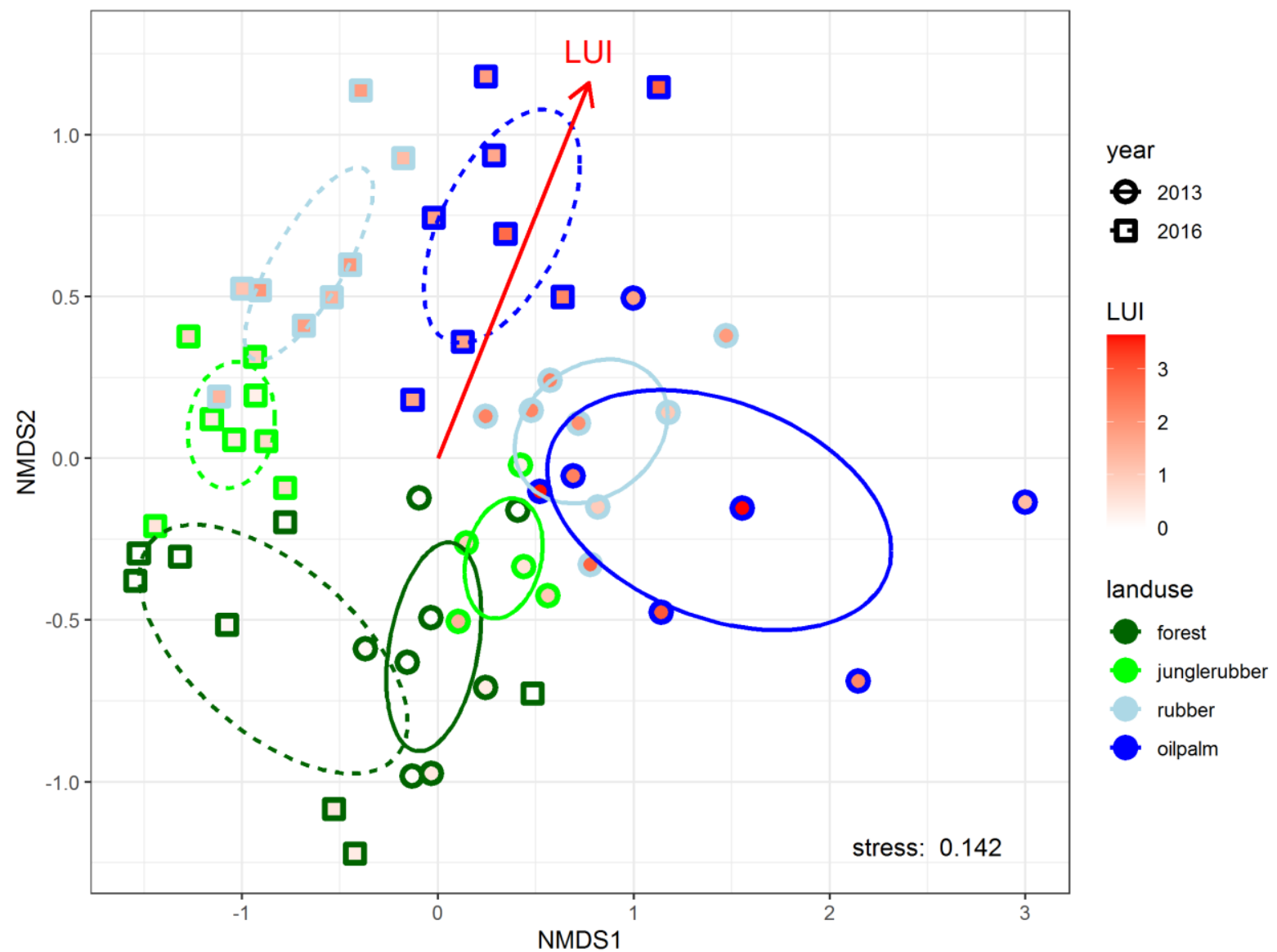

Figure 2.1.3 Non-metric multidimensional scaling (NMDS) of the arbuscular mycorrhizal fungal community based on Bray-Curtis dissimilarity. Ellipses represent standard errors from the centroid of each land-use system and year. Red arrow denotes the correlation between land-use intensity (LUI) and ordination axes. 
We further investigated the association of individual OTUs with land-use systems to analyze the specificity of AM towards undisturbed forests versus intensively managed plantations. Only OTUs with a minimum abundance of $>0.1 \%$ of all AM reads per sampling year were included, resulting in 154 OTUs in 2013 and 133 OTUs in 2016 accounting for $93.1 \%$ and $91.2 \%$ of AM reads, respectively. The majority of OTUs were present in all land-use systems (Figure 2.1.4 A, B). However, bipartite networks show that the decline in the abundance of $A M$ in plantations and the community compositional shift were linked to a decline of OTUs frequently present in forest or extensively managed jungle rubber (Figure 2.1.4 C, D). Few OTUs showed increased abundance in plantation sites (Figure 2.1.4 C, D). To test the association of OTUs with a land-use system, we used indicator species analysis (Dufrene \& Legendre, 1997). Despite the strong overlap of OTU occurrences across land-use systems (Figure 2.1.4 A, B) we dected a total of 13 and 36 indicator species in the years 2013 and 2016, respectively (Table 2.1.4). Seven of those indicators were occurring in both sampling years. Notably, we found a higher number of indicators in forest and jungle rubber plots than in monoculture plantations (Table 2.1.4, Figure 2.1.4 B, C). 
A 2013

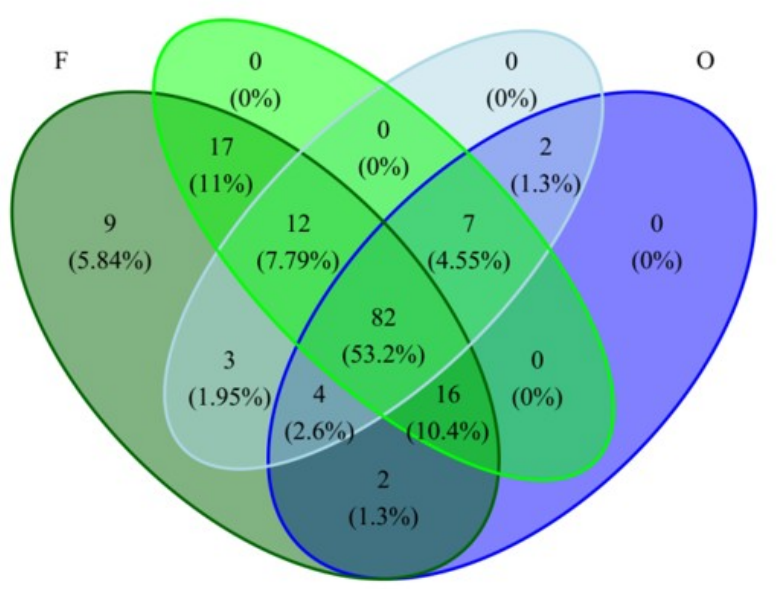

B

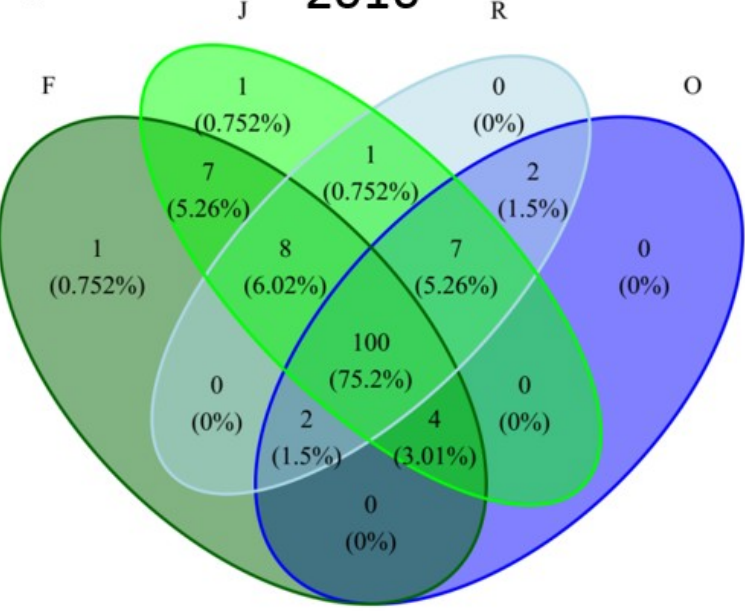

$\mathrm{C}$

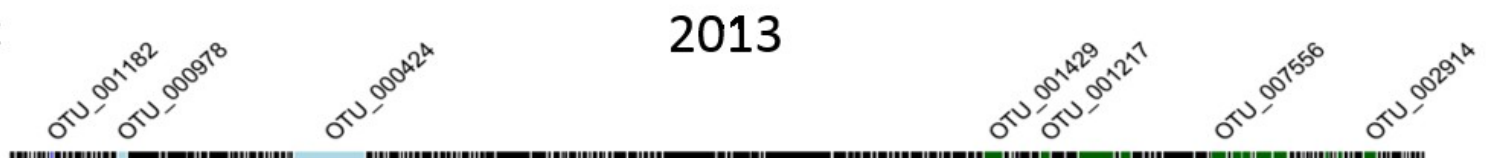

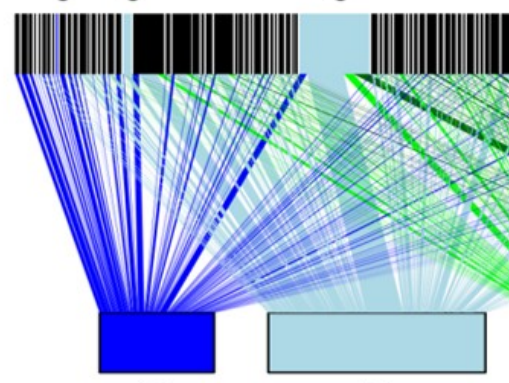

$\mathrm{O}$

$\mathrm{R}$

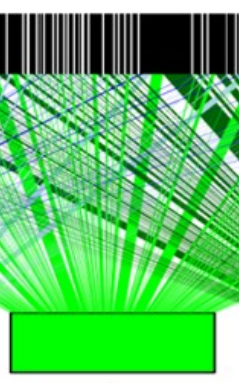

$J$

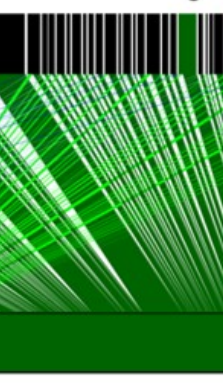

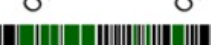

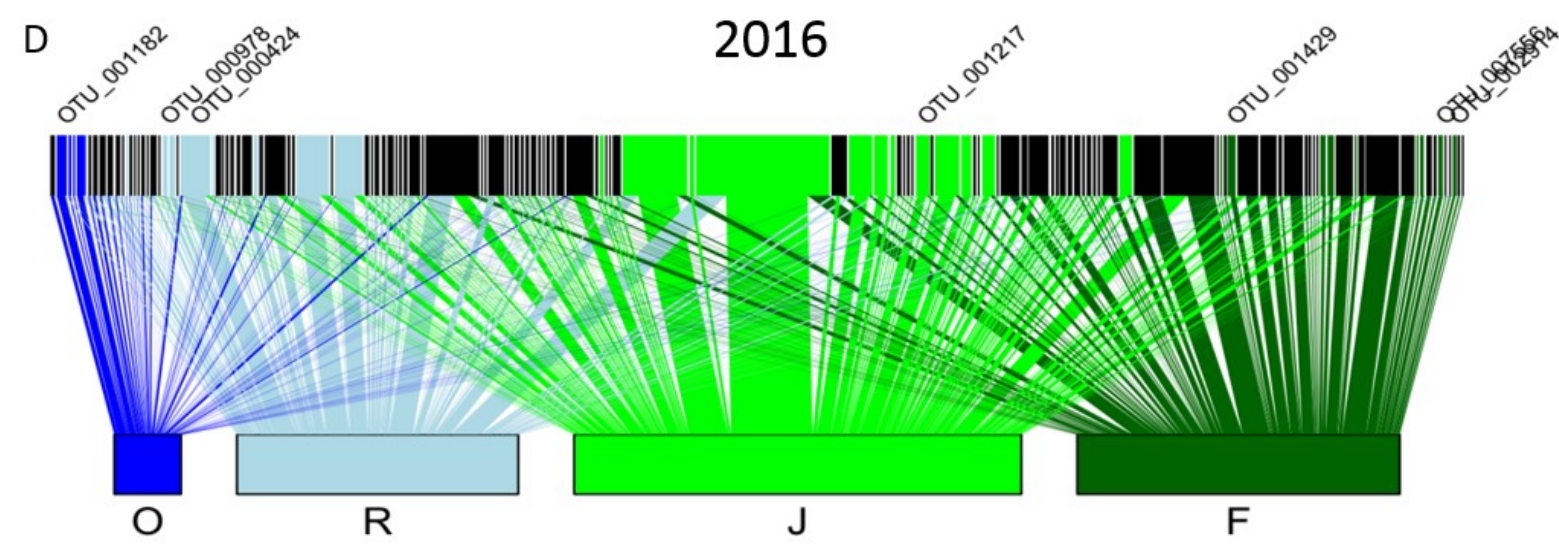

Figure 2.1.4 A, B: Number of shared and unique arbuscular mycorrhizal (AM) fungi OTUs in four land-use systems forest (F), jungle rubber (J), rubber (R), oil palm (O) in the years 2013 and 2016. C, D: Association of individual OTUs with land-use systems. Boxes on the top represent OTUs, while boxes on the bottom represent the land-use systems. Box and line width represents the relative abundance of OTUs, derived from counts of molecular DNA reads. OTUs significantly associated with an individual land-use system according to indicator species analysis are highlighted in the respective color sceme. 
Table 2.1.4 Indicator species found in sampling years 2013 and 2016, associated to respective landuse systems

\begin{tabular}{|c|c|c|c|}
\hline Land-use System & ID & Year & Taxonomy \\
\hline forest & OTU_000450 & 2013 & Septoglomus \\
\hline forest & OTU_000842 & 2013 & Glomeraceae \\
\hline forest, jungle rubber & OTU_001217 & 2013,2016 & Glomeraceae \\
\hline forest & OTU_001229 & 2013 & Glomeraceae \\
\hline forest & OTU_001429 & 2013,2016 & Glomeromycota \\
\hline forest & OTU_001672 & 2013 & Glomeraceae \\
\hline forest & OTU_002914 & 2013,2016 & Glomeraceae \\
\hline forest & OTU_003371 & 2013 & Glomeraceae \\
\hline forest & OTU_007556 & 2013,2016 & Glomeromycota \\
\hline forest & OTU_010807 & 2013 & Glomeraceae \\
\hline forest & OTU_002250 & 2016 & Glomeraceae \\
\hline forest & OTU_003518 & 2016 & Glomeromycota \\
\hline forest & OTU_003596 & 2016 & Glomeromycota \\
\hline forest & OTU_004075 & 2016 & Glomeraceae \\
\hline forest & OTU_004653 & 2016 & Glomeromycota \\
\hline forest & OTU_005122 & 2016 & Glomeraceae \\
\hline forest & OTU_006290 & 2016 & Glomeromycota \\
\hline forest & OTU_006909 & 2016 & Gigasporaceae \\
\hline jungle rubber & OTU_000082 & 2016 & Glomeraceae \\
\hline jungle rubber & OTU_000116 & 2016 & Glomeraceae \\
\hline jungle rubber & OTU_000257 & 2016 & Glomeraceae \\
\hline jungle rubber & OTU_000553 & 2016 & Glomeraceae \\
\hline jungle rubber & OTU_000686 & 2016 & Glomeraceae \\
\hline jungle rubber & OTU_001398 & 2016 & Glomeraceae \\
\hline jungle rubber & OTU_001428 & 2016 & Glomeromycota \\
\hline jungle rubber & OTU_001604 & 2016 & Glomeraceae \\
\hline jungle rubber & OTU_002242 & 2016 & Glomeromycota \\
\hline jungle rubber & OTU_002361 & 2016 & Glomeromycota \\
\hline jungle rubber & OTU_003108 & 2016 & Glomeraceae \\
\hline jungle rubber & OTU_003415 & 2016 & Glomeraceae \\
\hline rubber & OTU_000424 & 2013,2016 & Glomerales \\
\hline rubber & OTU_000489 & 2016 & Glomeraceae \\
\hline rubber & OTU_000757 & 2016 & Glomeraceae \\
\hline rubber & OTU_000784 & 2016 & Glomeraceae \\
\hline rubber & OTU_000978 & 2013,2016 & Glomeraceae \\
\hline rubber & OTU_001629 & 2016 & Glomeraceae \\
\hline rubber & OTU_002967 & 2016 & Glomeraceae \\
\hline rubber & OTU_003683 & 2016 & Rhizophagus \\
\hline rubber & OTU_005332 & 2016 & Acaulospora \\
\hline oil palm & OTU_001182 & 2013,2016 & Glomerales \\
\hline oil palm & OTU_000684 & 2016 & Glomerales \\
\hline oil palm & OTU_005031 & 2016 & Glomeraceae \\
\hline oil palm & OTU_007303 & 2016 & Acaulospora \\
\hline
\end{tabular}




\section{Discussion}

In this study for the first time, we comprehensively assess AM diversity and community composition in roots across multiple plantation systems and tropical rainforests in Southeast Asia. We show a reduction of AM diversity and abundance in monoculture plantations compared to forest and extensively managed jungle rubber. In line with studies analyzing the overall soil fungal community including Basidio- and Ascomycetes (Brinkmann et al., 2019; Kerfahi et al., 2016; McGuire et al., 2015), we found distinct community assemblies of root associated AM fungi in all four land usesystems. We present evidence that the diversity loss and AM community shift is driven by increased LUI and show a decline of AM associated with forest habitats, suggesting a favorable selection of few generalist species under elevated LUI.

To analyze the AM community in the present study we used general fungal primers to amplify the fungal internal transcript spacer (ITS) marker gene (Schoch et al., 2012). Most studies addressing AM communities, use specifically designed primers to amplify the small subunit (SSU) rRNA gene of Glomeromycota (Öpik et al. 2010; Kivlin et al. 2011; Öpik et al. 2013). Primers targeting the ITS have been critizezed to distorted the true proportional abundance between fungal phyla (Asco-, Basidiomycota versus 'non-dicarya' such as Glomeromycota; Bellemain et al., 2010; Lindahl et al., 2013) and a primer bias in our study can thus not be ruled out. However, recent studies, comparing primer bias of AM specific and general fungal primers, demonstrate that both were capable in detecting general ecological responses of AM communities (Berruti, Desirò, Visentin, Zecca, \& Bonfante, 2017; Lekberg et al., 2018). In this study we did not address phylogenetic or taxonomic aspects of the AM community, for which the used primers are not suited.

Supporting our initial hypothesis we found reduced AM richness and reduced AM abundance with increasing LUI. Oil palm as well as rubber monocultures have a strongly reduced plant richness compared to forest or junglerubber (Rembold et al., 2017). However, the decrease in AM richness and abundance was stronger in oil palm roots than in the roots of other systems. This finding might indicate that management practices, not plant diversity are the main driver for AM richness and colonization. In support, no change in AM diversity after clear cutting or slash-and-burn of tropical forest was recently demonstrated (de León, Neuenkamp, et al., 2018), suggesting no direct link between AM and plant diversiy. Besides plant richness, LUI was linked to fertilizer and herbicide inputs in our study. We speculate that elevated fertilizer inputs in the oil plam plots compared to other plots in particular drove the AM community. Sheldrake et al. (2018) showed that organic and non-organic nutrient addition resulted in reduced richness and abundance of AM in tropical forests. Readily available nutrient input by fertilization may cause reduced plant investment in their 
mycorrhizal partners (Bennett \& Bever, 2009; Treseder, 2004) and hence, contribute the observed reduction of the AM abundance and diversity in plots with high LUI.

In line with previous results (Sahner et al., 2015) we observed increased number of spores with increased LUI. Fungal spores are not only propagules in soil but in many species additionally serve as a resting stage to survive unfavorable conditions (Wyatt, Wösten, \& Dijksterhuis, 2013). For example, strong correlation between increased $\mathrm{pH}$ and $\mathrm{AM}$ spore abundance has been observed in temperate agricultural soils (Oehl, Laczko, Oberholzer, Jansa, \& Egli, 2017). In our study soil pH was increased in monoculture plots, especially oil palm (Allen et al., 2015; Brinkmann et al., 2019). Thus, intensive land-use and changes in soil chemistry may cause increased AM resting spore production as a response to environmental stress. Furthermore, antagonistic fluctuation of AM spore abundance and AM root colonization rates have previously been observed in tropical forests (Louis \& Lim, 1987), thus elevated spore abundance in intensively managed plots might be related to reduced colonization. Our findings agree with previous results from tropical regions in the Brazilian Amazonas, where higher AM spore abundancse were observed in pastures, crops and agroforestry systems compared to pristine forests (Stürmer \& Siqueira, 2011). At variance with those results, decline of AM spore abundance with intensified land-use was observed in temperate grasslands (Oehl et al., 2010; Zhang, Yang, Guo, \& Guo, 2016) as well as sub-tropical savannas (Soka \& Ritchie, 2018; Tchabi et al., 2008). Increased spore abundance could also indicate selection of life history traits by land-use systems (Sahner et al., 2015) but due to the limited knowledge on taxonomy and functional traits of AM OTUs found in this study, answering this question is beyond our scope. Experimental studies altering the land-use intensity by e.g. changing amounts of fertilizer input are required to identify the drivers of AM spore abundance under land-use conditions.

To supplement our molecular data we analyzed the mycorrhization rates of the plant root community. Our results are in line with previous studies observing negative impact of land-use on mycorrhization rates (Li et al. 2007; Sonnemann et al. 2016). However, reduction of AM root colonization was not as strong as loss of molecular AM diversity and abundance in our study. Thus, we speculate that loss of AM diversity benefits those AM species that are able to successfully colonize plant roots under high LUI.

Regardless of the landscape we found distinct AM community assemblies within all four land-use systems. This is in agreement with a multitude of other studies, mainly from grassland habitats, that confirm significant differences in the AM community composition between land-use types (Borriello et al., 2012; Moora et al., 2014; Oehl et al., 2017; Sepp et al., 2018; Xiang et al., 2014). Furthermore, our results show that compositional changes were associated with increased LUI. Community shift driven by LUI often causes biotic homogenization due to the loss of specialist species with a narrow 
ecological niche and replacement by generalists able to successfully colonize disturbed ecosystems (Gossner et al., 2016). An alternative possibility is that monocultures could lead to a specialist AM community adapted to the available host plant (Vályi et al. 2015). In our study, most OTUs were present in all land-use systems and none was exclusively associated with one of the monocultures, thus, supporting our hypothesis that LUI, not host specific selection drives AM community composition. In line with our observations, host specific selection of AM species was neiter demonstrated in roots of various forest trees nor in roots of oil palm and rubber (Edy, 2015). Nevertheless, bipartite association networks showed strong abundance shifts of individual OTUs across land-use systems. We demonstrated decreasing abundances of multiple OTUs occurring in forest and junglerubber plots towards plantation sites, while few OTUs were favored in monocultures. Indicator species analysis was used to explore significant associations between landuse types and AM OTUs (de Cáceres \& Legendre, 2009). The analysis predicts the strength of the link between a species and a certain habitat and thus, an indicator species can been viewed as a habitat specialist (Chai et al., 2019). We found the lowest number of indicator species for intensively managed oil palm plantations while a higher number was associated with either junglerubber or forest sites. Together these results indicate that LUI impairs the interaction between plants and a majority of naturally occurring AM, favouring few 'generalist' species and driving homogenization. In support, high nutrient input had a strong structuring effect on grassland and crop AM communities, overruling plant specific selection mechanisims, detected at low LUI (Gosling et al. 2013; Vályi et al. 2015). To our knowledge no studies so far addressed the selection of generalist and specialist AM fungi in tropical land-use systems, however, a preferred selection of generalist Basidio- and Ascomycota in pastures compared to forest was demonstrated in the Amazonas region (Mueller, Rodrigues, Nüsslein, \& Bohannan, 2016).

Reduction of diversity and abundance as well as loss of natural occurring AM fungal community can significantly affect overall soil health and may cause negative plant soil feedbacks reducing the overall plant performance (Frąc, Hannula, Bełka, \& Jędryczka, 2018).We show that land use intensity is an important driver for land-transformation induced changes in the AM community. Extensive and sustainable management therefore is likely to counteract negative effects on the AM community and improve overall ecosystem performance in tropical land-use systems. Our research provides valuable new knowledge on the assembly and driving mechanisms of AM root communities from currently understudied land-use systems. Experimental manipulation of LUI within the land-use systems by e.g. altering fertilizer and pesticide inputs are needed to identify recommendable management practices. 


\section{Literature}

Allen, K., Corre, M. D., Tjoa, A., \& Veldkamp, E. (2015). Soil nitrogen-cycling responses to conversion of lowland forests to oil palm and rubber plantations in Sumatra, Indonesia. PLOS ONE, 10(7), e0133325. doi: 10.1371/journal.pone.0133325

Barnes, A. D., Allen, K., Kreft, H., Corre, M. D., Jochum, M., Veldkamp, E., Clough, Y., Daniel, R., Darras, L., Denmead, L. H., Haneda, N. F., Hertel, D., Knohl, A., Kotowska, M. M., Kurniawan, S., Meijide, A., Rembold, K., Prabowo, W. E., Schneider, D., Tscharntke, T., \& Brose, U. (2017). Direct and cascading impacts of tropical land-use change on multi-trophic biodiversity. Nature Ecology \& Evolution, 1(10), 1511-1519. doi: 10.1038/s41559-017-0275-7

Begum, N., Qin, C., Ahanger, M. A., Raza, S., Khan, M. I., Ashraf, M., Ahmed, N., \& Zhang, L. (2019). Role of arbuscular mycorrhizal fungi in plant growth regulation: Implications in abiotic stress tolerance. Frontiers in Plant Science, 10. doi: 10.3389/fpls.2019.01068

Bellemain, E., Carlsen, T., Brochmann, C., Coissac, E., Taberlet, P., \& Kauserud, H. (2010). ITS as an environmental DNA barcode for fungi: An in silico approach reveals potential PCR biases. BMC Microbiology, 10(1), 189. doi: 10.1186/1471-2180-10-189

Benjamini, Y., \& Hochberg, Y. (1995). Controlling the false discovery rate: A practical and powerful approach to multiple testing. Journal of the Royal Statistical Society. Series B (Methodological), 57(1), 289-300.

Bennett, A. E., \& Bever, J. D. (2009). Trade-offs between arbuscular mycorrhizal fungal competitive ability and host growth promotion in Plantago lanceolata. Oecologia, 160(4), 807-816. doi: 10.1007/s00442-0091345-6

Berruti, A., Desirò, A., Visentin, S., Zecca, O., \& Bonfante, P. (2017). ITS fungal barcoding primers versus $18 \mathrm{~S}$ AMF-specific primers reveal similar AMF-based diversity patterns in roots and soils of three mountain vineyards. Environmental Microbiology Reports, 9(5), 658-667. doi: 10.1111/1758-2229.12574

Blüthgen, N., Dormann, C. F., Prati, D., Klaus, V. H., Kleinebecker, T., Hölzel, N., Alt, F., Boch, S., Gockel, S., Hemp, A., Müller, J., Nieschulze, J., Renner, S. C., Schöning, I., Schumacher, U., Socher, S., Wells, K., Birkhofer, K., Buscot, F., Oelmann, Y., Rothenwöhrer, C., Scherber, C., Tscharntke, T., Weiner, C. N., Fischer, M., Kalko, E. K. V., Linsenmair, K. E., Schulze, E.-D., \& Weisser, W. W. (2012). A quantitative index of land-use intensity in grasslands: Integrating mowing, grazing and fertilization. Basic and Applied Ecology, 13(3), 207-220. doi: 10.1016/j.baae.2012.04.001

Borriello, R., Lumini, E., Girlanda, M., Bonfante, P., \& Bianciotto, V. (2012). Effects of different management practices on arbuscular mycorrhizal fungal diversity in maize fields by a molecular approach. Biology and Fertility of Soils, 48(8), 911-922. doi: 10.1007/s00374-012-0683-4

Brinkmann, N., Schneider, D., Sahner, J., Ballauff, J., Edy, N., Barus, H., Irawan, B., Budi, S. W., Qaim, M., Daniel, R., \& Polle, A. (2019). Intensive tropical land use massively shifts soil fungal communities. Scientific Reports, 9(1), 3403. doi: 10.1038/s41598-019-39829-4

Carrillo-Saucedo, S. M., Gavito, M. E., \& Siddique, I. (2018). Arbuscular mycorrhizal fungal spore communities of a tropical dry forest ecosystem show resilience to land-use change. Fungal Ecology, 32, 29-39. doi: 10.1016/j.funeco.2017.11.006

Chai, Y., Cao, Y., Yue, M., Tian, T., Yin, Q., Dang, H., Quan, J., Ruichang, Z., \& Wang, M. (2019). Soil abiotic properties and plant functional traits mediate associations between soil microbial and plant communities during a secondary forest succession on the Loess Plateau. Frontiers in Microbiology, 10. doi: 10.3389/fmicb.2019.00895

Chen, L., Reeve, J., Zhang, L., Huang, S., Wang, X., \& Chen, J. (2018). GMPR: A robust normalization method for zero-inflated count data with application to microbiome sequencing data. PeerJ, 6 . doi: 10.7717/peerj.4600

Dai, M., Bainard, L. D., Hamel, C., Gan, Y., \& Lynch, D. (2013). Impact of land use on arbuscular mycorrhizal fungal communities in rural Canada. Applied and Environmental Microbiology, 79(21), 6719-6729. doi: 10.1128/AEM.01333-13

Davison, J., Moora, M., Öpik, M., Adholeya, A., Ainsaar, L., Bâ, A., Burla, S., Diedhiou, A. G., Hiiesalu, I., Jairus, T., Johnson, N. C., Kane, A., Koorem, K., Kochar, M., Ndaiye, C., Pärtel, M., Reier, Ü., Saks, Ü., Singh, R., Vasar, M., \& Zobel, M. (2015). Global assessment of arbuscular mycorrhizal fungus diversity reveals very low endemism. Science, 349(6251), 970-973. doi: 10.1126/science.aab1161 
de Cáceres, M., \& Legendre, P. (2009). Associations between species and groups of sites: Indices and statistical inference. Ecology, 90(12), 3566-3574. doi: 10.1890/08-1823.1

de León, D. G., Davison, J., Moora, M., Öpik, M., Feng, H., Hiiesalu, I., Jairus, T., Koorem, K., Liu, Y., Phosri, C., Sepp, S.-K., Vasar, M., \& Zobel, M. (2018). Anthropogenic disturbance equalizes diversity levels in arbuscular mycorrhizal fungal communities. Global Change Biology, 24(6), 2649-2659. doi: 10.1111/gcb.14131

de León, D. G., Neuenkamp, L., Moora, M., Öpik, M., Davison, J., Peña-Venegas, C. P., Vasar, M., Jairus, T., \& Zobel, M. (2018). Arbuscular mycorrhizal fungal communities in tropical rain forest are resilient to slash-and-burn agriculture. Journal of Tropical Ecology, 34(3), 186-199. doi: 10.1017/S0266467418000184

de Pontes, J. S., Oehl, F., Pereira, C. D., de Toledo Machado, C. T., Coyne, D., da Silva, D. K. A., \& Maia, L. C. (2017). Diversity of arbuscular mycorrhizal fungi in the Brazilian's Cerrado and in soybean under conservation and conventional tillage. Applied Soil Ecology, 117-118, 178-189. doi: 10.1016/j.apsoil.2017.04.023

Dormann, C. F., Fründ, J., Blüthgen, N., \& Gruber, B. (2009). Indices, graphs and null models: Analyzing bipartite ecological networks. The Open Ecology Journal, 2(1),7-24. doi: 10.2174/1874213000902010007

Drescher, J., Rembold, K., Allen, K., Beckschäfer, P., Buchori, D., Clough, Y., Faust, H., Fauzi, A. M., Gunawan, D., \& Hertel, D. (2016). Ecological and socio-economic functions across tropical land use systems after rainforest conversion. Phil. Trans. R. Soc. B, 371(1694), 20150275.

Druille, M., Omacini, M., Golluscio, R. A., \& Cabello, M. N. (2013). Arbuscular mycorrhizal fungi are directly and indirectly affected by glyphosate application. Applied Soil Ecology, 72, 143-149. doi: 10.1016/j.apsoil.2013.06.011

Dufrene, M., \& Legendre, P. (1997). Species assemblages and indicator species: The need for a flexible asymmetrical approach. Ecological Monographs, 67(3), 345-366.

Edy, N. (2015). Community structure of arbuscular mycorrhizal fungi in temeprate grassland and tropical landuse systems. Georg-August Universität, Göttingen.

Egerton-Warburton, L. M., Querejeta, J. I., \& Allen, M. F. (2007). Common mycorrhizal networks provide a potential pathway for the transfer of hydraulically lifted water between plants. Journal of Experimental Botany, 58(6), 1473-1483. doi: 10.1093/jxb/erm009

Engelmoer, D. J. P., \& Kiers, E. T. (2015). Host diversity affects the abundance of the extraradical arbuscular mycorrhizal network. New Phytologist, 205(4), 1485-1491. doi: 10.1111/nph.13086

Epp Schmidt, D. J., Pouyat, R., Szlavecz, K., Setälä, H., Kotze, D. J., Yesilonis, I., Cilliers, S., Hornung, E., Dombos, M., \& Yarwood, S. A. (2017). Urbanization erodes ectomycorrhizal fungal diversity and may cause microbial communities to converge. Nature Ecology \& Evolution, 1(5), 0123. doi: 10.1038/s41559-0170123

Fox, J., \& Weisberg, S. (2019). An $\{R\}$ companion to applied regression (Third Edition). Thousand Oaks, USA: Sage.

Frąc, M., Hannula, S. E., Bełka, M., \& Jędryczka, M. (2018). Fungal biodiversity and their role in soil health. Frontiers in Microbiology, 9. doi: 10.3389/fmicb.2018.00707

Gerdemann, J. W., \& Nicolson, T. H. (1963). Spores of mycorrhizal Endogone species extracted from soil by wet sieving and decanting. Transactions of the British Mycological Society, 46(2), 235-244. doi: 10.1016/S0007-1536(63)80079-0

Gosling, P., Mead, A., Proctor, M., Hammond, J. P., \& Bending, G. D. (2013). Contrasting arbuscular mycorrhizal communities colonizing different host plants show a similar response to a soil phosphorus concentration gradient. The New Phytologist, 198(2), 546-556. doi: 10.1111/nph.12169

Gossner, M., Lewinsohn, T. M., Kahl, T., , Grassein, F., Boch, S., Prati, D., Birkhofer, K., Renner, S. C., Sikorski, J., Wubet T., Arndt, H., Baumgartner, V., Blaser, S., Blüthgen, N., Börschig, C., Buscot, F., Diekötter, T., Jorge, L. R., Jung, K., Keyel, A. C., Klein, A.-M., Klemmer, S., Krauss, J., Lange, M., Müller, J., Overmann, J., Pašalić, E., Penone, C., Perović, D. J., Purschke, O., Schall, P., Socher, S. A., Sonnemann, I., Tschapka, M., Tscharntke, T., Türke, M., Venter, P. C., Weiner, C. N., Werner, M., Wolters, V., Wurst, S., Westphal, C., Fischer, M., Weisser, W. W., \& Allan, E. (2016). Land-use intensification causes multitrophic homogenization of grassland communities. Nature, 540(7632), 266-269. doi: $10.1038 /$ nature20575 
Grass, I., Kubitza, C., Krishna, V. V., Corre, M. D., Mußhoff, O., Pütz, P., Drescher, J., Rembold, K., Ariyanti, E. S., Barnes, A. D., Brinkmann, N., Brose, U., Brümmer, B., Buchori, D., Daniel, R., Darras, K. F. A., Faust, H., Fehrmann, L., Hain, J., Hennings, N., Hidayat, P., Hölscher, D., Jochum, M., Knohl, A., Kotowska, M. M., Krashevska, V., Kreft, H., Leuschner, C., Lobite, N. J. S., Panjaitan, R., Polle, A., Potapov, A. M., Purnama, E., Qaim, M., Röll, A., Scheu, S., Schneider, D., Tjoa, A., Tscharntke, T., Veldkamp, E., \& Wollni, M. (2020). Trade-offs between multifunctionality and profit in tropical smallholder landscapes. Nature Communications, 11(1), 1-13. doi: 10.1038/s41467-020-15013-5

Guadarrama, P., \& Álvarez-Sánchez, F. J. (1999). Abundance of arbuscular mycorrhizal fungi spores in different environments in a tropical rain forest, Veracruz, Mexico. Mycorrhiza, 8(5), 267-270. doi: 10.1007/s005720050244

Hazard, C., Gosling, P., van der Gast, C. J., Mitchell, D. T., Doohan, F. M., \& Bending, G. D. (2013). The role of local environment and geographical distance in determining community composition of arbuscular mycorrhizal fungi at the landscape scale. The ISME Journal, 7(3), 498-508. doi: 10.1038/ismej.2012.127

Herzog, F., Steiner, B., Bailey, D., Baudry, J., Billeter, R., Bukácek, R., de Blust, G., de Cocok, R., Dirksen, J., Dormann, C. F., de Filippi, R., Frossard, E., Liira, j., Schmidt, T., Stöckli, R., Thenail, C., van Wingerden, W., \& Bugter, R. (2006). Assessing the intensity of temperate European agriculture at the landscape scale. European Journal of Agronomy, 24(2), 165-181. doi: 10.1016/j.eja.2005.07.006

Hodge, A., \& Storer, K. (2015). Arbuscular mycorrhiza and nitrogen: Implications for individual plants through to ecosystems. Plant and Soil, 386(1), 1-19. doi: 10.1007/s11104-014-2162-1

Hothorn, T., Bretz, F., \& Westfall, P. (2008). Simultaneous inference in general parametric models. Biometrical Journal. Biometrische Zeitschrift, 50(3), 346-363. doi: 10.1002/bimj.200810425

Johnson, N. C. (1993). Can fertilization of soil select less mutualistic mycorrhizae? Ecological Applications, 3(4), 749-757. doi: 10.2307/1942106

Jung, S. C., Martinez-Medina, A., Lopez-Raez, J. A., \& Pozo, M. J. (2012). Mycorrhiza-induced resistance and priming of plant defenses. Journal of Chemical Ecology, 38(6), 651-664. doi: 10.1007/s10886-0120134-6

Kerfahi, D., Tripathi, B. M., Dong, K., Go, R., \& Adams, J. M. (2016). Rainforest conversion to rubber plantation may not result in lower soil diversity of bacteria, fungi, and nematodes. Microbial Ecology, 72(2), 359371. doi: 10.1007/s00248-016-0790-0

Kivlin, S. N., Hawkes, C. V., \& Treseder, K. K. (2011). Global diversity and distribution of arbuscular mycorrhizal fungi. Soil Biology and Biochemistry, 43(11), 2294-2303. doi: 10.1016/j.soilbio.2011.07.012

Klironomos, J., Zobel, M., Tibbett, M., Stock, W. D., Rillig, M. C., Parrent, J. L., Moora, M., Koch, A. M., Facelli, E., Dickie, I. A., \& Bever, J. D. (2011). Forces that structure plant communities: Quantifying the importance of the mycorrhizal symbiosis. New Phytologist, 189(2), 366-370. doi: 10.1111/j.14698137.2010.03550.x

Leal, P. L., Siqueira, J. O., \& Stürmer, S. L. (2013). Switch of tropical Amazon forest to pasture affects taxonomic composition but not species abundance and diversity of arbuscular mycorrhizal fungal community. Applied Soil Ecology, 71, 72-80. doi: 10.1016/j.apsoil.2013.05.010

Lekberg, Y., Vasar, M., Bullington, L. S., Sepp, S.-K., Antunes, P. M., Bunn, R., Larkin, B. G., \& Öpik, M. (2018). More bang for the buck? Can arbuscular mycorrhizal fungal communities be characterized adequately alongside other fungi using general fungal primers? New Phytologist, 220(4), 971-976. doi: 10.1111/nph.15035

Li, L.-F., Zhang, Y., \& Zhao, Z.-W. (2007). Arbuscular mycorrhizal colonization and spore density across different land-use types in a hot and arid ecosystem, Southwest China. Journal of Plant Nutrition and Soil Science, 170(3), 419-425. doi: 10.1002/jpln.200625034

Lindahl, B. D., Nilsson, R. H., Tedersoo, L., Abarenkov, K., Carlsen, T., Kjøller, R., Kõljalg, U., Pennanen, T., Rosendahl, S., Stenlid, J., \& Kauserud, H. (2013). Fungal community analysis by high-throughput sequencing of amplified markers-A user's guide. New Phytologist, 199(1), 288-299. doi: 10.1111/nph.12243

Louis, I., \& Lim, G. (1987). Spore density and root colonization of vesicular-arbuscular mycorrhizas in tropical soil. Transactions of the British Mycological Society, 88(2), 207-212. doi: 10.1016/S00071536(87)80216-4 
Lumini, E., Orgiazzi, A., Borriello, R., Bonfante, P., \& Bianciotto, V. (2010). Disclosing arbuscular mycorrhizal fungal biodiversity in soil through a land-use gradient using a pyrosequencing approach. Environmental Microbiology, 12(8), 2165-2179. doi: 10.1111/j.1462-2920.2009.02099.x

Margono, B. A., Potapov, P. V., Turubanova, S., Stolle, F., \& Hansen, M. C. (2014). Primary forest cover loss in Indonesia over 2000-2012. Nature Climate Change, 4(8), 730-735. doi: 10.1038/nclimate2277

McGonigle, T. P., Miller, M. H., Evans, D. G., Fairchild, G. L., \& Swan, J. A. (1990). A new method which gives an objective measure of colonization of roots by vesicular-Arbuscular mycorrhizal fungi. New Phytologist, 115(3), 495-501. doi: 10.1111/j.1469-8137.1990.tb00476.x

McGuire, K. L., D’Angelo, H., Brearley, F. Q., Gedallovich, S. M., Babar, N., Yang, N., Gillikin, C. M.,Gradoville, R., Bateman, C., Turner, B. L., Mansor, P., Leff, J. W., \& Fierer, N. (2015). Responses of soil fungi to logging and oil palm agriculture in Southeast Asian tropical forests. Microbial Ecology, 69(4), 733-747. doi: 10.1007/s00248-014-0468-4

Moora, M., Davison, J., Öpik, M., Metsis, M., Saks, Ü., Jairus, T., Vasar, M., Zobel, M. (2014). Anthropogenic land use shapes the composition and phylogenetic structure of soil arbuscular mycorrhizal fungal communities. FEMS Microbiology Ecology, 90(3), 609-621. doi: 10.1111/1574-6941.12420

Mueller, R. C., Rodrigues, J. L. M., Nüsslein, K., \& Bohannan, B. J. M. (2016). Land use change in the Amazon rain forest favours generalist fungi. Functional Ecology, 30(11), 1845-1853. doi: 10.1111/1365-2435.12651

Newbold, T., Hudson, L. N., Hill, S. L. L., Contu, S., , Lysenko, I., Senior, R. A., Börger, L., Bennett, D. J., Choimes, A., Collen B., Day, J., de Palma, A., Díaz, S., Echeverria-Londoño, S., Edgar, M. J., Feldman, A., Garon, M., Harrison M. L. K., Alhusseini, T., Ingram, D. J., Itescu, Y., Kattge, J., Kemp, V., Kirkpatrick, L., Kleyer, M., Correia, D. L. P., Martin, C. D., Meiri, S., Novosolov, M., Pan, Y., Phillips, H. R. P., Purves, D. W., Robinson, A., Simpson, J., Tuck, S. L., Weiher, E., White, H. J., Ewers, R. M., Mace, G. M., Scharlemann, J. P. W., \& Purvis, A. (2015). Global effects of land use on local terrestrial biodiversity. Nature, 520(7545), 45-50. doi: 10.1038/nature14324

Oehl, F., Laczko, E., Bogenrieder, A., Stahr, K., Bösch, R., van der Heijden, M., \& Sieverding, E. (2010). Soil type and land use intensity determine the composition of arbuscular mycorrhizal fungal communities. Soil Biology and Biochemistry, 42(5), 724-738. doi: 10.1016/j.soilbio.2010.01.006

Oehl, F., Laczko, E., Oberholzer, H.-R., Jansa, J., \& Egli, S. (2017). Diversity and biogeography of arbuscular mycorrhizal fungi in agricultural soils. Biology and Fertility of Soils, 53(7), 777-797. doi: 10.1007/s00374-017-1217-x

Oehl, F., Sieverding, E., Ineichen, K., Mäder, P., Boller, T., \& Wiemken, A. (2003). Impact of land use intensity on the species diversity of arbuscular mycorrhizal fungi in agroecosystems of central europe. Applied and Environmental Microbiology, 69(5), 2816-2824. doi: 10.1128/AEM.69.5.2816-2824.2003

Oksanen, J., Blanchet, F. G., Friendly, M., Kindt, R., Legendre, P., McGlinn, D., Minchin, P. R., O’Hara, R. B., Simpson, G. L., Solymos, P., Stevens, M. H. H., Szoecs, E., \& Wagner, H. (2019). vegan: Community Ecology Package version 2.5-6.

Öpik, M., Vanatoa, A., Vanatoa, E., Moora, M., Davison, J., Kalwij, J. M., Reier, Ü., Zobel, M. (2010). The online database MaarjAM reveals global and ecosystemic distribution patterns in arbuscular mycorrhizal fungi (Glomeromycota). New Phytologist, 188(1), 223-241. doi: 10.1111/j.1469-8137.2010.03334.x

Öpik, Maarja, Davison, J., Moora, M., \& Zobel, M. (2013). DNA-based detection and identification of Glomeromycota: The virtual taxonomy of environmental sequences. Botany, 92(2), 135-147. doi: 10.1139/cjb-2013-0110

Peay, K. G., Kennedy, P. G., \& Bruns, T. D. (2008). Fungal community ecology: A hybrid beast with a molecular master. AIBS Bulletin, 58(9), 799-810.

Peña, E. D. L., Echeverría, S. R., Putten, W. H. V. D., Freitas, H., \& Moens, M. (2006). Mechanism of control of root-feeding nematodes by mycorrhizal fungi in the dune grass Ammophila arenaria. New Phytologist, 169(4), 829-840. doi: 10.1111/j.1469-8137.2005.01602.x

R Core Team. (2019). R: A language and environment for statistical computing. R Foundation for Statistical Computing, Vienna, Austria.

Rembold, K., Mangopo, H., Tjitrosoedirdjo, S. S., \& Kreft, H. (2017). Plant diversity, forest dependency, and alien plant invasions in tropical agricultural landscapes. Biological Conservation, 213, 234-242. doi: 10.1016/j.biocon.2017.07.020 
Rodrigues, J. L. M., Pellizari, V. H., Mueller, R., Baek, K., Jesus, E. D. C., Paula, F. S., Mirza, B., Hamaoui, G. S., Tsai, S. M, Feigl, B., Tiedje, J. M., Bohannan, B. J. M. \& Nusslein, K. (2013). Conversion of the Amazon rainforest to agriculture results in biotic homogenization of soil bacterial communities. Proceedings of the National Academy of Sciences, 110(3), 988-993. doi: 10.1073/pnas.1220608110

Rodríguez-Echeverría, S., Teixeira, H., Correia, M., Timóteo, S., Heleno, R., Öpik, M., \& Moora, M. (2017). Arbuscular mycorrhizal fungi communities from tropical Africa reveal strong ecological structure. New Phytologist, 213(1), 380-390. doi: 10.1111/nph.14122

Sahner, J. (2016). Impact of rain forest transformation on roots and functional diversity of root - associated fungal communities. Georg-August Universität, Göttingen.

Sahner, J., Budi, S. W., Barus, H., Edy, N., Meyer, M., Corre, M. D., \& Polle, A. (2015). Degradation of root community traits as indicator for transformation of tropical lowland rain forests into oil palm and rubber plantations. PLOS ONE, 10(9), e0138077. doi: 10.1371/journal.pone.0138077

Schoch, C. L., Seifert, K. A., Huhndorf, S., Robert, V., Spouge, J. L., Levesque, C. A., Chen, W., \& Fungal Barcoding Consortium (2012). Nuclear ribosomal internal transcribed spacer (ITS) region as a universal DNA barcode marker for fungi. Proceedings of the National Academy of Sciences of the United States of America, 109(16), 6241-6246. doi: 10.1073/pnas.1117018109

Sepp, S.-K., Jairus, T., Vasar, M., Zobel, M., \& Öpik, M. (2018). Effects of land use on arbuscular mycorrhizal fungal communities in Estonia. Mycorrhiza, 28(3), 259-268. doi: 10.1007/s00572-018-0822-3

Sheldrake, M., Rosenstock, N. P., Mangan, S., Revillini, D., Sayer, E. J., Olsson, P. A., Verbruggen, E., Tanner, E.V. J., Turner, B. L., \& Wright, S. J. (2018). Responses of arbuscular mycorrhizal fungi to long-term inorganic and organic nutrient addition in a lowland tropical forest. The ISME Journal, 12(10), 24332445. doi: 10.1038/s41396-018-0189-7

Smith, S. E., \& Read, D. (2008). Mycorrhizal symbiosis. doi: 10.1016/B978-0-12-370526-6.X5001-6

Soka, G. E., \& Ritchie, M. E. (2018). Arbuscular mycorrhizal spore composition and diversity associated with different land uses in a tropical savanna landscape, Tanzania. Applied Soil Ecology, 125, 222-232. doi: 10.1016/j.apsoil.2018.01.013

Sonnemann, I., Buchholz, Y., Rautenberg, D., \& Wurst, S. (2016). Land use intensity modulates the impact of root herbivores on plant interactions with above- and below-ground organisms. Agriculture, Ecosystems \& Environment, 219, 26-31. doi: 10.1016/j.agee.2015.12.003

Steidinger, B. S., Crowther, T. W., Liang, J., Nuland, M. E. V., Werner, G. D. A., Reich, P. B., Nabuurs, G. J., de Miguel, S., Zhou, M., Picard, N., Herault, B., Zhao, X., Zhang, C., Routh, D., \& Peay, K. G. (2019). Climatic controls of decomposition drive the global biogeography of forest-tree symbioses. Nature, 569(7756), 404-408. doi: 10.1038/s41586-019-1128-0

Stevens, B. M., Propster, J. R., Öpik, M., Wilson, G. W. T., Alloway, S. L., Mayemba, E., \& Johnson, N. C. (2020). Arbuscular mycorrhizal fungi in roots and soil respond differently to biotic and abiotic factors in the Serengeti. Mycorrhiza. doi: 10.1007/s00572-020-00931-5

Stürmer, S. L., \& Siqueira, J. O. (2011). Species richness and spore abundance of arbuscular mycorrhizal fungi across distinct land uses in Western Brazilian Amazon. Mycorrhiza, 21(4), 255-267. doi: 10.1007/s00572-010-0330-6

Tchabi, A., Coyne, D., Hountondji, F., Lawouin, L., Wiemken, A., \& Oehl, F. (2008). Arbuscular mycorrhizal fungal communities in sub-Saharan Savannas of Benin, West Africa, as affected by agricultural land use intensity and ecological zone. Mycorrhiza, 18(4), 181-195. doi: 10.1007/s00572-008-0171-8

Toju, H., Tanabe, A. S., Yamamoto, S., \& Sato, H. (2012). High-coverage ITS primers for the DNA-based identification of Ascomycetes and Basidiomycetes in environmental samples. PLoS ONE, 7(7), e40863. doi: 10.1371/journal.pone.0040863

Treseder, K. K. (2004). A meta-analysis of mycorrhizal responses to nitrogen, phosphorus, and atmospheric $\mathrm{CO} 2$ in field studies. New Phytologist, 164(2), 347-355. doi: 10.1111/j.1469-8137.2004.01159.x

Treseder, K. K. (2016). Model behavior of arbuscular mycorrhizal fungi: Predicting soil carbon dynamics under climate change. Botany, 94(6), 417-423. doi: 10.1139/cjb-2015-0245

Vályi, K., Rillig, M. C., \& Hempel, S. (2015). Land-use intensity and host plant identity interactively shape communities of arbuscular mycorrhizal fungi in roots of grassland plants. New Phytologist, 205(4), 1577-1586. doi: 10.1111/nph.13236 
van der Heijden, M. G. A, Martin, F. M., Selosse, M.-A., \& Sanders, I. R. (2015). Mycorrhizal ecology and evolution: The past, the present, and the future. New Phytologist, 205(4), 1406-1423. doi: 10.1111/nph.13288

Venables, W. N., \& Ripley, B. D. (2002). Modern applied statistics with S (4th Edition). doi: 10.1007/978-0-38721706-2

Verbruggen, E., van der Heijden, M. G. A., Weedon, J. T., Kowalchuk, G. A., \& Röling, W. F. M. (2012). Community assembly, species richness and nestedness of arbuscular mycorrhizal fungi in agricultural soils. Molecular Ecology, 21(10), 2341-2353. doi: 10.1111/j.1365-294X.2012.05534.x

Vierheilig, H., Coughlan, A. P., Wyss, U., \& Piché, Y. (1998). Ink and Vinegar, a simple staining technique for arbuscular-mycorrhizal fungi. Applied and Environmental Microbiology, 64(12), 5004-5007.

Vijay, V., Pimm, S. L., Jenkins, C. N., \& Smith, S. J. (2016). The impacts of oil palm on recent deforestation and biodiversity loss. PLOS ONE, 11(7). doi: 10.1371/journal.pone.0159668

White, T. J., Bruns, T., Lee, S., \& Taylor, J. (1990). Amplification and direct sequencing of fungal ribosomal RNA genes for phylogenetics. In M. A. Innis, D. H. Gelfand, J. J. Sninsky, \& T. J. White (Eds.), PCR protocols: A guide to methods and applications (pp. 315-322). Cambridge, USA: Academic Press

Wilson, G. W. T., Rice, C. W., Rillig, M. C., Springer, A., \& Hartnett, D. C. (2009). Soil aggregation and carbon sequestration are tightly correlated with the abundance of arbuscular mycorrhizal fungi: Results from long-term field experiments. Ecology Letters, 12(5), 452-461. doi: 10.1111/j.1461-0248.2009.01303.x

Wyatt, T. T., Wösten, H. A. B., \& Dijksterhuis, J. (2013). Fungal spores for dispersion in space and time. In S. Sariaslani \& G. M. Gadd (Eds.), Advances in applied microbiology (pp. 43-91). Cambridge, USA: Academic Press

Xiang, D., Verbruggen, E., Hu, Y., Veresoglou, S. D., Rillig, M. C., Zhou, W., Xu, T., Li, H., Hao, Z., Chen, Y., \& Chen, B. (2014). Land use influences arbuscular mycorrhizal fungal communities in the farming-pastoral ecotone of northern China. New Phytologist, 204(4), 968-978. doi: 10.1111/nph.12961

Zhang, T., Yang, X., Guo, R., \& Guo, J. (2016). Response of AM fungi spore population to elevated temperature and nitrogen addition and their influence on the plant community composition and productivity. Scientific Reports, 6(1), 1-12. doi: 10.1038/srep24749

Zobel, M., \& Öpik, M. (2014). Plant and arbuscular mycorrhizal fungal (AMF) communities - which drives which? Journal of Vegetation Science, 25(5), 1133-1140. doi: 10.1111/jvs.12191 


\section{Declaration of other contributions}

Dr. Josephine Sahner (Forest Botany and Tree Physiology, University of Goettingen) provided data for the sampling campaign 2013; Dr. Dominik Schneider (Genomic and Applied Microbiology and Göttingen Genomics Laboratory, University of Goettingen) performed the bioinformatic processing of the raw sequences; Aisjah Ryadin (Forest Botany and Tree Physiology, University of Goettingen) performed the staining of mycorrhiza in plant roots 2016, Dr. Sri Wilarso Budi (Department of Sylviculture, IPB Bogor) conducted the AM spore counts; management and yield data were provided by the Central Scientific Service Group (Z02) of the EFForTS (CRC 990, University of Goettingen). 


\section{Supplementary Information}

Supplementary Table S 2.1.1 Components used to estimate the land-use intensity in each plot for the years $2013-2016$. $Y=$ yield $\left[\mathrm{kg} \mathrm{ha}^{-1} \mathrm{y}^{-1}\right], \mathrm{W}=$ weeding events, $F=$ fertilizer components $\left[\mathrm{kg} \mathrm{ha}^{-1}\right.$ $\left.\mathbf{y}^{-1}\right], \mathbf{H}=$ herbicide application weighted by applied concentration, $\mathbf{S}=$ plant species richness. Detailed information on the applied chemicals is given in Table 2.1.1.

See digital supplement supp/Table_S211.xIxs 
Supplementary Table S 2.1.2 Land-use intensity (LUI) and richness (OTUs), abundance (reads), spore abundance and root colonization (\%) of arbuscular mycorrhizal fungi (AM) in all plots

\begin{tabular}{|c|c|c|c|c|c|c|c|c|c|c|c|c|c|c|}
\hline \multirow[b]{2}{*}{ ID } & \multicolumn{4}{|c|}{ LUI } & \multicolumn{2}{|c|}{$\begin{array}{c}\text { Mean } \\
\text { LUI }\end{array}$} & \multicolumn{2}{|c|}{ AM richness } & \multicolumn{2}{|c|}{$\begin{array}{c}\text { AM } \\
\text { abundance }\end{array}$} & \multicolumn{2}{|c|}{$\begin{array}{c}\text { AM } \\
\text { spores }\end{array}$} & \multicolumn{2}{|c|}{ AM colon. } \\
\hline & 2013 & 2014 & 2015 & 2016 & $13-14$ & $15-16$ & 13 & 16 & 13 & 16 & 13 & 16 & 13 & 16 \\
\hline BF1 & 0.067 & 0.067 & 0.067 & 0.067 & 0.067 & 0.067 & 63 & 77 & 1562 & 5371 & 3 & 137 & 83 & 65 \\
\hline BF2 & 0.000 & 0.000 & 0.000 & 0.000 & 0.000 & 0.000 & 44 & 27 & 575 & 643 & 8 & 216 & 88 & 59 \\
\hline BF3 & 0.431 & 0.431 & 0.431 & 0.431 & 0.431 & 0.431 & 32 & 37 & 607 & 1911 & 6 & 264 & 73 & 54 \\
\hline BF4 & 0.360 & 0.360 & 0.360 & 0.360 & 0.360 & 0.360 & 45 & 30 & 502 & 1373 & NA & 329 & NA & 53 \\
\hline BJ3 & 0.449 & 0.611 & 0.878 & 0.846 & 0.530 & 0.862 & 26 & 79 & 359 & 13070 & 37 & 374 & 78 & NA \\
\hline BJ4 & 0.335 & 0.304 & 0.297 & 0.285 & 0.319 & 0.291 & 36 & 87 & 579 & 6632 & 33 & 88 & 58 & 69 \\
\hline BJ5 & NA & NA & 0.562 & 0.460 & NA & 0.511 & NA & 69 & NA & 13224 & NA & 361 & NA & 80 \\
\hline BJ6 & NA & NA & 0.419 & 0.419 & NA & 0.419 & NA & 73 & NA & 9948 & NA & 294 & NA & 71 \\
\hline BO2 & 1.245 & 1.315 & 1.781 & 2.733 & 1.280 & 2.257 & 1 & 30 & 6 & 847 & 85 & 493 & 71 & 43 \\
\hline BO3 & 1.892 & 2.541 & 3.105 & 2.268 & 2.216 & 2.686 & 3 & 38 & 36 & 1424 & 108 & 627 & 87 & 37 \\
\hline BO4 & 1.575 & 1.986 & 1.506 & 2.036 & 1.781 & 1.771 & 19 & 43 & 378 & 1221 & 97 & 479 & 71 & 37 \\
\hline BO5 & NA & NA & 3.031 & 2.655 & NA & 2.843 & NA & 21 & NA & 682 & NA & 379 & NA & 59 \\
\hline BR1 & 2.879 & 1.723 & 1.787 & 0.996 & 2.301 & 1.391 & 21 & 37 & 716 & 5283 & 96 & 181 & 86 & 53 \\
\hline BR2 & 2.835 & 1.835 & 1.796 & 1.835 & 2.335 & 1.816 & 27 & 68 & 415 & 4874 & 81 & 337 & 87 & 62 \\
\hline BR3 & 2.191 & 2.334 & 2.156 & 1.726 & 2.262 & 1.941 & 13 & 45 & 477 & 3723 & 102 & 823 & 77 & 56 \\
\hline BR4 & 0.949 & 1.084 & 1.429 & 1.564 & 1.017 & 1.496 & 8 & 58 & 132 & 3377 & 105 & 326 & 71 & 71 \\
\hline HF1 & 0.010 & 0.010 & 0.010 & 0.010 & 0.010 & 0.010 & 49 & 88 & 734 & 13568 & 34 & 366 & 74 & 65 \\
\hline HF2 & 0.058 & 0.058 & 0.058 & 0.058 & 0.058 & 0.058 & 24 & 81 & 642 & 13585 & 34 & 132 & 70 & 64 \\
\hline HF3 & 0.000 & 0.000 & 0.000 & 0.000 & 0.000 & 0.000 & 15 & 62 & 928 & 10299 & 32 & 258 & 87 & 58 \\
\hline HF4 & 0.144 & 0.144 & 0.144 & 0.144 & 0.144 & 0.144 & 32 & 60 & 1401 & 4488 & 24 & 266 & 78 & 63 \\
\hline HJ1 & 1.059 & 0.998 & 0.939 & 0.888 & 1.028 & 0.913 & 16 & 68 & 344 & 6804 & 50 & 518 & 93 & 61 \\
\hline $\mathrm{HJ} 2$ & 1.998 & 0.925 & 0.790 & 0.603 & 1.462 & 0.696 & 37 & 61 & 578 & 4498 & NA & 274 & NA & 62 \\
\hline HJ3 & 0.945 & 0.938 & 0.807 & 0.568 & 0.942 & 0.688 & 40 & 70 & 735 & 6471 & 42 & 231 & 67 & 57 \\
\hline HJ4 & 1.644 & 0.705 & 0.414 & 0.414 & 1.174 & 0.414 & 0 & 74 & 0 & 8725 & 39 & 233 & 69 & 54 \\
\hline HO1 & 3.671 & 3.613 & 1.685 & 1.993 & 3.642 & 1.839 & 4 & 43 & 90 & 3024 & 72 & 835 & 58 & 39 \\
\hline $\mathrm{HO} 2$ & 3.639 & 2.276 & 1.700 & 1.795 & 2.957 & 1.747 & 11 & 47 & 178 & 2073 & 77 & 390 & 58 & 34 \\
\hline HO3 & 3.894 & 3.318 & 1.769 & 1.818 & 3.606 & 1.794 & 20 & 67 & 430 & 2881 & 68 & 558 & 40 & 33 \\
\hline HO4 & 3.216 & 1.482 & 1.674 & 1.637 & 2.349 & 1.656 & 32 & 45 & 517 & 1655 & 60 & 1220 & 51 & 44 \\
\hline HR1 & 2.513 & 1.245 & 1.263 & 1.275 & 1.879 & 1.269 & 15 & 61 & 130 & 2517 & 73 & 447 & 90 & 72 \\
\hline HR2 & 3.053 & 2.585 & 1.499 & 2.414 & 2.819 & 1.956 & 7 & 71 & 217 & 8225 & 43 & 351 & 80 & 69 \\
\hline HR3 & 2.360 & 1.860 & 1.860 & 1.860 & 2.110 & 1.860 & 11 & 72 & 382 & 5696 & 60 & 408 & 72 & NA \\
\hline HR4 & 0.977 & 0.951 & 1.192 & 1.034 & 0.964 & 1.113 & 8 & 101 & 292 & 11265 & 56 & 139 & 75 & NA \\
\hline
\end{tabular}

$\mathrm{B}=$ bukit, $\mathrm{H}=$ harapan, $\mathrm{F}=$ forest, $\mathrm{J}=$ jungle rubber, $\mathrm{R}=$ rubber, $\mathrm{O}=$ oil palm 
Supplementary Table S 2.1.3 Normalized read counts of fungal operational taxonomic units (OTU; clustered at $97 \%$ similarity threshold) for all plots in sampling years 2013 and 2016 (coluns 1 - 62) as well as their taxonomic affiliation (columns $63-70$ ); P1 = sampling year 2013; P2 = sampling year 2016; $H$ = harapan landscape; $B=$ bukit landscape; $F=$ forest; $J=$ jungle rubber; $R=$ rubber plantation; $\mathbf{O}=$ oil palm plantation

See digital supplement supp/Table_S213.xIxs

Supplementary Table S 2.1.4 Normalized read counts of arbuscular mycorrhizal fungi (Glomeromycota) operational taxonomic units (OTU; clustered at $97 \%$ similarity threshold) for all plots in sampling years 2013 and 2016); P1 = sampling year 2013; P2 = sampling year 2016; H = harapan landscape; $B=$ bukit landscape; $F=$ forest; $\mathrm{J}=$ jungle rubber; $\mathrm{R}=$ rubber plantation; $\mathrm{O}=$ oil palm plantation

See digital supplement supp/Table_S214.xIxs

Supplementary Table S 2.1.5 Rarefied read counts of fungal operational taxonomic units (OTU; clustered at $97 \%$ similarity threshold) for all plots in sampling years 2013 and 2016); P1 = sampling year 2013; P2 = sampling year 2016; $H$ = harapan landscape; $B=$ bukit landscape; $F=$ forest; $J=$ jungle rubber; $\mathbf{R}=$ rubber plantation; $\mathbf{O}=$ oil palm plantation

See digital supplement supp/Table_S215.xlxs 


\subsection{Bottom-up effects of roots on belowground fungal communities in tropical land-use systems}

\section{Introduction}

Fungi have successfully colonized all terrestrial ecosystems (Frąc, Hannula, Bełka, \& Jędryczka, 2018; Tedersoo et al., 2014). In soil, fungi are key actors in biogeochemical cycles (Johnson, Angelard, Sanders, \& Kiers, 2013; Rillig, 2004), contributing to ecosystem processes, such as litter decomposition, carbon sequestration, nutrient mobilization, and nutrient transformation (Prescott \& Grayston, 2013; Six, Frey, Thiet, \& Batten, 2006; Treseder \& Lennon, 2015). According to their lifestyle, fungi have been grouped into three broad trophic categories: saprotrophs, symbiotrophs, and pathotrophs (Nguyen et al., 2016), each of which fulfills different ecological functions. While the majority of saprotrophic fungi are free-living, thriving on dead plant material, symbionts associate with living host roots, regulating nutrient exchange between above- and belowground, and plant pathogens colonize their host, thus structuring plant communities by negatively affecting on plant health (Clemmensen et al., 2013; García-Guzmán \& Heil, 2014; van der Heijden, Martin, Selosse, \& Sanders, 2015). Consequently, soil and roots are divergent habitats of belowground fungi, with distinct colonization patterns for different fungal lifestyles (Philippot, Raaijmakers, Lemanceau, \& van der Putten, 2013; van der Heijden, Dombrowski, \& Schlaeppi, 2017). Since small changes in fungal community structures can lead to big consequences for ecosystem matter fluxes (Orwin, Kirschbaum, John, \& Dickie, 2011), it is important to understand the factors that drive the turnover of fungal assemblages.

The assembly mechanisms of soil fungal communities (SFCs) have often been studied to gain insight into niche-neutral processes, such as dispersal limitation, stochastic events (Adams, Miletto, Taylor, \& Bruns, 2013; Barnes, Maldonado, Frøslev, Antonelli, \& Rønsted, 2016; Powell et al., 2015), and environmental filtering (Bahram et al., 2018; Tedersoo et al., 2014). Inconsistent results have been obtained for the influence of vegetation structure on soil microbes (Barberán et al., 2015; Leff et al., 2018; Rodríguez-Echeverría et al., 2017; Yang et al., 2019). In contrast to SFCs, less is known concerning the drivers of root-associated fungal communities (RFCs), and whether root properties have feedback effects on SFCs is unclear. This knowledge gap is particularly evident in the tropics, where massive land transformation has led to drastic losses in vegetation diversity and impacted root community traits (Rembold, Mangopo, Tjitrosoedirdjo, \& Kreft, 2017; Sahner et al., 2015).

Tropical lowland rainforests are among the most diverse ecosystems in the world (Gaston, 2000; Myers, Mittermeier, Mittermeier, Da Fonseca, \& Kent, 2000), but large areas have been lost because 
of conversion into farmland or plantations. In Indonesia, a hotspot of biodiversity and land conversion (Margono, Potapov, Turubanova, Stolle, \& Hansen, 2014), lowland rainforests were initially used as agroforestry systems, where rubber trees were planted into rainforests ("jungle rubber") and then converted into rubber (Hevea brasiliensis) plantations. Since the 2000s, rainforests have mainly been transformed into oil palm (Elaeis guineensis) plantations (Miettinen, Shi, \& Liew, 2011; Wilcove \& Koh, 2010). Vegetation in oil palm and rubber plantations is controlled by chemical or mechanical weeding, thereby, further reducing plant diversity. Despite the massive loss in plant diversity for plantations compared to rainforests (Grass et al., 2020; Koh, Levang, \& Ghazoul, 2009; Rembold et al., 2017; Stibig, Achard, Carboni, Raši, \& Miettinen, 2014), the richness of soil microbiota is not strongly affected, while a drastic turnover of these communities can be found (Brinkmann et al., 2019; Schneider et al., 2015). A strong turnover of fungal communities has also been reported for other tropical land transformation systems (Kerfahi, Tripathi, Dong, Go, \& Adams, 2016; Kerfahi, Tripathi, Lee, Edwards, \& Adams, 2014; McGuire et al., 2015; Mueller et al., 2014; Mueller, Rodrigues, Nüsslein, \& Bohannan, 2016). On the one hand, plants selectively recruit microorganisms from the soil biome (Broeckling, Broz, Bergelson, Manter, \& Vivanco, 2008; Danielsen et al., 2012; Goldmann et al., 2016; Moll et al., 2016; Urbina et al., 2018), while on the other hand, vegetation, especially dominant tree species, influence the soil microbiome (Berkelmann, Schneider, Meryandini, \& Daniel, 2020; Gao et al., 2017; Peay, Baraloto, \& Fine, 2013; Yang et al., 2019).Therefore, variation in host properties may be expected to influence both RFCs and SFCs in land transformation systems. However, holistic approaches that dissect environmental and plant impacts on different fungal guilds in soils and roots are currently lacking.

The primary aim of this study was to investigate spatial distance, soil chemistry, and root traits as drivers of symbiotrophic, saprotrophic, and pathotrophic fungi in soils and roots. For this investigation, we used well-established plots from a large-scale research program (CRC990, EFForTs) in the humid tropical lowlands on Sumatra (Indonesia) (Drescher et al., 2016). The plots were in four different land-use systems (forest, jungle rubber, rubber plantation, and oil plantation) and replicated in areas with different soil types (acrisol on loam and acrisol on clay; Allen, Corre, Tjoa, \& Veldkamp, 2015) and in riparian areas, where annual flooding leads to strongly altered soil redox potentials (Paoletti et al., 2018). We tested the following hypotheses: (i) The RFC is dependent upon plant root traits and, therefore, responds to changes in root properties more strongly than to changes in soil properties. (ii) The SFC provides the pool from which the RFC is recruited, and the pool of soil fungi is mainly determined by changes in soil properties and stochastic fluctuations. (iii) Assembly processes of all fungal groups are driven by soil chemistry, while the community structures of saprotrophs, mycorrhizal fungi, and plant pathogens on roots underlie additional divergent controls by root traits. 


\section{Materials and Methods}

\section{Study area}

The study was conducted in the Jambi Province (Sumatra, Indonesia). The region has a humid tropical climate (mean annual temperature and precipitation of $26.7^{\circ} \mathrm{C}$ and $2235 \mathrm{~mm}$, respectively), with a dry season from July to August and a wet season with two rainfall peaks around March and December (Drescher et al., 2016). Beginning in the 1970's, naturally occurring dipterocarpdominated rainforests in the lowlands where severely logged and transformed into agricultural farmland (Rembold et al., 2017), with a strong focus on plantation crops of high economic value, such as rubber (Hevea brasiliensis) and oil palm (Elaeis guineensis) (Drescher et al., 2016).

Since 2012 , a total of 44 research plots $(50 \times 50 \mathrm{~m})$ have been installed as part of a long-term project: "Ecological and Socioeconomic Functions of Tropical Lowland Rainforest Transformation Systems (Sumatra, Indonesia)" (CRC 990, EFForts, https://www.uni-goettingen.de/en/310995.html). The plots encompass four different land-use systems: "Forest (F)": lowland rainforests with little selective logging in the past, located in the National reservations PT Restorasi Ekosistem Indonesia Forest Restoration project (Muaro Jambi Regency) and National Park Bukit Duabelas (Sarolangun Regency); "Jungle Rubber (J)": extensively managed rubber, planted in disturbed secondary forest; "Rubber $(\mathrm{R})$ ": monocultures of Hevea brasiliensis; and "Oil Palm (O)": monocultures of Elaeis guineensis. Oil palm plantations are intensively managed by the application of fertilizer (approximately 48 to $88 \mathrm{~kg}$ $\mathrm{N}, 21$ to $38 \mathrm{~kg} \mathrm{P}$, and 40 to $157 \mathrm{~kg} \mathrm{~K} \mathrm{ha}^{-1} \mathrm{yr}^{-1}$ ), while rubber plantations are usually not fertilized. Both oil palm and rubber plantations are weeded, manually or by the application of herbicides (Kurniawan et al., 2018).

Four plots of each land-use system were established in two landscapes, which are mainly distinguished by soil types. The landscape "Bukit (B)" is located approximately $110 \mathrm{~km}$ west of Jambi City (Sarolangun Regency) and dominated by clay Acrisols (Allen et al., 2015). The landscape "Harapan (H)" is located $60 \mathrm{~km}$ south of Jambi City (Muaro Jambi Regency). The Haparan landscape is characterized by loam Acrisol soils, which contain higher fractions of sand and silt and have a lower base saturation, soil organic carbon content, total soil nitrogen, and stocks of exchangeable base ( $\mathrm{Ca}$, $\mathrm{Mg}, \mathrm{K}$, and $\mathrm{N}$ ) and acid (Al, Fe, and Mn) cations compared to Bukit (Allen et al., 2015). In addition, we included riparian sites in the Harapan landscape with the land-use systems $F, R$, and $O$. Riparian sites are a link between aquatic and terrestrial ecosystems, with heavily altered habitat conditions compared to upland sites (Gregory, Swanson, McKee, \& Cummins, 1991). They represent one of the broad vegetation zones within tropical forests. The riparian plots were located close to rivers or streams and repeatedly flooded during the rainy season. In contrast to the well-drained Harapan plots, they display a stagnic color pattern to a depth of $0.3 \mathrm{~m}$ from the surface, which indicates 
longer periods of stagnating water causing alternated redox potentials (Paoletti et al., 2018). The geographic coordinates of the plots (Supplementary Table S 2.2.1) were used to calculate a pairwise spatial distance matrix between all plots.

\section{Sampling}

Sampling took place in October and November 2016. In each plot, three $5 \times 5 \mathrm{~m}$ subplots were installed at a distance of $15 \mathrm{~m}$ apart. Surface leaf litter was removed before soil collection. In each subplot, five soil cores (15 cm depth, $4 \mathrm{~cm}$ diameter) were extracted evenly across the area. These five soil cores were pooled, resulting in a total of three samples per plot. Samples were stored in ziplock bags at $4{ }^{\circ} \mathrm{C}$ until further processing. The soil was sieved through a $50 \times 50 \mathrm{~mm}$ mesh, and roots were separated from the soil. Roots were washed, separated into coarse and fine roots, and weighed. Aliquots of fine roots and soil samples were immediately freeze-dried (VirTis Bench Top K, SP Industries, Warminster, USA) and exported to the University of Göttingen (Germany) for molecular analysis. Further aliquots of soil and roots were dried at $60{ }^{\circ} \mathrm{C}$ for two days. Root biomass was calculated as:

$$
\text { Root biomass }\left[\mathrm{g} \mathrm{m}^{-2}\right]=\text { Fresh biomass }[\mathrm{g}] * \frac{\text { Dry biomass aliquot }[\mathrm{g}]}{\text { Fresh biomass aliquot }[\mathrm{g}]} * \frac{1}{5 * \text { Area soil corer }\left[\mathrm{m}^{2}\right]}
$$

Dry soil was suspended in a $0.1 \mathrm{M} \mathrm{KCl}$ solution (according to ISO 10390 standard), which was used to measure the soil $\mathrm{pH}$.

\section{Determination of root vitality}

Fresh fine roots (approximately 250 root tips per sample) were examined under a stereomicroscope (Leica EZ4HD, Wetzlar, Germany) by counting vital and dead root tips. Black or brown tarnished and visibly distorted root tips were recorded as dead (Comas, Eissenstat, \& Lakso, 2000). Root vitality was determined as:

$$
\text { Root vitality }[\%]=\frac{\text { Number of living root tips }}{\text { Total number of counted root tips }} * 100
$$

\section{Determination of nutrient elements in soil and roots}

Aliquots of oven-dried root and soil samples were ground for one minute in a ball-mill (MM 2000, Retsch, Haan, Germany) and used for elemental analyses. Samples of each subplot were analyzed separately ( $n=3$ per plot and sample type). The total carbon (C) and nitrogen (N) contents were measured by combustion in a CN analyzer (Vario MICRO analyzer, Elementar, Langensbold, Germany). For analyses of the main nutrient elements, including calcium ( $\mathrm{Ca})$, magnesium ( $\mathrm{Mg}$ ), iron (Fe), manganese $(\mathrm{Mn})$, potassium $(\mathrm{K})$, and phosphorus $(\mathrm{P})$, soil and root samples were digested in $65 \% \mathrm{HNO}_{3}$ in a digestion microwave (Ethos Start, Milestone, Sorisole, Italy) for $30 \mathrm{~min}$ at $210{ }^{\circ} \mathrm{C}$. The 
extracts were filtered through an MN 640 WE filter (Macherey und Nagel, Düren, Germany) and measured using inductively coupled plasma mass spectrometry (ICP-OES, iCap 7000, Thermo Fisher Scientific, Waltham, USA).

\section{Preparation data matrices for root and soil chemistry}

Plot means $(n=3)$ were calculated for each variable (nutrient elements, root vitality, root biomass, and soil pH). The plot data are provided in Supplementary Table S 2.2.1. To avoid multicollinearity in the environmental dataset, correlation coefficients and regression plots between all variables were reviewed (Supplementary Figure S 2.2.1). Variables with a Pearson $r$ value of $\geq 0.8$ (root biomass and total $\mathrm{N}$ ) with soil carbon were excluded from further analysis. Resource indices (RI) for cations (Ca, $\mathrm{Mg}, \mathrm{K}, \mathrm{Fe}$, and $\mathrm{Mn}$ ) were determined according to Schröter et al. (2019), for soil and roots separately:

$$
R I_{i}=\frac{C a_{i}}{\overline{C a}}+\frac{M g_{i}}{\overline{M g}}+\frac{K_{i}}{\bar{K}}+\frac{F e_{i}}{\overline{F e}}+\frac{M n_{i}}{\overline{M n}}
$$

All subsequent analyses were performed with a subset of the explanatory variables, including root vitality, soil $\mathrm{pH}, \mathrm{C}, \mathrm{CN}, \mathrm{P}$, and RI. The matrices for root and soil variables were scaled by $\mathrm{z}$-scoring. Principle component analyses were performed for root and soil matrices separately. The first two principal components explained $77.9 \%$ and $79.9 \%$ of the variation in the root and soil chemistry, respectively (Supplementary Figure S 2.2.2). The resulting values were defined as root trait and soil property indices (Supplementary Table S 2.2.1). Pairwise Euclidean distances of the root trait indices were calculated between all plots and used as a distance measure for root trait turnover. Soil property turnover was determined correspondingly.

\section{DNA extraction and Polymerase Chain Reaction (PCR)}

DNA was extracted from freeze-dried, ground, and homogenized soil and root samples from each subplot separately. Root DNA was extracted from $100 \mathrm{mg}$ samples using the innuPREP Plant DNA kit (Analytik Jena AG, Jena, Germany). DNA from soil was extracted from $200 \mathrm{mg}$ samples using the DNeasy PowerSoil Kit (Qiagen, Venlo, Netherlands), following the manufacturer's instructions. The root and soil extractions showed a yellow stain, and direct PCR was unsuccessful. Therefore, the DNeasy PowerClean Cleanup Kit (Qiagen, Venlo, Netherlands) was used, following the manufacturer's instructions, to remove any PCR inhibiting substances, such as phenols, polysaccharides, or humic acids. For the amplification of the fungal ITS1 marker region, the ITS1fKYO2 (Toju, Tanabe, Yamamoto, \& Sato, 2012) and ITS2 (White, Bruns, Lee, \& Taylor, 1990) primer pair with specific overhang adapters for Illumina sequencing were used. PCR was conducted using

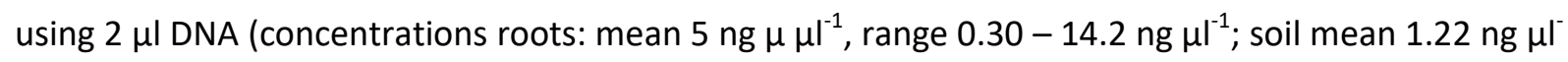

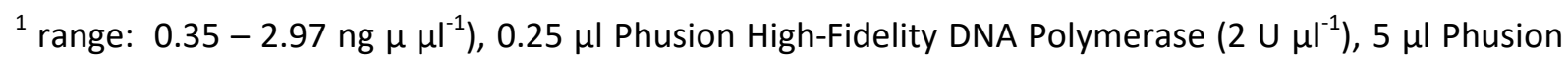
HF reaction Buffer (Thermo Fisher Scientific, Waltham, USA), $0.5 \mu$ of the forward and reverse primer 
each $(10 \mu \mathrm{M}), 0.075 \mu \mathrm{l} \mathrm{MgCl} 2(50 \mathrm{mM})$, and $0.5 \mu \mathrm{l}$ of dNTPs (10 mM). Regarding root samples, $1.25 \mu \mathrm{l}$ bovine serum albumin $\left(8 \mathrm{mg} \mathrm{ml}^{-1}\right)$ and $1.25 \mu \mathrm{l}$ dimethyl sulfoxide (5\%) was added to obtain the maximum amplicon yield, and the reaction mix was adjusted to a total volume of $25 \mu \mathrm{l}$ with dNTP free water. Reactions were performed with an initial heating step of $98{ }^{\circ} \mathrm{C}$ for $30 \mathrm{~s}$, followed by 30 cycles with a $10 \mathrm{~s}$ denaturation phase $\left(98^{\circ} \mathrm{C}\right), 20 \mathrm{~s}$ annealing phase $\left(47^{\circ} \mathrm{C}\right)$, and $20 \mathrm{~s}$ elongation phase $\left(72{ }^{\circ} \mathrm{C}\right)$ (Labcycler, Sensoquest, Göttingen, Germany). Three technical replicates of each sample were performed and pooled after the PCR, to make a final volume of $75 \mu$ l. The product was purified using MagSi-NGSPreb Plus Magnetic Beads (MagnaMedics GmbH, Aachen, Germany), following the manufacturer's instructions, with a ratio of the PCR product and beads solution of $1: 1$, to select for the expected fragment size of 300 to 450 base pairs. Fragment size and amount were checked by gel electrophoresis (110V, $20 \mathrm{~min}$ ) on a $2 \%$ agarose gel stained with GelRed (Biotium, Fremont, USA). GeneRuler 100 bp Plus DNA Ladder (Thermo Fisher Scientific, Waltham, USA) was used as a reference. The concentration of the product was measured using a Qubit 3.0 Fluorometer (Thermo Fisher Scientific, Waltham, USA) and adjusted to a final concentration of $3 \mathrm{ng}^{\mathrm{l}^{-1}}$.

\section{Illumina sequencing and bioinformatic processing}

Amplicon sequencing and OTU assembly were conducted on the MiSeq platform using the MiSeq Reagent Kit v3 (Illumina Inc., San Diego, USA). Raw paired-end reads were merged using PEAR v.0.9.10 (Zhang, Kobert, Flouri, \& Stamatakis, 2014). Subsequently, reads were quality filtered using Trimmomatic v.0.36 (Bolger, Lohse, \& Usadel, 2014). Primer sequences were clipped with cutadapt v.1.16 (Martin, 2014). Reads were cut by a sliding window of 4 if the average quality score dropped below 19, and only sequences with a minimum length of $140 \mathrm{bp}$ were kept. VSEARCH v.2.7.2 (Rognes, Flouri, Nichols, Quince, \& Mahé, 2016) was used for dereplication, denoising (removal of reads with less than 8 occurrences), chimera detection (de-novo followed by reference based), and de-novo OTU clustering at a 97\% similarity threshold. Reads were mapped to the OTU library and used to generate a count table.

OTUs were taxonomically classified using the BLAST algorithm against the UNITE v.7.2 public database (Kõljalg et al., 2013). Unclassified and non-blast hit OTUs were aligned against the GenBank (nt) database (Geer et al., 2010). Only OTUs with a fungal classification were kept in the OTU table. Applying this pipeline, we obtained a total of 5 million sequence reads with 9,279 OTUs in root samples and 4.2 million reads with 13,728 OTUs in soil samples. The counts per OTU of the three subplots were added, resulting in counts per OTU and plot, keeping soil and root counts separate. The root data for plot BF3 are the sum of two subplots, because one subplot yielded insufficient DNA. Subsequently, counts per plot were rarified to 38,021 (the minimum number of counts in a plot) using the $\operatorname{rrarefy}($ ) function of the package vegan v2.5.6 (Oksanen et al., 2019) implemented in $\mathrm{R}$ 
v.3.6.1 (R Core Team, 2019) (Supplementary Table S 2.2.2). Rarefaction resulted in a total of 7,825 and 13,585 OTUs for roots and soil, respectively. Different OTUs were considered as virtual species.

OTUs were functionally annotated as symbiotroph, pathotroph, and saprotroph using the FUNGuild database (Nguyen et al., 2016) as the initial classification. Then the virtual species were manually curated through literature research (Supplementary Table S 2.2.2).

\section{Statistical analysis}

All statistical analyses were performed using R v.3.6.1 (R Core Team, 2019). OTU richness was compared using the Welch test accounting for unequal variances (Welch, 1947), which was implemented using the t.test() function. A linear model for the OTU richness of root and soil fungi in response to the land-use system was built across all plots, as well as for each landscape, and riparian sites individually using the function $\operatorname{Im}($ ). The effects of riparian vs. lowland plots, including an interaction term with land-use systems, were also investigated. The significance of the main effects and interactions was tested using anova(). For pairwise comparisons between land-use systems, the Tukey Test in the glht() function of the package multcomp (Hothorn, Bretz, \& Westfall, 2008) was used. The R package vegan v2.5.6 (Oksanen et al., 2019) was used for Hellinger transformation of the community matrices, to lower the weight of OTUs with low counts and many zeros (Legendre \& Gallagher, 2001), using the function decostand(). Differences in community composition were measured by calculating pairwise Bray-Curtis dissimilarity between all plots with the function vegdist(). The RFC and SFC structure were investigated by two dimensional non-metric multidimensional scaling (NMDS) (Clarke, 1993) using the function metaMDS(). Pairwise dissimilarities of landscape, land-use system, and riparian sites were tested using PERMANOVA with 999 permutations, as implemented in the adonis() function. As riparian plots were only available in the Harapan landscape, the permutations were restricted to the landscape using the strata argument.

The overlap between overall soil and root fungal communities was investigated by a Venn Diagram using the draw.pairwise.venn() function of the VennDiagram package (Chen \& Boutros, 2011). To compare the RFC and SFC, the beta diversity (measured as Sorensen Dissimilarity) between the RFC and SFC of each plot was compartmentalized into a "turnover" component, representing the replacement of OTUs, and a "nestedness" component, representing the loss of OTUs. A high degree of nestedness is to be expected if one community represents a subset of a larger one (Baselga, 2010). For these calculations, the function beta.pair() of the package betapart v.1.5.1 (Baselga, Orme, Villeger, De Bortoli, \& Leprieur, 2018) was used.

Mantel tests were used to investigate the relationships between changes in the fungal community composition and changes in root traits, soil properties, and spatial distances using the mantel() 
function of the ecodist package (Goslee \& Urban, 2007). All combinations were tested using the distance matrices for Bray-Curtis dissimilarities of soil and root fungi and the matrices for root traits, soil properties, and spatial distances. The correlation coefficients of the Mantel statistics were used to compare the responses of the RFC and SFC to changes in root traits, soil properties, and spatial distances. To test whether the SFC responses were different from those of the RFC, a null model approach was used following the suggestions of Anderson et al. (2011) and Wetzel et al. (2012). Fungal community distance matrices were permutated, while keeping the environmental and spatial distance constant, i.e., pairwise Bray-Curtis indices of both communities for a given environmental distance were reassigned to a random community at that given environmental distance. Afterwards, the new absolute distance between the correlation coefficients of the mantel matrix was calculated. This process was repeated with 10,000 iteration steps. The observed absolute difference of the correlation coefficients was considered significant if equal or higher values occurred in less than $5 \%$ of the iteration steps (Supplementary Figure S 2.2.3). We investigated the turnover of complete fungal communities (RFC and SFC) and sub-communities consisting of either saprotrophic, mycorrhizal, or plant pathogenic fungi (Supplementary Table S 2.2.2).

The relative contributions of individual filters (root traits and soil properties) and spatial distance were further investigated using Multiple Regression Models on Distance Matrices (MRM) (Lichstein, 2007). For this, the MRM() function of the ecodist package was used. Pairwise Euclidean distances of all environmental variables and spatial distances were calculated and subsequently centered and scaled by column means using the functions dist() and scale(), respectively. For each community and community subset, a full MRM including all environmental variables was calculated. Non-significant variables were removed stepwise from the model. The explained variation in community composition was partitioned between spatial distance, soil properties, and root trait variables (Krasnov, Mouillot, Shenbrot, Khokhlova, \& Poulin, 2010; Li et al., 2011; Tuomisto, Ruokolainen, \& Ruokolainen, 2012). The coefficient of determination $\left(R^{2}\right)$ was calculated for the full model, including all significant distance matrices. Subsequently, partial models were calculated by excluding either the spatial matrix or all matrices belonging to soil or root traits. The fraction of the overall explained variation (reported in percentage) was calculated following Borcard et al. (1992). 


\section{Results}

\section{Habitat and land-use type affect fungal OTU richness and community composition}

Fungal species richness (OTU-based) in the RFC was approximately three times lower than that in the SFC (Welch Two Sample t $(73.8)=-28.7, p<0.001$; Table 2.2.1). Land transformation from rainforest into oil palm monocultures had negative effects on the fungal species richness (SFC: $F_{3,40}=5.811, p=$ 0.002; RFC: $F_{3,40}=4.683, p=0.007$; Table 2.2.1). However, this decrease was moderate since fungal species richness in both habitats, soil and roots, was approximately $10-20 \%$ lower in oil palm monocultures than in rainforests or jungle rubber (Table 2.2.1). We also found differences in the fungal species richness between the landscapes and among soil types, but these differences were even smaller or similar to those found in response to land transformation (Supplementary Table $S$

\subsection{3).}

Table 2.2.1 Effects of land-use on the OTU richness of the soil fungal community (SFC) and rootassociated fungal community (RFC). Different letters denote significant differences between landuse systems revealed by the Tukey Test

\begin{tabular}{lll}
\hline Land-use system & Mean OTU richness (SFC) & Mean OTU richness (RFC) \\
\hline Forest & $2166 \pm 261(\mathrm{ab})$ & $962 \pm 188(\mathrm{~b})$ \\
Jungle Rubber & $2309 \pm 161(\mathrm{~b})$ & $875 \pm 66(\mathrm{ab})$ \\
Rubber & $2033 \pm 193(\mathrm{a})$ & $811 \pm 146(\mathrm{ab})$ \\
Oil palm & $1940 \pm 192(\mathrm{a})$ & $759 \pm 109(\mathrm{a})$ \\
\hline
\end{tabular}

Strong differences were observed between the species compositions of root and soil fungal communities $\left(R^{2}=0.142, p=0.001\right)$. Both the RFC and SFC were mainly structured by land-use systems, while other factors, such as landscape or riparian sites, had minor effects on the compositions (Table 2.2.2, Supplementary Figure S 2.2.4). 
Table 2.2.2 Effects of landscape with differing soil types, riparian sites, and land-use systems on the soil fungal community (SFC) and root-associated fungal community (RFC) compositions. Significance was tested with a Permutational Multivariate Analysis of Variance (999 permutations) using Bray-Curtis dissimilarity matrices for the two communities. ${ }^{* * *} \mathrm{p}<0.001$; ${ }^{* *} \mathrm{p}<0.01$; df, degrees of freedom; SS, sum of squares; F, pseudo-F value; and $R^{2}$, total explained variation

\begin{tabular}{|c|c|c|c|c|c|c|c|c|}
\hline & \multicolumn{4}{|c|}{ RFC } & \multicolumn{4}{|c|}{ SFC } \\
\hline & $\mathrm{df}$ & SS & $\mathrm{F}$ & $\mathrm{R}^{2}$ & $\mathrm{df}$ & SS & $\mathrm{F}$ & $\mathrm{R}^{2}$ \\
\hline Landscape & 1 & 0.604 & 3.042 & $0.051 * * *$ & 1 & 0.587 & 2.548 & $0.044^{* * *}$ \\
\hline Riparian & 1 & 0.556 & 2.798 & $0.047^{* *}$ & 1 & 0.528 & 2.293 & $0.040 * *$ \\
\hline Land-use & 3 & 3.112 & 5.224 & $0.263 * * *$ & 3 & 3.397 & 4.918 & $0.256 * * *$ \\
\hline Residual & 38 & 7.547 & & 0.644 & 38 & 8.751 & & 0.661 \\
\hline
\end{tabular}

\section{Recruitment patterns of root fungi from soil are stable}

Across all plots, we found $44 \%$ of the OTUs $(6,215)$ exclusively in soil, $56 \%(7,370)$ shared between roots and soil, and only a small portion (3\%) of OTUs (455) exclusively in roots (Figure 2.2.1 A). We expected that RFCs in a given plot were recruited from the surrounding soil of the same plot, which would result in high nestedness. To examine this expectation, we partitioned the beta diversity into a nestedness and turnover component (Baselga, 2010). Regardless of the land-use system, the total beta diversity between the soil and root compartments within a plot was stable (mean 0.664; ANOVA, $F_{3,40}=2.683, p=0.060$; Figure 2.2.1 B). Between the SFC and RFC, approximately one third of the beta diversity was associated with nestedness (mean $=0.252$; ANOVA, $F_{3,40}=1.515, p=0.225$ ) and two thirds were explained by turnover (mean $=0.410$; Figure 2.2.1 B), indicating that the structures of fungal assemblages were more strongly determined by replacement than by species loss. 

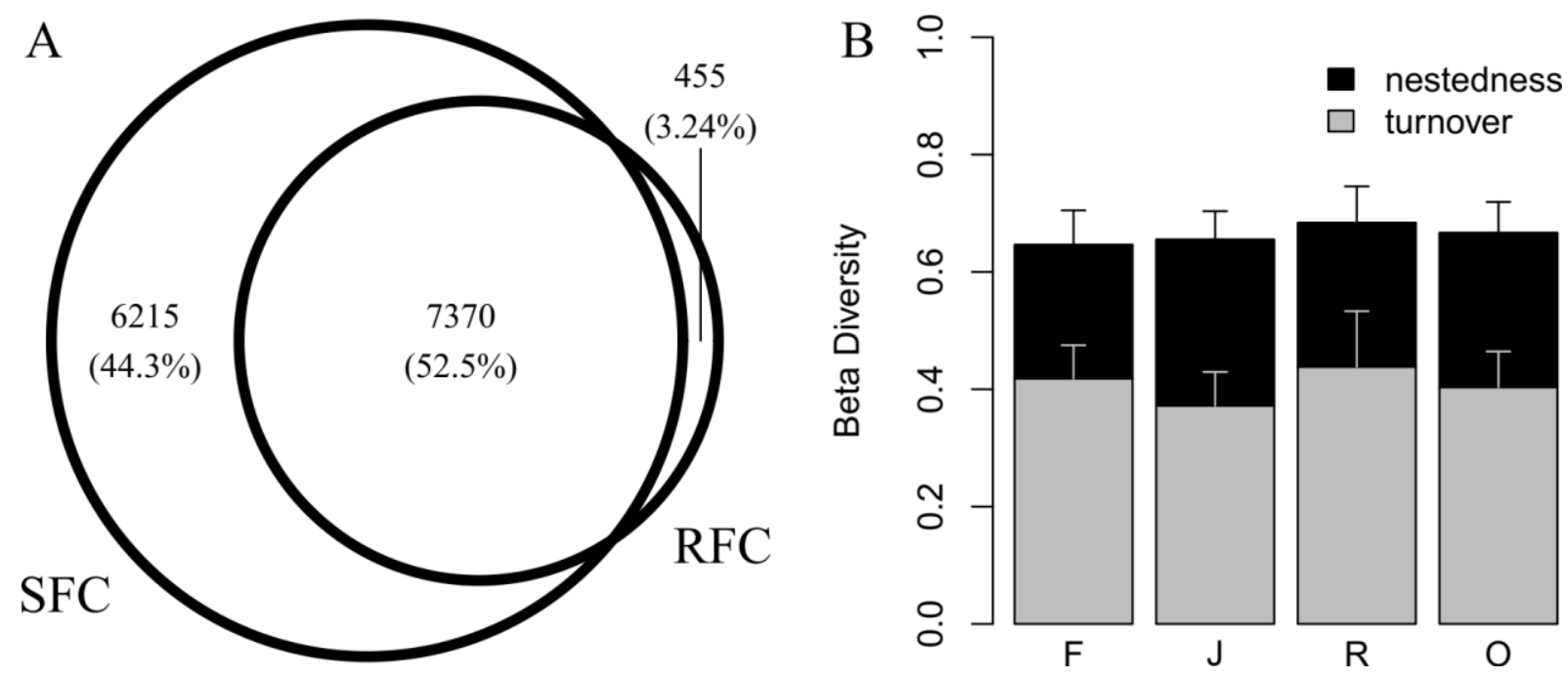

Figure 2.2.1 A: A: Number of fungal OTUs found in the soil (SFC), roots (RFC), and within both habitats across all plots. B: Mean beta diversity (measured as Sorensen Dissimilarity) between the root and soil fungal communities within a plot $(n=12$ for forest, rubber, and oil palm; $n=8$ for jungle rubber). Beta diversity was split into a nestedness component, driven by the loss of species between the root and soil communities, and a turnover component, driven by the replacement of species with others between the root and soil communities. $F=$ forest, $J=$ jungle rubber, $R=$ rubber, and $\mathrm{O}=$ oil palm

\section{Changes in root and soil chemistry have divergent effects on fungal turnover in roots and soil}

We anticipated that changes in soil chemistry, root chemistry, and geographic distance influenced the turnover of fungal community structures in soils and roots. To assess the impacts of these potential drivers on the turnover of RFCs, SFCs, and functional groups (mycorrhiza, saprotrophs, and plant pathogens) in the RFCs and SFCs, we conducted Mantel tests. The turnover of RFCs, SFCs, and the functional groups (mycorrhiza, saprotrophs, and plant pathogens) in the soil and roots were significantly related to changes in the root and soil chemistry and to spatial distance (Figure 2.2.2). Overall, we found higher dissimilarity in the RFC than the SFC (Figure 2.2.2). Moreover, we detected significant differences for the spatial distance, root chemistry, and soil chemistry between the RFC and SFC, and distinct responses of functional groups (Figure 2.2.2). Firstly, geographic distance had a stronger impact on the SFC than the RFC, regardless of whether the whole communities or functional groups were inspected (Figure 2.2.2 A, D, G, and J). The strongest difference between the soil and root fungal turnover was found for mycorrhizal fungi $\left(\Delta r=0.169^{* * *}\right.$, Figure 2.2.2 D). Secondly, changes in soil properties drove the turnover of whole fungal communities and functional groups in the soil to an extent that was similar to that in roots (Figure 2.2.2 B, E, and K). However, only saprotrophs in the soil showed a stronger response to changes in soil chemistry than saprotrophs on roots (Figure 2.2.2 H). Thirdly, changes in root traits caused a stronger turnover in the RFC than the 
SFC. Thereby, the dissimilarities between the SFC and RFC diverged with increasing root trait distance (Figure 2.2.2 C). These effects were more prominent in the mycorrhizal fungal community than in whole RFCs and SFCs (Figure 2.2.2 F). In contrast, changes in root traits caused converging effects in the plant pathogens (Figure 2.2.2 I), suggesting the homogenization of the soil and root-associated communities when the trait distance of roots was large.

To evaluate our findings from simple matrix regressions and dissect the influence of individual drivers, we used a multiple distance matrix regression model (MRM). After the stepwise removal of non-significant variables, we found that the spatial distance, soil $\mathrm{pH}$, and root vitality were significant factors influencing SFCs, RFCs, and each of the fungal sub-communities (Figure 2.2.3 A). In agreement with our Mantel tests (Figure 2.2.2), mycorrhizal community structures in soil showed a strong spatial effect, almost twice as high as in saprotrophs, whereas distance effects were smallest in the rootassociated mycorrhizal community (Figure 2.2.3 B). However, the fraction of variance explained by spatial distance was small compared to that explained by root and soil factors or shared effects (Figure 2.2.3 B). The soil pH was the strongest driver for the composition of all fungal communities studied here (Figure 2.2.3 A). The soil resource index, representing the nutrient cations in the soil, affected saprotrophic fungi on roots and plant pathogens in the soil and roots (Figure 2.2.3 A). Mycorrhizal assemblages were driven by soil phosphorus, at the roots more strongly than in soil (Figure 2.2.3 A). Among the tested root traits, the RFC was strongly filtered by root $\mathrm{C} / \mathrm{N}$, whereas the SFC was neither affected by soil $\mathrm{C} / \mathrm{N}$ nor by root $\mathrm{C} / \mathrm{N}$ (Figure 2.2.3 A). Furthermore, we found significant effects of root vitality on all tested fungal assemblages, which highlights that root traits did not only affect root-associated fungal assemblages but also soil fungi (Figure 2.2.3 A). Root phosphorus and the root resource index also affected the assemblage of the saprotrophic fungi in the soil (Figure 2.2.3 A). Overall, variance partitioning showed that changes in soil chemistry had a stronger effect on the SFC than the RFC, and that the RFC was more strongly affected by changes in root traits (Figure 2.2.3 B). 

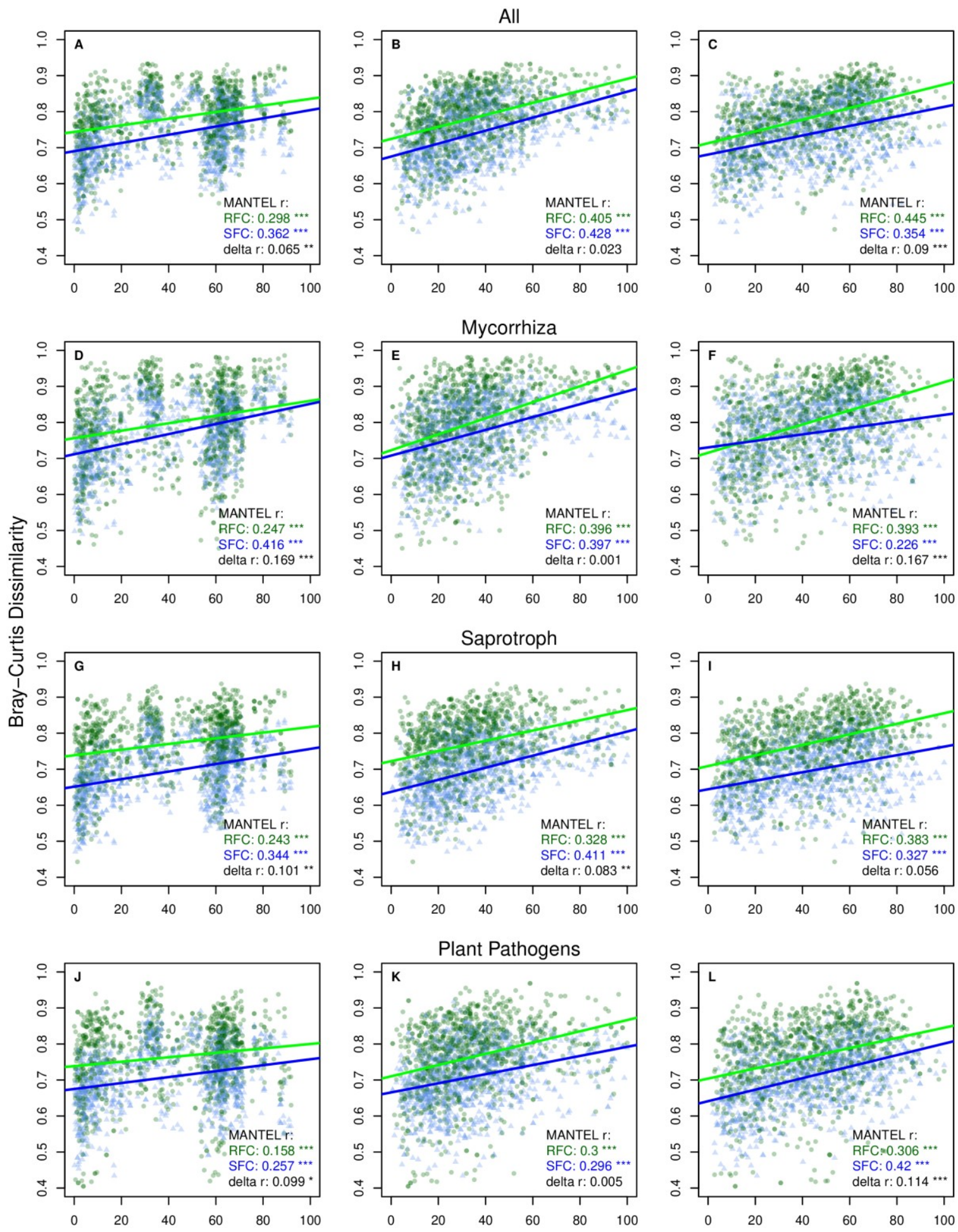

Spatail Distance $[\mathrm{km}]$
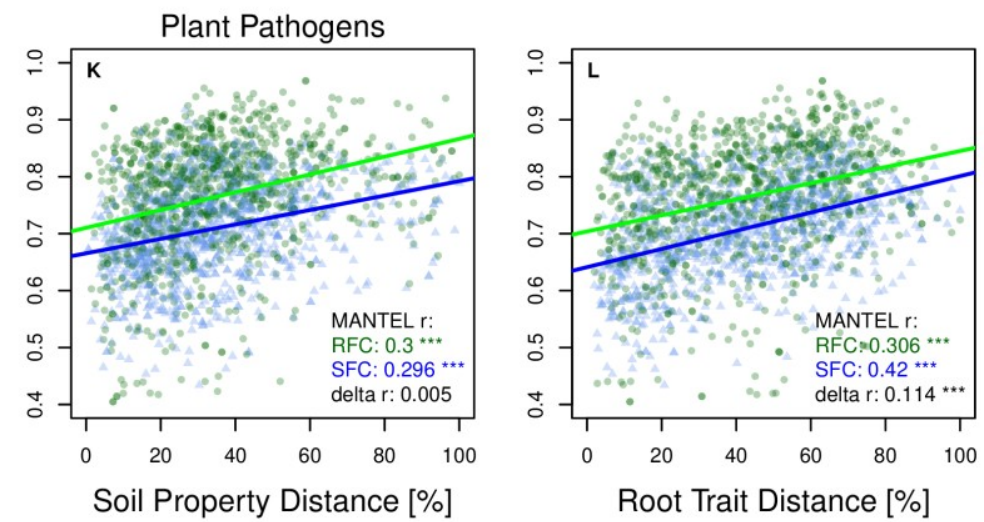

Figure 2.2.2 Pairwise community dissimilarity between fungal community composition and the spatial (A, D, G, and J), soil property (B, E, H, and K), and root trait distances (C, F, I, and L). Blue: soil fungal community (SFC) and green: root-associated fungal community (RFC). Models were calculated for the whole fungal community $(A-C)$, mycorrhiza fungi $(D-F)$, saprotrophs $(G-I)$, and plant pathogens $(J-K)$. Regression coefficients $(r)$ and mantel test significance are shown for both communities. Delta represents the differences in the correlation coefficients between the two communities. Significance was tested using a null model approach with 10000 iteration steps $\left({ }^{*} p<\right.$ $\left.0.05 ;^{* *} \mathrm{p}<0.01{ }^{* * *} \mathrm{p}<0.001\right)$ 


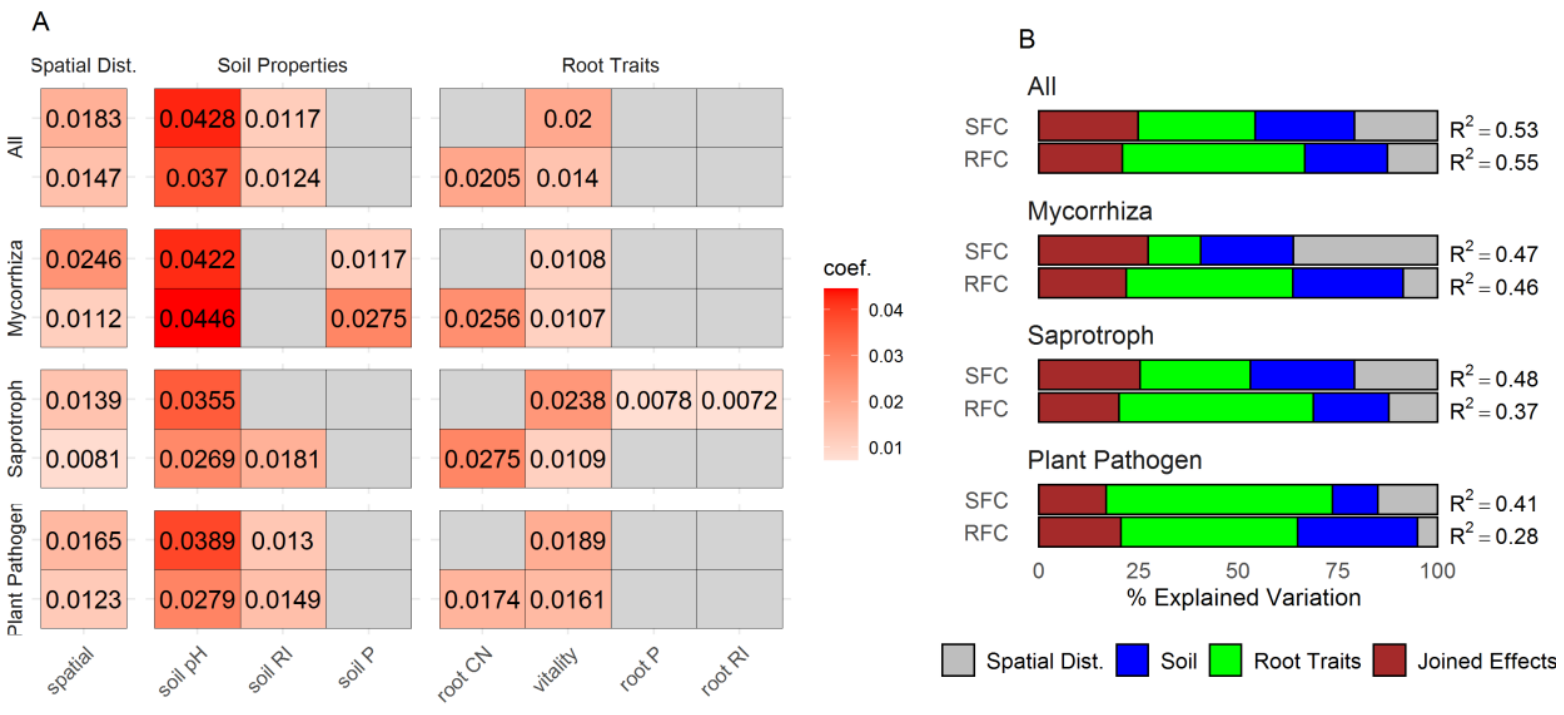

Figure 2.2.3 Multiple regression models on distance matrices (MRM) showing the effects of changes in the spatial distance, soil properties, and root traits on the fungal community composition. Models for the soil (SFC) and root-associated fungi (RFC) were calculated for the whole community as well as mycorrhizas, saprotrophs, and plant pathogens. Non-significant environmental drivers were step-wise excluded from models. A: Regression coefficients of all distance matrices retained in the models. Grey fields indicate no significant contribution to the model. B: Variation partitioning of models showing the percentage of explained variation in community change, explained by changes in spatial, soil property, and root trait distances. $R^{2}$ indicates the total explained variation by the models 


\section{Discussion}

High turnover between local root and soil fungal communities underpins structuring effect of root chemistry on fungal assemblages

In this study, we investigated the fungal turnover (beta-diversity) of root- and soil-residing fungi across tropical land-use systems. In agreement with previous microbiome studies in tropical land-use systems (Berkelmann et al., 2020; Brinkmann et al., 2019; Grass et al., 2020; Kerfahi et al., 2016; McGuire et al., 2015) we found only moderate or no species loss for soil fungal communities in response to land-use changes. At first glance, this observation may be surprising because vegetation is a driver of fungal communities (de Vries et al., 2012; Peay et al., 2013) and the overall decline in plant species richness across our land-use systems was approximately 60\% (Rembold et al., 2017). Tree species richness decreased even from approximately 80 species per plot in rainforests to only one species in plantations (Rembold et al., 2017). Therefore, we expected a strong loss of rootassociated fungal species, providing that plant species identity was a major driver for fungal host colonization. In contrast to this expectation, the turnover of root fungal communities, instead of species loss, was the main response to the intensification of land-use. Our results support that changes in environmental conditions create new niches that can be occupied by the propagules present in an ecosystem.

It is currently under discussion whether host chemistry or host phylogenetic diversity drive microbial community structures (Anacker, Klironomos, Maherali, Reinhart, \& Strauss, 2014; de Vries et al., 2012; Leff et al., 2018; Mehrabi \& Tuck, 2015; Münzbergová \& Šurinová, 2015; Wilschut et al., 2019). On the one hand, mycorrhizal community structure is linked to the vegetation type (Geml, Morgado, Semenova-Nelsen, \& Schilthuizen, 2017; Rodríguez-Echeverría et al., 2017). On the other hand, in tropical regions mycorrhizal community shows low host specificity and is strongly impacted by abiotic factors (Peay et al., 2015; Schappe et al., 2017). Therefore, Peay et al. (2015) suggested that plant and mycorrhizal community compositions might not be directly related, but are driven by the same abiotic gradient. Our study supports a different mechanism involving host chemistry. We demonstrated a strong relationship between the root chemistry and RFC turnover. Therefore, we conclude that root traits represent an important ecological driver.

Roots have a lower fungal species richness than local soil (this study, Danielsen et al., 2012; Goldmann et al., 2016; Zheng, Hu, Guo, Anderson, \& Powell, 2017), which is likely due to the selecting effects of roots on the associated microbiome (Danielsen et al., 2012; Edwards et al., 2015; Gottel et al., 2011). Over the whole geographic scale of our study, root-associated fungi were a subgroup of soil-residing fungi, supporting that soil is a reservoir for the root fungal assemblage ("fungal seed bank", Lennon and Jones 2011). However, at the plot-level we observed a low 
nestedness and high turnover proportion. These results contradict our initial hypothesis that the fungi colonizing roots are sampled from the local soil community. Instead, the structuring effects of plant roots on their fungal communities were partially independent of neighboring soil fungal communities. This finding highlights the need to investigate the turnover of soil and root fungal communities separately. Moreover, our results imply that far-distance dispersal of fungal species present in the wider landscape can significantly contribute to the assembly of the local RFC. This result is highly relevant for biodiversity conservation because it suggests that forest remnants in the landscape may serve as a source for naturally occurring fungal species and could contribute towards re-colonizing recovering ecosystems after anthropogenic land-use.

\section{Root chemistry has divergent effects on different trophic fungal groups}

A major goal of this study was to evaluate the drivers of three ecologically important fungal groups: mycorrhizas, saprotrophs, and plant pathogens. In line with other studies (Goldmann et al., 2016; Green et al., 2004; Zhao et al., 2019), increasing geographic distance resulted in a reduction in the similarities between fungal communities. Distance decay involves intrinsic factors of spreading species, like niche occupation and neutral processes, such as natural dispersal limitations or stochastic events (Rosindell, Hubbell, \& Etienne, 2011; Zinger et al., 2019). Previous studies have highlighted the strong stochasticity of fungal community assemblies (Powell et al., 2015; Zhao et al., 2019) and selective effects of roots (Deveautour, Donn, Power, Bennett, \& Powell, 2018; Goldmann et al., 2016; Gottel et al., 2011; Wilschut et al., 2019). For example, across a biogeographic gradient in temperate ecosystems, the distance decay of the ectomycorrhizal community structures on beech (Fagus sylvatica) roots was lower compared to that found in soil (Goldmann et al., 2016). The "stabilization" of fungal communities was ascribed to the host selectivity of ectomycorrhizal fungi in temperate forests (Goldmann et al., 2016; van der Linde et al., 2018). However, in tropical ecosystems, where arbuscular mycorrhizal fungi dominate, host selectivity is generally low (Peay et al., 2015). In our study, host plant identities were obviously not involved in mediating the RFC turnover, which was lower than that of the SCF, because we included samples from widely differing ecosystems, where the vegetation ranged from tree monocultures to tropical rainforests. This result implies that certain root properties, and not their phylogenetic diversity, drives fungal turnover. Another important result was that the distance decay of the RFC was lessened because of mycorrhizal fungi in these assemblages, highlighting selective plant effects. Notably, pathogens and saprotrophs showed similar behavior, indicating that those fungal groups might also be subject to selective plant effects. Thus, our findings highlight that the features of plant root communities structure fungal communities. 
Although our study demonstrates the significant effects of spatial scales on fungal community structures, geographic distance explained only a minor fraction of the variance. The relative contribution of ecological factors was by far stronger. Fungal community shifts in tropical habitats have been linked to variation in edaphic properties, such as $\mathrm{pH}$, carbon, nitrogen, and phosphorus (Barnes et al., 2016; Camenzind, Hättenschwiler, Treseder, Lehmann, \& Rillig, 2018; McGee, Eaton, Shokralla, \& Hajibabaei, 2018; Tedersoo et al., 2014). We found a strong structuring effect of soil pH on the SFC and RFC, which is in line with current studies suggesting that soil $\mathrm{pH}$ is a unifying driver for belowground microbiomes (Fierer, 2017; Glassman, Wang, \& Bruns, 2017; Tedersoo et al., 2014). In addition, the mycorrhizal community structures in both the soil and roots were affected by soil phosphorus, which corresponds well to their role in improvement in the host phosphorus supply (Smith, Jakobsen, Grønlund, \& Smith, 2011). Withered soils in many tropical ecosystems are strongly phosphorus-limited (Turner et al. 2018), and so the effects of soil phosphorus on mycorrhizal community structures are not surprising. Overall, we demonstrated that increasing distance of soil chemistry drives a similar turnover of soil and root fungal communities, including mycorrhizal fungi and plant pathogens. Thereby, our results confirm the strong regulatory effects of edaphic properties for a large fraction of belowground fungal communities, regardless of whether they colonize soils or roots. However, there was one notable exception, i.e., the turnover of saprotrophic fungi, which showed divergent turnover in the soil and roots. The reason for this unexpected behavior is perhaps because root chemistry had feedback effects on the turnover of soil-residing fungi. All fungal groups were significantly structured by root vitality. This effect was probably further augmented by the additional effects of root resources (cations and phosphorus) on the turnover of saprotrophs in soil. It is plausible that fine roots with high turnover rates in tropical systems are an important source of nutrients (Finér, Ohashi, Noguchi, \& Hirano, 2011; Kotowska, Leuschner, Triadiati, Meriem, \& Hertel, 2015), which may foster saprotrophs more specifically than other fungal communities.

An important result was that all root-associated fungal groups, but not soil-residing fungi, were strongly structured by the root $\mathrm{C} / \mathrm{N}$. The allocation of primary production towards roots is substantial in tropical forest ecosystems (Clark et al., 2001; Malhi, Doughty, \& Galbraith, 2011), and plantation management involves the significant input of fertilizers (Darras et al., 2019; Kurniawan et al., 2018). Therefore, root $\mathrm{C} / \mathrm{N}$ ratios differ significantly among different land-use systems (Edy, Yelianti, Irawan, Polle, \& Pena, 2020; Sahner et al., 2015). Our results show that changes in the quality of this trait were directly linked to changes in the community structures of all groups of root-associated fungi. Obviously, altered root traits drive root-associated fungal community structures - at least partly independent of edaphic properties. This result supports our initial hypothesis that RFCs undergo a double filter process, initially driven by edaphic properties and secondly by plant root community 
traits. Our study highlights the need to independently investigate the assembly processes of microbial communities from different belowground habitats.

\section{Conclusion}

Our study provides important insights into the mechanisms of fungal community assembly under tropical land-use conditions, emphasizing the bottom-up regulatory effects of plant community traits on fungal turnover. We showed that root- and soil-associated fungal communities are distinct and that environmental filters differ in their relative importance of driving the assembly of those communities. Soil fungal communities present in the landscape may serve as a pool for colonizing plant roots via long distance dispersal. Root traits can stabilize the associated fungal community against stochastic community shifts and changes in edaphic conditions. The recovery of degraded root traits in intensively managed landscapes by managing the root $\mathrm{C} / \mathrm{N}$ ratio and root health may help to moderate the land-use induced loss of naturally occurring communities and improve resilience against changes in soil properties. 


\section{Literature}

Adams, R. I., Miletto, M., Taylor, J. W., \& Bruns, T. D. (2013). Dispersal in microbes: Fungi in indoor air are dominated by outdoor air and show dispersal limitation at short distances. The ISME Journal, 7(7), 1262-1273. doi: 10.1038/ismej.2013.28

Allen, K., Corre, M. D., Tjoa, A., \& Veldkamp, E. (2015). Soil nitrogen-cycling responses to conversion of lowland forests to oil palm and rubber plantations in Sumatra, Indonesia. PLOS ONE, 10(7), e0133325. doi: 10.1371/journal.pone.0133325

Anacker, B. L., Klironomos, J. N., Maherali, H., Reinhart, K. O., \& Strauss, S. Y. (2014). Phylogenetic conservatism in plant-soil feedback and its implications for plant abundance. Ecology Letters, 17(12), 1613-1621. doi: 10.1111/ele.12378

Anderson, M. J., Crist, T. O., Chase, J. M., Vellend, M., Inouye, B. D., Freestone, A. L., sanders, N. J., Cornell, H. V., Comita, L. S., Davies, K. F., Harrison, S. P., Kraft, N. J. B., Stegen, J. C., \& Swenson, N. G. (2011). Navigating the multiple meanings of $\beta$ diversity: A roadmap for the practicing ecologist: Roadmap for beta diversity. Ecology Letters, 14(1), 19-28. doi: 10.1111/j.1461-0248.2010.01552.x

Bahram, M., Hildebrand, F., Forslund, S. K., Anderson, J. L., Soudzilovskaia, N. A., Bodegom, P. M., BengtssonPalme, J., Anslan, S., Coelho, L. P., Harend, H., Huerta-Cepas, J., Medema, M. H., Maltz, M. R., Mundra, S., Olsson, P. A., Pent, M., Põlme, S., Sunagawan, S., Ryberg, M., Tedersoo, L., \& Bork, P. (2018). Structure and function of the global topsoil microbiome. Nature, 560(7717), 233-237. doi: 10.1038/s41586-018-0386-6

Barberán, A., McGuire, K. L., Wolf, J. A., Jones, F. A., Wright, S. J., Turner, B. L., Essen, A., Hubbell, S. P., Faircloth, B. C., Fierer, N. (2015). Relating belowground microbial composition to the taxonomic, phylogenetic, and functional trait distributions of trees in a tropical forest. Ecology Letters, 18(12), 1397-1405. doi: 10.1111/ele.12536

Barnes, C. J., Maldonado, C., Frøslev, T. G., Antonelli, A., \& Rønsted, N. (2016). Unexpectedly high beta-diversity of root-associated fungal communities in the Bolivian Andes. Frontiers in Microbiology, 7. doi: 10.3389/fmicb.2016.01377

Baselga, A. (2010). Partitioning the turnover and nestedness components of beta diversity. Global Ecology and Biogeography, 19(1), 134-143. doi: 10.1111/j.1466-8238.2009.00490.x

Baselga, A., Orme, D., Villeger, S., De Bortoli, J., \& Leprieur, F. (2018). betapart: Partitioning beta diversity into turnover and nestedness components. R package version 1.5.1.

Berkelmann, D., Schneider, D., Meryandini, A., \& Daniel, R. (2020). Unravelling the effects of tropical land use conversion on the soil microbiome. Environmental Microbiome, 15(1), 5. doi: 10.1186/s40793-0200353-3

Bolger, A. M., Lohse, M., \& Usadel, B. (2014). Trimmomatic: A flexible trimmer for Illumina sequence data. Bioinformatics, 30(15), 2114-2120. doi: 10.1093/bioinformatics/btu170

Borcard, D., Legendre, P., \& Drapeau, P. (1992). Partialling out the spatial component of ecological variation. Ecology, 73(3), 1045-1055. doi: 10.2307/1940179

Brinkmann, N., Schneider, D., Sahner, J., Ballauff, J., Edy, N., Barus, H., Irawan, B., Budi, S. W., Qaim, M., Daniel, R., \& Polle, A. (2019). Intensive tropical land use massively shifts soil fungal communities. Scientific Reports, 9(1), 3403. doi: 10.1038/s41598-019-39829-4

Broeckling, C. D., Broz, A. K., Bergelson, J., Manter, D. K., \& Vivanco, J. M. (2008). Root exudates regulate soil fungal community composition and diversity. Applied and Environmental Microbiology, 74(3), 738744. doi: 10.1128/AEM.02188-07

Camenzind, T., Hättenschwiler, S., Treseder, K. K., Lehmann, A., \& Rillig, M. C. (2018). Nutrient limitation of soil microbial processes in tropical forests. Ecological Monographs, 88(1), 4-21. doi: 10.1002/ecm.1279

Chen, H., \& Boutros, P. C. (2011). VennDiagram: A package for the generation of highly-customizable Venn and Euler diagrams in R. BMC Bioinformatics, 12(1), 35. doi: 10.1186/1471-2105-12-35

Clark, D. A., Brown, S., Kicklighter, D. W., Chambers, J. Q., Thomlinson, J. R., Ni, J., \& Holland, E. A. (2001). Net primary production in tropical forests: An evaluation and synthesis of existing field data. Ecological Applications, 11(2), 371-384. 
Clarke, K. R. (1993). Non-parametric multivariate analyses of changes in community structure. Australian Journal of Ecology, 18(1), 117-143. doi: 10.1111/j.1442-9993.1993.tb00438.x

Clemmensen, K. E., Bahr, A., Ovaskainen, O., Dahlberg, A., Ekblad, A., Wallander, H., Stenlid, J., Finlay, R. D., Wardle, D. A., \& Lindahl, B. D. (2013). Roots and associated fungi drive long-term carbon sequestration in boreal forest. Science, 339(6127), 1615-1618. doi: 10.1126/science.1231923

Comas, L. H., Eissenstat, D. M., \& Lakso, A. N. (2000). Assessing root death and root system dynamics in a study of grape canopy pruning: RESEARCH Assessing root mortality and decomposition. New Phytologist, 147(1), 171-178. doi: 10.1046/j.1469-8137.2000.00679.x

Danielsen, L., Thürmer, A., Meinicke, P., Buée, M., Morin, E., Martin, F., Pilate, G., Daniel, R., Polle, A., Reich, M. (2012). Fungal soil communities in a young transgenic poplar plantation form a rich reservoir for fungal root communities. Ecology and Evolution, 2(8), 1935-1948. doi: 10.1002/ece3.305

Darras, K. F. A., Corre, M. D., Formaglio, G., Tjoa, A., Potapov, A., Brambach, F., Sibhatu, K. T., Grass, I., Rubiano, A. A., Buchori, D., Drescher, J., Fardiansah, R., Hölscher, D., Irawan, B., Kneib, T., Krashevska, V., Krause, A., Kreft, H., Li, K., Maraun, M., Polle, A., Ryadin, A. R., Rembold, K., Stiegler, C., Scheu, S., Tarigan, S., Valdés-Uribe, A., Yadi, S., Tscharntke, T., \& Veldkamp, E. (2019). Reducing fertilizer and avoiding herbicides in oil palm plantations-ecological and economic valuations. Frontiers in Forests and Global Change, 2. doi: 10.3389/ffgc.2019.00065

de Vries, F. T. de, Manning, P., Tallowin, J. R. B., Mortimer, S. R., Pilgrim, E. S., Harrison, K. A., Hobbs, P. J., Quirk, H., Shipley, B., Cornelissen, J. H. C., Kattge, J., \& Bardgett, R. D. (2012). Abiotic drivers and plant traits explain landscape-scale patterns in soil microbial communities. Ecology Letters, 15(11), 12301239. doi: 10.1111/j.1461-0248.2012.01844.x

Deveautour, C., Donn, S., Power, S. A., Bennett, A. E., \& Powell, J. R. (2018). Experimentally altered rainfall regimes and host root traits affect grassland arbuscular mycorrhizal fungal communities. Molecular Ecology, 27(8), 2152-2163. doi: 10.1111/mec.14536

Drescher, J., Rembold, K., Allen, K., Beckschäfer, P., Buchori, D., Clough, Y., Faust, H., Fauzi, A. M., Gunawan, D., \& Hertel, D. (2016). Ecological and socio-economic functions across tropical land use systems after rainforest conversion. Phil. Trans. R. Soc. B, 371(1694), 20150275.

Edwards, J., Johnson, C., Santos-Medellín, C., Lurie, E., Podishetty, N. K., Bhatnagar, S., Eisen, J. A., \& Sundaresan, V. (2015). Structure, variation, and assembly of the root-associated microbiomes of rice. Proceedings of the National Academy of Sciences, 112(8), E911-E920. doi: 10.1073/pnas.1414592112

Edy, N., Yelianti, U., Irawan, B., Polle, A., \& Pena, R. (2020). Differences in root nitrogen uptake between tropical lowland rainforests and oil palm plantations. Frontiers in Plant Science, 11. doi: 10.3389/fpls.2020.00092

Fierer, N. (2017). Embracing the unknown: Disentangling the complexities of the soil microbiome. Nature Reviews Microbiology, 15(10), 579-590. doi: 10.1038/nrmicro.2017.87

Finér, L., Ohashi, M., Noguchi, K., \& Hirano, Y. (2011). Fine root production and turnover in forest ecosystems in relation to stand and environmental characteristics. Forest Ecology and Management, 262(11), 20082023. doi: $10.1016 / j$.foreco.2011.08.042

Frąc, M., Hannula, S. E., Bełka, M., \& Jędryczka, M. (2018). Fungal Biodiversity and their role in soil health. Frontiers in Microbiology, 9. doi: 10.3389/fmicb.2018.00707

Gao, C., Shi, N.-N., Chen, L., Ji, N.-N., Wu, B.-W., Wang, Y.-L., Xu, Y., Zheng, Y., Mi, K.-P., \& Guo, L.-D. (2017). Relationships between soil fungal and woody plant assemblages differ between ridge and valley habitats in a subtropical mountain forest. New Phytologist, 213(4), 1874-1885. doi: 10.1111/nph.14287

García-Guzmán, G., \& Heil, M. (2014). Life histories of hosts and pathogens predict patterns in tropical fungal plant diseases. New Phytologist, 201(4), 1106-1120. doi: 10.1111/nph.12562

Gaston, K. J. (2000). Global patterns in biodiversity. Nature, 405, 220-227.

Geer, L. Y., Marchler-Bauer, A., Geer, R. C., Han, L., He, J., He, S., Liu, C., Shi, W., \& Bryant, S. H. (2010). The NCBI BioSystems database. Nucleic Acids Research, 38, D492-D496. doi: 10.1093/nar/gkp858

Geml, J., Morgado, L. N., Semenova-Nelsen, T. A., \& Schilthuizen, M. (2017). Changes in richness and community composition of ectomycorrhizal fungi among altitudinal vegetation types on Mount Kinabalu in Borneo. New Phytologist, 215(1), 454-468. doi: 10.1111/nph.14566 
Glassman, S. I., Wang, I. J., \& Bruns, T. D. (2017). Environmental filtering by pH and soil nutrients drives community assembly in fungi at fine spatial scales. Molecular Ecology, 26(24), 6960-6973. doi: 10.1111/mec.14414

Goldmann, K., Schröter, K., Pena, R., Schöning, I., Schrumpf, M., Buscot, F., Polle, A., \& Wubet, T. (2016). Divergent habitat filtering of root and soil fungal communities in temperate beech forests. Scientific Reports, 6(1). doi: 10.1038/srep31439

Goslee, S. C., \& Urban, D. L. (2007). The ecodist Package for dissimilarity-based analysis of ecological data. Journal of Statistical Software, 22(1), 1-19. doi: 10.18637/jss.v022.i07

Gottel, N. R., Castro, H. F., Kerley, M., Yang, Z., Pelletier, D. A., Podar, M., Karpinets, T., Uberbacher, E., Tuskan, G. A., Vilgalys, R., Doktycz, M. J., \& Schadt, C. W. (2011). Distinct microbial communities within the endosphere and rhizosphere of Populus deltoides roots across contrasting soil types. Applied and Environmental Microbiology, 77(17), 5934-5944. doi: 10.1128/AEM.05255-11

Grass, I., Kubitza, C., Krishna, V. V., Corre, M. D., Mußhoff, O., Pütz, P., Drescher, J., Rembold, K., Ariyanti, E. S., Barnes, A. D., Brinkmann, N., Brose, U., Brümmer, B., Buchori, D., Daniel, R., Darras, K. F. A., Faust, H., Fehrmann, L., Hain, J., Hennings, N., Hidayat, P., Hölscher, D., Jochum, M., Knohl, A., Kotowska, M. M., Krashevska, V., Kreft, H., Leuschner, C., Lobite, N. J. S., Panjaitan, R., Polle, A., Potapov, A. M., Purnama, E., Qaim, M., Röll, A., Scheu, S., Schneider, D., Tjoa, A., Tscharntke, T., Veldkamp, E., \& Wollni, M. (2020). Trade-offs between multifunctionality and profit in tropical smallholder landscapes. Nature Communications, 11(1), 1-13. doi: 10.1038/s41467-020-15013-5

Green, J. L., Holmes, A. J., Westoby, M., Oliver, I., Briscoe, D., Dangerfield, M., Gillings, M., \& Beattie, A. J. (2004). Spatial scaling of microbial eukaryote diversity. Nature, 432(7018), 747-750. doi: 10.1038/nature03034

Gregory, S. V., Swanson, F. J., McKee, W. A., \& Cummins, K. W. (1991). An ecosystem perspective of riparian zones. BioScience, 41(8), 540-551. doi: 10.2307/1311607

Hothorn, T., Bretz, F., \& Westfall, P. (2008). Simultaneous inference in general parametric models. Biometrical Journal. Biometrische Zeitschrift, 50(3), 346-363. doi: 10.1002/bimj.200810425

Johnson, N. C., Angelard, C., Sanders, I. R., \& Kiers, E. T. (2013). Predicting community and ecosystem outcomes of mycorrhizal responses to global change. Ecology Letters, 16(s1), 140-153. doi: 10.1111/ele.12085

Kerfahi, D., Tripathi, B. M., Dong, K., Go, R., \& Adams, J. M. (2016). Rainforest conversion to rubber plantation may not result in lower soil diversity of bacteria, fungi, and nematodes. Microbial Ecology, 72(2), 359371. doi: 10.1007/s00248-016-0790-0

Kerfahi, D., Tripathi, B. M., Lee, J., Edwards, D. P., \& Adams, J. M. (2014). The impact of selective-logging and forest clearance for oil palm on fungal communities in Borneo. PLOS ONE, 9(11), e111525. doi: 10.1371/journal.pone.0111525

Koh, L. P., Levang, P., \& Ghazoul, J. (2009). Designer landscapes for sustainable biofuels. Trends in Ecology \& Evolution, 24(8), 431-438. doi: 10.1016/j.tree.2009.03.012

Kõljalg, U., Nilsson, R. H., Abarenkov, K., Tedersoo, L., Taylor, A. F. S., Bahram, M., Bates, S. T., Bruns, T. D., Bengtsson-Palme, J., Callaghan, T. M., Douglas, B., Drenkhan, T., Eberhardt, U., Dueñas, M., Grebenc, T., Griffith, G. W., Hartmann, M., Kirk, P. M., Kohout, P., Larsson, E., Lindahl, B. D., Lücking, R., Martín, M. P., Matheny, P. B., Nguyen, N. H., Niskanen, T., Oja, J., Peay, K. G., Peintner, U., Peterson, M., Põldmaa, K., Saag, L., Saar, I., Schüßler, A., Scott, J. A., Senés, C., Smith, M. E., Suija, A., Taylor, D. L., Telleria, M. T., Weiss, M., \& Larsson, K.-H. (2013). Towards a unified paradigm for sequence-based identification of fungi. Molecular Ecology, 22(21), 5271-5277. doi: 10.1111/mec.12481

Kotowska, M. M., Leuschner, C., Triadiati, T., Meriem, S., \& Hertel, D. (2015). Quantifying above- and belowground biomass carbon loss with forest conversion in tropical lowlands of Sumatra (Indonesia). Global Change Biology, 21(10), 3620-3634. doi: 10.1111/gcb.12979

Krasnov, B. R., Mouillot, D., Shenbrot, G. I., Khokhlova, I. S., \& Poulin, R. (2010). Deconstructing spatial patterns in species composition of ectoparasite communities: The relative contribution of host composition, environmental variables and geography. Global Ecology and Biogeography, 19(4), 515-526. doi: 10.1111/j.1466-8238.2010.00529.x

Kurniawan, S., Corre, M. D., Matson, A. L., Schulte-Bisping, H., Utami, S. R., Straaten, O. van, \& Veldkamp, E. (2018). Conversion of tropical forests to smallholder rubber and oil palm plantations impacts nutrient leaching losses and nutrient retention efficiency in highly weathered soils. Biogeosciences, 15(16), 5131-5154. doi: https://doi.org/10.5194/bg-15-5131-2018 
Leff, J. W., Bardgett, R. D., Wilkinson, A., Jackson, B. G., Pritchard, W. J., Long, J. R. D., Oakley, S., Mason, K. E., Ostle, N. J., Johnson, D., Baggs, E. M., \& Fierer, N. (2018). Predicting the structure of soil communities from plant community taxonomy, phylogeny, and traits. The ISME Journal, 12(7), 1794-1805. doi: 10.1038/s41396-018-0089-x

Legendre, P., \& Gallagher, E. D. (2001). Ecologically meaningful transformations for ordination of species data. Oecologia, 129(2), 271-280. doi: 10.1007/s004420100716

Lennon, J. T., \& Jones, S. E. (2011). Microbial seed banks: The ecological and evolutionary implications of dormancy. Nature Reviews Microbiology, 9(2), 119-130. doi: 10.1038/nrmicro2504

Li, Q., Yang, X., Soininen, J., Chu, C.-J., Zhang, J.-Q., Yu, K.-L., \& Wang, G. (2011). Relative importance of spatial processes and environmental factors in shaping alpine meadow communities. Journal of Plant Ecology, 4(4), 249-258. doi: 10.1093/jpe/rtq034

Lichstein, J. W. (2007). Multiple regression on distance matrices: A multivariate spatial analysis tool. Plant Ecology, 188(2), 117-131. doi: 10.1007/s11258-006-9126-3

Malhi, Y., Doughty, C., \& Galbraith, D. (2011). The allocation of ecosystem net primary productivity in tropical forests. Philosophical Transactions of the Royal Society B: Biological Sciences, 366(1582), 3225-3245. doi: 10.1098/rstb.2011.0062

Margono, B. A., Potapov, P. V., Turubanova, S., Stolle, F., \& Hansen, M. C. (2014). Primary forest cover loss in Indonesia over 2000-2012. Nature Climate Change, 4(8), 730-735. doi: 10.1038/nclimate2277

Martin, M. (2014). Cutadapt removes adapter sequences from high-throughpt sequencing reads. EMBnet.Journal, 17(1), 10-12.

McGee, K. M., Eaton, W. D., Shokralla, S., \& Hajibabaei, M. (2018). Determinants of soil bacterial and fungal community composition toward carbon-use efficiency across primary and secondary forests in a Costa Rican conservation area. Microbial Ecology. doi: 10.1007/s00248-018-1206-0

McGuire, K. L., D’Angelo, H., Brearley, F. Q., Gedallovich, S. M., Babar, N., Yang, N., Gillikin, C. M.,Gradoville, R., Bateman, C., Turner, B. L., Mansor, P., Leff, J. W., \& Fierer, N. (2015). Responses of soil fungi to logging and oil palm agriculture in Southeast Asian tropical forests. Microbial Ecology, 69(4), 733-747. doi: 10.1007/s00248-014-0468-4

Mehrabi, Z., \& Tuck, S. L. (2015). Relatedness is a poor predictor of negative plant-soil feedbacks. New Phytologist, 205(3), 1071-1075. doi: 10.1111/nph.13238

Miettinen, J., Shi, C., \& Liew, S. C. (2011). Deforestation rates in insular Southeast Asia between 2000 and 2010. Global Change Biology, 17(7), 2261-2270. doi: 10.1111/j.1365-2486.2011.02398.x

Moll, J., Hoppe, B., König, S., Wubet, T., Buscot, F., \& Krüger, D. (2016). Spatial distribution of fungal communities in an arable soil. PLOS ONE, 11(2), e0148130. doi: 10.1371/journal.pone.0148130

Mueller, R. C., Paula, F. S., Mirza, B. S., Rodrigues, J. L. M., Nuesslein, K., \& Bohannan, B. J. M. (2014). Links between plant and fungal communities across a deforestation chronosequence in the Amazon rainforest. The ISME Journal, 8, 1548-1550.

Mueller, R. C., Rodrigues, J. L. M., Nüsslein, K., \& Bohannan, B. J. M. (2016). Land use change in the Amazon rain forest favours generalist fungi. Functional Ecology, 30(11), 1845-1853. doi: 10.1111/1365-2435.12651

Münzbergová, Z., \& Šurinová, M. (2015). The importance of species phylogenetic relationships and species traits for the intensity of plant-soil feedback. Ecosphere, 6(11), art234. doi: 10.1890/ES15-00206.1

Myers, N., Mittermeier, R. A., Mittermeier, C. G., Da Fonseca, G. A., \& Kent, J. (2000). Biodiversity hotspots for conservation priorities. Nature, 403(6772), 853-858.

Nguyen, N. H., Song, Z., Bates, S. T., Branco, S., Tedersoo, L., Menke, J., Schilling, J. S., \& Kennedy, P. G. (2016). FUNGuild: An open annotation tool for parsing fungal community datasets by ecological guild. Fungal Ecology, 20, 241-248. doi: 10.1016/j.funeco.2015.06.006

Oksanen, J., Blanchet, F. G., Friendly, M., Kindt, R., Legendre, P., McGlinn, D., Minchin, P. R., O'Hara, R. B., Simpson, G. L., Solymos, P., Stevens, M. H. H., Szoecs, E., \& Wagner, H. (2019). vegan: Community Ecology Package version 2.5-6.

Orwin, K. H., Kirschbaum, M. U. F., John, M. G. S., \& Dickie, I. A. (2011). Organic nutrient uptake by mycorrhizal fungi enhances ecosystem carbon storage: A model-based assessment. Ecology Letters, 14(5), 493502. doi: 10.1111/j.1461-0248.2011.01611.x 
Paoletti, A., Darras, K., Jayanto, H., Grass, I., Kusrini, M., \& Tscharntke, T. (2018). Amphibian and reptile communities of upland and riparian sites across Indonesian oil palm, rubber and forest. Global Ecology and Conservation, 16, e00492. doi: 10.1016/j.gecco.2018.e00492

Peay, K. G., Baraloto, C., \& Fine, P. V. (2013). Strong coupling of plant and fungal community structure across western Amazonian rainforests. The ISME Journal, 7(9), 1852-1861. doi: 10.1038/ismej.2013.66

Peay, K. G., Russo, S. E., McGuire, K. L., Lim, Z., Chan, J. P., Tan, S., \& Davies, S. J. (2015). Lack of host specificity leads to independent assortment of dipterocarps and ectomycorrhizal fungi across a soil fertility gradient. Ecology Letters, 18(8), 807-816. doi: 10.1111/ele.12459

Philippot, L., Raaijmakers, J. M., Lemanceau, P., \& van der Putten, W. H. (2013). Going back to the roots: The microbial ecology of the rhizosphere. Nature Reviews Microbiology, 11(11), 789-799. doi: 10.1038/nrmicro3109

Powell, J. R., Karunaratne, S., Campbell, C. D., Yao, H., Robinson, L., \& Singh, B. K. (2015). Deterministic processes vary during community assembly for ecologically dissimilar taxa. Nature Communications, 6 , 8444. doi: $10.1038 /$ ncomms9444

Prescott, C. E., \& Grayston, S. J. (2013). Tree species influence on microbial communities in litter and soil: Current knowledge and research needs. Forest Ecology and Management, 309, 19-27. doi: 10.1016/j.foreco.2013.02.034

$\mathrm{R}$ Core Team. (2019). R: A language and environment for statistical computing. R Foundation for Statistical Computing, Vienna, Austria.

Rembold, K., Mangopo, H., Tjitrosoedirdjo, S. S., \& Kreft, H. (2017). Plant diversity, forest dependency, and alien plant invasions in tropical agricultural landscapes. Biological Conservation, 213, 234-242. doi: 10.1016/j.biocon.2017.07.020

Rillig, M. C. (2004). Arbuscular mycorrhizae and terrestrial ecosystem processes. Ecology Letters, 7(8), 740-754. doi: 10.1111/j.1461-0248.2004.00620.x

Rodríguez-Echeverría, S., Teixeira, H., Correia, M., Timóteo, S., Heleno, R., Öpik, M., \& Moora, M. (2017). Arbuscular mycorrhizal fungi communities from tropical Africa reveal strong ecological structure. New Phytologist, 213(1), 380-390. doi: 10.1111/nph.14122

Rognes, T., Flouri, T., Nichols, B., Quince, C., \& Mahé, F. (2016). VSEARCH: A versatile open source tool for metagenomics. PeerJ, 4, e2584. doi: 10.7717/peerj.2584

Rosindell, J., Hubbell, S. P., \& Etienne, R. S. (2011). The unified neutral theory of biodiversity and biogeography at age ten. Trends in Ecology \& Evolution, 26(7), 340-348. doi: 10.1016/j.tree.2011.03.024

Sahner, J., Budi, S. W., Barus, H., Edy, N., Meyer, M., Corre, M. D., \& Polle, A. (2015). Degradation of root community traits as indicator for transformation of tropical lowland rain forests into oil palm and rubber plantations. PLOS ONE, 10(9), e0138077. doi: 10.1371/journal.pone.0138077

Schappe, T., Albornoz, F. E., Turner, B. L., Neat, A., Condit, R., \& Jones, F. A. (2017). The role of soil chemistry and plant neighbourhoods in structuring fungal communities in three Panamanian rainforests. Journal of Ecology, 105(3), 569-579. doi: 10.1111/1365-2745.12752

Schneider, D., Engelhaupt, M., Allen, K., Kurniawan, S., Krashevska, V., Heinemann, M., Nacke, H., Wijayanti, M., Meryandini, A., Corre, M. D., Scheu, S., \& Daniel, R. (2015). Impact of lowland rainforest transformation on diversity and composition of soil prokaryotic communities in Sumatra (Indonesia). Frontiers in Microbiology, 6. doi: 10.3389/fmicb.2015.01339

Schröter, K., Wemheuer, B., Pena, R., Schöning, I., Ehbrecht, M., Schall, P., Ammer, C., Daniel, R., \& Polle, A. (2019). Assembly processes of trophic guilds in the root mycobiome of temperate forests. Molecular Ecology, 28(2), 348-364. doi: 10.1111/mec.14887

Six, J., Frey, S. D., Thiet, R. K., \& Batten, K. M. (2006). Bacterial and fungal contributions to carbon sequestration in agroecosystems. Soil Science Society of America Journal, 70(2), 555. doi: 10.2136/sssaj2004.0347

Smith, S. E., Jakobsen, I., Grønlund, M., \& Smith, F. A. (2011). Roles of arbuscular mycorrhizas in plant phosphorus nutrition: Interactions between pathways of phosphorus uptake in arbuscular mycorrhizal roots have important implications for understanding and manipulating plant phosphorus acquisition. Plant Physiology, 156(3), 1050-1057. doi: 10.1104/pp.111.174581

Stibig, H.-J., Achard, F., Carboni, S., Raši, R., \& Miettinen, J. (2014). Change in tropical forest cover of Southeast Asia from 1990 to 2010. Biogeosciences, 11(2), 247-258. doi: 10.5194/bg-11-247-2014 
Tedersoo L., Bahram, M., , Põlme, S., Kõljalg, U., Yorou, N. S., Wijesundera, R., Ruiz, L. V., Vasco-Palacios, A. M., Thu, P. Q., Suija, A., Smith M. E., Sharp, C., Saluveer, E., Saitta A., Rosas, M., Riit, T., Ratkowsky, D., Pritsch, K., Põldmaa, K., Piepenbring, M., Phosri, C., Peterson, M., Parts, K., Pärtel, K., Otsing, E., Nouhra, E., Njouonkou, A. L, Nilsson, R. H., Morgado, L. N., Mayor, J., May T. W., Majuakim, L., Lodge D. J., Lee, S. S., Larsson K.-H., Kohout, P., Hosaka, K., Hiiesalu I., Henkel, T. W., Harend, H., Guo, L., Greslebin, A., Grelet G., Geml, J., Gates, G., Dunstan, W., Dunk, C., Drenkhan, R., Dearnaley, J., de Kesel, A., Dang T., Chen, X., Buegger F., Brearley, F. Q., Bonito, G., Anslan S., Abell S., Abarenkov K. (2014). Global diversity and geography of soil fungi. Science, 346(6213), 1256688-1256688. doi: 10.1126/science.1256688

Toju, H., Tanabe, A. S., Yamamoto, S., \& Sato, H. (2012). High-coverage ITS primers for the DNA-based identification of Ascomycetes and Basidiomycetes in environmental samples. PLoS ONE, 7(7), e40863. doi: 10.1371/journal.pone.0040863

Treseder, K. K., \& Lennon, J. T. (2015). Fungal traits that drive ecosystem dynamics on land. Microbiology and Molecular Biology Reviews, 79(2), 243-262. doi: 10.1128/MMBR.00001-15

Tuomisto, H., Ruokolainen, L., \& Ruokolainen, K. (2012). Modelling niche and neutral dynamics: On the ecological interpretation of variation partitioning results. Ecography, 35(11), 961-971. doi: 10.1111/j.1600-0587.2012.07339.x

Turner, B. L., Brenes-Arguedas, T., \& Condit, R. (2018). Pervasive phosphorus limitation of tree species but not communities in tropical forests. Nature, 555(7696), 367-370. doi: 10.1038/nature25789

Urbina, H., Breed, M. F., Zhao, W., Lakshmi Gurrala, K., Andersson, S. G. E., Ågren, J., Baldauf, S., \& Rosling, A. (2018). Specificity in Arabidopsis thaliana recruitment of root fungal communities from soil and rhizosphere. Fungal Biology, 122(4), 231-240. doi: 10.1016/j.funbio.2017.12.013

van der Heijden, M. G. A., Dombrowski, N., \& Schlaeppi, K. (2017). Continuum of root-fungal symbioses for plant nutrition. Proceedings of the National Academy of Sciences, 114(44), 11574-11576. doi: 10.1073/pnas.1716329114

van der Heijden, M. G. A., Martin, F. M., Selosse, M.-A., \& Sanders, I. R. (2015). Mycorrhizal ecology and evolution: The past, the present, and the future. New Phytologist, 205(4), 1406-1423. doi: 10.1111/nph.13288

van der Linde, S., Suz, L. M., Orme, C. D. L., Cox, F., Andreae, H., Asi, E., Atkinson, B., Benham, S., Carroll, C., Cools, N., de Vos, B., Dietrich, H.-P., Eichhorn, J., Gehrmann, J., Grebenc, T., Gweon, H. S., Hansen, K., Jacob, F., Kristöfel, F., Lech, P., Manninger, M., Martin, J., Meesenburg, H., Merilä, P., Nicolas, M., Pavlenda, P., Rautio, P., Schaub, M., Schröck, H.-W., Šrámek, V., Thimonier, A., Thomsen, I. M., Titeux, H., Vanguelova, E., Verstraeten, A., Vesterdal, L., Waldner, P., Wijk, S., Zhang, Y., Žlindra, D., \& Bidartondo, M. I. (2018). Environment and host as large-scale controls of ectomycorrhizal fungi. Nature, 558(7709), 243-248. doi: 10.1038/s41586-018-0189-9

Welch, B. L. (1947). The generalization of 'Student's' problem when several different population variances are involved. Biometrika, 34(1/2), 28-35.

Wetzel, C. E., Bicudo, D. de C., Ector, L., Lobo, E. A., Soininen, J., Landeiro, V. L., \& Bini, L. M. (2012). Distance decay of similarity in Neotropical diatom communities. PLOS ONE, 7(9), e45071. doi: 10.1371/journal.pone.0045071

White, T. J., Bruns, T., Lee, S., \& Taylor, J. (1990). Amplification and direct sequencing of fungal ribosomal RNA genes for phylogenetics. In M. A. Innis, D. H. Gelfand, J. J. Sninsky, \& T. J. White (Eds.), PCR protocols: A guide to methods and applications (pp. 315-322). Cambridge, USA: Academic Press

Wilcove, D. S., \& Koh, L. P. (2010). Addressing the threats to biodiversity from oil-palm agriculture. Biodiversity and Conservation, 19(4), 999-1007. doi: 10.1007/s10531-009-9760-x

Wilschut, R. A., Putten, W. H. van der, Garbeva, P., Harkes, P., Konings, W., Kulkarni, P., Martens, H., \& Geisen, S. (2019). Root traits and belowground herbivores relate to plant-soil feedback variation among congeners. Nature Communications, 10(1), 1-9. doi: 10.1038/s41467-019-09615-x

Yang, T., Tedersoo, L., Soltis, P. S., Soltis, D. E., Gilbert, J. A., Sun, M., Shi, Y., Wang, H., Li, Y., Zhang, J., Chen, Z., Lin, H., Zhao, Y., Fu, C., \& Chu, H. (2019). Phylogenetic imprint of woody plants on the soil mycobiome in natural mountain forests of eastern China. The ISME Journal, 13(3), 686-697. doi: 10.1038/s41396018-0303-x

Zhang, J., Kobert, K., Flouri, T., \& Stamatakis, A. (2014). PEAR: A fast and accurate Illumina paired-end read merger. Bioinformatics, 30(5), 614-620. doi: 10.1093/bioinformatics/btt593 
Zhao, J., Gao, Q., Zhou, J., Wang, M., Liang, Y., Sun, B., Chu, H., \& Yang, Y. (2019). The scale dependence of fungal community distribution in paddy soil driven by stochastic and deterministic processes. Fungal Ecology, 42, 100856. doi: 10.1016/j.funeco.2019.07.010

Zheng, Y., Hu, H.-W., Guo, L.-D., Anderson, I. C., \& Powell, J. R. (2017). Dryland forest management alters fungal community composition and decouples assembly of root- and soil-associated fungal communities. Soil Biology and Biochemistry, 109, 14-22. doi: 10.1016/j.soilbio.2017.01.024

Zinger, L., Taberlet, P., Schimann, H., Bonin, A., Boyer, F., Barba, M. D., Gaucher, P., Gielly, L., Giguet-Covex, C., Iribar, A., Réjou-Méchain, M., Rayé, G., Rioux, D., Schilling, V., Tymen, B., Viers, J., Zouiten, C., Thiller, W., Coissac, E., \& Chave, J. (2019). Body size determines soil community assembly in a tropical forest. Molecular Ecology, 28(3), 528-543. doi: 10.1111/mec.14919 


\section{Declaration}

This chapter has been submitted for publication with the following authors:

Johannes Ballauff (Forest Botany and Tree Physiology, University of Goettingen, Germany); Dominik Schneider (Genomic and Applied Microbiology and Göttingen Genomics Laboratory, University of Goettingen, Germany); Nur Edy (Department of Agrotechnology, University of Tadulako, Indonesia); Bambang Irawan (Faculty of Forestry, University of Jambi, Indonesia); Rolf Daniel (Genomic and Applied Microbiology and Göttingen Genomics Laboratory, University of Goettingen, Germany); Andrea Polle (Forest Botany and Tree Physiology, University of Goettingen, Germany)

J. B. conducted the research, data analysis, and wrote the first manuscript; D. S. conducted the bioinformatic processing of the sequencing data; N. E. and B.I. provided support with the field work and export of samples; R. D. supervised and contributed to the molecular fungal community analysis; A. P. conceived the project and contributed to writing of the final manuscript; all authors contributed to the final manuscript via comments and revisions.

\section{Data Accessibility}

Fungal OTU sequences were deposited in the National Center for Biotechnology Information (NCBI) Sequence Read Archive (SRA) under the accession number of Bioproject: PRJNA616036. 


\section{Supplementary Information}

Supplementary Table S 2.2.1 Landscape, land-use type and coordinates of all research plots as well as all measured soil chemical properties and root community traits. $\mathrm{RI}=$ Resource Index (sum of standardized calcium, magnesium, potassium, iron and manganese concentrations), PC = principle component axis scores from the principle component analysis used to measure soil and root trait indices

See digital supplement supp/Table_S221.xIxs

Supplementary Table S 2.2.2 Read counts of all fungal operational taxonomic units (OTU; clustered at $97 \%$ similarity threshold) in soil and root samples of each plot (columns $1-89$ ) as well as taxonomic (columns $90-92$ ) and functional (column $93-98$ ) affiliations; $H$ = harapan landscape; $B$ = bukit landscape; $\mathrm{F}=$ forest; $\mathrm{J}=$ jungle rubber; $\mathrm{R}=$ rubber plantation; $\mathrm{O}=$ oil palm plantation; $\mathrm{C}=$ upland site; $r$ = riparian site

See digital supplement supp/Table_S222.xIxs

Supplementary Table S 2.2.3 Mean fungal OTU richness of soil fungal community (SFC) and root associated fungal communities (RFC) for different land-use systems, landscapes (Bukit, Harapan) and drained uplandas well as riparian sites. Letters denote differences between land-use systems according to pair wise comparisons with Tukey Test; SD = standart devaition

\begin{tabular}{llcc}
\hline Landscape & Land-use system & SFC & RFC \\
& & Mean OTU richness $( \pm$ SD $)$ & Mean OTU richness $( \pm$ SD $)$ \\
\hline Bukit & Forest & $2122( \pm 164)$ ab & $791( \pm 106)$ ab \\
& Jungle Rubber & $2318( \pm 103) \mathbf{b}$ & $869( \pm 84)$ b \\
& Rubber & $1901( \pm 128)$ a & $658( \pm 45)$ a \\
& Oil palm & $1909( \pm 160)$ a & $710( \pm 87)$ ab \\
Harapan & Forest & $2363( \pm 131)$ a & $1146( \pm 149)$ b \\
upland sites & Jungle Rubber & $2300( \pm 223)$ a & $880( \pm 56)$ a \\
& Rubber & $2204( \pm 161)$ a & $970( \pm 82)$ ab \\
& Oil Palm & $2074( \pm 134)$ a & $865( \pm 84)$ a \\
Harapan & Forest & $2014( \pm 348)$ a & $950( \pm 108)$ b \\
riparian sites & Rubber & $1994( \pm 172)$ a & $804( \pm 63)$ ab \\
& Oil Palm & $1838( \pm 228)$ a & $700( \pm 78)$ a \\
\hline
\end{tabular}




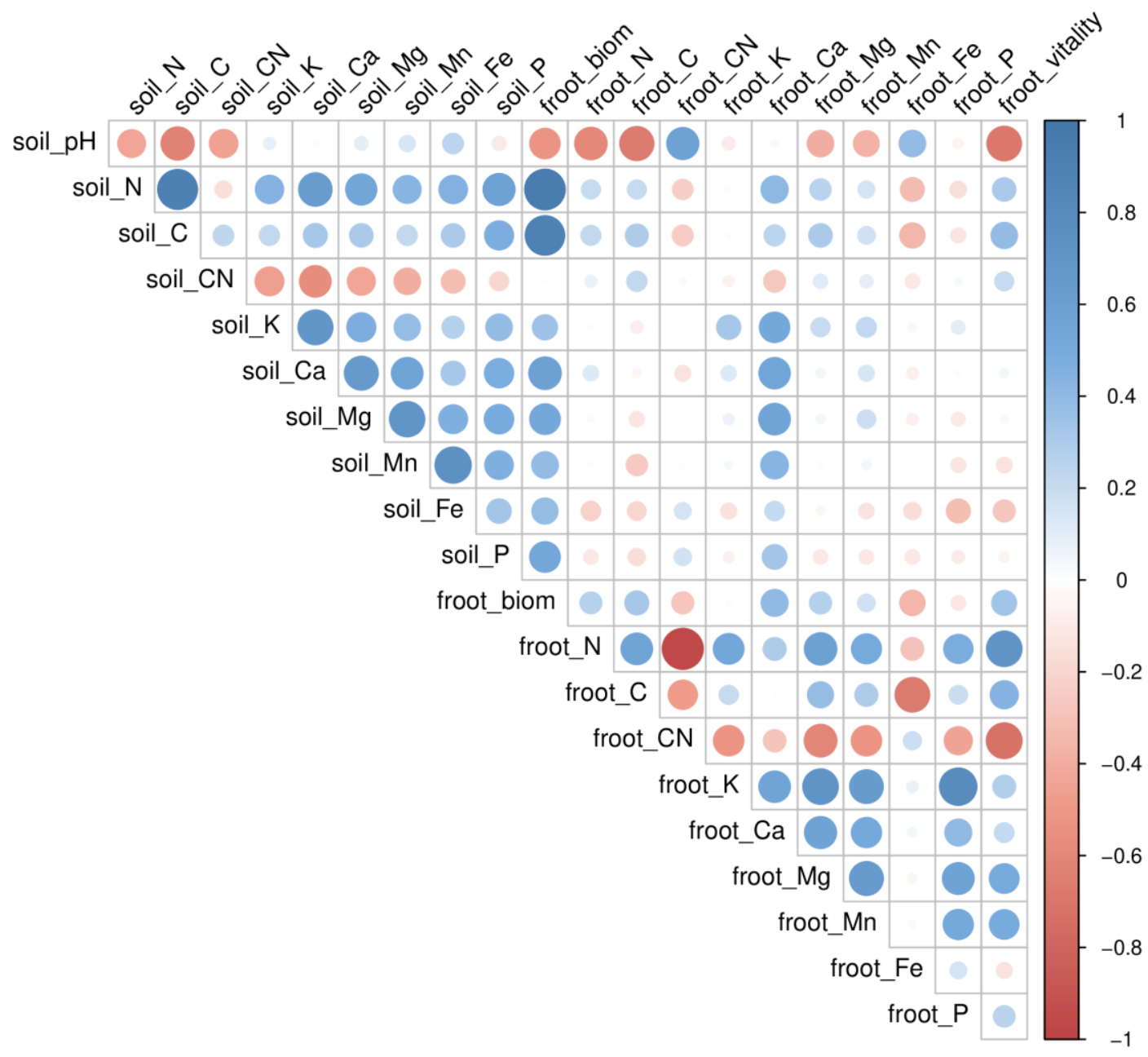

Supplementary Figure S 2.2.1 Pearson correlations coefficients between all environmental variables. Root biomass and soil nitrogen were strongly correlated with soil carbon $(r>0.8)$ and excluded from the analysis to avoid multicollinearity. $N=$ total nitrogen concentration [mg g-1], $C=$ total carbon concentration [mg g-1], $\mathrm{CN}=$ carbon to nitrogen ratio, $\mathrm{K}=$ potassium concentration [mg g-1], $\mathrm{Ca}=$ calcium concentration [mg g-1], $\mathrm{Mg}=$ magnesium concentration $[\mathrm{mg} \mathrm{g}-1], \mathrm{Mn}=$ manganese concentration [mg g-1], $\mathrm{Fe}=$ iron concentration [mg g-1], $\mathrm{P}=$ phosphorus concentration [mg g-1], froot $=$ fine roots (<= $2 \mathrm{~mm}$ diameter), biom = dry weight biomass [g $\mathrm{m}-2$ ], vitality [\% vital fine root tips] 


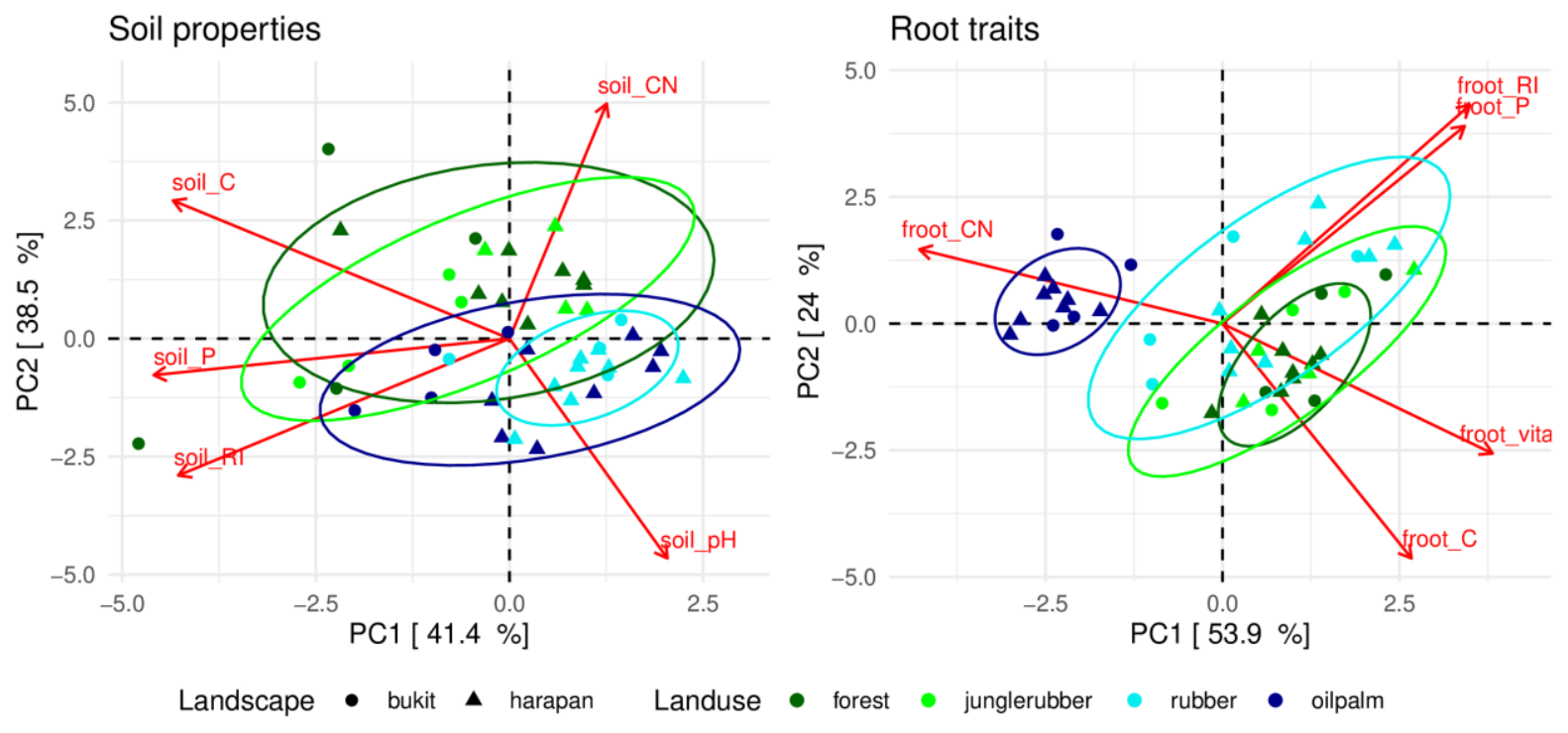

Supplementary Figure S 2.2.2 Principle component analysis (PC) for spoil and root chemical variables. Scores for all plots are shown. First two PCs were used as unifying measure for soil properties and root traits. $C=$ total carbon concentration [mg g-1], $\mathrm{CN}=$ carbon to nitrogen ratio, $P$ = phosphorus concentration [mg g-1], RI = Cation Resource Index (sum of standardized calcium, magnesium, potassium, iron and manganese concentrations $)$, froot $=$ fine roots $\quad<=2 \mathrm{~mm}$ diameter), vita = vitality [\% vital fine root tips] 

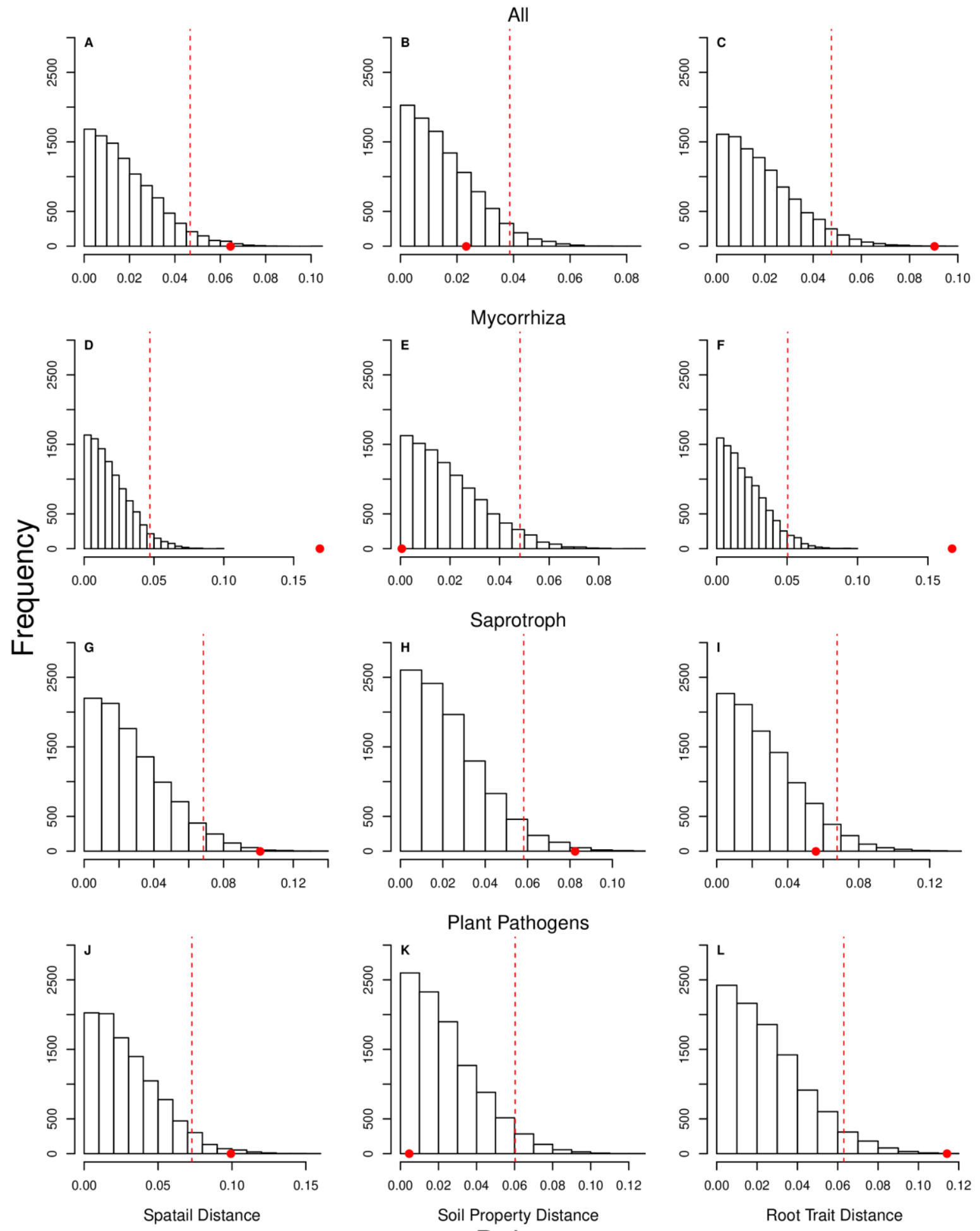

Delta $r$

Supplementary Figure S 2.2.3 Null model distribution of the absolute difference between correlation coefficients of soil and root associated communities with spatial, soil property and root trait distance. Random permutation with $\mathbf{1 0 0 0 0}$ iterations was applied. After each step community matrices were permuted while corresponding environmental and geographical distance was kept constant. The correlation coefficient was calculated for both permuted communities to estimate the absolute difference. Red dot mark the originally observed value and dashed line denotes the upper $5 \%$ quantile. Null models were calculated for the full fungal community as well as mycorrhiza, saprotrophs and plant pathogens only. 


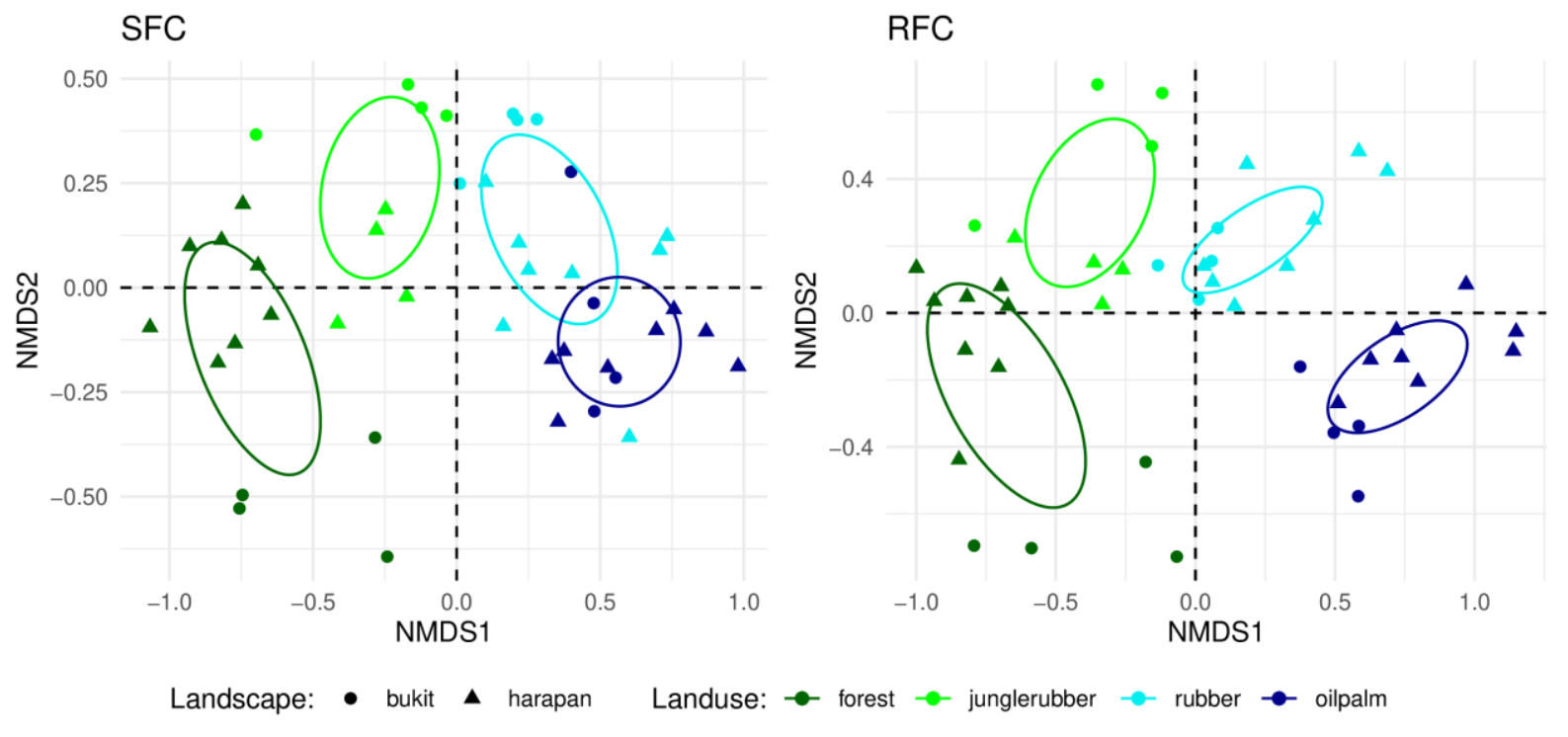

Supplementary Figure S 2.2.4 Non-metric multidimensional scaling (NMDS) soil fungal community (SFC) and root associated fungal community (RFC) dissimilarity (Bray-Curtis). Ellipses denote standard errors from the centroid of each land-use system. 


\subsection{Soil conditions and stochasticity, not tree diversity drive the soil fungal community in a newly-established biodiversity enriched oil palm plantation}

\section{Introduction}

There is a world-wide increasing demand for vegetable oil and oil palm has a superior yield potential compared to any alternative crops (Carrasco, Larrosa, Milner-Gulland, \& Edwards, 2014; Sayer, Ghazoul, Nelson, \& Klintuni Boedhihartono, 2012). Especially in Indonesia, the world's biggest exporters of palm oil, this industry has lead to a tremendous economic uprising (Euler, Krishna, Schwarze, Siregar, \& Qaim, 2017; Euler, Schwarze, Siregar, \& Qaim, 2016; Kubitza, Krishna, Alamsyah, \& Qaim, 2018). Oil palm cultivation provides strong improvement of the financial status, social situation and labor conditions for a significant proportion of the country's population (Euler, Krishna, Schwarze, Siregar, \& Qaim, 2017; Kubitza, Krishna, Alamsyah, \& Qaim, 2018). On the downside of these positive effects, the conversion of hyper diverse tropical rain forest to profitable oil palm plantations is one of the major drivers for forest cover loss in South East Asia in the last decades (Wilcove and Koh 2010; Gibbs et al. 2010; Miettinen et al. 2011; Abood et al. 2015; Vijay et al. 2016). The heavily managed oil palm monocultures only harbor a small proportion of the natural occurring biodiversity (Drescher et al., 2016; Fitzherbert et al., 2008; Obidzinski, Andriani, Komarudin, \& Andrianto, 2012; Rembold, Mangopo, Tjitrosoedirdjo, \& Kreft, 2017). A wide range of ecosystem services are massively impaired (Barnes et al., 2017; Dislich et al., 2017; Grass et al. 2020). It is therefore crucial, not only to call for strict protection of remaining low-land forest, but also to find alternative management strategies suitable to maintain high productivity while at the same time sustain larger proportions of local biodiversity and ecosystem functions (Koh et al. 2009; Foster et al. 2011). Agroforestry systems with intermixed tree and crop species are a promising approach to find a balance between economical productivity and sustainable management by promoting biodiversity (Bhagwat, Willis, Birks, \& Whittaker, 2008; Schroth et al., 2004; Tscharntke et al., 2011) and ecosystem functions of tropical systems (de Carvalho, Vasconcelos, Kato, Capela, \& Castellani, 2014; Ramos, Vasconcelos, Kato, \& Castellani, 2018).

Soil-borne fungi are a key component of all terrestrial ecosystems facilitating nutrient flow and massively contributing to soil health (Frąc, Hannula, Bełka, \& Jędryczka, 2018; Rillig, 2004; van der Heijden, Bardgett, \& van Straalen, 2008). Diversity and composition of those communities are driven by abiotic soil variables, especially $\mathrm{pH}$ and soil nutrients (Barnes, Maldonado, Frøslev, Antonelli \& 
Rønsted, 2016; Glassman, Wang \& Bruns, 2017; Rodríguez-Echeverría et al., 2017; Tedersoo, Bahram, \& Dickie, 2014; cf. Chapter 2.2). However, the plant and belowground fungal communities form numerous interactions and are thus, strongly depend on each other (Philippot, Raaijmakers, Lemanceau, \& van der Putten, 2013; Smith, Jakobsen, Grønlund, \& Smith, 2011; van der Heijden, Dombrowski, \& Schlaeppi, 2017). Thus, changes in edaphic properties as well as plant community can alter the fungal communities across tropical agroforestry systems (Buyer, Baligar, He, \& ArévaloGardini, 2017; Zhang et al., 2019). Transformation of forests to oil palm plantations strongly alters the soil fungal community (Kerfahi, Tripathi, Lee, Edwards, \& Adams, 2014; McGuire et al., 2015; Brinkmann et al. 2019), negatively affecting abundance of mycorrhizas while promoting plant pathogenic fungi (Brinkmann et al., 2019, cf. chapter 2.1). Management strategies counteracting those shifts may promote overall soil functions and contribute to ecosystem restoration (Kardol \& Wardle, 2010). Enrichment planting of native multipurpose tree species is an innovative approach to recover functions and diversity in a conventionally managed oil palm plantation while maintaining high productivity (Teuscher et al., 2016). So far the effect of tree enrichment on the soil fungal community has not been studied.

In a novel experimental approach, following suggestions by Corbin \& Holl (2012), native multipurpose tree species were planted within "tree diversity islands" across a large-scale commercial oil palm plantation promote the local diversity. Within the tree islands oil palm density was reduced and varying numbers and combinations of tree species were planted. No further management was applied after tree establishment to allow for natural plant undergrowth succession (Teuscher et al., 2016). First results, after two years of enrichment planting, show elevated yields of palm trees within and adjacand to the island compensating for reduced oil palm density (Gérard et al., 2017) as well as improved tree performance (Zemp, Gérard, et al., 2019) and stand structural complexity (Zemp, Ehbrecht, et al., 2019) associated with tree diversity. Here, we used this enrichment experiment to study soil fungal communities by next generation sequencing across all diversity islands as well as reference plantation plots after three years of tree planting. We measured soil $\mathrm{pH}$, carbon, nitrogen and available phosphorous concentration to control for their structuring effect on the fungal community. We tested the effects of tree diversity, presence of individual tree species and edaphic conditions on the soil fungal community composition, to test the following hypothesis: (i) Tree diversity enrichment and natural plant succession alter soil fungal communities and promote the abundance of plant beneficial mycorrhizal fungi. (ii) Effects of tree enrichment will be strongest in larger tree islands due to reduced edge effect. (iii) Individual tree host species contribute differently to the taxonomic and functional composition of the soil fungal community. 


\section{Material and Methods}

\section{Research site and experimental design}

This study was conducted in the frame work of the biodiversity enrichment experiment of the Collaborative Research Center 990 (Teuscher et al., 2016; Zemp, Gérard, et al., 2019). The research site is located in the mid-sized oil palm plantation PT Humusindo Makmur Sejati (01.95_S and 103.25 E, $47 \pm 11 \mathrm{~m}$ a.s.l.), Jambi Province, Sumatra (Indonesia) with a humid tropical climate (mean temperature $26.7 \pm 1.0{ }^{\circ} \mathrm{C}$, annual precipitation $2235 \pm 285 \mathrm{~mm}$ ) (Drescher et al., 2016) on loamy Acrisol (Allen, Corre, Tjoa, \& Veldkamp, 2015). Dipterocarp dominated low-land rainforests were the primary natural vegetation before transformation (Miettinen et al. 2011). The plantation was established between 2001 and 2007. The oil palms were planted in a $9 \mathrm{~m} \times 9 \mathrm{~m}$ triangular grid (ca. 143 palms per hectar). Conventional management comprises the application of $230 \mathrm{~kg} \mathrm{~N}$ (Urea), 196 kg P (Triple Superphosphate, rock phosphate), $142 \mathrm{~kg} \mathrm{~K} \mathrm{(KCl),} 54$ kg Mg (Kiserite, Dolomite), $0.79 \mathrm{~kg} \mathrm{~B}$ (Borax) all in ha ${ }^{-1}$ and year ${ }^{-1}$ as well as occasional addition of $\mathrm{S}\left(\left(\mathrm{NH}_{4}\right)_{2} \mathrm{SO}_{4}\right)$, Si (Zeolite) and Ca (Teuscher et al., 2016). Furthermore, regular manual weeding of epiphytes and understory was applied (Teuscher et al., 2016). In the plantation, 56 tree diversity islands with varying size and tree diversity were established in 2013. For a detailed description of the experimental design as well as plantation management practices see Teuscher et al. (2016). In short, tree diversity islands comprise six native multi-purpose tree species (Parkia speciosa, Archidendron pauciflorum, Durio zibethinus, Peronema canescens, Shorea leprosula, Dyera polyphylla) assembled in one of five diversity levels $(0,1,2,3$ and 6 species per island) and with a size of $5 \mathrm{~m} \times 5 \mathrm{~m}, 10 \mathrm{~m} \times 10 \mathrm{~m}, 20 \mathrm{~m} \times 20 \mathrm{~m}$ and $40 \mathrm{~m} \times$ $40 \mathrm{~m}$. All tree compositions were drawn at random with the restriction, that no repetition across plots is allowed and each species is selected exactly once at each diversity level. Islands were distributed randomly on the plantation with a minimum distance of $85 \mathrm{~m}$ between them. Approximately $40 \%$ of the oil palms were removed in the island areas and trees were planted in a 2 $\mathrm{m}$ grid according to diversity level and composition. Newly planted trees were initially fertilized to promote growth (inorganic: 19 kg N, 8 kg P, 6 kg Mg; organic: 11 kg N, 7 kg P, 10 kg K, 4 kg Mg, 20 kg $\mathrm{Ca}$; all in ha ${ }^{-1}$ ), and mechanical weeding around the base was conducted during the initial phase to prevent overgrowth by understory vegetation. However, after several months management of the Islands was stopped entirely to allow for natural succession. Four additional plots with management as usual (no removal of oil palm, usual fertilization, weeding and harvesting) were included in the study as reference summing to a total of 56 research plots. Diversity levels and size of all tree islands as well as planted tree species combination can be found in Supplementary Table S 2.3.1. 


\section{Sampling}

Sampling was conducted in December 2016, at the beginning of the regional rainy season. In each diversity island and the 4 reference plots three soil cores (10 cm depth, $4 \mathrm{~cm}$ diameter) were extracted from a $5 \times 5 \mathrm{~m}$ area regardless of diversity Island size to avoid effects of spatial distance. The minimum distance to the edge in all islands, larger than $5 \mathrm{~m} \times 5 \mathrm{~m}$, was $2 \mathrm{~m}$. Samples were sieved (50 $50 \mathrm{~mm}$ mesh) roots and larger litter was removed. Samping resulted in a total of 168 soil cores (three replicates in each of: 4 reference plots, 4 islands with only reduced oil plam density, 24 islands with one additional tree species, 24 islands with multiple additional tree species). Aliquots of oil samples were immediately freeze dried (VirTis Bench Top K, SP Industries, Warminster, USA) and exported to University of Göttingen (Germany).

\section{Soil nutrient elements and $\mathrm{pH}$}

Dry soil samples were ground for one minute in a ball-mill (MM 2000, Retsch, Haan, Germany). Soil samples were weighed into tin cartouches and used to determine total carbon (C) and nitrogen (N) by the combustion method in a CN analyzer (Vario MICRO analyzer, Elementar, Langensbold, Germany). Plant available phosphorous (P) was extracted following the method by Bray and Kurtz (1945). Soil (100 mg) was mixed with $15 \mathrm{ml}$ of Bray-I Extraction Solution (0.03 N NH${ }_{4} \mathrm{~F}$ and $0.025 \mathrm{~N}$ $\mathrm{HCl}$ ). The suspension was placed on a shaker for 60 minutes and subsequently filtered through phosphate free filters (MN 280 1/4 125 mm, Macherey - Nagel, Düren, Germany). Phosphate concentration of the filtrates was measured by inductively coupled plasma mass spectrometry (iCap 7000, Thermo Fisher Scientific, Waltham, USA). Soil pH was measured in a $0.1 \mathrm{M} \mathrm{KCl}$ suspension according to ISO 10390 standard. The pH analysis was conducted in the Department of soil Sciences of Temperate Ecosystems, Georg-August-University (Goettingen, Germany).

\section{Fungal community}

Freeze dried soil samples were used for DNA extraction. The fungal community was analyzed based on the internal transcript spacer region 2 (ITS2). The marker was amplified by polymerase chain reaction (PCR) using ITS3_KYO1 (Toju, Tanabe, Yamamoto, \& Sato, 2012) and ITS4 (White, Bruns, Lee, \& Taylor, 1990). The protocol followed the steps in detail presented in the methods section of chapter 2.2. Amplicon sequencing was conducted at the Göttingen Genomics Laboratory with the MiSeq Reagent Kit v3 (Illumina Inc., San Diego, USA) for next generation sequencing. Subsequnt processing of the raw paired-end reads, assembly of the OTU community matrix as well as taxonomic annotation followed the procedure described in the methods section of chapter 2.2. Fungal OTUs were assigned to trophic guilds according to their taxonomy, based on the FunGuild database (Nguyen et al., 2016; Supplementary Table S 2.3.2). 


\section{Statistical analysis}

Statistical analyses were performed using R v.3.6.1 (R Core Team 2019). Mean values of $C, N$ and $P$ measurements from the three samples per island were used for subsequent analysis Supplementary Table S 2.3.1). Carbon and nitrogen content were highly correlated $(r>0.9)$. Therefore, the $C$ to $N$ ratio was calculated (Supplementary Table S 2.3.1) and included as explanatory variable, while total carbon was excluded from further analysis to avoid multicollinearity.

The number of fungal OTU reads in each sample was rarefied to the minimum read count of 18000 using the rrarefy() function of the package vegan v2.5.6 (Oksanen et al. 2019). Subsequently, counts of the three samples per island were added to obtain the island community (Supplementary Table $S$ 2.3.2). The effect of tree enrichment on the fungal OTU richness was compared with control plantation plots by analysis of variance (ANOVA). A multivariate linear model was used to test the effect of tree species richness (0 to 6 planted tree species) on OTU richness. Simple regression models were used to test the effect of soil variables $(\mathrm{pH}, \mathrm{N}, \mathrm{CN}, \mathrm{P})$ on OTU richness. Further, a multivariate linear regression model, including tree species richness, tree island size and soil variables, was constructed and the importance of the explanatory variables was assessed by stepwise backwards model selection. The model with the smallest Akaike Information Criterion (AIC) was selected. The $\mathrm{pH}$ gradient across plots was relatively small (3.75 to 4.56 units) but in four plots extreme outliers (range: 5.14 to $6.32,>3 x$ Inter Quartile Range) strongly determining the model parameters were present. Thus, models were recalculated excluding those plots. Exclusion increased p-values of simple regression models but did not change overall observed trends.

Effect of tree richness on the community composition of fungal taxa (order level) and trophic groups (saprotroph, pathotroph, symbiotroph) were tested using Analysis of Similarity (ANOSIM) as implemented in the anosim() function of the vegan package. To estimate $p$-values, 999 permutations were calculated. To analyze the potential effect of tree identitys on the fungal community composition, a subset of the community data only containing the tree islands with a single additional tree species was created. The community composition (relative abundances of fungal orders) was compared among islands containing only a single of the planted tree species ( $P$. speciosa, $A$. pauciflorum, D. zibethinus, P. canescens, S. leprosula, D. polyphylla) or no additional tree species using the $\operatorname{anosim()~function~wit~} 999$ permutations. The OTU community matrix was Hellinger transformed to lower the weight of low count OTUs (Legendre \& Gallagher, 2001) using the function decostand() of the vegan package. The effect of tree diversity on the fungal OTU community composition was tested using the anosim() function with 999 permutations. To further analyze the community composition, non-metric multidimensional scaling (NMDS) was applied using the function metaMDS() of the vegan package. Structuring effects of tree diversity level, tree species and island 
size, as well as soil abiotic variables (excluding extreme $\mathrm{pH}$ values) were tested using the envfit() function. Further, structuring effects were tested using Distance-based Redundancy Analysis (dbRDA) as implemented in the capscale() function. A full model containing tree diversity, tree species, island size and soil variables was constructed. Backwards stepwise model selection using the function ordistep() was performed to obtain the model with lowest AIC value. Significance of the overall model as well as marginal effects of environmental variables were tested using permutation tests as implemented in vegans' anova.cca() function with 999 permutations. 


\section{Results}

We obtained a total number of 8283 OTUs in the rarefied OTU community data (total number sequence counts: 3.1 million) with a mean species richness of $1501( \pm 220)$ per tree island. Fungal richness in tree islands did not differ from the control plantation sites regardless of tree diversity level $\left(F_{5,50}=0.950, p=0.457\right)$ or island size $\left(F_{1,54}=0.127, p=0.723\right)$ and there was no relation between OTU richness and tree species richness $\left(F_{1,50}=0.286, p=0.595\right.$, Figure 2.3.1). Edaphic conditions between tree islands were relatively homogenous and only marginally significant positive relationships between soil $\mathrm{pH}\left(\mathrm{F}_{1,50}=3.494, \mathrm{p}=0.067\right)$, soil nitrogen $\left(F_{1,50}=3.687, \mathrm{p}=0.061\right)$ and fungal richness were observed while soil $C N\left(F_{1,50}=1.411, p=0.241\right)$ and available phosphorus $\left(F_{1,50}\right.$ $=0.706, p=0.405$ ) did not affect fungal richness (Supplementary Figure $S$ 2.3.1). Stepwise backwards model selection was applied on a full multivariate linear model including tree diversity level and island size as well as soil nitrogen, $\mathrm{CN}, \mathrm{pH}$ and available phosphorus. The best model retained soil $\mathrm{pH}$ and nitrogen as explanatory variables, however the explained variation was low $\left(R^{2}=0.101, F_{2,49}=\right.$ 3.859, $\mathrm{p}=0.028$, Table 2.3.1).

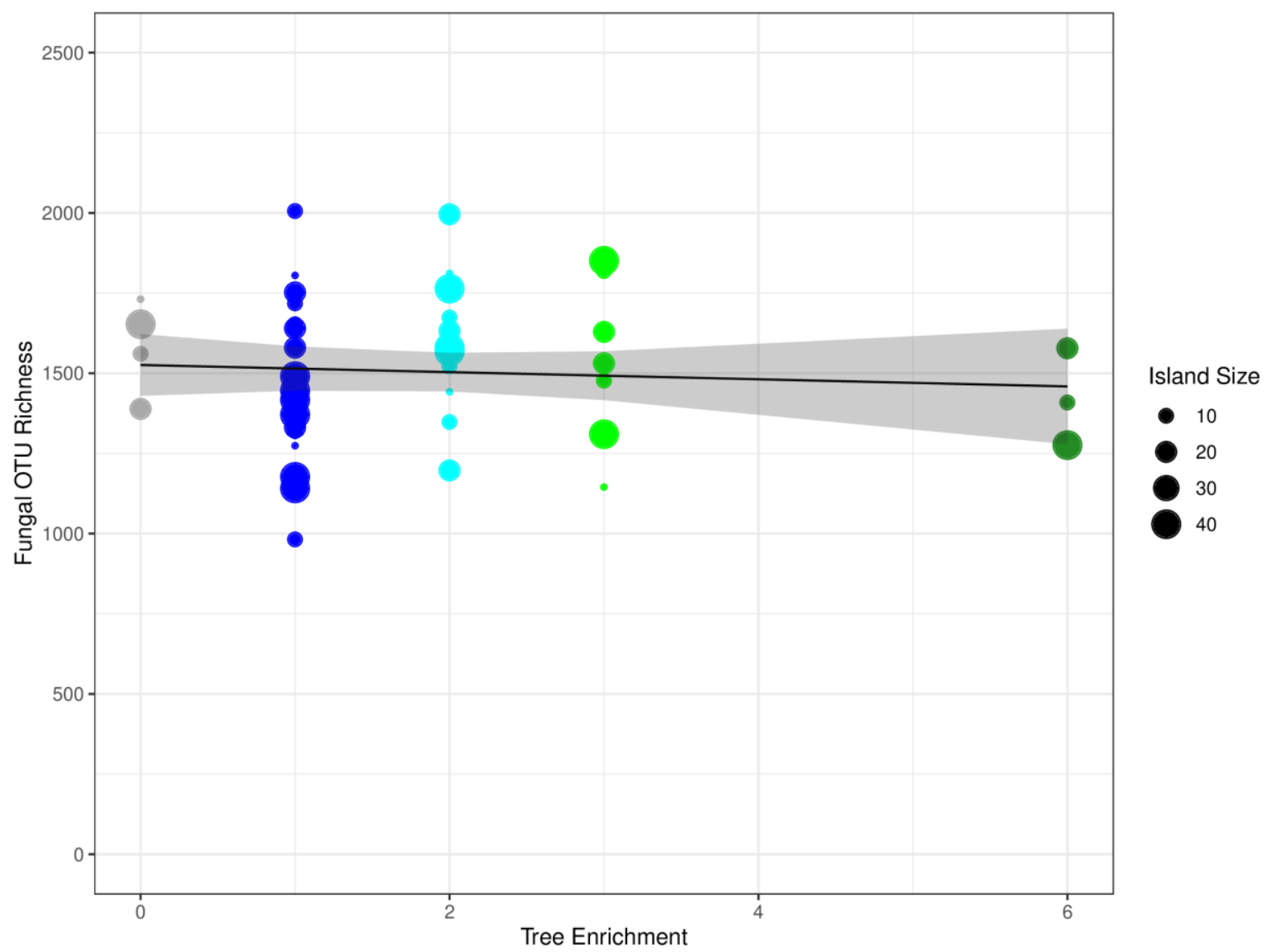

Figure 2.3.1 Fungal OTU richness as a function of tree species richness across all enrichment islands $(n=52)$. The number of Tree Enrichment corresponds to the number of additionally planted tree species. Oil palm density was reduced and management was stopped in all islands allowing for natural undergrowth succession. 
Table 2.3.1 Multivariate linear regression model showing the effect of environmental variables on fungal OTU richness. The initial model included tree species richness, tree island size, soil pH, CN, $\mathrm{N}$ and $P$ concentrations. Backwards variable selection was performed. The model with lowest Aikaike Information Criterion (AIC) was selected; $\beta$ = regression coefficient, $\mathrm{SE}=$ standard error

\begin{tabular}{lllll}
\hline Variables & $\beta$ & SE & t-value & p-value \\
\hline (intercept) & 5.905 & 643.05 & 0.993 & 0.993 \\
$\mathrm{pH}$ & 300.07 & 153.47 & 1.955 & 0.056 \\
$\mathrm{~N}$ & 147.698 & 73.72 & 2.003 & 0.051 \\
\hline
\end{tabular}

The most abundant fungal phyla were Ascomycota (45.4\%) followed by Basidiomycota (20.9 \%). Approximately $72.0 \%$ of all reads were taxonomically identified at the order level (Supplementary Table S 2.3.2, Figure 2.3.2 A). The most abundant orders were Hypocreales (Ascomycota), Pleosporales (Ascomycota) and Agaricales (Basidiomycota). However, no compositional change among fungal orders was observed between different tree diversity levels and conventionally managed sites (ANOSIM: $R=0.078 ; p=0.146$; Figure 2.3.2 A). Similarly we did not find differences in taxonomic composition between islands harboring different tree species (ANOSIM: $R=0.005 ; p=$ 0.466; Supplementary Figure S 2.3.2). Approximately $44 \%$ of the fungal reads could be assigned to a trophic mode (Supplementary Table S 2.3.2, Figure 2.3.1 B). We did not observe changes in the composition of trophic modes in the fungal communities between tree island diversity levels (ANOSIM: $R=-0.06 ; p=0.862$, Figure 2.3.2 B) 


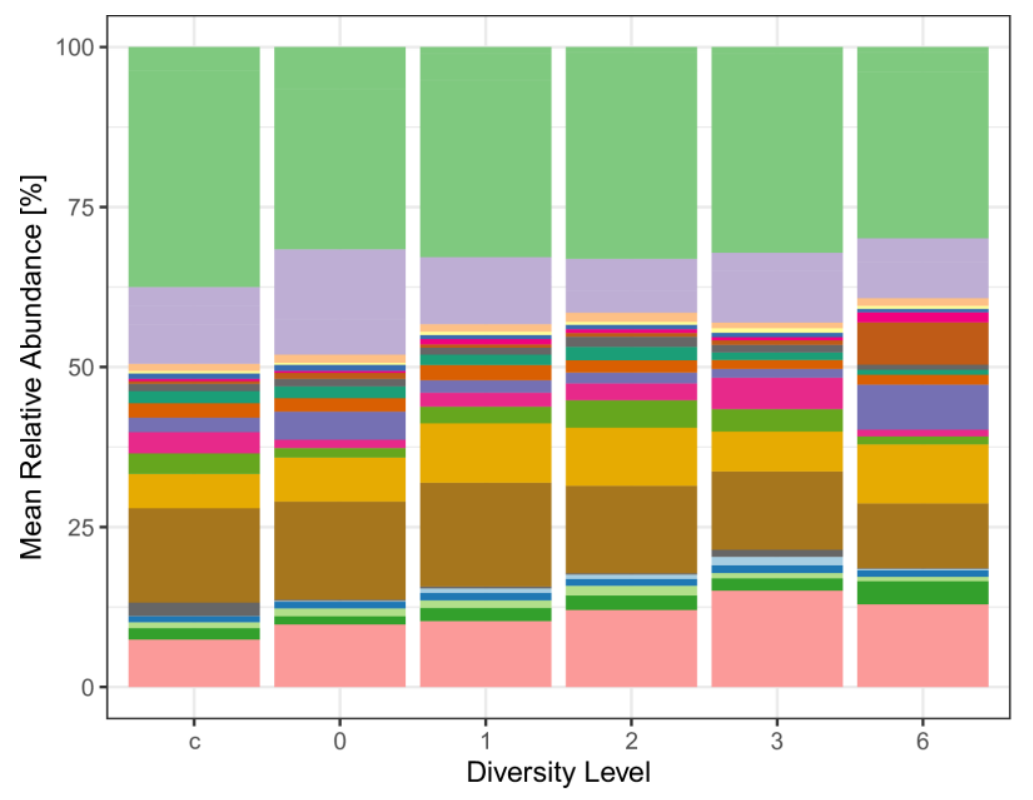

\section{Phylum}

\begin{tabular}{|l|l|}
\hline \multicolumn{1}{l}{ unidentified } & \multicolumn{1}{l}{ Eurotiales } \\
\cline { 2 - 2 } other & Sordariales \\
\hline Glomaeromycota & Pleosporales \\
\cline { 2 - 2 } Pezizales & Hypocreales \\
\hline Chaetothyriales & Hymenochaetales \\
\hline Magnaporthales & Phallales \\
\hline Helotiales & Polyporales \\
\hline Xylariales & Russulales \\
\hline Chaetosphaeriales & Tremellales \\
\hline Microascales & Agaricales \\
\hline Saccharomycetales & \\
\hline
\end{tabular}

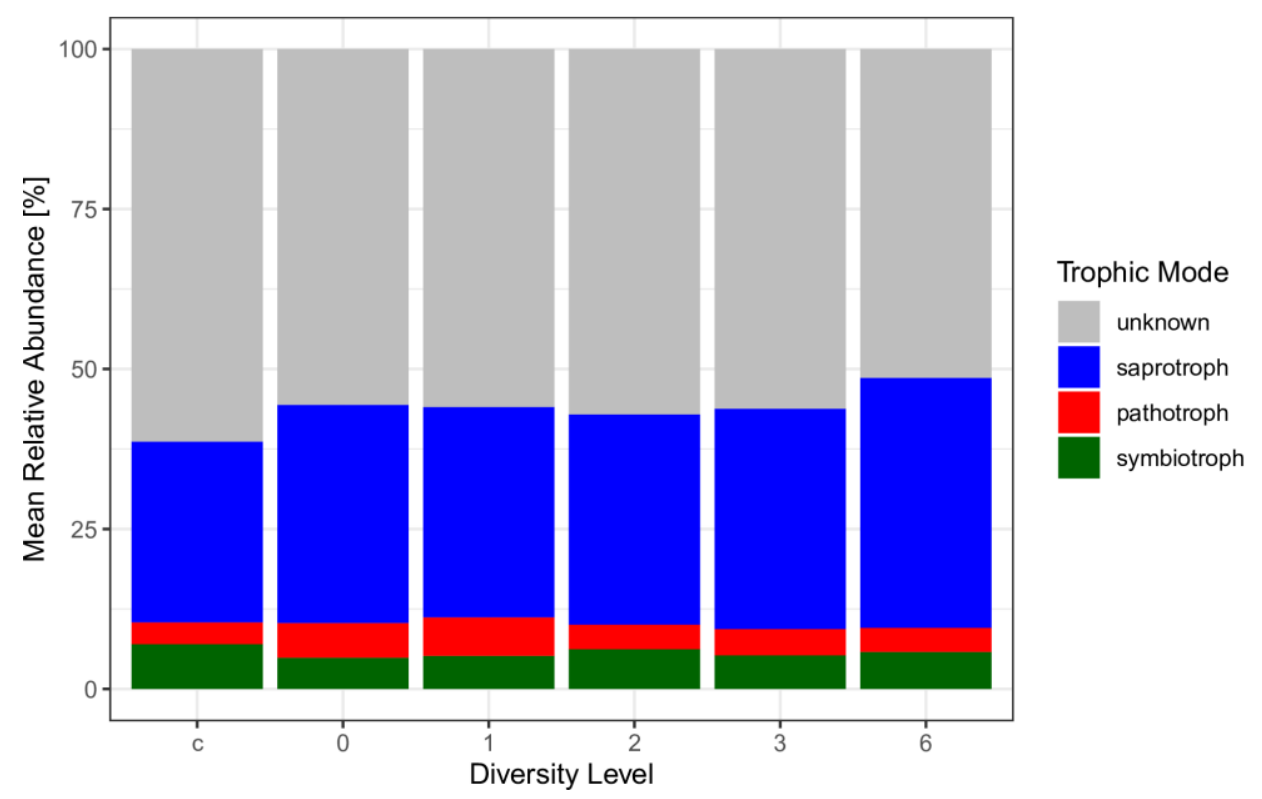

Figure 2.3.2 Mean relative abundance of fungal orders (A) and trophic groups (B) in tree islands with 0 to 6 additional planted tree species. Oil palm density was reduced and management was stopped in all islands allowing for natural undergrowth succession; $c=$ control sites under conventional management. 
No structuring effect by tree diversity on the fungal OTU community was observed (ANOSIM: $R=-$ $0.024 ; p=0.655)$. Composition of the fungal community across tree islands was analyzed using NMDS and the environmental variables tree island size, tree diversity level, presence of individual tree species as well as edaphic variables $(\mathrm{pH}, \mathrm{N}, \mathrm{CN}, \mathrm{P})$ were fit to the ordination. Despite low variability, soil nitrogen, $\mathrm{CN}$ ratio and phosphorus concentration were significantly associated with the fungal community structure (Figure 2.3.3). Constrained ordination (distance-based Redundancy Analysis) was used to further explore the structuring effect of the environmental variables on the soil fungal community composition. Stepwise backwards model selection was applied on the full ordination model including tree diversity level, tree species, island size, soil nitrogen, $\mathrm{CN}, \mathrm{pH}$ and phosphorus. In agreement with the results from the variable fit on the community ordination, the final model included soil nitrogen, $\mathrm{CN}$ and phosphorus; however only a low proportion of variation in the fungal community composition was explained by the model (Constrained Variation $=0.093 ; F_{3,48}=1.648, p=$ 0.001 (999 permutations); Table 2.3.2).

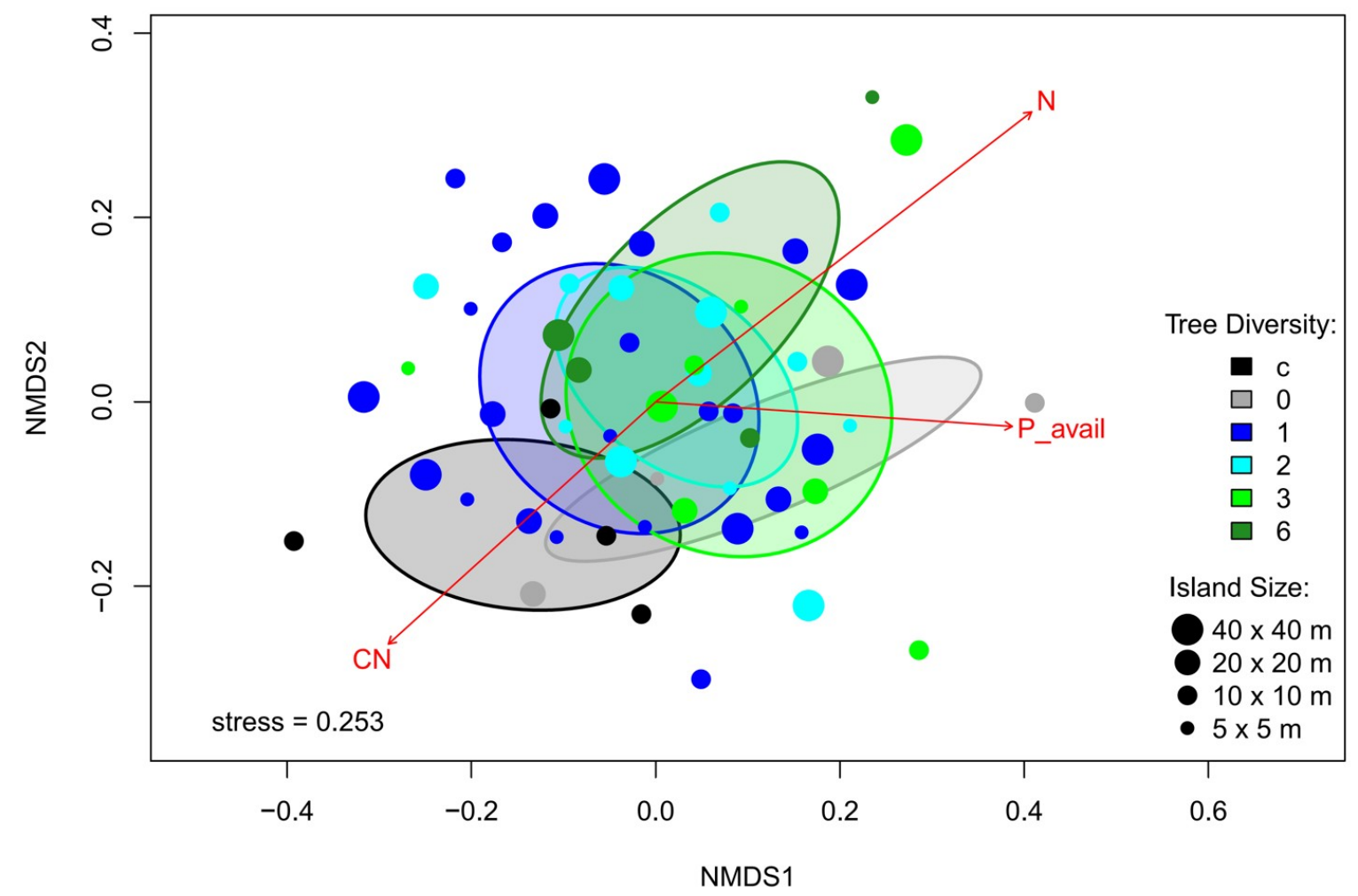

Figure 2.3.3 Non-metric multidimensional scaling (NMDS) of the soil fungal community dissimilarity measured as Bray-Curtis dissimilarity between all tree islands. In tree islands 0 to $\mathbf{6}$ additional tree species were planted. Oil palm density was reduced and management was stopped in all islands allowing for natural undergrowth succession; $c$ = control sites under conventionalmanagement. Ellipses represent standard errors from the centroid of each tree diversity level; red arrows show the linear effect of significant soil variables 
Table 2.3.2 Constrained ordination model showing the effect of environmental variables on fungal community composition. The initial model included tree diversity, tree island size, tree species identity, soil $\mathrm{pH}$, crabon to nitrogen $(\mathrm{CN})$, nitrogen $(\mathrm{N})$ and available phosphorpous (P) concentrations. Backwards variable selection was performed and only significant variables were retained in the model. $p$-values were estimated using permutation test with 999 permutations; df $=$ Degrees of Freedom, $\mathrm{SS}=$ Sum of Squares

\begin{tabular}{lllll}
\hline Variables & Df & SS & F-value & p-value \\
\hline $\mathrm{N}$ & 1 & 0.321 & 1.667 & 0.002 \\
$\mathrm{CN}$ & 1 & 0.252 & 1.310 & 0.015 \\
$\mathrm{P}$ & 1 & 0.307 & 1.592 & 0.001 \\
Residual & 48 & 9.242 & & \\
\hline
\end{tabular}

\section{Discussion}

Soil fungi play a crucial role in the recovery of ecosystems (Kardol \& Wardle, 2010) but only few studies addressed fungal communities in tropical forest restoration systems (Bachelot et al., 2016; Holste, Holl, Zahawi, \& Kobe, 2016; Reyes et al., 2019). To our knowledge, this study is the first to explore possibilities to restore fungal communities in intensively managed oil palm plantations. Tree diversity islands did not alter the soil fungal diversity or community composition compared to the surrounding plantation three years after tree planting and undergrowth succession. Soil nitrogen and phosphorous concentrations affected the fungal community composition but variation of measured edaphic variables among the study plotswas low. Therefore, a large proportion of variance in the fungal community remained unexplained. Our results highlight the strong legacy effect of intensive land-use on soil fungal communities and emphasize the potentially slow recovery of these systems.

Soil fungal species richness was neither affected by stopping the management nor increasing tree species richness. Transformation of tropical forest to oil palm and rubber monoculture had little effect on fungal species richness compared to the massive loss of plant diversity (Kerfahi, Tripathi, Dong, Go, \& Adams, 2016, cf. chapter 2.2). Therefore, we did not expect to observe an increase in fungal richness driven by tree diversity enrichment. However, in contrast to our results, the fungal community composition and functionality were altered in tropical land-transformation systems (Brinkmann et al., 2019; Kerfahi et al., 2014; McGuire et al., 2015, cf chapter 2.2). Since neither the taxonomic nor functional composition of the fungal community wasaffected by tree enrichment compared to regular management or increased tree diversity, our first hypothesis has to be rejected. Likewise, tree island size did not affect compositional turnover in the fungal community composition, thus our second hypothesis was rejected. We further did not find any structuring effect of tree 
identity. These results were surprising, because links between the vegetation structure and fungal community have frequently been observed and causal plant fungus relationships are generally assumed due to their numerous interactions (de Vries et al., 2012; Leff et al., 2018; RodríguezEcheverría et al., 2017; Yang et al., 2019). Our results suggest that there is a strong legacy effect on the fungal community, still overruling the structuring effects by the plant community. Supporting this explanation, long lasting land-use effects on the soil fungal community composition were demonstrated even after 80 years of natural succession from farming and logging in tropical forests of Puerto Rico (Bachelot et al., 2016). Furthermore, Chai et al., (2019) demonstrated that significant compositional differences of the fungal community between managed and recovering sites were only present after more than a decade of natural succession from farmland to secondary forest while no differences were found in early establishment phases (1-15 years after management stop). Agroforestry systems were demonstrated to promote compositional shifts in the fungal community and abundance of mycorrhizal fungi compared to monocultures for a variety of tropical crops, including coffee (Moreira, Celestino, Sobrinho, Cardoso, \& Elliot, 2019), cacao (Buyer et al., 2017) and rubber (Brinkmann et al., 2019). Therefore, despite our first results, we hypothesize that long term establishement of enriched tree islands could have similar beneifitial results in oil palm plantations. It is obvious that long term time series studies in enrichment systems are necessary to better understand how succession after intensive land-use affects the fungal community.

Soil abiotic drivers are heavily structuring the fungal communities in soil and can overrule potential plant regulatory effects (Peay et al., 2015; Schappe et al., 2017). In our study, homogenous conditions were found for soil variables typically driving soil fungal community composition (Bardgett \& van der Putten, 2014; Tedersoo et al., 2014, cf. Chapter 2.2). Therefore, it was not surprising that only a low proportion of community variation was explained by our models. Microbial communities are shaped by deterministic (e.g. environmental filtering) and niche-neutral processes such as dispersal limitation and stochastic community variation (Adams, Miletto, Taylor, \& Bruns, 2013; Brinkmann et al., 2019; Dumbrell, Nelson, Helgason, Dytham, \& Fitter, 2010; Powell et al., 2015). Ecologic drift (i.e. random population fluctuations) can dominate community assembly under homogenous environmental conditions (Bahram et al., 2016). Similar mechanisms may have strongly contributed to community variation in our study. Nevertheless, soil nutrients (nitrogen and available phosphorous) as well as carbon to nitrogen ratio partially determined soil fungal community composition in our study, despite the flat environmental gradient. Low nutrient and particularly low phosphorous concentrations are common in highly weathered tropical soils (Allen, Corre, Kurniawan, Utami, \& Veldkamp, 2016; Dalling, Heineman, Lopez, Wright, \& Turner, 2016; Turner, BrenesArguedas, \& Condit, 2018). Therefore, P and $\mathrm{N}$ availability are likely limiting factors for soil microorganisms; consequently, tight associations between soil nutrients and community composition 
are frequently occurring (Barnes, Maldonado, Frøslev, Antonelli, \& Rønsted, 2016; McGee, Eaton, Shokralla, \& Hajibabaei, 2018; Rodríguez-Echeverría et al., 2017; Tedersoo et al., 2014).

We did not observe a structuring effect by soil pH in our study. Soil pH influences the availability of nutrient elements as well as toxic cations (Glassman et al., 2017; Kluber et al., 2012; Sylvia, 2005). It is therefore postulated that soil $\mathrm{pH}$ is an important unifying driver of the belowground microbiome (Fierer \& Jackson, 2006; Fierer, 2017) and structuring effects of pH on the fungal community were demonstrated across steep gradients from acidic to basic soils (Rousk et al., 2010; Tedersoo et al., 2014) as well as smaller regional variations by one or two units (Glassman et al., 2017; Lauber, Strickland, Bradford, \& Fierer, 2008; Vasco-Palacios, Bahram, Boekhout, \& Tedersoo, 2019; cf. chapter 2.2). However, our results suggest that in relative homogenous habitats, dominated by anthropogenic land-use, the soil pH may not a major driver for the fungal community composition. We assume that the selective effect of $\mathrm{pH}$ is overruled by the strong legacy effect of land-use, resulting biotic homogenization (Gossner et al., 2016; Mueller, Rodrigues, Nüsslein, \& Bohannan, 2016).

In conclusion, we showed that short-term (three years) manipulation of the tree diversity and vegetation structure was not sufficient for the recovery of soil fungal communities from the effects of intensive management. However, this does not imply that effects of enrichment tree planting will have no long term positive effects on the soil microbiome. The root associated microbiome often differs significantly from the surrounding soil communities, which is likely linked to structuring plant effect (Danielsen et al. 2012; Zheng et al. 2017; Moll et al. 2016, cf. chapter 2.2). Agroforestry systems can promote the diversity, alter composition and improve resilience of root associated fungal communities (Bainard, Koch, Gordon, \& Klironomos, 2012; Chifflot, Rivest, Olivier, Cogliastro, \& Khasa, 2009; Furze et al., 2017) and those effects may feedback on surrounding soil after long-term establishment of tree islands. Studying further succession as well as analysis of the root associated communities of planted tree species could help to predict future effects of tree diversity enrichment on the soil microbiome in monoculture plantations. 


\section{Literature}

Abood, S. A., Lee, J. S. H., Burivalova, Z., Garcia-Ulloa, J., \& Koh, L. P. (2015). Relative contributions of the logging, fiber, oil palm, and mining industries to forest loss in Indonesia. Conservation Letters, 8(1), 5867. doi: $10.1111 /$ conl.12103

Adams, R. I., Miletto, M., Taylor, J. W., \& Bruns, T. D. (2013). Dispersal in microbes: Fungi in indoor air are dominated by outdoor air and show dispersal limitation at short distances. The ISME Journal, 7(7), 1262-1273. doi: 10.1038/ismej.2013.28

Allen, K., Corre, M. D., Kurniawan, S., Utami, S. R., \& Veldkamp, E. (2016). Spatial variability surpasses land-use change effects on soil biochemical properties of converted lowland landscapes in Sumatra, Indonesia. Geoderma, 284, 42-50. doi: 10.1016/j.geoderma.2016.08.010

Allen, K., Corre, M. D., Tjoa, A., \& Veldkamp, E. (2015). Soil nitrogen-cycling responses to conversion of lowland forests to oil palm and rubber plantations in Sumatra, Indonesia. PLOS ONE, 10(7), e0133325. doi: 10.1371/journal.pone.0133325

Bachelot, B., Uriarte, M., Zimmerman, J. K., Thompson, J., Leff, J. W., Asiaii, A., Koshner, J., \& McGuire, K. (2016). Long-lasting effects of land use history on soil fungal communities in second-growth tropical rain forests. Ecological Applications, 26(6), 1881-1895. doi: 10.1890/15-1397.1

Bahram, M., Kohout, P., Anslan, S., Harend, H., Abarenkov, K., \& Tedersoo, L. (2016). Stochastic distribution of small soil eukaryotes resulting from high dispersal and drift in a local environment. The ISME Journal, 10(4), 885-896. doi: 10.1038/ismej.2015.164

Bainard, L. D., Koch, A. M., Gordon, A. M., \& Klironomos, J. N. (2012). Temporal and compositional differences of arbuscular mycorrhizal fungal communities in conventional monocropping and tree-based intercropping systems. Soil Biology and Biochemistry, 45, 172-180. doi: 10.1016/j.soilbio.2011.10.008

Bardgett, R. D., \& van der Putten, W. H. (2014). Belowground biodiversity and ecosystem functioning. Nature, 515(7528), 505-511. doi: 10.1038/nature13855

Barnes, A. D., Allen, K., Kreft, H., Corre, M. D., Jochum, M., Veldkamp, E., Clough, Y., Daniel, R., Darras, L., Denmead, L. H., Haneda, N. F., Hertel, D., Knohl, A., Kotowska, M. M., Kurniawan, S., Meijide, A., Rembold, K., Prabowo, W. E., Schneider, D., Tscharntke, T., \& Brose, U. (2017). Direct and cascading impacts of tropical land-use change on multi-trophic biodiversity. Nature Ecology \& Evolution, 1(10), 1511-1519. doi: 10.1038/s41559-017-0275-7

Barnes, C. J., Maldonado, C., Frøslev, T. G., Antonelli, A., \& Rønsted, N. (2016). Unexpectedly high beta-diversity of root-associated fungal communities in the Bolivian Andes. Frontiers in Microbiology, 7. doi: 10.3389/fmicb.2016.01377

Bhagwat, S. A., Willis, K. J., Birks, H. J. B., \& Whittaker, R. J. (2008). Agroforestry: A refuge for tropical biodiversity? Trends in Ecology \& Evolution, 23(5), 261-267. doi: 10.1016/j.tree.2008.01.005

Bray, R., \& Kurtz, L. (1945). Determination of total, organic, and available forms of phosphorus in soil. Soil Science, 59(1), 39-46.

Brinkmann, N., Schneider, D., Sahner, J., Ballauff, J., Edy, N., Barus, H., Irawan, B., Budi, S. W., Qaim, M., Daniel, R., \& Polle, A. (2019). Intensive tropical land use massively shifts soil fungal communities. Scientific Reports, 9(1), 3403. doi: 10.1038/s41598-019-39829-4

Buyer, J. S., Baligar, V. C., He, Z., \& Arévalo-Gardini, E. (2017). Soil microbial communities under cacao agroforestry and cover crop systems in Peru. Applied Soil Ecology, 120, 273-280. doi: 10.1016/j.apsoil.2017.09.009

Grass, I., Kubitza, C., Krishna, V. V., Corre, M. D., Mußhoff, O., Pütz, P., Drescher, J., Rembold, K., Ariyanti, E. S., Barnes, A. D., Brinkmann, N., Brose, U., Brümmer, B., Buchori, D., Daniel, R., Darras, K. F. A., Faust, H., Fehrmann, L., Hain, J., Hennings, N., Hidayat, P., Hölscher, D., Jochum, M., Knohl, A., Kotowska, M. M., Krashevska, V., Kreft, H., Leuschner, C., Lobite, N. J. S., Panjaitan, R., Polle, A., Potapov, A. M., Purnama, E., Qaim, M., Röll, A., Scheu, S., Schneider, D., Tjoa, A., Tscharntke, T., Veldkamp, E., \& Wollni, M. (2020). Trade-offs between multifunctionality and profit in tropical smallholder landscapes. Nature Communications, 11(1), 1-13. doi: 10.1038/s41467-020-15013-5

Carrasco, L. R., Larrosa, C., Milner-Gulland, E. J., \& Edwards, D. P. (2014). A double-edged sword for tropical forests. Science, 346(6205), 38-40. doi: 10.1126/science.1256685 
Chai, Y., Cao, Y., Yue, M., Tian, T., Yin, Q., Dang, H., Quan, J., Ruichang, Z., \& Wang, M. (2019). Soil abiotic properties and plant functional traits mediate associations between soil microbial and plant communities during a secondary forest succession on the Loess Plateau. Frontiers in Microbiology, 10. doi: $10.3389 /$ fmicb.2019.00895

Chifflot, V., Rivest, D., Olivier, A., Cogliastro, A., \& Khasa, D. (2009). Molecular analysis of arbuscular mycorrhizal community structure and spores distribution in tree-based intercropping and forest systems. Agriculture, Ecosystems \& Environment, 131(1), 32-39. doi: 10.1016/j.agee.2008.11.010

Corbin, J., \& Holl, K. (2012). Applied nucleation as a forest restoration strategy. Forest Ecology and Management, (265), 37-46.

Dalling, J. W., Heineman, K., Lopez, O. R., Wright, S. J., \& Turner, B. L. (2016). Nutrient availability in tropical rain forests: The paradigm of phosphorus limitation. In G. Goldstein. \& L. S. Santiago (Eds.), Tropical tree physiology: Adaptations and responses in a changing environment (pp. 261-273). Berlin, Germany: Springer

Danielsen, L., Thürmer, A., Meinicke, P., Buée, M., Morin, E., Martin, F., Pilate, G., Daniel, R., Polle, A., Reich, M. (2012). Fungal soil communities in a young transgenic poplar plantation form a rich reservoir for fungal root communities. Ecology and Evolution, 2(8), 1935-1948. doi: 10.1002/ece3.305

de Carvalho, W. R., Vasconcelos, S. S., Kato, O. R., Capela, C. J. B., \& Castellani, D. C. (2014). Short-term changes in the soil carbon stocks of young oil palm-based agroforestry systems in the eastern Amazon. Agroforestry Systems, 88(2), 357-368. doi: 10.1007/s10457-014-9689-2

de Vries, F. T. de, Manning, P., Tallowin, J. R. B., Mortimer, S. R., Pilgrim, E. S., Harrison, K. A., Hobbs, P. J., Quirk, H., Shipley, B., Cornelissen, J. H. C., Kattge, J., \& Bardgett, R. D. (2012). Abiotic drivers and plant traits explain landscape-scale patterns in soil microbial communities. Ecology Letters, 15(11), 12301239. doi: 10.1111/j.1461-0248.2012.01844.x

Dislich, C., Keyel, A. C., Salecker, J., Kisel, Y., Meyer, K. M., Auliya, M., Barnes, A. D., Corre, M. D., Darras, K., Faust, H., Hess, B., Klasen, S., Knohl, A., Kreft, H., Meijide, A., Nurdiansyah, F., Otten, F., Pe'er, G., Steinebach, S., Tarigan, S., Tölle, M. H., Tschrntke, T., \& Wiegand, K. (2017). A review of the ecosystem functions in oil palm plantations, using forests as a reference system. Biological Reviews, 92(3), 15391569. doi: $10.1111 /$ brv.12295

Drescher, J., Rembold, K., Allen, K., Beckschäfer, P., Buchori, D., Clough, Y., Faust, H., Fauzi, A. M., Gunawan, D., \& Hertel, D. (2016). Ecological and socio-economic functions across tropical land use systems after rainforest conversion. Phil. Trans. R. Soc. B, 371(1694), 20150275.

Dumbrell, A. J., Nelson, M., Helgason, T., Dytham, C., \& Fitter, A. H. (2010). Relative roles of niche and neutral processes in structuring a soil microbial community. The ISME Journal, 4(3), 337-345.

Euler, M., Krishna, V., Schwarze, S., Siregar, H., \& Qaim, M. (2017). Oil palm adoption, household welfare, and nutrition among smallholder farmers in Indonesia. World Development, 93, 219-235. doi: 10.1016/j.worlddev.2016.12.019

Euler, M., Schwarze, S., Siregar, H., \& Qaim, M. (2016). Oil palm expansion among smallholder farmers in Sumatra, Indonesia. Journal of Agricultural Economics, 67(3), 658-676. doi: 10.1111/1477-9552.12163

Fierer, N. (2017). Embracing the unknown: Disentangling the complexities of the soil microbiome. Nature Reviews Microbiology, 15(10), 579-590. doi: 10.1038/nrmicro.2017.87

Fierer, N., \& Jackson, R. B. (2006). The diversity and biogeography of soil bacterial communities. Proceedings of the National Academy of Sciences, 103(3), 626-631. doi: 10.1073/pnas.0507535103

Fitzherbert, E. B., Struebig, M. J., Morel, A., Danielsen, F., Brühl, C. A., Donald, P. F., \& Phalan, B. (2008). How will oil palm expansion affect biodiversity? Trends in Ecology \& Evolution, 23(10), 538-545. doi: 10.1016/j.tree.2008.06.012

Foster, W. A., Snaddon, J. L., Turner, E. C., Fayle, T. M., Cockerill, T. D., Ellwood, M. D. F., Broad, G. R., Chung, A. Y. C., Eggleton, P., Khen, C. V., \& Yusah, K. M. (2011). Establishing the evidence base for maintaining biodiversity and ecosystem function in the oil palm landscapes of South East Asia. Philosophical Transactions of the Royal Society of London. Series B, Biological Sciences, 366(1582), 3277-3291. doi: 10.1098/rstb.2011.0041

Frąc, M., Hannula, S. E., Bełka, M., \& Jędryczka, M. (2018). Fungal biodiversity and their role in soil health. Frontiers in Microbiology, 9. doi: 10.3389/fmicb.2018.00707 
Furze, J. R., Martin, A. R., Nasielski, J., Thevathasan, N. V., Gordon, A. M., \& Isaac, M. E. (2017). Resistance and resilience of root fungal communities to water limitation in a temperate agroecosystem. Ecology and Evolution, 7(10), 3443-3454. doi: 10.1002/ece3.2900

Gérard, A., Wollni, M., Hölscher, D., Irawan, B., Sundawati, L., Teuscher, M., \& Kreft, H. (2017). Oil-palm yields in diversified plantations: Initial results from a biodiversity enrichment experiment in Sumatra, Indonesia. Agriculture, Ecosystems \& Environment, 240, 253-260. doi: 10.1016/j.agee.2017.02.026

Gibbs, H. K., Ruesch, A. S., Achard, F., Clayton, M. K., Holmgren, P., Ramankutty, N., \& Foley, J. A. (2010). Tropical forests were the primary sources of new agricultural land in the 1980s and 1990s. Proceedings of the National Academy of Sciences, 107(38), 16732-16737.

Glassman, S. I., Wang, I. J., \& Bruns, T. D. (2017). Environmental filtering by pH and soil nutrients drives community assembly in fungi at fine spatial scales. Molecular Ecology, 26(24), 6960-6973. doi: 10.1111/mec.14414

Gossner, M., Lewinsohn, T. M., Kahl, T., , Grassein, F., Boch, S., Prati, D., Birkhofer, K., Renner, S. C., Sikorski, J., Wubet T., Arndt, H., Baumgartner, V., Blaser, S., Blüthgen, N., Börschig, C., Buscot, F., Diekötter, T., Jorge, L. R., Jung, K., Keyel, A. C., Klein, A.-M., Klemmer, S., Krauss, J., Lange, M., Müller, J., Overmann, J., Pašalić, E., Penone, C., Perović, D. J., Purschke, O., Schall, P., Socher, S. A., Sonnemann, I., Tschapka, M., Tscharntke, T., Türke, M., Venter, P. C., Weiner, C. N., Werner, M., Wolters, V., Wurst, S., Westphal, C., Fischer, M., Weisser, W. W., \& Allan, E. (2016). Land-use intensification causes multitrophic homogenization of grassland communities. Nature, 540(7632), 266-269. doi: 10.1038/nature20575

Holste, E. K., Holl, K. D., Zahawi, R. A., \& Kobe, R. K. (2016). Reduced aboveground tree growth associated with higher arbuscular mycorrhizal fungal diversity in tropical forest restoration. Ecology and Evolution, 6(20), 7253-7262. doi: 10.1002/ece3.2487

Kardol, P., \& Wardle, D. A. (2010). How understanding aboveground-belowground linkages can assist restoration ecology. Trends in Ecology \& Evolution, 25(11), 670-679. doi: 10.1016/j.tree.2010.09.001

Kerfahi, D., Tripathi, B. M., Dong, K., Go, R., \& Adams, J. M. (2016). Rainforest conversion to rubber plantation may not result in lower soil diversity of bacteria, fungi, and nematodes. Microbial Ecology, 72(2), 359371. doi: 10.1007/s00248-016-0790-0

Kerfahi, D., Tripathi, B. M., Lee, J., Edwards, D. P., \& Adams, J. M. (2014). The impact of selective-logging and forest clearance for oil palm on fungal communities in Borneo. PLOS ONE, 9(11), e111525. doi: 10.1371/journal.pone.0111525

Kluber, L. A., Carrino-Kyker, S. R., Coyle, K. P., DeForest, J. L., Hewins, C. R., Shaw, A. N., Smemo, K. A., \& Burke, D. J. (2012). Mycorrhizal response to experimental $\mathrm{pH}$ and $\mathrm{P}$ manipulation in acidic hardwood forests. PLOS ONE, 7(11), e48946. doi: 10.1371/journal.pone.0048946

Koh, L. P., Levang, P., \& Ghazoul, J. (2009). Designer landscapes for sustainable biofuels. Trends in Ecology \& Evolution, 24(8), 431-438. doi: 10.1016/j.tree.2009.03.012

Kubitza, C., Krishna, V. V., Alamsyah, Z., \& Qaim, M. (2018). The economics behind an ecological crisis: Livelihood effects of oil palm expansion in Sumatra, Indonesia. Human Ecology, 46(1), 107-116. doi: 10.1007/s10745-017-9965-7

Lauber, C. L., Strickland, M. S., Bradford, M. A., \& Fierer, N. (2008). The influence of soil properties on the structure of bacterial and fungal communities across land-use types. Soil Biology and Biochemistry, 40(9), 2407-2415. doi: 10.1016/j.soilbio.2008.05.021

Leff, J. W., Bardgett, R. D., Wilkinson, A., Jackson, B. G., Pritchard, W. J., Long, J. R. D., Oakley, S., Mason, K. E., Ostle, N. J., Johnson, D., Baggs, E. M., \& Fierer, N. (2018). Predicting the structure of soil communities from plant community taxonomy, phylogeny, and traits. The ISME Journal, 12(7), 1794-1805. doi: 10.1038/s41396-018-0089-x

Legendre, P., \& Gallagher, E. D. (2001). Ecologically meaningful transformations for ordination of species data. Oecologia, 129(2), 271-280. doi: 10.1007/s004420100716

McGee, K. M., Eaton, W. D., Shokralla, S., \& Hajibabaei, M. (2018). Determinants of soil bacterial and fungal community composition toward carbon-use efficiency across primary and secondary forests in a Costa Rican conservation area. Microbial Ecology. doi: 10.1007/s00248-018-1206-0 
McGuire, K. L., D’Angelo, H., Brearley, F. Q., Gedallovich, S. M., Babar, N., Yang, N., Gillikin, C. M.,Gradoville, R., Bateman, C., Turner, B. L., Mansor, P., Leff, J. W., \& Fierer, N. (2015). Responses of soil fungi to logging and oil palm agriculture in Southeast Asian tropical forests. Microbial Ecology, 69(4), 733-747. doi: 10.1007/s00248-014-0468-4

Miettinen, J., Shi, C., \& Liew, S. C. (2011). Deforestation rates in insular Southeast Asia between 2000 and 2010 : Deforestation in insular Southeast Asia 2000-2010. Global Change Biology, 17(7), 2261-2270. doi: 10.1111/j.1365-2486.2011.02398.x

Moll, J., Hoppe, B., König, S., Wubet, T., Buscot, F., \& Krüger, D. (2016). Spatial Distribution of fungal communities in an arable soil. PLOS ONE, 11(2), e0148130. doi: 10.1371/journal.pone.0148130

Moreira, C. C., Celestino, D., Sobrinho, T. G., Cardoso, I. M., \& Elliot, S. L. (2019). Agroforestry coffee soils increase the insect-suppressive potential offered by entomopathogenic fungi over full-sun soils: A case proposing a "bait survival technique". Ecology and Evolution, 9(18), 10777-10787. doi: 10.1002/ece3.5598

Mueller, R. C., Rodrigues, J. L. M., Nüsslein, K., \& Bohannan, B. J. M. (2016). Land use change in the Amazon rain forest favours generalist fungi. Functional Ecology, 30(11), 1845-1853. doi: 10.1111/1365-2435.12651

Nguyen, N. H., Song, Z., Bates, S. T., Branco, S., Tedersoo, L., Menke, J., Schilling, J. S., \& Kennedy, P. G. (2016). FUNGuild: An open annotation tool for parsing fungal community datasets by ecological guild. Fungal Ecology, 20, 241-248. doi: 10.1016/j.funeco.2015.06.006

Obidzinski, K., Andriani, R., Komarudin, H., \& Andrianto, A. (2012). Environmental and social impacts of oil palm plantations and their implications for biofuel production in Indonesia. Ecology and Society, 17(1). doi: 10.5751/ES-04775-170125

Oksanen, J., Blanchet, F. G., Friendly, M., Kindt, R., Legendre, P., McGlinn, D., Minchin, P. R., O’Hara, R. B., Simpson, G. L., Solymos, P., Stevens, M. H. H., Szoecs, E., \& Wagner, H. (2019). vegan: Community Ecology Package version 2.5-6.

Peay, K. G., Russo, S. E., McGuire, K. L., Lim, Z., Chan, J. P., Tan, S., \& Davies, S. J. (2015). Lack of host specificity leads to independent assortment of dipterocarps and ectomycorrhizal fungi across a soil fertility gradient. Ecology Letters, 18(8), 807-816. doi: 10.1111/ele.12459

Philippot, L., Raaijmakers, J. M., Lemanceau, P., \& van der Putten, W. H. (2013). Going back to the roots: The microbial ecology of the rhizosphere. Nature Reviews Microbiology, 11(11), 789-799. doi: 10.1038/nrmicro3109

Powell, J. R., Karunaratne, S., Campbell, C. D., Yao, H., Robinson, L., \& Singh, B. K. (2015). Deterministic processes vary during community assembly for ecologically dissimilar taxa. Nature Communications, 6, 8444. doi: $10.1038 /$ ncomms9444

R Core Team. (2019). R: A language and environment for statistical computing. R Foundation for Statistical Computing, Vienna, Austria.

Ramos, H. M. N., Vasconcelos, S. S., Kato, O. R., \& Castellani, D. C. (2018). Above- and belowground carbon stocks of two organic, agroforestry-based oil palm production systems in eastern Amazonia. Agroforestry Systems, 92(2), 221-237. doi: 10.1007/s10457-017-0131-4

Rembold, K., Mangopo, H., Tjitrosoedirdjo, S. S., \& Kreft, H. (2017). Plant diversity, forest dependency, and alien plant invasions in tropical agricultural landscapes. Biological Conservation, 213, 234-242. doi: 10.1016/j.biocon.2017.07.020

Reyes, H. A., Ferreira, P. F. A., Silva, L. C., da Costa, M. G., Nobre, C. P., \& Gehring, C. (2019). Arbuscular mycorrhizal fungi along secondary forest succession at the eastern periphery of Amazonia: Seasonal variability and impacts of soil fertility. Applied Soil Ecology, 136, 1-10. doi: 10.1016/j.apsoil.2018.12.013

Rillig, M. C. (2004). Arbuscular mycorrhizae and terrestrial ecosystem processes. Ecology Letters, 7(8), 740-754. doi: 10.1111/j.1461-0248.2004.00620.x

Rodríguez-Echeverría, S., Teixeira, H., Correia, M., Timóteo, S., Heleno, R., Öpik, M., \& Moora, M. (2017). Arbuscular mycorrhizal fungi communities from tropical Africa reveal strong ecological structure. New Phytologist, 213(1), 380-390. doi: 10.1111/nph.14122

Rousk, J., Bååth, E., Brookes, P. C., Lauber, C. L., Lozupone, C., Caporaso, J. G., Knight, R., \& Fierer, N. (2010). Soil bacterial and fungal communities across a pH gradient in an arable soil. The ISME Journal, 4(10), 1340-1351. doi: 10.1038/ismej.2010.58 
Sayer, J., Ghazoul, J., Nelson, P., \& Klintuni Boedhihartono, A. (2012). Oil palm expansion transforms tropical landscapes and livelihoods. Global Food Security, 1(2), 114-119. doi: 10.1016/j.gfs.2012.10.003

Schappe, T., Albornoz, F. E., Turner, B. L., Neat, A., Condit, R., \& Jones, F. A. (2017). The role of soil chemistry and plant neighbourhoods in structuring fungal communities in three Panamanian rainforests. Journal of Ecology, 105(3), 569-579. doi: 10.1111/1365-2745.12752

Schroth, G., Izac, A.-M. N., Vasconcelos, H. L., Gascon, C., Fonseca, G. A. B. da, \& Harvey, C. A. (2004). Agroforestry and biodiversity conservation in tropical landscapes. Washington D. C., USA: Island Press.

Smith, S. E., Jakobsen, I., Grønlund, M., \& Smith, F. A. (2011). Roles of arbuscular mycorrhizas in plant phosphorus nutrition: Interactions between pathways of phosphorus uptake in arbuscular mycorrhizal roots have important implications for understanding and manipulating plant phosphorus acquisition. Plant Physiology, 156(3), 1050-1057. doi: 10.1104/pp.111.174581

Sylvia, D. M. (2005). Principles and Applications of Soil Microbiology. New Jersey, USA: Pearson Prentice Hall.

Tedersoo L., Bahram, M., , Põlme, S., Kõljalg, U., Yorou, N. S., Wijesundera, R., Ruiz, L. V., Vasco-Palacios, A. M., Thu, P. Q., Suija, A., Smith M. E., Sharp, C., Saluveer, E., Saitta A., Rosas, M., Riit, T., Ratkowsky, D., Pritsch, K., Põldmaa, K., Piepenbring, M., Phosri, C., Peterson, M., Parts, K., Pärtel, K., Otsing, E., Nouhra, E., Njouonkou, A. L, Nilsson, R. H., Morgado, L. N., Mayor, J., May T. W., Majuakim, L., Lodge D. J., Lee, S. S., Larsson K.-H., Kohout, P., Hosaka, K., Hiiesalu I., Henkel, T. W., Harend, H., Guo, L., Greslebin, A., Grelet G., Geml, J., Gates, G., Dunstan, W., Dunk, C., Drenkhan, R., Dearnaley, J., de Kesel, A., Dang T., Chen, X., Buegger F., Brearley, F. Q., Bonito, G., Anslan S., Abell S., Abarenkov K. (2014). Global diversity and geography of soil fungi. Science, 346(6213), 1256688-1256688. doi: 10.1126/science. 1256688

Tedersoo, Leho, Bahram, M., \& Dickie, I. A. (2014). Does host plant richness explain diversity of ectomycorrhizal fungi? Re-evaluation of Gao et al. (2013) data sets reveals sampling effects. Molecular Ecology, 23(5), 992-995.

Teuscher, M., Gérard, A., Brose, U., Buchori, D., Clough, Y., Ehbrecht, M., Hölscher, D., Irawan, B., Sundawati, L., Wollni, M., \& Kreft, H. (2016). Experimental biodiversity enrichment in oil-palm-dominated landscapes in Indonesia. Frontiers in Plant Science, 7. doi: 10.3389/fpls.2016.01538

Toju, H., Tanabe, A. S., Yamamoto, S., \& Sato, H. (2012). High-coverage ITS primers for the DNA-based identification of Ascomycetes and Basidiomycetes in environmental samples. PLoS ONE, 7(7), e40863. doi: 10.1371/journal.pone.0040863

Tscharntke, T., Clough, Y., Bhagwat, S. A., Buchori, D., Faust, H., Hertel, D., Hölscher, D., Juhrbandt, J., Kessler, M., Perfecto, I., Scherber, C., Schroth, G., Veldkamp, E., \& Wanger, T. C. (2011). Multifunctional shadetree management in tropical agroforestry landscapes - a review. Journal of Applied Ecology, 619-629.

Turner, B. L., Brenes-Arguedas, T., \& Condit, R. (2018). Pervasive phosphorus limitation of tree species but not communities in tropical forests. Nature, 555(7696), 367-370. doi: 10.1038/nature25789

van der Heijden, M. G. A., Bardgett, R. D., \& van Straalen, N. M. (2008). The unseen majority: Soil microbes as drivers of plant diversity and productivity in terrestrial ecosystems. Ecology Letters, 11(3), 296-310. doi: 10.1111/j.1461-0248.2007.01139.x

van der Heijden, M. G. A., Dombrowski, N., \& Schlaeppi, K. (2017). Continuum of root-fungal symbioses for plant nutrition. Proceedings of the National Academy of Sciences, 114(44), 11574-11576. doi: 10.1073/pnas.1716329114

Vasco-Palacios, A. M., Bahram, M., Boekhout, T., \& Tedersoo, L. (2019). Carbon content and pH as important drivers of fungal community structure in three Amazon forests. Plant and Soil. doi: 10.1007/s11104019-04218-3

Vijay, V., Pimm, S. L., Jenkins, C. N., \& Smith, S. J. (2016). The impacts of oil palm on recent deforestation and biodiversity loss. PLOS ONE, 11(7). doi: 10.1371/journal.pone.0159668

White, T. J., Bruns, T., Lee, S., \& Taylor, J. (1990). Amplification and direct sequencing of fungal ribosomal RNA genes for phylogenetics. In M. A. Innis, D. H. Gelfand, J. J. Sninsky, \& T. J. White (Eds.), PCR protocols: $A$ guide to methods and applications (pp. 315-322). Cambridge, USA: Academic Press

Wilcove, D. S., \& Koh, L. P. (2010). Addressing the threats to biodiversity from oil-palm agriculture. Biodiversity and Conservation, 19(4), 999-1007. doi: 10.1007/s10531-009-9760-x 
Yang, T., Tedersoo, L., Soltis, P. S., Soltis, D. E., Gilbert, J. A., Sun, M., Shi, Y., Wang, H., Li, Y., Zhang, J., Chen, Z., Lin, H., Zhao, Y., Fu, C., \& Chu, H. (2019). Phylogenetic imprint of woody plants on the soil mycobiome in natural mountain forests of eastern China. The ISME Journal, 13(3), 686-697. doi: 10.1038/s41396018-0303-x

Zemp, D. C., Ehbrecht, M., Seidel, D., Ammer, C., Craven, D., Erkelenz, J., Irawan , B., Sundawati, L., Hölscher, D., \& Kreft, H. (2019). Mixed-species tree plantings enhance structural complexity in oil palm plantations. Agriculture, Ecosystems \& Environment, 283, 106564. doi: 10.1016/j.agee.2019.06.003

Zemp, D. C., Gérard, A., Hölscher, D., Ammer, C., Irawan, B., Sundawati, L., Teuscher, M., \& Kreft, H. (2019). Tree performance in a biodiversity enrichment experiment in an oil palm landscape. Journal of Applied Ecology, 56(10), 2340-2352. doi: 10.1111/1365-2664.13460

Zhang, X., Gao, G., Wu, Z., Wen, X., Zhong, H., Zhong, Z., Bian, F., \& Gai, X. (2019). Agroforestry alters the rhizosphere soil bacterial and fungal communities of moso bamboo plantations in subtropical China. Applied Soil Ecology, 143, 192-200. doi: 10.1016/j.apsoil.2019.07.019

Zheng, Y., Hu, H.-W., Guo, L.-D., Anderson, I. C., \& Powell, J. R. (2017). Dryland forest management alters fungal community composition and decouples assembly of root- and soil-associated fungal communities. Soil Biology and Biochemistry, 109, 14-22. doi: 10.1016/j.soilbio.2017.01.024 


\section{Declaration of other contributions}

The enrichment experiment was designed by Prof. Dr. Holger Kreft (Biodiversity, Macroecology and Biogeography, University of Goettingen), Prof. Dr. Dirk Hölscher (Tropical Silviculture and Forest Ecology, University of Goettingen), Dr. Irawan Bambang (Faculty of Forestry, University of Jambi, Indonesia), Dr. Clara Zemp (Biodiversity, Macroecology and Biogeography, University of Goettingen) and others. They provided data on the tree diversity, island sizes and tree species composition; Nina Henings (Soil Science of Temperate Ecosystems, University of Goettingen) measured soil pH and Dr. Dominik Schneider (Genomic and Applied Microbiology and Göttingen Genomics Laboratory, University of Goettingen) performed the bioinformatic processing of the raw sequences. 


\section{Supplementary Information}

Supplementary Table S 2.3.1 Tree enrichment island size (edge length), tree pecies richness levels, planted tree species and soil chemical measurements. $D Z=$ Durio zibethinus; $D P=$ Dyera polyphylla; $\mathrm{AP}=$ Archidendron pauciflorum; $\mathrm{SL}=$ Shorea leprosula; $\mathrm{PS}=$ Parkia speciosa; $\mathrm{PC}=$ Peronema canescens

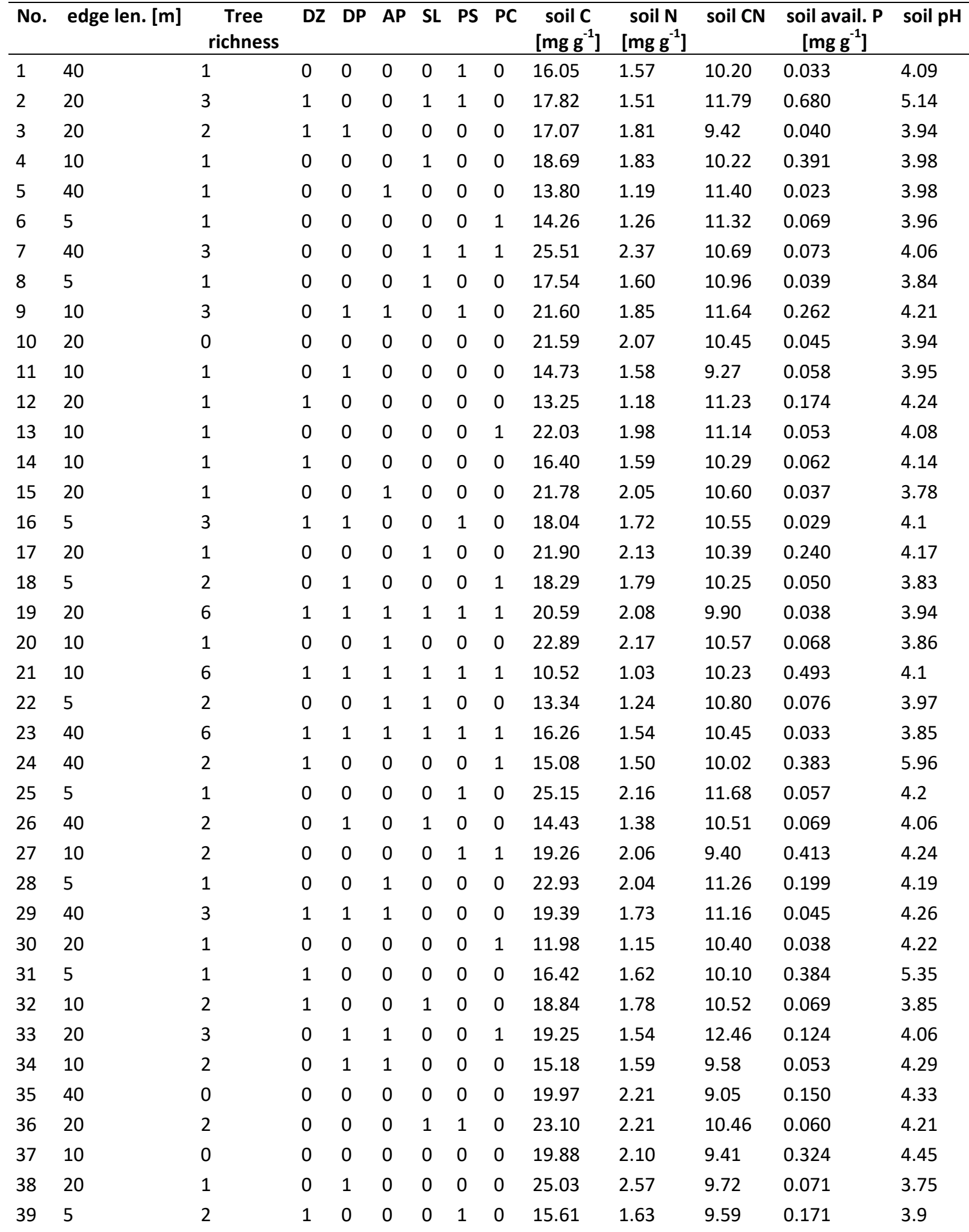


Supplementray Table S 2.3.1 continued

\begin{tabular}{|c|c|c|c|c|c|c|c|c|c|c|c|c|c|}
\hline No. & edge len. [m] & $\begin{array}{c}\text { Tree } \\
\text { richness }\end{array}$ & DZ & DP & AP & SL & PS & PC & $\begin{array}{c}\text { soil C } \\
{\left[\mathrm{mg} \mathrm{g}^{-1}\right]}\end{array}$ & $\begin{array}{c}\text { soil } \mathrm{N} \\
{\left[\mathrm{mg} \mathrm{g}^{-1}\right]}\end{array}$ & soil CN & $\begin{array}{c}\text { soil avail. P } \\
{\left[\mathrm{mg} \mathrm{g}^{-1}\right]}\end{array}$ & soil pH \\
\hline 40 & 5 & 0 & 0 & 0 & 0 & 0 & 0 & 0 & 19.23 & 1.87 & 10.24 & 0.050 & 3.98 \\
\hline 41 & 10 & 1 & 0 & 0 & 0 & 0 & 1 & 0 & 13.74 & 1.26 & 10.91 & 0.063 & 3.97 \\
\hline 42 & 5 & 1 & 0 & 1 & 0 & 0 & 0 & 0 & 15.30 & 1.37 & 11.26 & 0.037 & 3.97 \\
\hline 43 & 40 & 1 & 1 & 0 & 0 & 0 & 0 & 0 & 21.41 & 1.79 & 12.09 & 0.089 & 4.25 \\
\hline 44 & 5 & 3 & 0 & 0 & 1 & 1 & 0 & 1 & 14.95 & 1.61 & 9.27 & 0.052 & 4.09 \\
\hline 45 & 40 & 1 & 0 & 0 & 0 & 0 & 0 & 1 & 27.11 & 2.89 & 9.37 & 0.068 & 4.1 \\
\hline 46 & 40 & 2 & 0 & 0 & 1 & 0 & 1 & 0 & 34.66 & 3.62 & 9.54 & 0.084 & 6.32 \\
\hline 47 & 20 & 2 & 0 & 0 & 1 & 0 & 0 & 1 & 18.56 & 2.15 & 8.64 & 0.053 & 4.5 \\
\hline 48 & 10 & 3 & 1 & 0 & 0 & 1 & 0 & 1 & 14.43 & 1.46 & 10.02 & 0.274 & 4.56 \\
\hline 49 & 40 & 1 & 0 & 0 & 0 & 1 & 0 & 0 & 13.52 & 1.32 & 10.21 & 0.058 & 4.36 \\
\hline 50 & 5 & 6 & 1 & 1 & 1 & 1 & 1 & 1 & 22.45 & 2.16 & 10.46 & 0.064 & 4.1 \\
\hline 51 & 20 & 1 & 0 & 0 & 0 & 0 & 1 & 0 & 18.54 & 1.57 & 11.55 & 0.038 & 3.77 \\
\hline 52 & 40 & 1 & 0 & 1 & 0 & 0 & 0 & 0 & 16.31 & 1.43 & 11.39 & 0.526 & 4.38 \\
\hline 53 & 10 & c & 0 & 0 & 0 & 0 & 0 & 0 & 15.41 & 1.26 & 11.92 & 0.272 & 3.94 \\
\hline 54 & 10 & c & 0 & 0 & 0 & 0 & 0 & 0 & 13.98 & 1.18 & 11.83 & 0.034 & 4.16 \\
\hline 55 & 10 & c & 0 & 0 & 0 & 0 & 0 & 0 & 20.30 & 1.69 & 12.12 & 0.040 & 4.29 \\
\hline 56 & 10 & c & 0 & 0 & 0 & 0 & 0 & 0 & 15.52 & 1.48 & 10.53 & 0.030 & 4.2 \\
\hline
\end{tabular}

Supplementary Table S 2.3.2 Rarefied read counts of fungal operational taxonomic units (OTU; clustered at $\mathbf{9 7} \%$ similarity threshold) for all tree islands and reference plots. (coluns $1-57$ ) as well as their taxonomic affiliation (columns 58 - 68)

See digital supplement supp/Table_S232.xIxs 

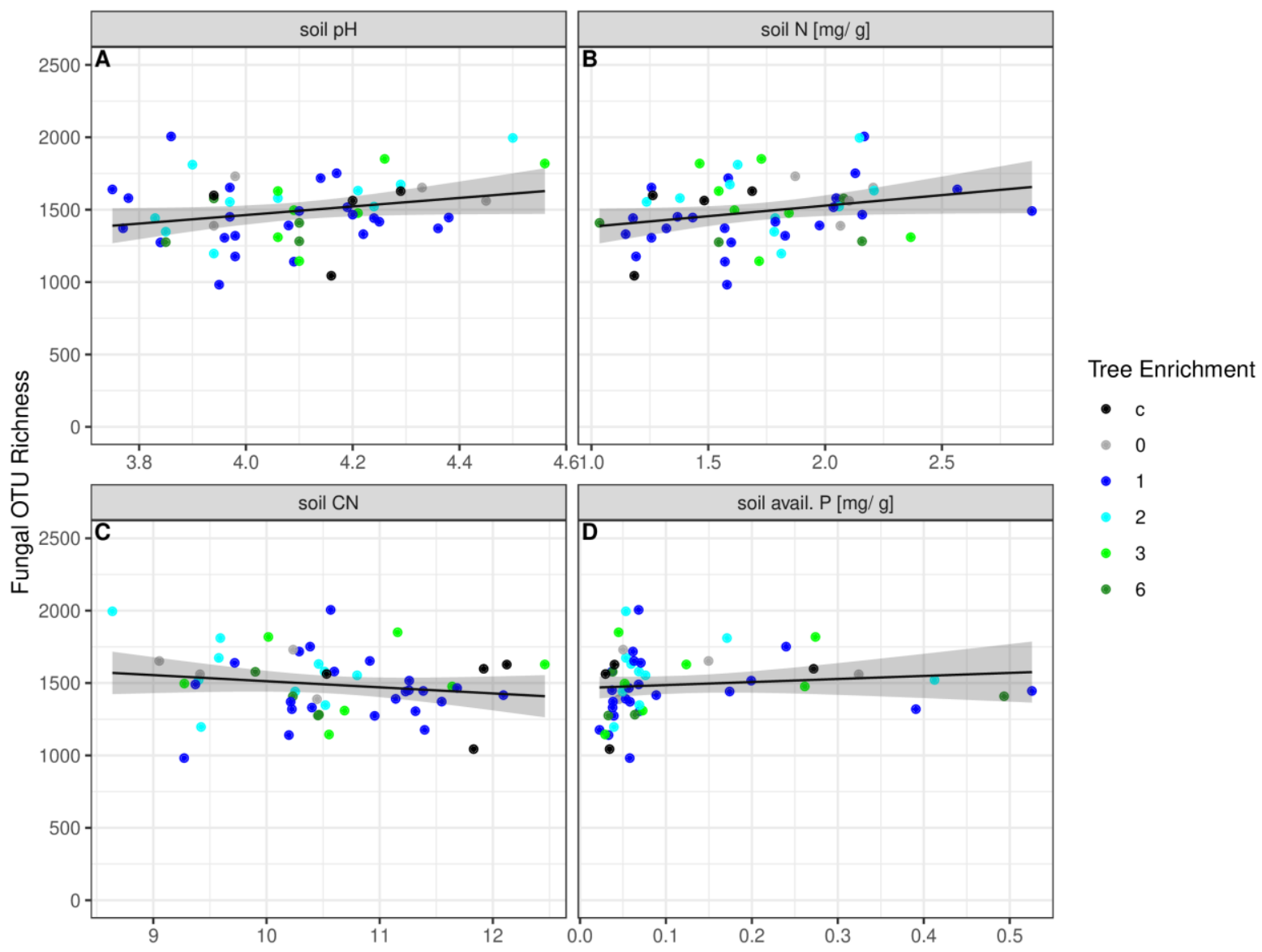

Supplementary Figure $S$ 2.3.1 Fungal OTU richness as a function of soil pH (A), soil nitrogen (B), soil carbon to nitrogen ratio (C) and soil available phosphorous (D); $n=52$; colors denote tree island diversity; $\mathrm{c}=$ conventionally managed sites 


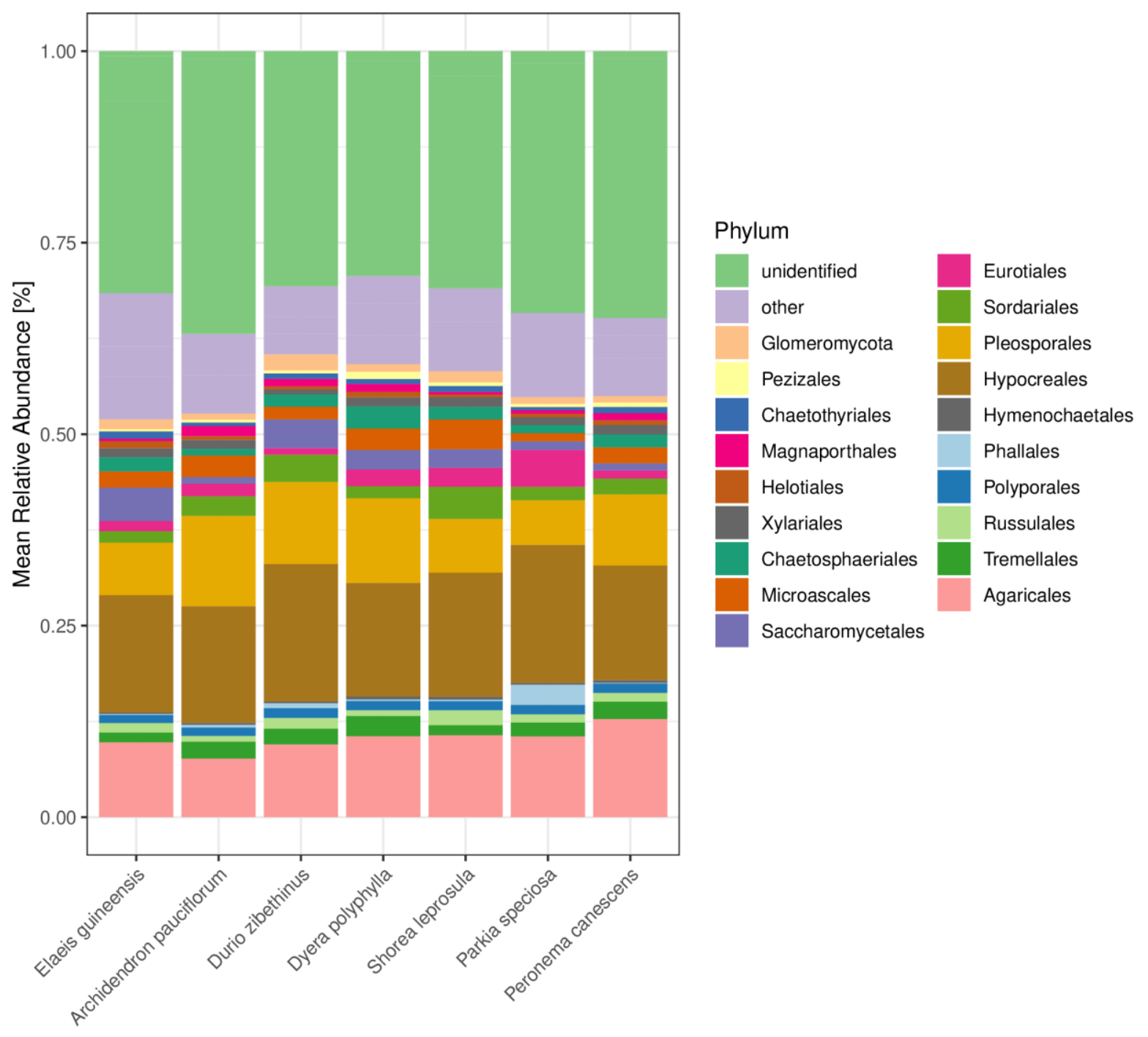

Supplementary Figure $S$ 2.3.2 Mean relative abundance of fungal orders in tree islands with one additional tree species planted. Density of oil plam ( $E$. guineensis) was reduced and management was stopped in all islands allowing for natural undergrowth succession. The first lefthand bar represents the tree islands were no additional treespecies was planted. 


\section{Synthesis}

In this thesis, I analyzed the effects of anthropogenic land-transformation in tropical ecosystems on the diversity, abundance, and composition of the belowground fungal microbiome. I demonstrated severe land-use induced compositional shifts in the soil as well as in the root-associated fungal biomes. These results are in line with studies from other transformations systems also reporting differences in soil fungal community structures (Kerfahi, Tripathi, Dong, Go, \& Adams, 2016; Kerfahi, Tripathi, Lee, Edwards, \& Adams, 2014; McGuire et al., 2015; Mueller et al., 2014; Mueller, Rodrigues, Nüsslein, \& Bohannan, 2016). Moreover, the present study is one of the few comparing fungal communities in natural rainforests with several major tropical transformation systems (jungle rubber, rubber and oil palm plantations) (Berkelmann, Schneider, Meryandini, \& Daniel, 2020; Brinkmann et al., 2019). Thereby, this thesis extends current knowledge on the assembly of fungal communities under human land-use. In-depth analysis on the effect of land-use intensity on root associated mycorrhizal fungi across land-use systems is provided (chapter 2.1). The effects of changes in edaphic properties and plant root community traits on the composition of root and soil associated fungal communities were disentangled (chapter 2.2). Finally, short-term effects after three years of vegetation diversity enrichment in a formerly intensively managed oil palm plantation on the soil fungal community structure were investigated (chapter 2.3). Empirical findings and detailed discussions of these aspects are presented in the respective research chapters. In the following, the main findings are put into context to develop a conceptual framework on how anthropogenic land-use drives the assembly and function of the belowground fungal microbiome and to discuss the implications of these findings for future research.

Different land-use systems harbor distinct fungal communities associated with roots and soil (chapter 2.2) and a characteristic composition of AM communities (chapter 2.1), overruling a structuring effect by landscape. I demonstrated that the spatial effect on fungal community dissimilarity ("distance decay") was small compared to the effect of environmental filters (chapter 2.2). The hypothesis "everything is everywhere, but environment selects" was originally proposed by Baas Becking (1934) to characterize the high dispersal ability and niche based assembly of microbial communities, and as has been under critical evaluation ever since (Fuhrman, 2009). A number of recent studies utilizing next generation sequencing also challenged this view by demonstrating that niche neutral processes (e.g. dispersal limitation) indeed contribute to the assembly of microbial communities (Davison et al., 2015; Peay, Bidartondo, \& Arnold, 2010; Taylor, Turner, Townsend, Dettman, \& Jacobson, 2006; Tedersoo et al., 2014). Therefore, the "everything-everwhere" paradigm cannot be kept. Nevertheless, in this thesis, I observed only a minor effect of spatial distance on 
fungal community structures, thus, suggesting that on the regional scale (approximately $120 \mathrm{~km}$ ) of this work the fungal community is mainly determined by environmental conditions (chapter 2.2). In agreement with this result, other studies found low impact of spatial distance on the assembly of fungal communities across scales of several hundred kilometers (Beng \& Corlett, 2019; Kivlin, Winston, Goulden, \& Treseder, 2014). The local fungal communities were, therefore, likely recruited from a larger species pool present in our study region, which I consider further-on as the regional species pool (Figure 3.1). A regional species pool implicates that, e.g., protected habitats such as the Natural Forest Reservations "PT Restorasi Ekosistem Indonesia" (Harapan landscape) or "Bukit Duabelas" (Bukit landscape) could serve as a reservoir for naturally occurring fungal species contributing to the succession of local fungal communities after recovery from human land-use. However, it remains unclear at which spatial and temporal scale this species pool may contribute to the assembly of local communities. Up-scaling the assessment of fungal communities across land-use systems including larger environmental gradients and reduced oil palm management practices (Darras et al., 2019), will be required to further disentangle the effects of environmental filters and niche neutral processes on the assembly of local fungal communities.

Land use intensity (LUI) has a strong negative on the diversity and abundance of root associated AM fungi (Chapter 2.1). In contrast, the effect of land-use systems on the diversity of the overall fungal community did not reveal a clearly declining pattern (Brinkmann et al., 2019, chapter 2.2), underpinning the specific susceptibility of AM. AM fungi, all belonging to the phylum of the Glomeromycota, are key mutualists for the majority of land plants although their overall diversity and abundance is very low compared to the hyperdiverse phyla of the Asco- and Basidiomycota (Stürmer, Bever, \& Morton, 2018; Tedersoo et al., 2014). In agreement with this notion, we classified only 550 of a total 7003 OTUs, i.e., $7.85 \%$ of the putative fungal species in the root-associated fungal community (RFC) as Glomeromycota (chapter 2.1). They only accounted for $3.96 \%$ of the molecular read abundance in the RFC (chapter 2.1), while most fungi belonged to Asco- and Basisdiomycota (chapter 2.2).Other studies report even lower diversity of AM taxa on similar spatial scales ranging from 140 taxa to numbers as low as 39 (Edy, 2015; Lumini, Orgiazzi, Borriello, Bonfante, \& Bianciotto, 2010; Rodríguez-Echeverría et al., 2017). However, it should be kept in mind that primer choice and the methodology of bioinformatic processing have a strong impact on the results of high throughput sequencing data (Lindahl et al., 2013; Peay, Kennedy, \& Bruns, 2008; Toju, Tanabe, Yamamoto, \& Sato, 2012). The short Illumina sequence reads currently used in most studies, including this thesis, likely overestimate the true diversity of AM fungi. Therefore, direct comparison of microbial diversity between different studies is problematic. However, the results of chapter 2.1. demonstrate drastic effects on low-abundance groups such as AM, which are sensitive to anthropogenic disturbances. This effect remained undetected when analyzing the whole fungal microbiome (chapter 2.2, 
Brinkmann et al., 2019; Grass et al., 2020). Selective negative effects of anthropogenic land-use on the diversity of essential groups such as AM therefore are likely to drive functional turnover of fungal communities.

Strong links between LUI and shifts in the root-associated AM community were demonstrated in chapter 2.1. Those shifts were probably caused by elevated fertilizer inputs in intensively managed plantation sites. Studies with agricultural crops have often shown that nitrogen and phosporus fertilization causes reduction in AM (Liu et al., 2012; Mäder, Edenhofer, Boller, Wiemken, \& Niggli, 2000; Williams, Manoharan, Rosenstock, Olsson, \& Hedlund, 2017; Zhu et al., 2016). AM fungi generally show low host specificity (Davison et al., 2015; Engelmoer \& Kiers, 2015). Here, AM communities in roots of phylogenetically unrelated tree species such as oil palm and rubber showed a stronger overlap than with any forest tree host (Edy, 2015). This result provides circumstantial evidence that LUI and not tree taxonomic diversity loss is a main driver for the AM community composition and abundance. AM fungi contribute significantly to the plants' uptake of phosphorus and nitrogen in soil (Smith \& Read, 2008). Addition of readily available nutrients may lead to the loss of the benefits provided by $A M$ to the host and consequently, impair the mutualistic interaction (Bennett \& Bever, 2009; Treseder, 2004). The results of this thesis are agreement with this concept because structuring effects of soil phosphorus were demonstrated for the mycorrhizal community composition but not for other fungal functional groups (chapter 2.2). First results from a management experiment also support a link between AM levels and fertilizer input because higher AM abundances were detected in plots with reduced fertilizer inputs than in those with conventional management already after one year (Ryadin, personal communication). Reducing fertilizer inputs as a management strategy to moderate LUI may, thus, positively affect the AM community. A diverse AM community benefits plant health and performance (van der Heijden, Bardgett, \& van Straalen, 2008; van der Heijden, Martin, Selosse, \& Sanders, 2015).

High turnover was found between the local root associated fungal community (RFC) and the soil fungal community (SFC) (chapter 2.2). Therefore, one may assume that the assembly of rootassociated fungal communities from the regional species pool occurs largely independently from the local soil fungal pool (Figure 3.1). While the SFC is filtered by edaphic properties, the RFC is subject to a double filtering process, firstly by edaphic conditions and secondly by root traits (Figure 3.1, Vályi, Mardhiah, Rillig, \& Hempel, 2016). A novel result of this thesis was that changes in root traits drove changes in the SFC, though to a lesser degree than abiotic filters (chapter 2.2). Thus, bottom up regulatory effects of root traits, mainly root vitality, may indirectly affect the local SFC via the RFC (Figure 3.1). My study, in agreement with a few previous investigations underpins diverging effects of environmental drivers on fungal communities associated with these two compartments (Goldmann 
et al., 2016; Stevens et al., 2020; Zhao et al., 2019). Moreover, the present results emphasize the need to carefully distinguish between root and soil associated fungal communities, when investigating the relative contribution of structuring drivers because the importance of these drivers differ profoundly in soil and roots and in different ecological groups of fungi.

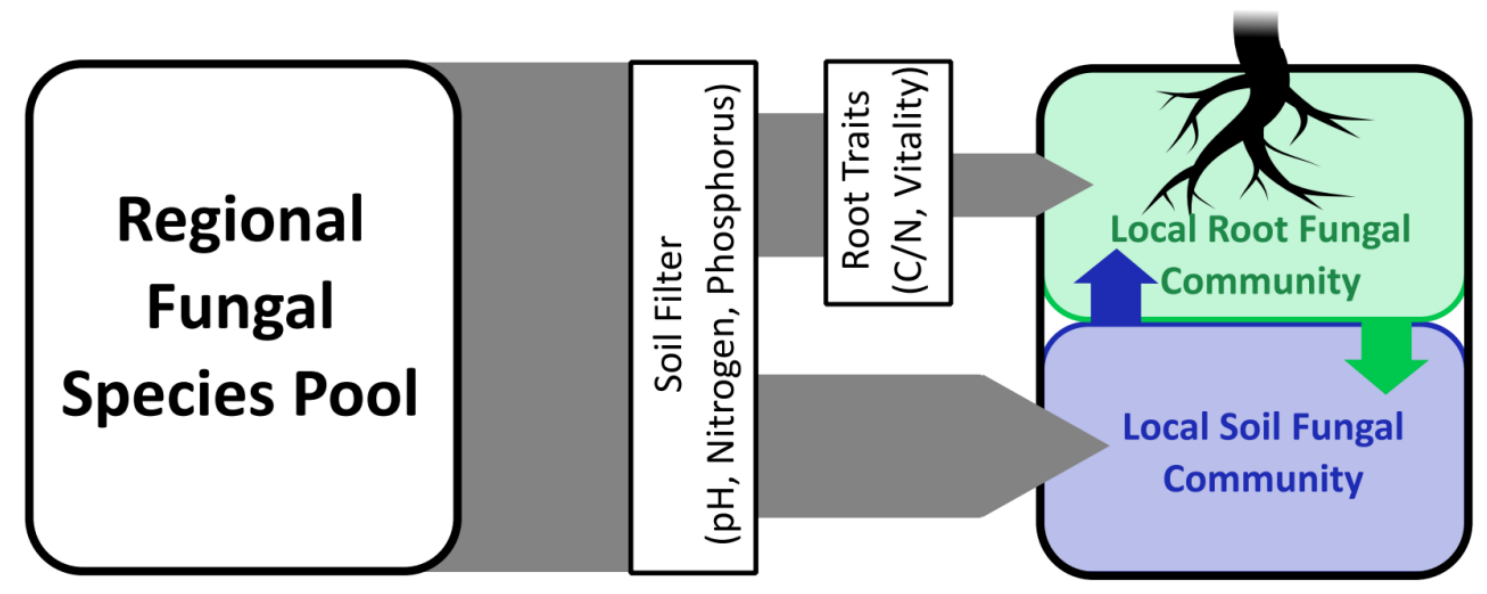

Figure 2.3.1 Conceptual model showing controlling mechanisms of the soil and root associated fungal community assembly under human land-use. Local fungal community assemblies are recruited from the regional species pool (grey arrows) and primarily filtered by edaphic properties. The root fungal community is further structured by root community traits. Both local communities are recruited independently. Spillover effects between them are expected.

Since we found a decline in AM and a strong turnover of soil fungi in different land-use systems (chapter 2.1, 2.2), an important question was whether these patterns can be - at least partly reverted by tree enrichment in islands in conventionally managed oil palm plantations. Structuring effects of tropical agroforestry management on the composition of soil fungal communities have often been demonstrated (Brinkmann et al., 2019; Buyer, Baligar, He, \& Arévalo-Gardini, 2017; Moreira, Celestino, Sobrinho, Cardoso, \& Elliot, 2019). Therefore, I expected that tree enrichment and natural succession might result in diverging fungal community structures and benefit the abundance of mycorrhizal fungi. Disappointingly, no effect of tree diversity, nor the presence of individual tree species or undergrowth plant succession had an effect on the SFC composition. In combination with results from chapter 2.2 that revealed a high turnover for local soil and root communities, I speculate that bottom-up regulatory plant effects could be initiated at the RFC (Figure 3.1). Subsequently, the SFC might be influenced by "spillover effects" of the RFC, however, with a long temporal delay (Figure 3.1). This mechanism could explain the long lasting legacy effect of landuse on soil fungal communities (Bachelot et al., 2016; Chai et al., 2019). It is unclear, at which spatial scale the fungal "spillover" could affect the surrounding SFC. It is conceivable that that the intensive land-use history in oil palm plantations causes massive biotic homogenization of the soil fungal community and strongly favors generalist fungi with a broad ecological niche (Gossner et al., 2016; Mueller et al., 2016). Based on these considerations, time series studies of the turnover of fungal 
communities associated with roots, with the rhizosphere, and the bulk soil are suggested. These studies may contribute to uncover temporal and spatial effects that may hinder or facilitate fungal ecological functions in mixed restoration-cash crop plantation.

\section{Literature}

Baas Becking, L. G. M. (1934). Geobiologie of inleiding tot de milieukunde. Den Haag, Netherlands: Van Stockum and Zoon.

Bachelot, B., Uriarte, M., Zimmerman, J. K., Thompson, J., Leff, J. W., Asiaii, A., Koshner, J., \& McGuire, K. (2016). Long-lasting effects of land use history on soil fungal communities in second-growth tropical rain forests. Ecological Applications, 26(6), 1881-1895. doi: 10.1890/15-1397.1

Beng, K. C., \& Corlett, R. T. (2019). Identifying the mechanisms that shape fungal community and metacommunity patterns in Yunnan, China. Fungal Ecology, 42, 100862. doi: 10.1016/j.funeco.2019.08.006

Bennett, A. E., \& Bever, J. D. (2009). Trade-offs between arbuscular mycorrhizal fungal competitive ability and host growth promotion in Plantago lanceolata. Oecologia, 160(4), 807-816. doi: 10.1007/s00442-0091345-6

Berkelmann, D., Schneider, D., Meryandini, A., \& Daniel, R. (2020). Unravelling the effects of tropical land use conversion on the soil microbiome. Environmental Microbiome, 15(1), 5. doi: 10.1186/s40793-0200353-3

Brinkmann, N., Schneider, D., Sahner, J., Ballauff, J., Edy, N., Barus, H., Irawan, B., Budi, S. W., Qaim, M., Daniel, R., \& Polle, A. (2019). Intensive tropical land use massively shifts soil fungal communities. Scientific Reports, 9(1), 3403. doi: 10.1038/s41598-019-39829-4

Buyer, J. S., Baligar, V. C., He, Z., \& Arévalo-Gardini, E. (2017). Soil microbial communities under cacao agroforestry and cover crop systems in Peru. Applied Soil Ecology, 120, 273-280. doi: 10.1016/j.apsoil.2017.09.009

Chai, Y., Cao, Y., Yue, M., Tian, T., Yin, Q., Dang, H., Quan, J., Ruichang, Z., \& Wang, M. (2019). Soil abiotic properties and plant functional traits mediate associations between soil microbial and plant communities during a secondary forest succession on the Loess Plateau. Frontiers in Microbiology, 10. doi: 10.3389/fmicb.2019.00895

Darras, K. F. A., Corre, M. D., Formaglio, G., Tjoa, A., Potapov, A., Brambach, F., Sibhatu, K. T., Grass, I., Rubiano, A. A., Buchori, D., Drescher, J., Fardiansah, R., Hölscher, D., Irawan, B., Kneib, T., Krashevska, V., Krause, A., Kreft, H., Li, K., Maraun, M., Polle, A., Ryadin, A. R., Rembold, K., Stiegler, C., Scheu, S., Tarigan, S., Valdés-Uribe, A., Yadi, S., Tscharntke, T., \& Veldkamp, E. (2019). Reducing fertilizer and avoiding herbicides in oil palm plantations-ecological and economic valuations. Frontiers in Forests and Global Change, 2. doi: 10.3389/ffgc.2019.00065

Davison, J., Moora, M., Öpik, M., Adholeya, A., Ainsaar, L., Bâ, A., Burla, S., Diedhiou, A. G., Hiiesalu, I., Jairus, T., Johnson, N. C., Kane, A., Koorem, K., Kochar, M., Ndaiye, C., Pärtel, M., Reier, Ü., Saks, Ü., Singh, R., Vasar, M., \& Zobel, M. (2015). Global assessment of arbuscular mycorrhizal fungus diversity reveals very low endemism. Science, 349(6251), 970-973. doi: 10.1126/science.aab1161

Edy, N. (2015). Community structure of arbuscular mycorrhizal fungi in temeprate grassland and tropical landuse systems. Georg-August Universität, Göttingen.

Engelmoer, D. J. P., \& Kiers, E. T. (2015). Host diversity affects the abundance of the extraradical arbuscular mycorrhizal network. New Phytologist, 205(4), 1485-1491. doi: 10.1111/nph.13086

Fuhrman, J. A. (2009). Microbial community structure and its functional implications. Nature, 459(7244), 193199. doi: $10.1038 /$ nature08058

Goldmann, K., Schröter, K., Pena, R., Schöning, I., Schrumpf, M., Buscot, F., Polle, A., \& Wubet, T. (2016). Divergent habitat filtering of root and soil fungal communities in temperate beech forests. Scientific Reports, 6(1). doi: 10.1038/srep31439 
Gossner, M., Lewinsohn, T. M., Kahl, T., , Grassein, F., Boch, S., Prati, D., Birkhofer, K., Renner, S. C., Sikorski, J., Wubet T., Arndt, H., Baumgartner, V., Blaser, S., Blüthgen, N., Börschig, C., Buscot, F., Diekötter, T., Jorge, L. R., Jung, K., Keyel, A. C., Klein, A.-M., Klemmer, S., Krauss, J., Lange, M., Müller, J., Overmann, J., Pašalić, E., Penone, C., Perović, D. J., Purschke, O., Schall, P., Socher, S. A., Sonnemann, I., Tschapka, M., Tscharntke, T., Türke, M., Venter, P. C., Weiner, C. N., Werner, M., Wolters, V., Wurst, S., Westphal, C., Fischer, M., Weisser, W. W., \& Allan, E. (2016). Land-use intensification causes multitrophic homogenization of grassland communities. Nature, 540(7632), 266-269. doi: 10.1038/nature20575

Grass, I., Kubitza, C., Krishna, V. V., Corre, M. D., Mußhoff, O., Pütz, P., Drescher, J., Rembold, K., Ariyanti, E. S., Barnes, A. D., Brinkmann, N., Brose, U., Brümmer, B., Buchori, D., Daniel, R., Darras, K. F. A., Faust, H., Fehrmann, L., Hain, J., Hennings, N., Hidayat, P., Hölscher, D., Jochum, M., Knohl, A., Kotowska, M. M., Krashevska, V., Kreft, H., Leuschner, C., Lobite, N. J. S., Panjaitan, R., Polle, A., Potapov, A. M., Purnama, E., Qaim, M., Röll, A., Scheu, S., Schneider, D., Tjoa, A., Tscharntke, T., Veldkamp, E., \& Wollni, M. (2020). Trade-offs between multifunctionality and profit in tropical smallholder landscapes. Nature Communications, 11(1), 1-13. doi: 10.1038/s41467-020-15013-5

Kerfahi, D., Tripathi, B. M., Dong, K., Go, R., \& Adams, J. M. (2016). Rainforest conversion to rubber plantation may not result in lower soil diversity of bacteria, fungi, and nematodes. Microbial Ecology, 72(2), 359371. doi: 10.1007/s00248-016-0790-0

Kerfahi, D., Tripathi, B. M., Lee, J., Edwards, D. P., \& Adams, J. M. (2014). The impact of selective-logging and forest clearance for oil palm on fungal communities in Borneo. PLOS ONE, 9(11), e111525. doi: 10.1371/journal.pone.0111525

Kivlin, S. N., Winston, G. C., Goulden, M. L., \& Treseder, K. K. (2014). Environmental filtering affects soil fungal community composition more than dispersal limitation at regional scales. Fungal Ecology, 12, 14-25. doi: 10.1016/j.funeco.2014.04.004

Lindahl, B. D., Nilsson, R. H., Tedersoo, L., Abarenkov, K., Carlsen, T., Kjøller, R., Kõljalg, U., Pennanen, T., Rosendahl, S., Stenlid, J., \& Kauserud, H. (2013). Fungal community analysis by high-throughput sequencing of amplified markers-A user's guide. New Phytologist, 199(1), 288-299. doi: 10.1111/nph.12243

Liu, Y., Shi, G., Mao, L., Cheng, G., Jiang, S., Ma, X., An, L., Du, G., Collins Johnson, N., \& Feng, H. (2012). Direct and indirect influences of $8 \mathrm{yr}$ of nitrogen and phosphorus fertilization on Glomeromycota in an alpine meadow ecosystem. The New Phytologist, 194(2), 523-535. doi: 10.1111/j.1469-8137.2012.04050.x

Lumini, E., Orgiazzi, A., Borriello, R., Bonfante, P., \& Bianciotto, V. (2010). Disclosing arbuscular mycorrhizal fungal biodiversity in soil through a land-use gradient using a pyrosequencing approach. Environmental Microbiology, 12(8), 2165-2179. doi: 10.1111/j.1462-2920.2009.02099.x

Mäder, P., Edenhofer, S., Boller, T., Wiemken, A., \& Niggli, U. (2000). Arbuscular mycorrhizae in a long-term field trial comparing low-input (organic, biological) and high-input (conventional) farming systems in a crop rotation. Biology and Fertility of Soils, 31(2), 150-156. doi: 10.1007/s003740050638

McGuire, K. L., D’Angelo, H., Brearley, F. Q., Gedallovich, S. M., Babar, N., Yang, N., Gillikin, C. M.,Gradoville, R., Bateman, C., Turner, B. L., Mansor, P., Leff, J. W., \& Fierer, N. (2015). Responses of soil fungi to logging and oil palm agriculture in Southeast Asian tropical forests. Microbial Ecology, 69(4), 733-747. doi: 10.1007/s00248-014-0468-4

Moreira, C. C., Celestino, D., Sobrinho, T. G., Cardoso, I. M., \& Elliot, S. L. (2019). Agroforestry coffee soils increase the insect-suppressive potential offered by entomopathogenic fungi over full-sun soils: A case proposing a "bait survival technique". Ecology and Evolution, 9(18), 10777-10787. doi: 10.1002/ece3.5598

Mueller, R. C., Paula, F. S., Mirza, B. S., Rodrigues, J. L. M., Nuesslein, K., \& Bohannan, B. J. M. (2014). Links between plant and fungal communities across a deforestation chronosequence in the Amazon rainforest. The ISME Journal, 8, 1548-1550.

Mueller, R. C., Rodrigues, J. L. M., Nüsslein, K., \& Bohannan, B. J. M. (2016). Land use change in the Amazon rain forest favours generalist fungi. Functional Ecology, 30(11), 1845-1853. doi: 10.1111/1365-2435.12651

Peay, K. G., Bidartondo, M. I., \& Arnold, A. E. (2010). Not every fungus is everywhere: Scaling to the biogeography of fungal-plant interactions across roots, shoots and ecosystems. New Phytologist, 185(4), 878-882. doi: 10.1111/j.1469-8137.2009.03158.x 
Peay, K. G., Kennedy, P. G., \& Bruns, T. D. (2008). Fungal community ecology: A hybrid beast with a molecular master. AIBS Bulletin, 58(9), 799-810.

Rodríguez-Echeverría, S., Teixeira, H., Correia, M., Timóteo, S., Heleno, R., Öpik, M., \& Moora, M. (2017). Arbuscular mycorrhizal fungi communities from tropical Africa reveal strong ecological structure. New Phytologist, 213(1), 380-390. doi: 10.1111/nph.14122

Smith, S. E., \& Read, D. (2008). Mycorrhizal symbiosis. doi: 10.1016/B978-0-12-370526-6.X5001-6

Stevens, B. M., Propster, J. R., Öpik, M., Wilson, G. W. T., Alloway, S. L., Mayemba, E., \& Johnson, N. C. (2020). Arbuscular mycorrhizal fungi in roots and soil respond differently to biotic and abiotic factors in the Serengeti. Mycorrhiza. doi: 10.1007/s00572-020-00931-5

Stürmer, S. L., Bever, J. D., \& Morton, J. B. (2018). Biogeography of arbuscular mycorrhizal fungi (Glomeromycota): A phylogenetic perspective on species distribution patterns. Mycorrhiza, 28(7), 587-603. doi: 10.1007/s00572-018-0864-6

Taylor, J. W., Turner, E., Townsend, J. P., Dettman, J. R., \& Jacobson, D. (2006). Eukaryotic microbes, species recognition and the geographic limits of species: Examples from the kingdom Fungi. Philosophical Transactions of the Royal Society B: Biological Sciences, 361(1475), 1947-1963. doi: 10.1098/rstb.2006.1923

Tedersoo L., Bahram, M., , Põlme, S., Kõljalg, U., Yorou, N. S., Wijesundera, R., Ruiz, L. V., Vasco-Palacios, A. M., Thu, P. Q., Suija, A., Smith M. E., Sharp, C., Saluveer, E., Saitta A., Rosas, M., Riit, T., Ratkowsky, D., Pritsch, K., Põldmaa, K., Piepenbring, M., Phosri, C., Peterson, M., Parts, K., Pärtel, K., Otsing, E., Nouhra, E., Njouonkou, A. L, Nilsson, R. H., Morgado, L. N., Mayor, J., May T. W., Majuakim, L., Lodge D. J., Lee, S. S., Larsson K.-H., Kohout, P., Hosaka, K., Hiiesalu I., Henkel, T. W., Harend, H., Guo, L., Greslebin, A., Grelet G., Geml, J., Gates, G., Dunstan, W., Dunk, C., Drenkhan, R., Dearnaley, J., de Kesel, A., Dang T., Chen, X., Buegger F., Brearley, F. Q., Bonito, G., Anslan S., Abell S., Abarenkov K. (2014). Global diversity and geography of soil fungi. Science, 346(6213), 1256688-1256688. doi: 10.1126/science. 1256688

Toju, H., Tanabe, A. S., Yamamoto, S., \& Sato, H. (2012). High-coverage ITS primers for the DNA-based identification of Ascomycetes and Basidiomycetes in environmental samples. PLoS ONE, 7(7), e40863. doi: 10.1371/journal.pone.0040863

Treseder, K. K. (2004). A meta-analysis of mycorrhizal responses to nitrogen, phosphorus, and atmospheric CO2 in field studies. New Phytologist, 164(2), 347-355. doi: 10.1111/j.1469-8137.2004.01159.x

Vályi, K., Mardhiah, U., Rillig, M. C., \& Hempel, S. (2016). Community assembly and coexistence in communities of arbuscular mycorrhizal fungi. The ISME Journal, 10(10), 2341-2351. doi: 10.1038/ismej.2016.46

van der Heijden, M. G. A., Bardgett, R. D., \& van Straalen, N. M. (2008). The unseen majority: Soil microbes as drivers of plant diversity and productivity in terrestrial ecosystems. Ecology Letters, 11(3), 296-310. doi: 10.1111/j.1461-0248.2007.01139.x

van der Heijden, M. G. A. van der, Martin, F. M., Selosse, M.-A., \& Sanders, I. R. (2015). Mycorrhizal ecology and evolution: The past, the present, and the future. New Phytologist, 205(4), 1406-1423. doi: 10.1111/nph.13288

Williams, A., Manoharan, L., Rosenstock, N. P., Olsson, P. A., \& Hedlund, K. (2017). Long-term agricultural fertilization alters arbuscular mycorrhizal fungal community composition and barley (Hordeum vulgare) mycorrhizal carbon and phosphorus exchange. New Phytologist, 213(2), 874-885. doi: 10.1111/nph.14196

Zhao, J., Gao, Q., Zhou, J., Wang, M., Liang, Y., Sun, B., Chu, H., \& Yang, Y. (2019). The scale dependence of fungal community distribution in paddy soil driven by stochastic and deterministic processes. Fungal Ecology, 42, 100856. doi: 10.1016/j.funeco.2019.07.010

Zhu, C., Ling, N., Guo, J., Wang, M., Guo, S., \& Shen, Q. (2016). Impacts of fertilization regimes on arbuscular mycorrhizal fungal (AMF) community composition were correlated with organic matter composition in maize rhizosphere soil. Frontiers in Microbiology, 7. doi: 10.3389/fmicb.2016.01840 


\section{Acknowledgements}

Firstly I would like to thank my supervisor Prof. Dr. Andrea Polle for her continuous support, trust and valuable advice. Without her input this thesis would not have been possible. I would also like to thank my second supervisor Prof. Dr.Stefan Scheu, who is also doing an outstanding job as the head and speaker of the EFForTS project, now continuing the project to its third phase. Many thanks to all members of the examination board: Prof. Dr. Rolf Daniel, Prof. Dr. Oliver Gailing, Prof. Dr. Christian Ammer and Prof. Dr. Christoph Leuschner.

This thesis was made possible with the help of many people. I would like to give a special thanks to Dr. Dominik Schneider who conducted the bioinformatic processing and contributed reliable and helpful advice.

My thanks goes to all members of the department of Forest Botany and Tree Physiology (University of Goettingen) for many wonderful coffee breaks, occasional after-work beers and all-around creating an outstanding working environment. You are great colleagues! Namely I would like to mention Thomas Klein and Monika Franke-Klein for their excellent support and advice in the lab, Dr. Denis Janz (PhD, University of Göttingen) who motivated me to extend my knowledge on statistical analysis and $\mathrm{R}$ as well as Dr. Nicole Brinkmann for many fruitful discussions. Thanks to Karl Kasper who supported me with $\mathrm{CN}$ analysis and Aisjah Ryadin, who conducted the staining of the root samples.

My gratitude goes to all people involve in the EFForTS project. I thank our counterparts in Indonesia, Dr. Bambang Irawan, Dr. Sri Wilarso Budi, Dr. Henry Barus, Dr. Nur Edy and Dr. Upik Yelanti for their support in the field work and helping to overcome administrative boundaries. My sincerest thanks also to Aiyen Tjoa, who managed the sample export permission. I would like to mention the great work done by the administrative staff in Indonesia and Germany: Dr. Barbara Wick, Ivonne Hein, Rizky Febrianty Megawati Syafni, Yuking Linatra and Indri Hapsari Fitriyani. Last but not least I thank all the Ph.D. students and post-docs whom I shared time with during four month of field work in Indonesia. It is thanks to you guys that this time was one of my greatest experiences!

Finally I also would like to thank the Deutsche Forschungsgemeinschat (DFG) for funding this project (B07, CRC990). 


\section{Appendix 1: Sampling and export Permission}

\section{Sampling 2013}

Research permit (Kartu Izin Peneliti Asing, permission number: 333/ SIP/ FRP/ SM/ IX/ 2012) was issued by the Ministry of Research and Technology RISTEK (Kementrian Ristek dan Teknologi, Jakarta, Indonesia). The Research Center for Biology of the Indonesian Institute of Science LIPI (Lembaga IImu Pengetahuan Indonesia, Jakarta, Indonesia) recommended issuing a sample collection permit (Rekomendasi ljin Pengambilan dan Angkut (SAT- DN) Sampel Tanah dan Akar, number: 2696/ IPH.1/ KS:02/ XI/ 2012). Collection permit (number: S.16/KKH- 2/ 2013) and export permit (reference number: 48/KKH- 5/ TRP/ 2014) were issued by the Directorate General of Forest Protection and Nature Conservation PHKA (Perlindungan Hutan dan Konservasi Alam, Jakarta, Indonesia) under the Ministry of Forestry of the Republic of Indonesia. The Chamber of Agriculture of Lower Saxony (Plant Protection Office, Hannover, Germany) issued the import permits (Letter of Authority, numbers: DE DE-NI-17-03 2008 -61-EC).

\section{Sampling 2016}

Research permit (Surat Izin Penelitian, reference number: 328/ SIP/FRP/E5/Dit.KI/IX/2016) was issued by the Ministry of Research Technology and Higher Education (Kementrian Riset, Teknologi dan Pendidikan Tinggi, Jakarta, Indonesia). The permit recommendations for sample collection, domestic sample transport, sample export and access to the genetic material were issued by the Research Center for Biology of the Indonesian Institute of Science (Lembaga Ilmu Pengetahuan Indonesia, Jakarta, Indonesia) number: 2781/ IPH.1/ KS.02.04/IX/2016 and B1345/IPH.1/KS.02.04/III/2019.

The permit for sample collection, domestic sample transport, sample export and access to the genetic material was issuedby the Ministry of Environment and Forestry, Directorate General of Conservation of Natural Resources and Ecosystems of the Republic of Indonesia (Izin akses sumber daya genetik untuk kepentingan penelitian oleh Kementerian Lingkungan Hidup dan Kehutanan, Direktorat Jenderal Konservasi Sumber Daya Alam dan Ekosistem) number S.1068/KKH/SDG/KSA.2/11/2016 and SK.335/KSDAE/SET/KSA.2/7/2019.

The Chamber of Agriculture of Lower Saxony (Plant Protection Office, Hannover, Germany) issued the import permits (Letter of Authority, numbers: DE-NI-17-03 2008 -61-EC). 


\section{Appendix 2: Intensive tropical land use massively shifts soil fungal communities}

Nicole Brinkmann ${ }^{1, \#, *}$, Dominik Schneider ${ }^{2, \#}$, Josephine Sahner $^{1}$, Johannes Ballauff ${ }^{1}$, Nur Edy $^{1,3}$, Henry Barus ${ }^{3}$, Bambang Irawan ${ }^{4}$, Sri Wilarso Budi ${ }^{5}$, Matin Qaim ${ }^{6}$, Rolf Daniel ${ }^{2}$, Andrea Polle ${ }^{1}$

${ }^{1}$ Forest Botany and Tree Physiology, University of Goettingen, Germany, ${ }^{2}$ Genomic and Applied Microbiology and Göttingen Genomics Laboratory, University of Goettingen, Germany, ${ }^{3}$ Department of Agrotechnology, Faculty of Agriculture, Tadulako University, Indonesia, ${ }^{4}$ Department of Forestry, University of Jambi, Indonesia, ${ }^{5}$ Department of Silviculture, Faculty of Forestry, Bogor Agriculture University, Bogor, Indonesia, ${ }^{6}$ Department of Agricultural Economics and Rural Development, University of Goettingen, Germany

${ }^{\#}$ These authors contributed equally to this work

*Correspondence: Nicole Brinkmann, Forest Botany and Tree Physiology, University of Goettingen, Büsgenweg 2, 37077 Goettingen, Germany, nbrinkm3@gwdg.de, Tel.: +49 551 39 9745, Fax: +495513922705

Published in Scientific Reports Vol. 9, 2019

The authors declare no conflict of interest 


\section{Abstract}

Soil fungi are key players in nutrient cycles as decomposers, mutualists and pathogens, but the impact of tropical rain forest transformation into rubber or oil palm plantations on fungal community structures and their ecological functions are unknown. We hypothesized that increasing land use intensity and habitat loss due to the replacement of the hyperdiverse forest flora by nonendemic cash crops drives a drastic loss of diversity of soil fungal taxa and impairs the ecological soil functions. Unexpectedly, rain forest conversion was not associated with strong diversity loss but with massive shifts in soil fungal community composition. Fungal communities clustered according to land use system and loss of plant species. Network analysis revealed characteristic fungal genera significantly associated with different land use systems. Shifts in soil fungal community structure were particularly distinct among different trophic groups, with substantial decreases in symbiotrophic fungi and increases in saprotrophic and pathotrophic fungi in oil palm and rubber plantations in comparison with rain forests. In conclusion, conversion of rain forests and current land use systems restructure soil fungal communities towards enhanced pathogen pressure and, thus, threaten ecosystem health functions. 


\section{Introduction}

Tropical rain forests are the planet's most species-rich biomes ${ }^{1}$. In the past two decades, tropical rain forests in many parts of the world have been rapidly converted to monospecific plantations ${ }^{2}$. As a result, deforestation and human land use have irretrievably destroyed large areas of unique rain forests and enforced biodiversity loss ${ }^{3,4}$. High plant diversities are associated with active, abundant and diverse fungal communities ${ }^{5-7}$. Plant diversity was, therefore, predicted to be a strong driver of fungal species richness in soils of tropical rain forests ${ }^{7-9}$. However, the consequences of rain forest transformation into agricultural land for soil fungal diversity and the ecological functions of these fungi are not well understood.

Soil fungi are integral components of ecosystems, driving nutrient cycling as decomposers ${ }^{10-}$ ${ }^{13}$, regulating species composition as pathogens ${ }^{14}$ and providing mutualistic benefits as symbiotrophs, thereby playing a key role in biogeochemical processes ${ }^{15,16}$ and in soil health 17,18. Because of their important functions, the impact of deforestation and land use intensification on soil fungal communities in the tropics is receiving increasing attention. To date, only a few studies have used next-generation sequencing methods to characterize soil fungal communities after the conversion of rain forests into agricultural land ${ }^{19-22}$. Those studies focused mainly on distinct fungal groups such as mycorrhizae and the turnover of their community structure in response to distinct land use systems such as the conversion of rain forest into pasture or cash crop plantations with oil palms or rubber trees ${ }^{19-22}$. However, approaches linking land use systems or aboveground vegetation diversity with soil fungal richness and diversity are rare ${ }^{23}$. To better understand the consequences of forest conversion for the taxonomic and functional composition of soil fungi, studies across different landscapes in relation to land use systems and plant diversity loss are required. Such approaches are urgently needed for recommendations for sustainable land use ${ }^{24}$. 
Here, we investigated the impact of land use systems and loss of plant richness on soil fungal diversity in southeast Asia, where natural forests are transformed into cash crop plantations at unprecedented rates ${ }^{25,26}$. Loss of natural forest resources is particularly strong in Indonesia, which is currently the world's largest palm oil producer ${ }^{27}$ and is second in rubber production ${ }^{28}$. We conducted our study in two regions in Sumatra (Indonesia), selecting unmanaged lowland rain forests, moderately managed jungle rubber agroforests and intensively managed plantations, where oil palm (Elaeis guineensis Jacq.) or rubber (Hevea brasiliensis Kunth. Muell.) were the only tree species. Oil palm and rubber plantations are fertilized with 300 to $600 \mathrm{~kg} \mathrm{ha}^{-1} \mathrm{yr}^{-1}$ and 100 to $300 \mathrm{~kg} \mathrm{ha}^{-1} \mathrm{yr}^{-1}$ inorganic NPK fertilizer, respectively. Other inputs are cow dung and lime, in addition to herbicide treatments twice a year ${ }^{29}$. We used these inputs and planting intensities to calculate indices for land use intensity. Previous investigations in our study regions showed that plant species richness and above- and belowground plant biomass are reduced in oil palm and rubber plantations compared with rain forests ${ }^{4,30}$. We expected that the replacement of the hyperdiverse forest flora by nonendemic oil palm and rubber trees resulted in drastic diversity losses of soil fungal taxa because plant communities structure soil habitats ${ }^{31-33}$. We used vegetation richness and indicators of land use to test the hypothesis that soil fungal species richness is driven by land use intensity ${ }^{34}$ and by loss of plant species richness. We further tested the hypothesis that intensive land use in monospecific plantations leads to changes in the ecological functions of soil fungi. To investigate this proposition, we categorized soil fungi according to their trophic mode into guilds (symbiotrophic, pathotrophic and saprotrophic), studied shifts in the composition of the ecological fungal groups and employed network analyses to uncover indicator fungi for different land use systems. 


\section{Materials and methods}

\section{Study sites and sampling design}

The study sites were located in two different landscapes (Harapan Rain Forest, National Park Bukit 12) in the Jambi Province of Sumatra, Indonesia. Both landscapes have been previously described based on latitude and longitude, soil type, climate, rainfall, annual precipitation, temperature and vegetation ${ }^{33,35-37}$. Details of our sampling design have been described by Sahner et al. ${ }^{33}$. In brief, in each landscape, four land use systems (secondary rain forest, rubber agroforest (jungle rubber), rubber plantations and oil palm plantations) were selected. In each land use system, four plots $(50 \mathrm{~m} \times 50 \mathrm{~m})$ were installed, resulting in a total of 32 sampling plots. In each plot, three subplots of $5 \mathrm{~m} \times 5 \mathrm{~m}$ were selected. To account for heterogeneity, in each subplot five soil cores (0.04 m diameter and $0.20 \mathrm{~m}$ depth) were extracted (one close to each corner and one in the center of the subplot). Soil cores were stored individually in plastic bags that were then stored in cool bags and transported to the University of Jambi, where they were stored at $4^{\circ} \mathrm{C}$ until further processing. Each soil core was weighed and consecutively sieved through two sieves with 10 and $5 \mathrm{~mm}$ mesh size, and bulk soil was separated from roots. The five samples from the same subplot were pooled and well mixed, yielding one bulk soil sample per subplot ${ }^{33}$. To freeze dry the bulk soil samples, the reaction tubes (50 ml, Sarstedt, Nümbrecht, Germany) containing bulk soil were opened, and gauze was put into the aperture of each tube to avoid loss of bulk soil during freeze drying. Reaction tubes containing bulk soil were put on a rack and placed in a $80{ }^{\circ} \mathrm{C}$ freezer for at least 3 hours before freeze drying to make sure that the bulk soil had a sufficiently low temperature. Freeze drying was performed using a VirTis Benchtop K Freeze Dryer (SP Industries, Warminster, USA) with a dual stage rotary vane vacuum pump (Trivac E2, Leybold Vakuum GmbH, Köln, Germany) for approximately 32 hours. Afterwards, three perforated Eppendorf tubes filled with $5 \mathrm{~g}$ of silica gel (desiccant bag of silica gel orange (10 
$\mathrm{g}(40 \times 90 \mathrm{~mm}))$, Carl Roth, Karlsruhe, Germany) were put into the reaction tubes to keep the soil samples dry. The freeze-dried bulk soil samples were shipped to the University of Göttingen. A research permit (Kartu Izin Peneliti Asing, permission number: 333/SIP/FRP/SM/IX/2012) was issued by the Ministry of Research and Technology RISTEK (Kementrian Ristek dan Teknologi, Jakarta, Indonesia). The Research Center for Biology of the Indonesian Institute of Science LIPI (Lembaga IImu Pengetahuan Indonesia, Jakarta, Indonesia) recommended issuing a sample collection permit (Rekomendasi ljin Pengambilan dan Angkut (SAT-DN) Sampel Tanah dan Akar, number: 2696/IPH.1/KS:02/XI/2012). The collection permit (number: S.16/KKH-2/2013) and export permit (reference number: 48/KKH-5/TRP/2014) were issued by the Directorate General of Forest Protection and Nature Conservation PHKA (Perlindungan Hutan dan Konservasi Alam, Jakarta, Indonesia) under the Ministry of Forestry of the Republic of Indonesia. The Chamber of Agriculture of Lower Saxony (Plant Protection Office, Hannover, Germany) issued the import permits (Letter of Authority, numbers: DE-NI-12-69 -2008-61-EC, DE-NI-14-08-2008-61-EC).

\section{Fungal community analysis}

The freeze-dried soil samples were stored at $-20^{\circ} \mathrm{C}$. They were homogenized in a Type MM400 ball mill (Retsch $\mathrm{GmbH}$, Haan, Germany) in liquid nitrogen. DNA isolations were conducted using $250 \mathrm{mg}$ soil, which was further homogenized with glass beads (MO BIO Laboratories Inc., Carlsbad, USA) and used for DNA extraction with a PowerSoil $^{\circledR}$ DNA Isolation Kit (MO BIO Laboratories Inc.), following the manufacturer's recommendations. DNA yields were estimated by using a NanoDrop ND-1000 spectrophotometer (PEQLAB Biotechnologie $\mathrm{GmbH}$, Erlangen, Germany). For each DNA extraction, polymerase chain reaction (PCR) was performed in a $50 \mu \mathrm{l}$ reaction using $0.5 \mu \mathrm{l}$ of Phusion High-Fidelity DNA Polymerase ( $2 \mathrm{U} / \mu \mathrm{l}$, New England Biolabs (NEB), Frankfurt, Germany), $10 \mu \mathrm{l}$ of 5x Phusion GC 
buffer (NEB), $0.15 \mu \mathrm{l}$ of $\mathrm{MgCl}_{2}(50 \mathrm{mM}, \mathrm{NEB}), 2.5 \mu \mathrm{l}$ of DMSO (5 \%, NEB), $2.5 \mu \mathrm{l}$ of bovine serum albumin ( $8 \mathrm{mg} / \mathrm{ml}$, Merck KGaA, Darmstadt, Germany), $1 \mu \mathrm{l}$ of dNTP mix (10 mM each, Thermo Fisher Scientific, Osterode am Harz, Germany), $1 \mu \mathrm{l}$ of each primer $(10 \mathrm{mmol} / \mathrm{l}$, Microsynth, Wolfurt, Austria) and $5 \mu$ of template DNA. PCR reactions were performed in a Labcycler (SensoQuest, Göttingen, Germany). The cycling parameters were 1 cycle of $98^{\circ} \mathrm{C}$ for $3 \mathrm{~min}$; 25 cycles of $98^{\circ} \mathrm{C}$ for $10 \mathrm{~s}, 47^{\circ} \mathrm{C}$ for $20 \mathrm{~s}$ and $72^{\circ} \mathrm{C}$ for $20 \mathrm{~s}$; and a final extension at $72^{\circ} \mathrm{C}$ for $5 \mathrm{~min}$. The primers ITS1-F_KYO1 ${ }^{38}$ and ITS4 ${ }^{39}$ including the Roche 454 pyrosequencing adaptors (Roche, Mannheim, Germany), a key (TCAG), and a variable multiplex identifier (MID) consisting of ten bases were used for amplification of the ITS 1 and 2 regions. PCR products were subjected to electrophoresis in $1.2 \%$ agarose gels (Biozym LE Agarose, Biozym Scientific GmbH, Hessisch Oldendorf, Germany) using GelRed (10 000 x) to stain (VWR, Darmstadt, Germany) a $1 \mathrm{~kb}$ DNA ladder (NEB) for estimation of the product size. PCR products were visualized with an FLA-5100 Fluorescence Laser Scanner (Raytest GmbH, Straubenhardt, Germany) and Aida Image Analyser v. 4.27 (Raytest GmbH). All PCR reactions were performed in triplicate, pooled and purified using an innuPREP PCRpure Kit (Analytik Jena, Jena, Germany). Purified, pooled PCR products were run on an agarose gel and cut in the range of $700-800$ base pairs on a UV table (INTAS UV System type N80M, Göttingen, Germany). A QIAquick Gel extraction kit (Qiagen GmbH, Hilden, Germany) was used for DNA extraction following the manufacturer's recommendations; each sample was eluted in $20 \mu \mathrm{l}$ of nuclease-free water (AppliChem, Darmstadt, Germany). Quantification of purified PCR products was performed using a Quant-iT dsDNA HS assay kit (Life Technologies GmbH, Darmstadt, Germany) in a Qubit fluorometer (Life Technologies GmbH, Darmstadt, Germany) following the manufacturer's recommendations. The Göttingen Genomics Laboratory (G2L) determined the sequences of ITS amplicons by using a 454 GS-FLX 
sequencer (Roche, Mannheim, Germany) and Titanium chemistry following the instructions of the manufacturer for amplicon sequencing.

\section{Sequence processing}

The resulting ITS sequence datasets were quality filtered and primer clipped by employing split_libraries.py from the QIIME 1.9.1 software package ${ }^{40}$. In brief, sequences with lengths below 300 and over $1000 \mathrm{bp}$, quality scores below 25 and homopolymer stretches of more than 8 bp were removed. An additional primer clipping was performed with cutadapt $v 1.6^{41}$. Pyrosequencing noise was removed by employing Acacia v1.53 ${ }^{42}$ with default settings. Highquality reads were further processed with USEARCH (version 8.0.1623_i86linux64) ${ }^{43}$, which included steps in the following order: reference-based removal of chimeric sequences against the unite database (v7.0, sh_refs_qiime_ver7_99_s_01.08.2015.fasta) ${ }^{44}$, sequence sorting by length and singleton removal, OTU determination at $97 \%$ sequence identity (pick_open_reference_otus.py) employing the unite database. Taxonomic classification of OTU sequences was inferred with parallel_assign_taxonomy_blast.py against the UNITE database (v7, sh_refs_qiime_ver7_99_s_01.08.2015.fasta) ${ }^{44,45}$. Taxonomic information was added to the OTU table with make_otu_table.py (QIIME) ${ }^{46}$. Unclassified OTUs and extrinsic domain OTUs (Protista, Plantae) were removed from the table by employing filter_otu_table.py in QIIME. Raw sequences for the resulting fungal OTUs were deposited in the National Center for Biotechnology Information (NCBI) Sequence Read Archive (SRA) under accession number SRP134264 (Bioproject number PRJNA437389). Sampling effort was

controlled by rarefaction analysis (Supplementary data S1) by employing alpha_rarefaction.py. Fungal OTUs were assigned to ecological guilds with the annotation tool FUNGuild ${ }^{47}$, located at https://github.com/UMNFuN/FUNGuild. Here, fungi were 
grouped according to trophic modes: saprotrophic, pathotrophic and symbiotrophic fungi, while fungal sequences without assignment were labeled 'unknown' in further analyses ${ }^{40}$.

\section{Statistical analysis}

Sample comparisons were performed for the same surveying effort using rarefied data sets of 1229 sequences representing the lowest number of reads in a sample. Diversity estimates (OTU richness, Michaelis Menten fit, Chao1, Shannon, Simpson) and rarefaction curves were generated by employing the alpha_rarefaction.py. script in QIIME ${ }^{40}$. Differences among land use systems were analyzed by linear mixed effect models with the Imer function of the multcomp package ${ }^{48}$ in $R$ ( $R$ Core Team, 2015), because the data follow a Gaussian distribution. Generalized mixed effect models with landscape as a random effect were used with the glmer function of the multcomp package to investigate differences in fungal $\alpha$ diversity among land use systems. For displaying the most abundant fungal species all unidentified fungal OTUs were removed and a heatmap was created with ampvis2 ${ }^{49}$, color scale of abundance was square rooted to better visualize low abundant species. Nonmetric multidimensional scaling (NMDS) of fungal communities was conducted in R using the vegan package ${ }^{50}$, based on weighted UniFrac ${ }^{51}$ distance matrices, and used envfit (vegan) to correlate the following explanatory variables: root performance traits (biomass of fine roots, distorted root tips) ${ }^{33}$, plant properties (plant biomass, plant species) ${ }^{4}$, soil properties (soil pH value; soil moisture; and concentrations of magnesium, potassium, carbon, nitrogen, calcium, and available phosphorous ${ }^{32,34}$, litter properties (concentration of carbon and nitrogen) ${ }^{33}$, diversity index (number of OTUs), and land use (land use intensity, LUI) ${ }^{33}$ with the fungal community. The index for tropical land use intensity was developed according to the method of Blüthgen et al. ${ }^{52}$. The land use index (LUI) was calculated separately for each landscape, where each component of land treatment was standardized relative to its mean: 
$=\sqrt{\frac{F 1_{i}}{F 1_{L}}+\frac{F 2_{i}}{F 2_{L}}+\frac{F 3_{i}}{F 3_{L}}+\frac{F 4_{i}}{F 4_{L}}+\frac{F 5_{i}}{F 5_{L}}+\frac{F 6_{i}}{F 6_{L}}+\frac{F 7_{i}}{F 7_{L}}+\frac{H 1_{i}}{H 1_{L}}+\frac{H 2_{i}}{H 2_{L}}+\frac{H 3_{i}}{H 3_{L}}+\frac{H 4_{i}}{H 4_{L}}+\frac{S_{i}}{S_{L}}+\frac{A A_{i}}{A_{L}}+\frac{P 1_{i}}{P 1_{L}}+\frac{P 2_{i}}{P 2_{L_{L}}}}$

with $F_{L}, H_{L}, S_{L}, A_{L}$ and $P_{L}$ being the treatment means. The quantities (kg year ${ }^{-1}$, $L$ year ${ }^{-1}$ ) of fertilizers (F1: urea, F2: potassium chloride, F3: borate, F4: nitrogen-phosphorus-potassium, F5: triple superphosphate, F6: 36 \% superphosphate (SP 36), F7: kieserite), herbicides (H1: Gramaxon, H2: Noxone, H3: Roundup, H4: Ally), animal manure (A1: cow compost), and liming $\left(\mathrm{S} 1: \mathrm{CaCO}_{3}\right)$ applied to the study plots were obtained on the basis of interviews of farmers ${ }^{34,53}$. Planting intensity (P1: rubber, $\mathrm{P} 2$ : oil palm) was quantified as the number of planted trees hectare ${ }^{-1}$. Data for numbers of plant taxa and individuals were obtained from Rembold et al. ${ }^{37}$.

The package "indicspecies" in R was used to identify fungal genera, which are significantly associated with different land use systems ${ }^{54}$. These fungal genera are defined as "indicator species" for a given land use system. The point biserial correlation coefficient was calculated for all identified genera and all taxa with significant $(p \leq 0.05)$ associations were visualized in the network. Networks were generated using the land use systems as source nodes and the associated fungal taxa as nodes, with edges corresponding to positive associations of particular taxa with specific land use systems. Networks were generated using the edge-weighted spring-embedded layout algorithm in Cytoscape 3.5.1 with edges weighted according to the association strength ${ }^{55}$. The network permits visual inspection of the strength of the connection of a fungal taxon (thickness of edges) with and its abundance (size of nodes) in a given land use type. Fungal taxa, which occur across different land use types, are connected by edges, illustrating the extent of overlap. Detailed information how to visually interpret biological data using networks is given by Merico et al. ${ }^{56}$. 


\section{Results}

\section{Changes in land use shift soil fungal communities}

Soil fungi were represented by 293240 high-quality sequences obtained after 454 sequencing and quality filtering. After the removal of singletons and rarefying, 4553 operational taxonomic units (OTUs) at $97 \%$ similarity represented soil fungi in this study (Supplementary data S2a, S2b). Based on the quality-filtered sequences, the observed fungal OTU richness, calculated richness (Michaelis-Menten Fit) and Shannon diversity were highest in the jungle rubber and lowest in the rain forest (Table 1). Fungal OTU richness was driven neither by LUI nor by any other of the tested potential explanatory variables (Supplementary data S3). Chao1 and the Simpson index showed no differences among the land use systems (Table 1).

Land use (goodness of fit $R^{2}=0.8191, p=0.001$, using landscape as an additional factor; or goodness of fit $R^{2}=0.6503, p=0.001$, ignoring landscape) had a significant influence on soil fungal community composition, while landscape alone had no significant influence (goodness of fit $R^{2}=0.0555, p=0.236$ ). Nonmetric multidimensional scaling (NMDS, Figure 1) clearly separated fungal communities according to taxonomic dissimilarities. We detected four fungal clusters distributed along a gradient from unmanaged rain forest and less managed jungle rubber soils to highly managed soils of oil palm and rubber plantations (nonmetric fit, $\mathrm{R}^{2}=0.977$; linear fit, $\mathrm{R}^{2}=0.909$ ). To elucidate the drivers of the gradient in fungal dissimilarities, we fitted sixteen environmental variables (Supplementary data S3), of which six were significantly related to fungal dissimilarities: land use intensity $\left(R^{2}=0.4707, p\right.$ $=0.001)$, plant biomass $\left(R^{2}=0.8181, p=0.001\right)$, plant species richness $\left(R^{2}=0.8218, p=\right.$ $0.001)$, biomass of fine roots $\left(R^{2}=0.4014, p=0.003\right)$, litter carbon concentration $\left(R^{2}=\right.$ 0.3978, $p=0.006)$, and soil $p H\left(R^{2}=0.2968, p=0.012\right)$ (Figure 1$)$. 


\section{Fungal trophic modes significantly differ among land use systems}

FUNGuild classified approximately $60 \%$ of the fungal OTUs according to their trophic mode. The majority of classified fungi were assigned to the group of saprotrophs (70\%); $24 \%$, to pathotrophs; and $6 \%$, to symbiotrophs. Trophic modes differed among the land use systems: symbiotrophic fungi $(p \leq 2.2 e-16)$ showed a maximum relative abundance in rain forests and a minimum in rubber plantations, pathotrophic fungi $(p=8.214 e-14)$ showed the highest abundance in jungle rubber and lowest in the rain forest, and saprotrophs $(p \leq 2.2 e-$ 16) exhibited the highest abundance in oil palm plantations and lowest in the jungle rubber (Figure 2).

\section{Different land use systems are characterized by shifts in fungal taxonomy}

Five fungal phyla were detected across all samples. The phylum Ascomycota showed the highest relative abundance across all land use systems, with a maximum in oil palm plantations and a minimum in jungle rubber plantations $(p<2.2 e-16)$ (Table 2$)$. This phylum harbored most of the abundant fungal taxa and showed increases in abundance in the order of Pleosporales and Sordariales and decreases in the order of Eurotiales (Supplementary data S4, Figure 3). The phylum Basidiomycota had the second highest relative abundance across all land use systems, and their abundances differed among all land use systems $(p=$ 3.96e-4), with a minimum in oil palm plantations and a maximum in rain forests (Table 2 ). Decreases were prevalent in the orders of Tremellales and Trichosporonales in oil palm plantations compared with rain forest (Figure 3). Furthermore, the abundance of Agaricales, which harbor many ectomycorrhizal fungi, also declined between rainforest and oil palm plantations (Figure 3). The Glomeromycota $(p=0.0072)$ were significantly enriched in jungle rubber systems compared to other land use systems (Table 2). Chytridiomycota and Zygomycota were scarce (Table 2). 


\section{Different land use systems harbor distinct indicator fungi}

An association network analysis demonstrated that, of the 590 fungal genera detected in this study, 74 exhibited characteristic associations $(p<0.05)$ with distinct land use systems (Figure 4, Supplementary data S5). In accordance with other studies using this approach, the identified fungal genera were defined as indicator species ${ }^{57,58}$. Among those genera, only 13 $\%$ were associated with two or three land use systems, and not one was shared between rain forests and the managed monospecies plantations (Supplementary data S5). Rain forests were characterized by members of the order Hypocreales $(p=0.002)$ and the family Cordycipitaceae $(p=0.003)$. Jungle rubber and rubber plantations were characterized by an enhanced abundance of members of the genus Trichoderma $(p=0.02)$. Rubber plantations were distinguished by an increased abundance of members of the genus Penicillium $(p=$ 0.003 ), and oil palm plantations, by an enrichment of members of the genus Fusarium ( $p=$ 0.001).

\section{Discussion}

In contrast to our initial hypothesis, rain forest transformation into intensely managed oil palm and rubber monocultures did not result in a drastic loss of soil fungal species. Only marginal differences between land use systems were detected. Here, jungle rubber agroforests, representing moderately disturbed secondary rain forests due to the introduction of rubber trees, exhibited the highest OTU richness. This finding is in agreement with the intermediate disturbance hypothesis, which proposes that the highest diversities will occur in ecological systems with moderate disturbances ${ }^{59}$. Furthermore, earlier studies

${ }^{60}$ found that the same jungle rubber plots studied here also contained the highest amounts of fungal-derived fatty acids thereby supporting enhanced fungal abundance in those systems. Despite drastic decreases in plant species richness and biomass on our study sites 
4,30, bacterial diversity was not significantly decreased in oil palm and rubber plantations compared to rain forests ${ }^{60,61}$. However, the composition of bacterial communities was changed in response to land use changes ${ }^{60}$. For example, nitrogen-fixing Burkholderia (Betaproteobacteria) species as well as ammonia-oxidizing bacteria increased in plantations, most likely due to the use of fertilizers ${ }^{60}$. Furthermore, members of the Bacteroidetes, i.e., uncultured Chitinophagaceae, known as chitin degraders, were also slightly more abundant in managed systems than in rain forests ${ }^{60}$. Here, we found that the taxonomic structures of fungal communities were also massively affected by land use systems. Compositional shifts in fungal communities with a decrease of Basidiomycota and an increase of Ascomycota in agricultural transformation systems in comparison to rain forests were also detected in other studies ${ }^{19-21}$. In our study, the decline in Basidiomycota was underpinned by decreased abundances of Tremellales and Agaricales on the one hand and increases of Pleosporales and Sordariales in the phylum of Ascomycota. Apparently, human interference created new habitats ${ }^{62}$ that were colonized by fungal communities divergent from those in rain forest soil. The main drivers of these changes were the loss of plant diversity, plant biomass, increasing soil $\mathrm{pH}$ and increasing land use intensity. Notably, other factors tested here such as soil nutrient availability and the enrichment of potentially toxic elements in roots such as aluminum ${ }^{63}$ or iron ${ }^{33}$ had no effect on soil fungal community composition. At variance with our findings, fungal richness declined in tropical forests in Panama, probably as the result of long-term $\mathrm{N}$ fertilization ${ }^{64}$. Herbicide application also caused significant decreases in root colonization and spore biomass of arbuscular mycorrhizal fungi in tropical agriculture ${ }^{65}$. Here, the managerial practices in oil palm and rubber plantations did not result in decreased mycorrhizal spore densities but resulted in lower mycorrhizal colonization and enhanced root mortality in oil palm plantations compared to other systems ${ }^{33}$. High spore abundances 
may indicate stress responses because of unsuitable environmental conditions for mycorrhizal host colonization ${ }^{33}$.

A striking result, which is in contrast to the occurrence of mycorrhizal species in temperate and boreal forest soils ${ }^{66-68}$, was an apparently low richness and abundance of mycorrhizal fungi. In temperate forests approximately 30 to $40 \%$ of the OTUs belong to mycorrhizal fungi 66,69 , whereas here only $6 \%$ could assigned to mycorrhizas. Land transformation further resulted in decreased species richness of symbiotrophic fungi in soil and, thus, obviously depleted the reservoir from which the vegetation is being colonized ${ }^{70}$. Because carbon, nitrogen, sulfur, manganese, and base cation concentrations showed a decline in the roots of rubber and oil palm trees compared to those from rain forests ${ }^{33}$, our results suggest that the impoverishment of mutualistic fungi has acute consequences for ecological functions such as plant nutrient provisioning. These findings further pinpoint the trade-off between multiple ecosystem functions and services (climate regulation, carbon storage, habitat loss) and the production of marketable goods by land transformation ${ }^{71}$.

Different tropical land use systems were clearly characterized by the presence of distinct fungal assemblages, in which significantly enriched taxa were denoted as indicator species. The concept of indicator species is useful to predict biodiversity-based ecosystem services, which is essential for sustainable agriculture ${ }^{72}$. An increase in pathogens, as observed here in managed systems, is a well-known phenomenon in monocultures composed of genetically uniform host species planted at high densities ${ }^{73}$. In oil palm plantations, we identified Fusarium oxysporum as the most abundant pathogen, supporting the idea that oil palm monoculture management fosters the proliferation of these species ${ }^{74}$. Fungi of the genus Fusarium have been described as the most destructive cause of oil palm diseases such as common spear rot in oil palms in Sumatra ${ }^{75}$, crown diseases ${ }^{76}$ and vascular wilt ${ }^{77}$, but in our 
study, no obvious disease symptoms were observed on the trees (Edy Nur, personal observation). An explanation could be the presence of Paraconiothyrium variabile, an antagonist of Fusarium oxysporum ${ }^{78-80}$. An additional common pest in oil palm plantations is Ganoderma sp., which is able to cause devastating diseases leading to great economic losses ${ }^{81,82}$. Ganoderma sp. are abundant in tropical rain forests ${ }^{83,84}$. Here, they were enriched in rain forests and jungle rubber systems but not in the intensively managed plantations.

Although monocropping systems such as oil palm plantations show decreased leaf litter input ${ }^{33,85}$, saprotrophic fungi increased. Nutrient input by fertilization, especially manure application ${ }^{33}$, may have created new ecological habitats, possibly fostering increased abundance of saprotrophic fungi. ${ }^{86}$. Furthermore, the introduction of new species such as rubber can also foster new fungal associates. For example, in rubber plantations, saprotrophic species of Leptodiscella were enriched, for which a function in degradation of rubber litter has been described ${ }^{87}$. Saprotrophic Trichoderma species were also abundant. They are known to prevent rubber trees from fungal pathogen attack and have been successfully used as pest control organisms against Rigidoporus microporus and Ganoderma pseudoferreum, two of the most important pests of rubber trees, causing white and red root $\operatorname{rot}^{88}$. Furthermore, Penicillium sp. were identified as indicator taxa in the soil of rubber plantations. Penicillium species are antagonists of plant pathogens, inducing resistance ${ }^{89}$, for example, by the production of antibiotic compounds ${ }^{90}$ or establishment of mycoparasitic interactions ${ }^{91}$. Antagonistic relationships between beneficial Penicillium species and pathogenic Fusarium species have been demonstrated in numerous studies, including in oil palms ${ }^{92-94}$. Penicillium species are also present as endophytes in the foliage and sapwood of rubber trees ${ }^{95}$ and, thereby, can contribute to limiting pathogen damage in tropical trees. Our fungal indicator network for rubber and oil palm plantations was linked to saprotrophic 
Myrothecium. Endophytic Myrothecium species, isolated from rubber, exhibit inhibitory activity against South American Leaf Blight, a disease responsible for the poor development of rubber plantations in Latin America ${ }^{96}$. Overall, these findings demonstrate that land transformation triggered shifts in fungal communities towards pathogens and antagonists. In contrast to saprotrophic and pathogenic fungi, the presence of symbiotrophic fungi in soil was strongly decreased in all types of managed systems, most likely as the result of loss of host trees and establishment of nonendemic monocultures ${ }^{19,20,37}$. This decrease was particularly evident for ectomycorrhizal species, which were absent on roots in rubber and oil plantations ${ }^{33}$ and did not appear here as indicator species in plantations. In rain forests, Scleroderma, which forms ectomycorrhizae ${ }^{97}$, was identified as an indicator taxon. Members of the genus Archaeospora, known to form arbuscular mycorrhizae ${ }^{98}$, were also identified here as indicator fungi in rain forests. Notably, fungi of the genus Oidiodendron, which form typical ericoid mycorrhizae ${ }^{99,100}$, were enriched in the rain forests and jungle rubber systems. Ericoid fungi can access organic nitrogen and thereby improve plant nitrogen nutrition under nitrogen limitation ${ }^{101}$. We suspect that this function may be important for the higher nitrogen retention observed in rain forests compared with oil palm plantations ${ }^{102}$.

\section{Conclusions}

Overall, this study demonstrates that even moderate disturbance imposed by extensive rubber cultivation in secondary rain forest resulted in changes in soil fungal community structure compared to unmanaged forests in protected areas. The most drastic changes occurred in oil palm plantations. It is clear that our analysis is limited to some extent because the functional interactions of most soil fungi in situ are still unknown and present classifications of fungal guilds are far from complete. Nevertheless, our network analysis and the identified indicator taxa reveal that land transformation causes functional shifts in fungal 
assemblages, which put the health of these systems at risk by promoting pathogenic fungi. We found corresponding changes in the abundance of antagonistic fungi, which may point towards a control of pathogenic fungi across all land use types. Here we focused on soil inhabiting fungi. It is likely that biodiversity of plant species will also result in changes of rhizosphere and root biota, which represent primary interaction sites for microbiome members ${ }^{103-105}$. In future studies, it will important to analyze the extent of microbial turnover in different niches. For sustainable land use, future studies should elucidate the factors that drive the system across the tipping point and should develop countermeasures. Because high rates of ecosystem disturbance are known to lead to extinction of all but the most disturbance-adapted species ${ }^{59}$, we had expected that land transformation would result in a drastic loss of fungal species richness. However, a general loss of fungal taxa was not observed, despite the massive biodiversity loss in plantations ${ }^{4,106}$. Instead, a massive reduction in symbiotrophic fungal species occurred, implying a loss of ecosystem provisioning functions. For example, in our oil palm plantations nitrogen losses in the run-off were higher than in the rain forests ${ }^{35}$. As the consequence, nutrient losses have to be compensated by fertilization ${ }^{107}$. Our study thus demonstrates critical links between biodiversity and ecosystem services. Increased knowledge of the impact of land use systems on fungal biodiversity is needed to use the existing agricultural land more efficiently and to balance ecological and economic goals. 


\section{References}

1. Armstrong, A. H. Tropical Rainforest Ecosystems. in International Encyclopedia of Geography: People, the Earth, Environment and Technology (eds. Richardson, D. et al.) 1-16 (John Wiley \& Sons, Ltd, 2017). doi:10.1002/9781118786352.wbieg0644

2. Gibbs, H. K. et al. Tropical forests were the primary sources of new agricultural land in the 1980s and 1990s. Proc. Natl. Acad. Sci. 107, 16732-16737 (2010).

3. Margono, B. A., Potapov, P. V., Turubanova, S., Stolle, F. \& Hansen, M. C. Primary forest cover loss in Indonesia over 2000-2012. Nat. Clim. Change 4, 730-735 (2014).

4. Drescher, J. et al. Ecological and socio-economic functions across tropical land use systems after rainforest conversion. Philos. Trans. R. Soc. B Biol. Sci. 371, 20150275 (2016).

5. Eisenhauer, N. et al. Root biomass and exudates link plant diversity with soil bacterial and fungal biomass. Sci. Rep. 7, 44641 (2017).

6. Lange, M. et al. Plant diversity increases soil microbial activity and soil carbon storage. Nat. Commun. 6, 6707 (2015).

7. Peay, K. G., Baraloto, C. \& Fine, P. V. Strong coupling of plant and fungal community structure across western Amazonian rainforests. ISME J. 7, 1852-1861 (2013).

8. Mueller, R. C. et al. Links between plant and fungal communities across a deforestation chronosequence in the Amazon rainforest. ISME J. 8, 1548-1550 (2014).

9. Barberán, A. et al. Relating belowground microbial composition to the taxonomic, phylogenetic, and functional trait distributions of trees in a tropical forest. Ecol. Lett. 18, 1397-1405 (2015).

10. Treseder, K. K. \& Lennon, J. T. Fungal Traits That Drive Ecosystem Dynamics on Land. Microbiol. Mol. Biol. Rev. MMBR 79, 243-262 (2015).

11. Větrovský, T. \& Baldrian, P. Analysis of soil fungal communities by amplicon pyrosequencing: current approaches to data analysis and the introduction of the pipeline SEED. Biol. Fertil. Soils (2013). doi:10.1007/s00374-013-0801-y

12. Moore, J. A. M., Jiang, J., Post, W. M. \& Classen, A. T. Decomposition by ectomycorrhizal fungi alters soil carbon storage in a simulation model. Ecosphere 6, $\operatorname{art29}$ (2015).

13. Martinez, D. et al. Genome, transcriptome, and secretome analysis of wood decay fungus Postia placenta supports unique mechanisms of lignocellulose conversion. Proc. Natl. Acad. Sci. 106, 1954-1959 (2009).

14. Agtmaal, M. van et al. Exploring the reservoir of potential fungal plant pathogens in agricultural soil. Appl. Soil Ecol. 121, 152-160 (2017).

15. Bender, S. F. et al. Symbiotic relationships between soil fungi and plants reduce $\mathrm{N}_{2} \mathrm{O}$ emissions from soil. ISME J. 8, 1336 (2014).

16. Tedersoo, L. et al. Global diversity and geography of soil fungi. Science 346, 12566881256688 (2014).

17. Cardoso, E. J. B. N. et al. Soil health: looking for suitable indicators. What should be considered to assess the effects of use and management on soil health? Sci. Agric. 70, 274-289 (2013).

18. Raaijmakers, J. M. \& Mazzola, M. Soil immune responses. Science 352, 1392-1393 (2016). 
19. Kerfahi, D., Tripathi, B. M., Lee, J., Edwards, D. P. \& Adams, J. M. The impact of selective-logging and forest clearance for oil palm on fungal communities in Borneo. PLOS ONE 9, e111525 (2014).

20. McGuire, K. L. et al. Responses of soil fungi to logging and oil palm agriculture in southeast Asian tropical forests. Microb. Ecol. 69, 733-747 (2015).

21. Kerfahi, D., Tripathi, B. M., Dong, K., Go, R. \& Adams, J. M. Rainforest conversion to rubber plantation may not result in lower soil diversity of bacteria, fungi, and nematodes. Microb. Ecol. 72, 359-371 (2016).

22. Mueller, R. C., Rodrigues, J. L. M., Nüsslein, K. \& Bohannan, B. J. M. Land use change in the Amazon rain forest favours generalist fungi. Funct. Ecol. 30, 1845-1853 (2016).

23. Cho, H., Kim, M., Tripathi, B. \& Adams, J. Changes in Soil Fungal Community Structure with Increasing Disturbance Frequency. Microb. Ecol. 74, 62-77 (2017).

24. Monkai, J., Hyde, K. D., Xu, J. \& Mortimer, P. E. Diversity and ecology of soil fungal communities in rubber plantations. Fungal Biol. Rev. 31, 1-11 (2017).

25. Hughes, A. C. Understanding the drivers of Southeast Asian biodiversity loss. Ecosphere 8, e01624 (2017).

26. Keenan, R. J. et al. Dynamics of global forest area: Results from the FAO Global Forest Resources Assessment 2015. For. Ecol. Manag. 352, 9-20 (2015).

27. Carlson, K. M. et al. Effect of oil palm sustainability certification on deforestation and fire in Indonesia. Proc. Natl. Acad. Sci. 201704728 (2017). doi:10.1073/pnas.1704728114

28. Marimin, Darmawan, M. A., Machfud, Islam Fajar Putra, M. P. \& Wiguna, B. Value chain analysis for green productivity improvement in the natural rubber supply chain: a case study. J. Clean. Prod. 85, 201-211 (2014).

29. Kotowska, M. M., Leuschner, C., Triadiati, T., Meriem, S. \& Hertel, D. Quantifying above- and belowground biomass carbon loss with forest conversion in tropical lowlands of Sumatra (Indonesia). Glob. Change Biol. 21, 3620-3634 (2015).

30. Barnes, A. D. et al. Direct and cascading impacts of tropical land-use change on multitrophic biodiversity. Nat. Ecol. Evol. 1, 1511-1519 (2017).

31. Kardol, P. \& De Long, J. R. How anthropogenic shifts in plant community composition alter soil food webs. F1000Research 7, 4 (2018).

32. Angers, D. A. \& Caron, J. Plant-induced changes in soil structure: Processes and feedbacks. Biogeochemistry 42, 55-72 (1998).

33. Sahner, J. et al. Degradation of root community traits as indicator for transformation of tropical lowland rain forests into oil palm and rubber plantations. PLOS ONE 10, e0138077 (2015).

34. Kubitza, C., Krishna, V. V., Urban, K., Alamsyah, Z. \& Qaim, M. Land Property Rights, Agricultural Intensification, and Deforestation in Indonesia. Ecol. Econ. 147, 312-321 (2018).

35. Allen, K., Corre, M. D., Tjoa, A. \& Veldkamp, E. Soil nitrogen-cycling responses to conversion of lowland forests to oil palm and rubber plantations in Sumatra, Indonesia. PLOS ONE 10, e0133325 (2015).

36. Meijide, A. et al. Controls of water and energy fluxes in oil palm plantations: Environmental variables and oil palm age. Agric. For. Meteorol. 239, 71-85 (2017).

37. Rembold, K., Mangopo, H., Tjitrosoedirdjo, S. S. \& Kreft, H. Plant diversity, forest dependency, and alien plant invasions in tropical agricultural landscapes. Biol. Conserv. 213, 234-242 (2017). 
38. Toju, H., Tanabe, A. S., Yamamoto, S. \& Sato, H. High-coverage ITS primers for the DNA-based identification of Ascomycetes and Basidiomycetes in environmental samples. PLOS ONE 7, e40863 (2012).

39. White, T. D. B., Lee S B \& Taylor J W. Amplification and direct sequencing of fungal ribosomal RNA Genes for phylogenetics. (1990).

40. Caporaso, J. G. et al. QIIME allows analysis of high-throughput community sequencing data. Nat. Methods 7, 335-336 (2010).

41. Martin, M. Cutadapt removes adapter sequences from high-throughput sequencing reads. EMBnet.journal 17, 10 (2011).

42. Bragg, L., Stone, G., Imelfort, M., Hugenholtz, P. \& Tyson, G. W. Fast, accurate errorcorrection of amplicon pyrosequences using Acacia. Nat. Methods 9, 425-426 (2012).

43. Edgar, R. C., Haas, B. J., Clemente, J. C., Quince, C. \& Knight, R. UCHIME improves sensitivity and speed of chimera detection. Bioinformatics 27, 2194-2200 (2011).

44. Abarenkov, K. et al. The UNITE database for molecular identification of fungi - recent updates and future perspectives: Letters. New Phytol. 186, 281-285 (2010).

45. Nilsson, R. H. et al. A Comprehensive, Automatically Updated Fungal ITS Sequence Dataset for Reference-Based Chimera Control in Environmental Sequencing Efforts. Microbes Environ. 30, 145-150 (2015).

46. McDonald, D. et al. The Biological Observation Matrix (BIOM) format or: how I learned to stop worrying and love the ome-ome. GigaScience 1, (2012).

47. Nguyen, N. H. et al. FUNGuild: An open annotation tool for parsing fungal community datasets by ecological guild. Fungal Ecol. 20, 241-248 (2016).

48. Hothorn, T. et al. Simultaneous Inference in General Parametric Models. (2017).

49. Albertsen, M., Karst, S. M., Ziegler, A. S., Kirkegaard, R. H. \& Nielsen, P. H. Back to Basics - The Influence of DNA Extraction and Primer Choice on Phylogenetic Analysis of Activated Sludge Communities. PLOS ONE 10, e0132783 (2015).

50. Oksanen, J. Package 'vegan' - Community Ecology Package, version 2.0-4. (2016).

51. Lozupone, C., Lladser, M. E., Knights, D., Stombaugh, J. \& Knight, R. UniFrac: an effective distance metric for microbial community comparison. ISME J. 5, 169-172 (2011).

52. Blüthgen, N. et al. A quantitative index of land-use intensity in grasslands: Integrating mowing, grazing and fertilization. Basic Appl. Ecol. 13, 207-220 (2012).

53. Euler, M., Krishna, V., Schwarze, S., Siregar, H. \& Qaim, M. Oil Palm Adoption, Household Welfare, and Nutrition Among Smallholder Farmers in Indonesia. World Dev. 93, 219-235 (2017).

54. Cáceres, M. D. \& Legendre, P. Associations between species and groups of sites: indices and statistical inference. Ecology 90, 3566-3574 (2009).

55. Shannon, P. Cytoscape: A Software Environment for Integrated Models of Biomolecular Interaction Networks. Genome Res. 13, 2498-2504 (2003).

56. Merico, D., Gfeller, D. \& Bader, G. D. How to visually interpret biological data using networks. Nat. Biotechnol. 27, 921-924 (2009).

57. Bouffaud, M.-L. et al. Indicator species and co-occurrence in communities of arbuscular mycorrhizal fungi at the European scale. Soil Biol. Biochem. 103, 464-470 (2016).

58. Mendes, B. et al. Fungi as environmental microbiological indicators. Water Sci. Technol. 38, (1998).

59. Miller, A. D., Roxburgh, S. H. \& Shea, K. How frequency and intensity shape diversitydisturbance relationships. Proc. Natl. Acad. Sci. 108, 5643-5648 (2011). 
60. Schneider, D. et al. Impact of lowland rainforest transformation on diversity and composition of soil prokaryotic communities in Sumatra (Indonesia). Front. Microbiol. 6, (2015).

61. Berkelmann, D. et al. How Rainforest Conversion to Agricultural Systems in Sumatra (Indonesia) Affects Active Soil Bacterial Communities. Front. Microbiol. 9, (2018).

62. Vogt, D., Tilley, J. P. \& Edmonds, R. L. Soil and plant analysis for forest ecosystem characterization. (Walter de Gruyter GmbH \& Co., KG, 2015).

63. Mendes, L. W., de Lima Brossi, M. J., Kuramae, E. E. \& Tsai, S. M. Land-use system shapes soil bacterial communities in Southeastern Amazon region. Appl. Soil Ecol. 95, 151-160 (2015).

64. Kaspari, M. et al. Biogeochemistry drives diversity in the prokaryotes, fungi, and invertebrates of a Panama forest. Ecology 98, 2019-2028 (2017).

65. Zaller, J. G., Heigl, F., Ruess, L. \& Grabmaier, A. Glyphosate herbicide affects belowground interactions between earthworms and symbiotic mycorrhizal fungi in a model ecosystem. Sci. Rep. 4, (2015).

66. Goldmann, K. et al. Divergent habitat filtering of root and soil fungal communities in temperate beech forests. Sci. Rep. 6, (2016).

67. Wubet, T. et al. Differences in Soil Fungal Communities between European Beech (Fagus sylvatica L.) Dominated Forests Are Related to Soil and Understory Vegetation. PLOS ONE 7, e47500 (2012).

68. Lindahl, B. D. \& Clemmensen, K. E. Fungal ecology in boreal forest ecosystems. in Molecular Mycorrhizal Symbiosis (ed. Martin, F.) 387-404 (John Wiley \& Sons, Inc., 2016). doi:10.1002/9781118951446.ch21

69. Bahnmann, B. et al. Effects of oak, beech and spruce on the distribution and community structure of fungi in litter and soils across a temperate forest. Soil Biol. Biochem. 119, 162-173 (2018).

70. Danielsen, L. et al. Fungal soil communities in a young transgenic poplar plantation form a rich reservoir for fungal root communities. Ecol. Evol. 2, 1935-1948 (2012).

71. Dislich, C. et al. A review of the ecosystem functions in oil palm plantations, using forests as a reference system: Ecosystem functions of oil palm versus forest. Biol. Rev. (2016). doi:10.1111/brv.12295

72. Birkhofer, K. et al. A framework to identify indicator species for ecosystem services in agricultural landscapes. Ecol. Indic. 91, 278-286 (2018).

73. McDonald, B. A. \& Stukenbrock, E. H. Rapid emergence of pathogens in agroecosystems: global threats to agricultural sustainability and food security. Philos. Trans. R. Soc. B Biol. Sci. 371, 20160026 (2016).

74. Gogbe, B. F. E. D., Diabate, S., Konan, J. N., Kablan, K. A. B. M. \& Dogbo, D. O. Oil palm Fusarium wilt distribution and incidence in Southern Region of Ivory Coast. Afr. J. Agric. Res. 12, 2895-2901 (2017).

75. Suwandi, Akino, S. \& Kondo, N. Common Spear Rot of Oil Palm in Indonesia. Plant Dis. 96, 537-543 (2012).

76. Hafizi, R., Salleh, B. \& Latiffah, Z. Morphological and molecular characterization of Fusarium solani and F. oxysporum associated with crown disease of oil palm. Braz. J. Microbiol. 44, 959-968 (2013).

77. Flood, J. A Review of Fusarium Wilt of Oil Palm Caused by Fusarium oxysporum f. sp. elaeidis. Phytopathology 96, 660-662 (2006). 
78. Prado, S., Nay, B. \& Kunz, C. Paraconiothyrium variabile, an ascomycete endophyte, suppresses mycotoxin production in the plant pathogen Fusarium oxysporum. J. Mycol. Médicale 25, e96-e97 (2015).

79. Combès, A. et al. Chemical communication between the endophytic fungus Paraconiothyrium variabile and the phytopathogen Fusarium oxysporum. PLOS ONE 7, e47313 (2012).

80. Schlatter, D., Kinkel, L., Thomashow, L., Weller, D. \& Paulitz, T. Disease Suppressive Soils: New Insights from the Soil Microbiome. Phytopathology 107, 1284-1297 (2017).

81. Ho, C.-L. et al. De novo transcriptome analyses of host-fungal interactions in oil palm (Elaeis guineensis Jacq.). BMC Genomics 17, (2016).

82. Hushiarian, R., Yusof, N. \& Dutse, S. Detection and control of Ganoderma boninense: strategies and perspectives. SpringerPlus 2, 555 (2013).

83. Yamashita, S. et al. Food web structure of the fungivorous insect community on bracket fungi in a Bornean tropical rain forest: Bornean fungivorous insect food webs. Ecol. Entomol. 40, 390-400 (2015).

84. Mohammed, C. L., Rimbawanto, A. \& Page, D. E. Management of basidiomycete rootand stem-rot diseases in oil palm, rubber and tropical hardwood plantation crops. For. Pathol. 44, 428-446 (2014).

85. Krashevska, V. et al. Micro-decomposer communities and decomposition processes in tropical lowlands as affected by land use and litter type. Oecologia 187, 255-266 (2018).

86. Arnold, A. E. et al. Fungal endophytes limit pathogen damage in a tropical tree. Proc. Natl. Acad. Sci. 100, 15649-15654 (2003).

87. Seephueak, P., Petcharat, V. \& Phongpaichit, S. Fungi associated with leaf litter of para rubber (Hevea brasiliensis). Mycology 1, 213-227 (2010).

88. McMahon, P. Effect of nutrition and soil function on pathogens of tropical tree crops. (Cumagun, C.J. (Ed.), Plant Pathology, 2012).

89. Hossain, M. M., Sultana, F., Kubota, M., Koyama, H. \& Hyakumachi, M. The plant growth-promoting fungus Penicillium simplicissimum GP17-2 induces resistance in Arabidopsis thaliana by activation of multiple defense signals. Plant Cell Physiol. 48, 1724-1736 (2007).

90. Yang, L. et al. Antifungal substances produced by Penicillium oxalicum strain PY-1potential antibiotics against plant pathogenic fungi. World J. Microbiol. Biotechnol. 24, 909-915 (2008).

91. Sempere, F. Suppression of Nigrospora oryzae (Berk. \& Broome) Petch by an aggressive mycoparasite and competitor, Penicillium oxalicum Currie \& Thom. Int. J. Food Microbiol. 122, 35-43 (2008).

92. Alam, S. S., Sakamoto, K. \& Inubushi, K. Biocontrol efficiency of Fusarium wilt diseases by a root-colonizing fungus Penicillium sp. Soil Sci. Plant Nutr. 57, 204-212 (2011).

93. Radhakrishnan, R. IAA-Producing Penicillium sp. NICS01 triggers plant growth and suppresses Fusarium sp. induced oxidative stress in sesame (Sesamum indicum L.). J. Microbiol. Biotechnol. 23, 856-863 (2013).

94. Hung, P. M., Wattanachai, P., Kasem, S. \& Poeaim, S. Efficacy of Chaetomium species as biological control agents against Phytophthora nicotianae root rot in citrus. Mycobiology 43, 288 (2015). 
95. Gazis, R. \& Chaverri, P. Diversity of fungal endophytes in leaves and stems of wild rubber trees (Hevea brasiliensis) in Peru. Fungal Ecol. 3, 240-254 (2010).

96. Rocha, A. C. S. et al. Foliar endophytic fungi from Hevea brasiliensis and their antagonism on Microcyclus ulei. Fungal Divers. 47, 75-84 (2011).

97. Mrak, T. et al. Scleroderma areolatum ectomycorrhiza on Fagus sylvatica L. Mycorrhiza 27, 283-293 (2017).

98. Garcés-Ruiz, M., Senés-Guerrero, C., Declerck, S. \& Cranenbrouck, S. Arbuscular Mycorrhizal Fungal Community Composition in Carludovica palmata, Costus scaber and Euterpe precatoria from Weathered Oil Ponds in the Ecuadorian Amazon. Front. Microbiol. 8, (2017).

99. Tian, W., Zhang, C. Q., Qiao, P. \& Milne, R. Diversity of culturable ericoid mycorrhizal fungi of Rhododendron decorum in Yunnan, China. Mycologia 103, 703-709 (2011).

100. Rice, A. V. \& Currah, R. S. Oidiodendron: A survey of the named species and related anamorphs of Myxotrichum. Stud. Mycol. 53, 83-120 (2005).

101. Finlay, R. D. Ecological aspects of mycorrhizal symbiosis: with special emphasis on the functional diversity of interactions involving the extraradical mycelium. J. Exp. Bot. 59, 1115-1126 (2008).

102. Templer, P. H., Silver, W. L., Pett-Ridge, J., M. DeAngelis, K. \& Firestone, M. K. PLANT AND MICROBIAL CONTROLS ON NITROGEN RETENTION AND LOSS IN A HUMID TROPICAL FOREST. Ecology 89, 3030-3040 (2008).

103. Fonseca, J. P. et al. Contrasting the microbiomes from forest rhizosphere and deeper bulk soil from an Amazon rainforest reserve. Gene 642, 389-397 (2018).

104. Reinhold-Hurek, B., Bünger, W., Burbano, C. S., Sabale, M. \& Hurek, T. Roots Shaping Their Microbiome: Global Hotspots for Microbial Activity. Annu. Rev. Phytopathol. 53, 403-424 (2015).

105. Meier, I. C., Pritchard, S. G., Brzostek, E. R., McCormack, M. L. \& Phillips, R. P. The rhizosphere and hyphosphere differ in their impacts on carbon and nitrogen cycling in forests exposed to elevated $\mathrm{CO}_{2}$. New Phytol. 205, 1164-1174 (2015).

106. Barnes, A. D. et al. Consequences of tropical land use for multitrophic biodiversity and ecosystem functioning. Nat. Commun. 5, 5351 (2014).

107. Kurniawan, S., Corre, M. D., Utami, S. R. \& Veldkamp, E. Soil Biochemical Properties and Nutrient Leaching from Smallholder Oil Palm Plantations, Sumatra-Indonesia. AGRIVITA J. Agric. Sci. 40, 257-266 (2018). 


\section{Author contributions}

NB: conducted data analyses and wrote the manuscript, DS: conducted bioinformatics analyses on the sequence data and analyzed the data set, JS: collected samples and calculated the land use index, JB: conducted bioinformatics analyses, NE: collected samples, HB: administrative local support in Jambi, BI: provided comments on the manuscript, SWB: contributed expertise in arbuscular mycorrhizal fungi, MQ: provided data about land use management, RD: supervised and contributed to the analyses of fungal metacommunity data set, AP: conceived the project, conducted data analyses and wrote the final manuscript, All: contributed to, read and commented on the final manuscript.

\section{Additional Information}

Accession code: The raw ITS rDNA sequences have been deposited in the National Center for Biotechnology Information (NCBI) Sequence Read Archive (SRA) under study accession number SRP134264 (Bioproject number PRJNA437389). Supplementary information accompanies this paper at http://www.nature.com/srep. Competing financial interests: The authors declare no competing financial interests. This study was funded by the Deutsche Forschungsgemeinschaft (DFG, German Research Foundation) - project number 192626868

- SFB 990 in the framework of the collaborative German - Indonesian research project CRC990． 


\section{Tables}

Table 1. OTU richness and diversity indices of fungal taxa in rain forests and jungle rubber, monospecific rubber and oil palm plantations. Rarefied samples (1229 sequences) were used for the analyses. Significant differences between means of groups at $p \leq 0.05$ are indicated by different letters $(n=30)$. OTU richness $=$ calculation for observed species at a sequence depth of 1229 sequence reads. To test for significant differences between land use systems, linear mixed effect models and post hoc (Tukey's) tests were applied, and differences at $p \leq$ 0.05 are indicated by different letters in columns. Michaelis-Menten fit and Chao1 were used to estimate the maximum species richness.

\begin{tabular}{llllll}
\hline Land use system & $\begin{array}{l}\text { Observed } \\
\text { OTU richness }\end{array}$ & $\begin{array}{l}\text { Michaelis } \\
\text { Menten Fit }\end{array}$ & Chao1 & Shannon & Simpson \\
\hline Rainforest & $344 \pm 90 \mathrm{a}$ & $581 \pm 192 \mathrm{a}$ & $539 \pm 194 \mathrm{a}$ & $7.20 \pm 0.79 \mathrm{a}$ & $0.980 \pm 0.015 \mathrm{a}$ \\
Jungle Rubber & $441 \pm 18 \mathrm{~b}$ & $804 \pm 40 \mathrm{~b}$ & $702 \pm 57 \mathrm{a}$ & $7.93 \pm 0.14 \mathrm{~b}$ & $0.992 \pm 0.002 \mathrm{a}$ \\
Rubber & $394 \pm 45 \mathrm{ab}$ & $698 \pm 118 \mathrm{ab}$ & $621 \pm 101 \mathrm{a}$ & $7.59 \pm 0.24 \mathrm{a}$ & $0.988 \pm 0.003 \mathrm{a}$ \\
Oil palm & $375 \pm 46 \mathrm{ab}$ & $664 \pm 135 \mathrm{ab}$ & $590 \pm 123 \mathrm{a}$ & $7.44 \pm 0.35 \mathrm{ab}$ & $0.985 \pm 0.008 \mathrm{a}$ \\
\hline
\end{tabular}

Table 2. Comparison of relative abundances (\%) of fungal phyla. The number of sequence reads of a taxonomic group was expressed as a proportion of the total number of sequence reads (1229) of each plot. For statistical analyses, generalized linear mixed effect models with landscape as a random effect were performed. Significant differences at $p \leq 0.05$ between means of groups are indicated by letters $(n=30)$.

\begin{tabular}{lllll}
\hline Phylum & Rainforest & Jungle rubber & Rubber plantation & Oil palm plantation \\
\hline Ascomycota & $74.5 \pm 5.2 \mathrm{a}$ & $73.9 \pm 12.9 \mathrm{a}$ & $83.3 \pm 8.7 \mathrm{~b}$ & $88.8 \pm 1.9 \mathrm{c}$ \\
Basidiomycota & $14.0 \pm 5.2 \mathrm{~d}$ & $12.5 \pm 7.2 \mathrm{c}$ & $5.0 \pm 2.4 \mathrm{~b}$ & $4.2 \pm 1.2 \mathrm{a}$ \\
Glomeromycota & $0.4 \pm 0.5 \mathrm{a}$ & $0.7 \pm 0.8 \mathrm{~b}$ & $0.3 \pm 0.2 \mathrm{a}$ & $0.2 \pm 0.2 \mathrm{a}$ \\
Chytridiomycota & $0.2 \pm 0.2 \mathrm{a}$ & $0.2 \pm 0.2 \mathrm{a}$ & $0.3 \pm 0.2 \mathrm{a}$ & $0.2 \pm 0.2 \mathrm{a}$ \\
Zygomycota & $1.5 \pm 0.8 \mathrm{~b}$ & $3.0 \pm 3.4 \mathrm{c}$ & $1.4 \pm 2.0 \mathrm{~b}$ & $0.7 \pm 0.6 \mathrm{a}$ \\
Unidentified fungi & $9.5 \pm 1.7 \mathrm{~b}$ & $9.6 \pm 3.9 \mathrm{~b}$ & $9.7 \pm 5.6 \mathrm{~b}$ & $6.0 \pm 1.7 \mathrm{a}$ \\
\hline
\end{tabular}




\section{Figures}

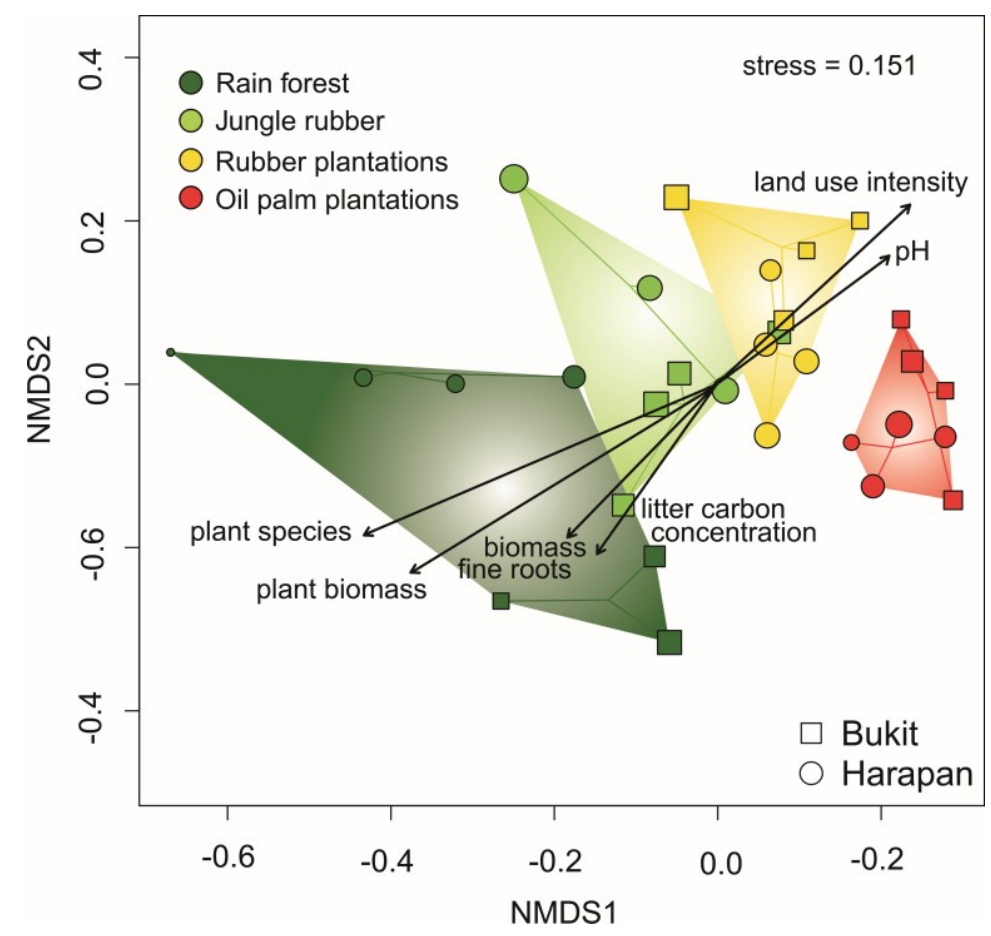

Figure 1. Nonmetric multidimensional scaling (NMDS) of fungal OTU communities. Three samples per plot were rarified to 1229 sequences and pooled. Significant correlations of biotic and abiotic variables with fungal communities are shown by black arrows ( $p \leq 0.05$ ). Sizes of symbols (squares and circles) correspond to the number of OTUs found in each plot, with a minimum of 172 OTUs and a maximum of 468 OTUs. Data for plant species and plant biomass were taken from Drescher et al., 2015. 


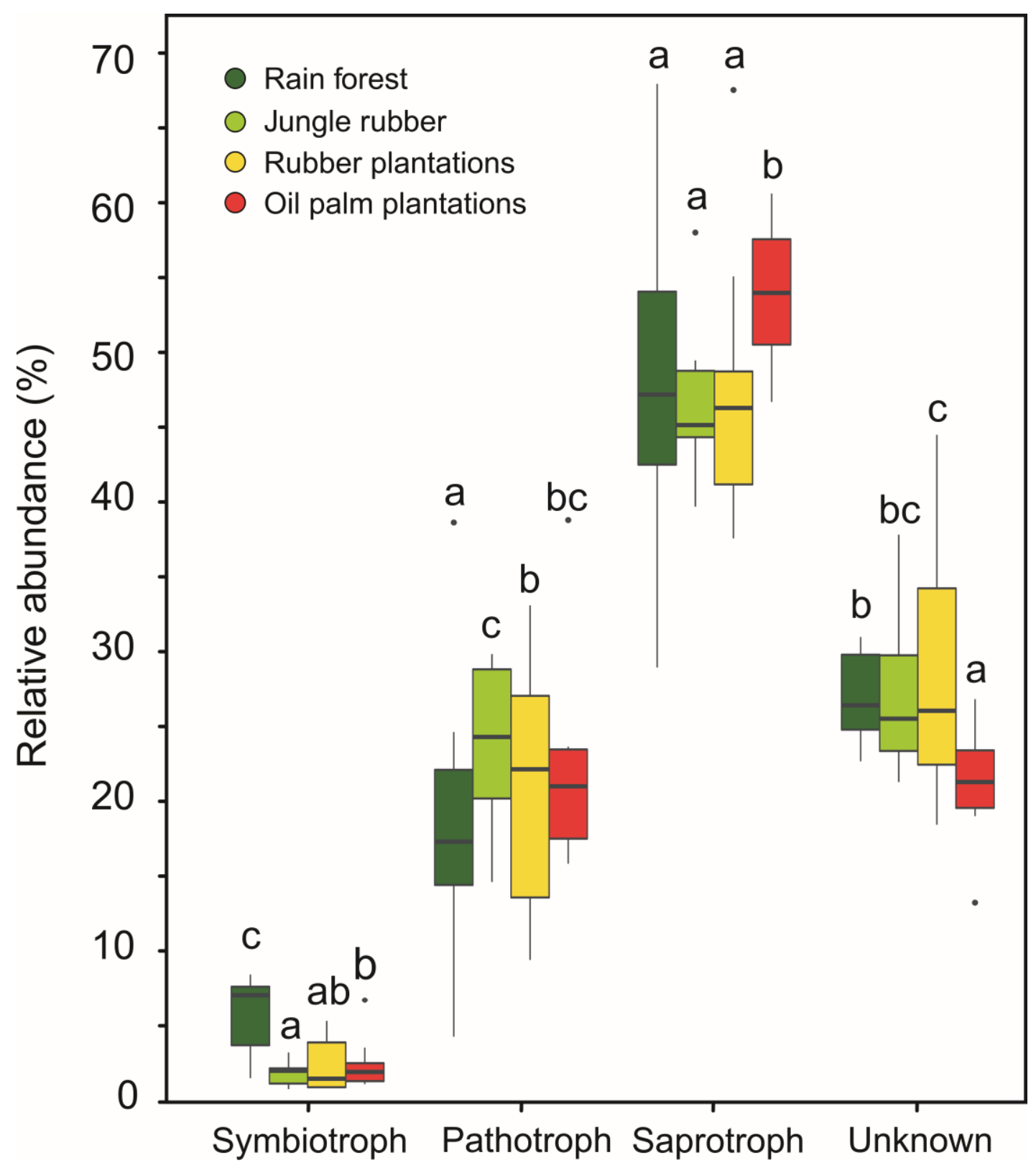

Figure 2. Relative abundance of symbiotrophic, pathotrophic, saprotrophic and unknown fungi in four land use systems. Box-and-whisker plots indicate the range of the data; the horizontal lines, the median; and the dots, outliers. Generalized linear mixed effect models were fit, and post hoc (Tukey's) tests revealed significant differences at $p \leq 0.05$. Significant differences are indicated by different letters $(p \leq 0.05, n=30)$. 

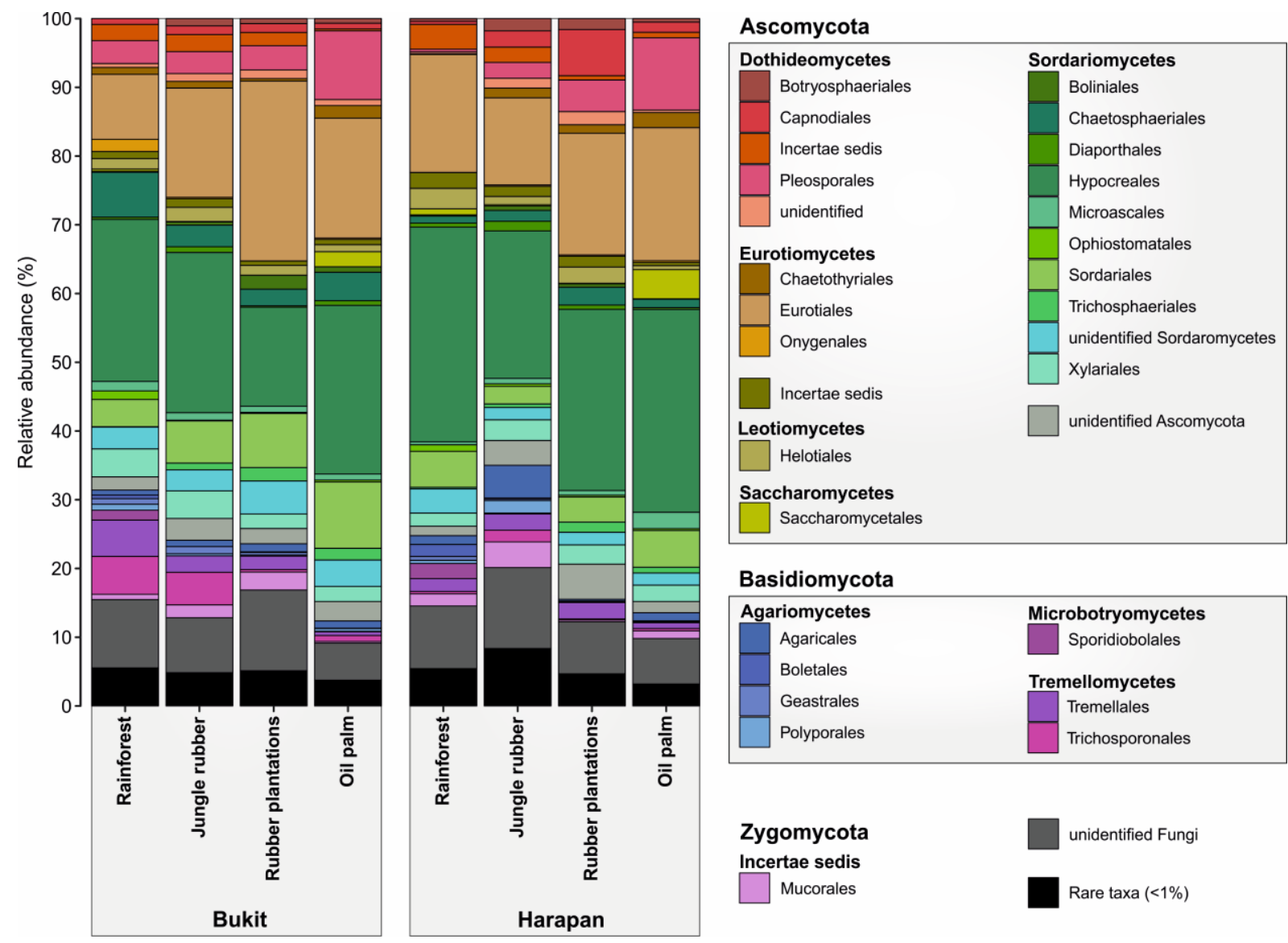

Basidiomycota

\begin{tabular}{|c|c|}
\hline Agariomycetes & Microbotryomycetes \\
\hline Agaricales & Sporidiobolales \\
\hline Boletales & Tremellomycetes \\
\hline Geastrales & Tremellales \\
\hline Polyporales & Trichosporonales \\
\hline
\end{tabular}

Zygomycota
Incertae sedis
$\square \quad$ Mucorales

unidentified Fungi

Mucorales

Rare taxa $(<1 \%)$

Figure 3. Fungal community composition on order level based on relative abundances separated by landscape and land use system. Orders with lower abundance than $1 \%$ in any land use system were summarized as artificial group "Rare taxa". 


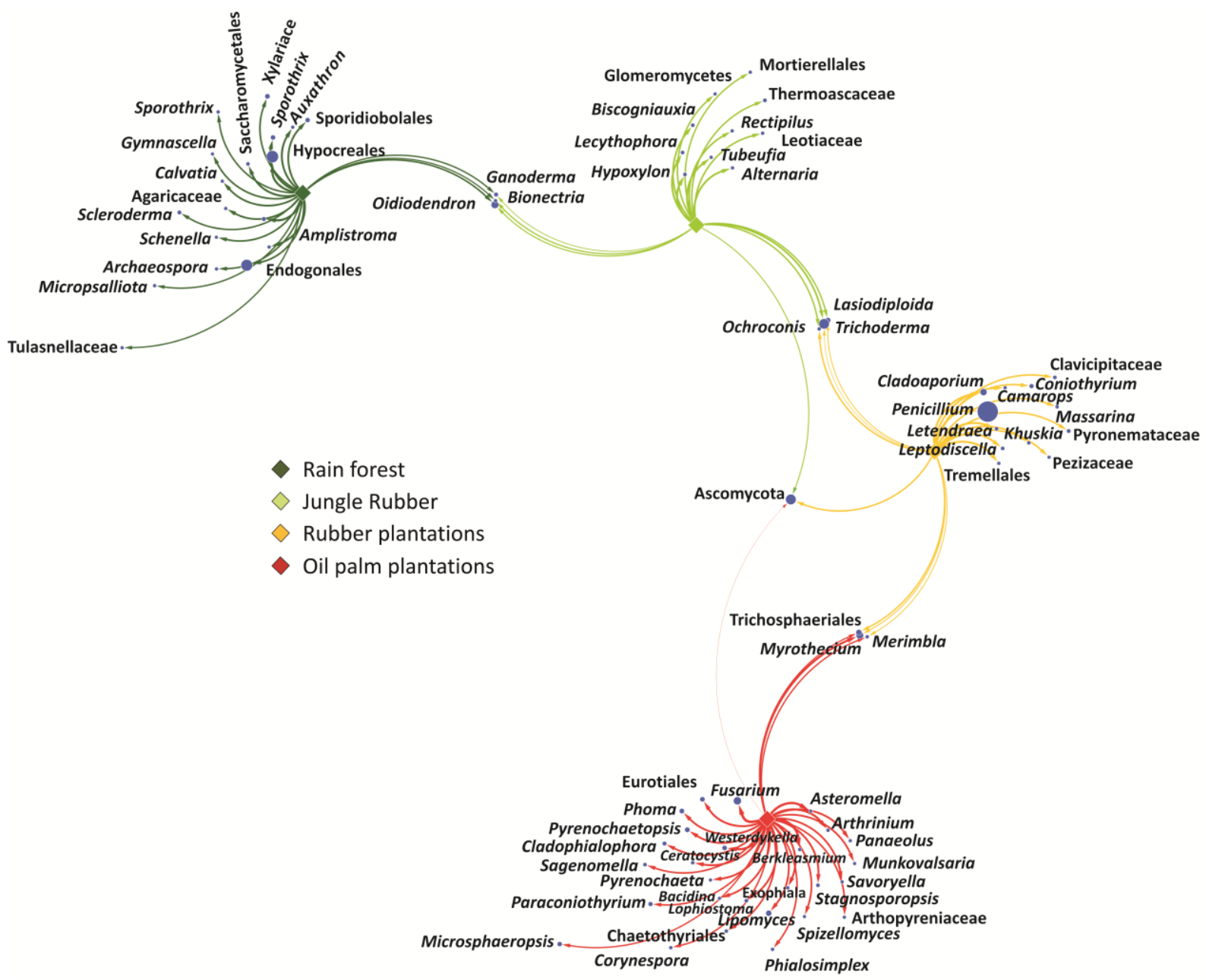

Figure 4. Association network of significantly abundant soil fungi in different land use systems (multipatt function in indicspecies package in $R$, de Cáceres et al., 2010). Node sizes represent the average relative abundance of OTUs in the data sets. Edges represent the association patterns of individual OTUs with the land use systems, and their lengths show the weight of the associations (edge-weighted, spring-embedded layout). The association strength of significant genera is indicated by different edge lengths varying between 0.09 and 0.79 . 